ALEXANDRE FRAGOSO MACHADO

\title{
O USO DA MARCA SOB A ÓTICA DA INTEGRIDADE
}

Dissertação apresentada à Faculdade de Direito da Universidade de São Paulo para obtenção do título de Mestre em Direito Comercial, sob orientação do Prof. ${ }^{\circ}$ Dr. Newton Silveira.

Faculdade de Direito da Universidade de São Paulo Departamento de Direito Comercial

São Paulo

2013 
FOLHA DE APROVAÇÃO:

Professor Orientador: Prof. ${ }^{\circ}$ Dr. Newton Silveira 


\section{Agradecimentos:}

Sou profundamente agradecido ao Prof. ${ }^{\circ}$ Newton Silveira por essa oportunidade. A caminhada até aqui foi difícil por uma série de aspectos, incluindo meu temporário desencontro enquanto aluno. Entretanto, o Prof. ${ }^{\circ}$ Newton, com seu brilhantismo, sutileza e elegância, exigiu de mim o que era necessário. Obrigado, professor. Agradeço também aos amigos, colegas advogados(as) e colegas de turma, que durante esse processo, me apoiaram e me ajudaram a enxergar o caminho certo. Sou grato também aos professores do curso de pós-graduação dessa faculdade que me aceitaram como seu aluno e me brindaram com aulas inesquecíveis. 
Dedico esse trabalho aos amores da minha vida, Juliana e Gabriela, que sempre me incentivam e me fazem sentir o melhor em tudo. Acordo, vivo e durmo pensando nelas. 


\section{RESUMO}

O presente estudo tem como objetivo analisar os efeitos do uso da marca pelo titular ou por terceiros sob a ótica da integridade. $\mathrm{O}$ uso da marca traz consequências negativas ao próprio signo no que tange à sua integridade material, causando o desgaste da sua distinção entre marcas de concorrentes, o que faz diminuir a distância distintiva entre os sinais de uma mesma atividade econômica ou afins. Além disso, o uso da marca também pode causar a perda completa de sua unicidade, corpo distintivo da marca, chegando, às vezes, à vulgarização da mesma, tornando-se res communis omnium. Do outro lado, a integridade material da marca pode passar por processos positivos que fortalecem o seu corpo distintivo. O uso da marca com sucesso faz aumentar sua fama perante o mercado e consumidores, diferenciando-a das demais e sendo alçada ao posto de marca famosa. A fama através do uso impulsiona marcas ordinárias ao status de marcas notoriamente conhecidas ou marcas de alto renome. Ambas representam degraus superiores de integridade material em relação às marcas que são ordinariamente protegidas dentro de suas atividades comerciais. Além disso, apesar do direito de uso exclusivo oferecido às marcas registradas, tal direito não é absoluto. Ou seja, mesmo ocorrendo usos desautorizados de marcas de terceiros que ocasionem alterações na integridade material das mesmas, há usos considerados permitidos pela legislação e jurisprudência. Dessa forma, pretende-se demonstrar que o uso da marca é o fio condutor desses fenômenos.

\section{Palavras-chave:}

Propriedade Intelectual - Marca - Uso - Integridade - Domínio comum - Distintividade Distinção - Reputação. 


\begin{abstract}
This paper aims to analyze the effects of the use of the trademark by the owner or by third parties from the perspective of the integrity. The use of the trademark brings negative consequences to the sign itself with respect to its material integrity, causing lack of its distinctiveness among competing marks, which slims the distinctive distance between the signs of the same or related economic field. Furthermore, the use of the trademark can also cause the complete loss of its uniqueness, distinctive body of the mark, reaching sometimes the vulgarization of the same, becoming res communis omnium. On the other hand, the material integrity of the mark can undergo positive processes that enhance its distinctive body. The successful use of the mark increases its fame before the market and consumers, differentiating it from others and being raised to a level of a famous mark. The fame through use elevates the ordinary marks to the status of well-known marks or trademarks of high repute. Both represent upper rungs of material integrity towards marks that are ordinarily protected within their fields of activities. Moreover, despite the right of exclusive use offered to registered marks, such right is not absolute. That is, even occurring unauthorized uses of trademarks by third parties which cause changes in the material integrity of the same, there are uses considered permitted by law and jurisprudence. Thus, this paper intends to demonstrate that the use of the mark is the common thread of these phenomena.
\end{abstract}

\title{
Key words:
}

Intellectual Property - Trademark - Use - Uniqueness - Public domain - Distinctiveness Distinction - Reputation 


\section{SUMÁRIO}

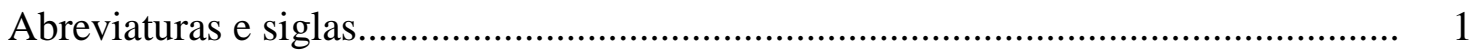

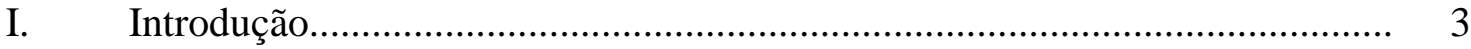

1. Tema a ser desenvolvido........................................................................ 3

2. Justificativa da escolha do tema........................................................... 8

3. Principais questões a serem abordadas................................................. 8

\section{Capítulo I}

\section{NOTAS SOBRE DIREITOS REAIS E MARCA}

1. Considerações introdutórias sobre posse..................................................... 9

2. Considerações introdutórias sobre propriedade............................................ 14

3. Considerações introdutórias sobre usucapião............................................ 16

4. Considerações introdutórias sobre o direito de uso....................................... 16

4.1. O uso como fator de concorrência........................................................ 17

5. Natureza jurídica da marca..................................................................... 20

$5.1 \quad$ O direito de propriedade sobre a marca............................................ 22

5.2 Críticas à natureza de propriedade..................................................... 32

\section{Capítulo II \\ AS NOÇÕES DE INTEGRIDADE}

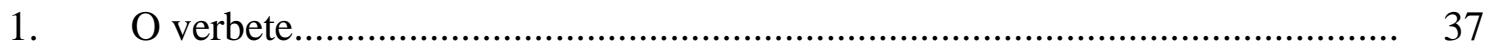

2. A integridade enquanto valor moral e ético................................................ 39

3. A integridade, Schechter e a marca............................................................. 41

\section{Capítulo III}

\section{A MARCA}

1. Evolução histórica nas sociedades............................................................... 44

2. Definições legislativa e doutrinária........................................................... 49

2.1. Definição legislativa.................................................................... 49

2.2. Definição doutrinária................................................................... 53

3. Funções de uma marca............................................................................ 57 
3.1. Considerações gerais....................................................................... 57

3.2. Função de determinação da origem................................................... 59

3.3. Função distintiva............................................................................ 61

3.4. Função econômica.......................................................................... 63

3.5. Função informativa......................................................................... 66

\section{Capítulo IV}

\section{OS DIREITOS SOBRE A MARCA}

1. O sistema de proteção da marca.................................................................... 68

1.1. O sistema atributivo de direitos.......................................................... 69

1.1.1. O processo administrativo de registro de marca............................ 70

1.2. O uso como formador do direito.........................................................

2. Direito de uso exclusivo........................................................................... 74

2.1. Os limites ao direito de uso exclusivo...................................................... 76

2.1.1. O princípio da especialidade.................................................... 76

2.1.1.1. A exceção ao princípio da especialidade......... 79

2.1.2. O princípio da territorialidade.................................................. 80

2.1.2.1. A exceção ao princípio da territorialidade................... 80

2.1.3. As hipóteses de uso legítimo de marca de terceiro................... 81

3. Demais direitos sobre a marca.................................................................... 82

3.1. Direito de dispor da marca.............................................................. 82

3.2. Direito de licenciar a marca............................................................... 83

3.3. Direito de zelar pela integridade material e moral.............................. 86

\section{Capítulo V}

\section{O USO E O SISTEMA DE PROPRIEDADE INTELECTUAL}

1. Considerações gerais.................................................................................. 88

2. A lógica do sistema.................................................................................. 90

3. O uso da marca como obrigação do titular.......................................................... 92

3.1. O desuso da marca......................................................................... 95

4. O uso da marca como faculdade do titular................................................... 100 


\section{Capítulo VI}

\section{O USO E A INTEGRIDADE DA MARCA}

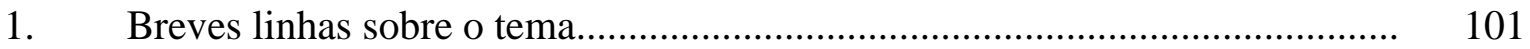

2.. $\quad$ A integridade moral do titular.................................................................. 106

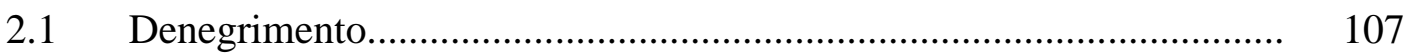

3. A integridade da marca........................................................................ 110

3.1 A integridade material.................................................................. 111

3.1.1 A distintividade................................................................ 112

3.1.1.1 As “apostilas" aplicadas pelo INPI............................. 119

3.1.1.2 Palavras de idiomas estrangeiros............................... 122

3.1.1.3 Jurisprudência comentada.......................................... 124

(a) Caso LAMAC........................................ 124

(b) Caso TICKET ........................................... 125

(c) Caso EBONY ............................................ 126

(d) Caso FRUT................................................ 126

3.1.2 “Os caminhos da distintividade"............................................ 127

3.1.2.1 A aquisição de distintividade pelo uso.......................... 127

3.1.2.2 A vulgarização de uma marca...................................... 132

3.1.2.2.1. Os efeitos da vulgarização................. 140

3.1.3 A distinção........................................................................... 145

3.1.3.1 A obtenção de exclusividade............................. 146

3.1.3.2 A marca ordinária.............................................. $\quad 148$

3.1.3.3 A marca notoriamente conhecida.................... 150

3.1.3.4 A marca de alto renome.................................... 153

3.1.3.4.1 Considerações gerais e históricas....... 153

3.1.3.4.2 Considerações doutrinárias................. 158

3.1.3.5 A diluição da exclusividade............................... 160

3.1.3.6 A teoria da distância......................................... 165

3.2 Os limites (Fair use) ...................................................................... 169

3.2.1 Liberdade de expressão......................................................... 170

3.2.1.2 Direito à crítica............................................. 175

3.2.1.3 Propaganda comparativa................................. 176

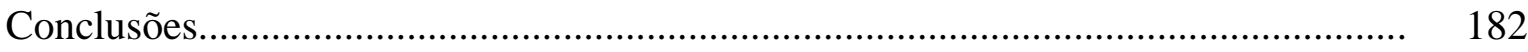


Referências Bibliográficas........................................................................................ 190 


\section{Abreviaturas e siglas}

ABPI

art.

Apud

BIRPI

Câm.

Cap.

CDC

CC

cit.

Cf.

CF

Conv.

Coord.

CPC

CPI

CUP

Des.

e.g.

et al.

i.e.

FDUSP Faculdade de Direito da Universidade de São Paulo

IASP

INPI

LPI

Min.

OMC

ONU

OMPI

Op. cit.

p.

p. ex.

pp.

Associação Brasileira da Propriedade Intelectual

Artigo

Citação da citação

Câmara

Capítulo

Lei $\mathrm{n}^{\circ}$ 8.078/90 (Código de Defesa do Consumidor)

Lei $n^{\circ}$ 10.406/2002 (Código Civil)

citado

Conforme

Convocado(a)

Coordenador

Código de Processo Civil

Desembargador(a)

exempli gratia (por exemplo)

et alii (e outros)

id est (isto é)

Instituto dos Advogados de São Paulo

Instituto Nacional da Propriedade Industrial

Lei ${ }^{\circ}$ 9.279/96 (Lei da Propriedade Industrial)

Ministro

Organização Mundial do Comércio

Organização das Nações Unidas

Organização Mundial da Propriedade Intelectual

opere citatum (citado acima)

página

por exemplo

páginas
Escritório Internacional Unificado pela Proteção da Propriedade Intelectual

Constituição Federal da República Federativa do Brasil (05/10/1988)

Lei $\mathrm{n}^{\circ}$ 5.772/71 (antigo Código da Propriedade Industrial)

Convenção da União de Paris para Proteção da Propriedade Industrial. 
RABPI Revista da Associação Brasileira da Propriedade Intelectual

Rel. Relator

REsp Recurso Especial

RExt Recurso Extraordinário

RPI Revista da Propriedade Industrial

STF Supremo Tribunal Federal

STJ Superior Tribunal de Justiça

T. Turma

t. tomo

Tit. Título

TJPR Tribunal de Justiça do Estado do Paraná

TJRJ Tribunal de Justiça do Estado do Rio de Janeiro

TJSP Tribunal de Justiça do Estado de São Paulo

TFR antigo Tribunal Federal de Recursos

TRF Tribunal Regional Federal

trad. Tradução/traduzido

TRIPs Acordo sobre Aspectos dos Direitos da Propriedade Intelectual relacionados ao Comércio

USPTO United States Patent and Trademark Office - o INPI norte-americano. 


\section{INTRODUÇÃO}

\section{Tema a ser desenvolvido}

O direito de uso e a Propriedade Intelectual sempre estiveram unidos pelas imediatas ações e reações causadas nos seus institutos jurídicos e nas relações de concorrência. O que se tem visto até aqui, sem dúvida, tem trazido vasto conhecimento para os fins do estudo da Propriedade Intelectual como ramo quase autônomo do Direito. Todavia, o instituto do uso tem sido limitadamente estudado como um foco de direito garantido aos possuidores de coisas tangíveis, sendo que, no âmbito da Propriedade Intelectual, o uso tem merecido papel tímido na doutrina, apesar da forte presença em quase todos os acontecimentos na vida empresarial dos titulares.

A prática concorrencial demonstra que tanto as empresas como os consumidores têm predileção pelas marcas que, de algum modo, fazem alusão quase ou imediata ao produto ou serviço, visto que é forçosa uma maior identificação com o mesmo por ambas as partes, facilitando muitas vezes o convencimento do consumidor para adquirir o produto e os interesses da empresa em vendê-lo.

Sob o ponto de vista econômico, a questão da escolha de um sinal por titulares para distinguirem seus negócios é das tarefas mais relevantes para aqueles que buscam vantagem concorrencial e almejam ser identificados com facilidade pelo público consumidor. Apesar do envolvimento emocional dos agentes econômicos durante o processo de escolha dos sinais que irão distinguir suas empresas (e.g. homenagem ao filho, gosto musical e sensações com experiências pessoais), muitas dessas escolhas poderiam ser mais eficientes, se os criadores ${ }^{1} 2$ desses sinais levassem em consideração alguns pontos básicos da Propriedade Intelectual.

\footnotetext{
${ }^{1}$ Há criatividade no processo idealizador de um sinal distintivo e a depender da constituição do sinal em si, há também originalidade absoluta para os fins de proteção por Direito de Autor? Isso significa dizer que há proteção autoral pela criação de marcas?

${ }^{2}$ SILVEIRA, Newton: Licença de Uso de Marca e Outros Sinais Distintivos. São Paulo: Saraiva, 1984. p. 15: "Muito embora tais sinais não constituam obras do espírito (como as invenções e obras artísticas), estão em estreita ligação com tal tipo de atividade, sendo por isso tutelados (se o sinal, em si, contém o resultado direto da atividade criadora, podendo ser considerado, p. ex., uma obra de desenho, poderá receber a tutela mais ampla dos direitos de autor). Não é condição, entretanto, para receber a tutela da lei como sinal identificador, que seja ele uma obra do espirito".
} 
No entanto, por mais que esse hábito alcance resultados junto ao mercado, o uso de marcas pouco distintivas dificulta sua identificação entre os concorrentes, denotando a fraqueza dos direitos garantidos ao titular. Conseqüentemente, tais marcas estão mais suscetíveis à reprodução ou imitação por terceiros, pois é mais barato copiar. ${ }^{3}$ Ademais, marcas pouco distintivas, de acordo com a doutrina e jurisprudência, possuem mais chance de conviver entre si, decorrendo daí uma maior dificuldade para manutenção da integridade material desse tipo de marca.

A distintividade, portanto, é elemento importante para a análise da integridade material da marca, pois de acordo com Newton SILVEIRA, a natureza da marca decorre de sua finalidade. Assim, o sinal deve ter capacidade distintiva. O sinal, de acordo com o autor, não é o produto, acresce-se a ele. ${ }^{4}$

Para efeitos ilustrativos, imagine-se a marca de queijo GOSTBOM. A finalidade do produto com essa designação é a de oferecer paladar gostoso a produtos alimentícios. Dessa forma, a marca GOSTBOM nada mais faz do que sugerir e quase descrever uma característica própria do produto. Ora, qualquer outro produto alimentício tem a mesma função, de sorte que muitas outras marcas certamente teriam composições semelhantes e dificilmente seriam impedidas juridicamente de uso.

Sob o ponto de vista da formação linguística das marcas, a Semiótica exerce relevante papel na análise das mutações dos signos. No dizer de Umberto ECO, “[A] palavra remete diretamente ao conceito mental e indiretamente à multiplicidade de objetos por ele representados". 5 Essa multiplicidade pode ser interpretada como pelas formas de utilização de um signo como marca. Ao longo do tempo e ainda pelo uso por seu titular ou por terceiros, os signos experimentam variações em seu poder distintivo, causando efeitos positivos ou negativos.

\footnotetext{
${ }^{3}$ Conforme afirmam Roger D. Blair e Thomas F. Cotter, citados por Cláudio Roberto Barbosa, “[c]opiar uma invenção de um terceiro custa consideravelmente menos que o desenvolvimento de um novo produto, mesmo se considerado o custo de engenharia reversa inevitavelmente necessário para a cópia. Cf. BARBOSA, Cláudio. Propriedade Intelectual. Introdução à propriedade intelectual como informação. São Paulo: Campus Jurídicos, 2009. p. 11 (BLAIR, Roger D.; COTTER, Thomas F: Intellectual property Economic and legal dimensions of rigths and remedies. New York: Cambridge, 2005, p. 14).

${ }^{4}$ SILVEIRA, Newton. Curso de Propriedade Industrial. São Paulo: Revista dos Tribunais, 1987. p. 19.

${ }^{5}$ ECO, Umberto. O signo. $6{ }^{\text {a }}$ Ed. Editorial Presença: Bacarena-PT, 2004. pp. 114/115.
} 
Nesse sentido, Carlos Henrique de Carvalho FRÓES anota que a importância da marca, qualquer que seja a sua forma, pode ser ilustrada por uma frase tirada de uma das obras imortais de William Shakespeare: "[M]uito está em um nome: por muito que chamássemos uma rosa por qualquer outro nome, cheiraria menos doce”. Continua o autor afirmando que o poder de sugestão da marca é imenso, que, no dizer de Albert CHAVANNE e Jean-Jacques BURST, o poder de sugestão é "parte do nosso meio ambiente e até mesmo nosso subconsciente". ${ }^{6}$

Com o fim de proteger seu patrimônio, o titular da marca precisará estar pronto para encampar as medidas cabíveis de cessação do uso de sua marca por terceiros, concorrentes ou não, quando esse prejudicar a integridade material de sua marca ou sua reputação. Uma consequiência é o enfraquecimento da distinção de sua marca e nesse sentido, Denis Borges BARBOSA comenta que, quando características de uma marca notória são identificadas pelos consumidores como exclusivas daquela marca, se tais características passam a ser utilizadas por competidores da mesma categoria, a habilidade dessas características de individualizar a marca é enfraquecida, talvez ao ponto de serem destruídas. $^{7}$

Note-se que o comentário acima traz apenas um aspecto da utilização indevida da marca por terceiros. É crucial considerar os fenômenos dessa utilização e seus efeitos. A utilização indevida de uma marca é capaz de gerar a diminuição da sua integridade material, expondo-a a consequências indesejáveis ao titular da mesma.

Em rápidas linhas, resume-se o exemplo da marca utilizada à exaustão pelo titular e pelo público de modo a fazer-se identificar como o próprio produto ou seu gênero. Está-se diante do processo de degenerescência da marca, ou perda do seu poder distintivo. Como exemplos, citam-se as marcas vulgarizadas ISOPOR e CELOPHANE. Denis BARBOSA ensina que o excesso de uso do signo em face do designado cria uma inflação

\footnotetext{
${ }^{6}$ FRÓES, Carlos Henrique de Carvalho. Marca: Aquisição de distintividade e degenerescência. In: SANTOS, Manoel J. Pereira dos e JABUR, Wilson Pinheiro (Orgs.). In Sinais Distintivos e Tutela Judicial e Administrativa. Série GVLaw. São Paulo: Saraiva, 2007. p. 84. Do original Shakespeare: [M] uch is in a name: many that we call a rose under any other name would smell less sweet". Do original de CHAVANNE e BURST: "If]ait partie de notre environnement et même de notre subconscient".

${ }^{7}$ BARBOSA, Denis. Proteção das Marcas. Uma perspectiva semiológica. Rio de Janeiro: Lumen Juris, 2008. p. 153.
} 
significativa e erode o poder de identificação. ${ }^{8}$ No presente estudo, apresentar-se-á que esse poder de identificação consiste na própria integridade material da marca.

Como outro fenômeno de influência sobre a integridade da marca, o uso indevido, pulverizando o feixe de brilho emanado pela marca em relação ao seu mercado, acarreta o desgaste do poder distintivo da marca. E no caso de marcas com certa fama, tal uso indevido enfraquece o poder identificador da marca famosa. Diluição, nas palavras de Filipe Fonteles CABRAL, consiste em uma "[o]fensa à integridade de um signo distintivo, seja moral ou material, por um agente que não necessariamente compete com o titular do sinal. O efeito da diluição de marca é a diminuição do poder de venda do sinal distintivo, seja pela lesão à sua unicidade, seja pela ofensa à sua reputação". 9

Tais fenômenos propiciam a diminuição da integridade material da marca que, enfraquecida em sua distintividade e distinção, perde valor econômico, diminuindo o poder de exclusão de terceiros. O valor da marca não é, no caso, o que resulta do prestígio de uma marca de luxo, mas a capacidade de imprimir, entre marcas relativas a mercados correlatos, uma posição claramente singular, à luz do consumidor. Assim é que marcas como IBM e COCA-COLA, sem expressarem luxo ou prestígio, têm alto valor como signo, por sua capacidade de diferenciação. ${ }^{10}$

Por outro lado, em um movimento positivo de distintividade, se um elemento de uso comum, descritivo ou genérico passa a ser utilizado por um titular a ponto dele ser interpretado pelo mercado como indicativo de procedência daquele titular, tem-se o processo de aquisição de distintividade pelo uso (secondary meaning). A marca AMERICAN AIRLINES é um exemplo desse processo.

A integridade material de uma marca, portanto, diz respeito à sua composição em todos os sentidos. Como exemplo metafórico, um tijolo pode ser quebrado ou rachado

\footnotetext{
${ }^{8}$ BARBOSA, Denis. Proteção das marcas... Op. cit. p. 194.

${ }^{9}$ CABRAL, Filipe Fonteles. Diluição de marca: Uma teoria defensiva ou ofensiva? In RABPI v. 58, Rio de Janeiro: ABPI, mai/jun 2002, p. 28.

${ }^{10}$ BARBOSA, Denis. Proteção das marcas... Op. cit. p. 46: O autor utiliza o exemplo citado por BEEBE, das propagandas da marca BENETTON, as quais utilizavam imagens de guerra, doenças, sacrilégios e com a mera aposição da marca do anunciante. Tal prática não tinha o condão de desenvolver o significado da marca ou aumentar o valor da marca, mas somente o de oferecer ao público informação que diferenciasse a marca BENETTON dos demais concorrentes. E fez isso com sucesso. BARBOSA, Denis. Op. cit. p. 46. n. 19. apud BEEBE, Barton. The semiotic analysis of trademark Law. In UCLA Law Review v. 51. 2004. p. 644.
} 
ao ser mal manuseado pelo profissional da construção civil. Da mesma forma, a distintividade e a distinção de uma marca podem ser erodidos, comprometendo sua integridade material, caso a mesma não seja utilizada devidamente por seu titular ou por terceiros. ${ }^{11}$ Ou se utilizada para substituir o significado semântico do próprio produto ou serviço que a mesma designa, diminuirá seu poder distintivo, podendo tornar-se res communis omnium.

Adicionalmente, a integridade moral ou reputação de um titular de marca, novidade trazida pelo artigo 130, inciso III da LPI $^{12}$, pode ser atingida quando um concorrente a utiliza de modo a denegrir seu titular junto aos consumidores e mercado. Dessa forma, o titular da marca ${ }^{13}$ sofrerá danos não materiais que afetam sua credibilidade, fulminando seu poder de competição frente aos concorrentes, perdendo posição de mercado, abalando a sua integridade moral. ${ }^{14}$

Conseguindo resumir alguns dos objetivos do presente trabalho, pois há outros pontos aqui abordados que não estão presentes em seu estudo, o autor americano Frank I. SCHECHTER, em 1927, disse que "[a] preservação da unicidade de uma marca deve constituir a única base racional para a sua proteção". ${ }^{15}$

O que ele quis dizer, já naquela época, era que o aproveitamento de marcas com certa fama em seus mercados precisa ser coibido de modo a evitar que a sua força distintiva não seja desgastada ou diluída, mantendo-se sua integridade material a mais intacta possível. Não à toa que os Estados Unidos tenham sido o país com a maior preocupação com casos envolvendo uso indevido de marcas famosas tanto por

${ }^{11}$ É o caso da caducidade de marcas, remédio para um sistema doente, objeto dos artigos 143 e seguintes da LPI.

${ }^{12}$ Art. 130, III LPI: Ao titular da marca ou ao depositante é ainda assegurado o direito de: III - zelar pela sua integridade material ou reputação.

${ }^{13}$ Súmula no 227 STJ: “A pessoa jurídica pode sofrer dano moral”: Em que pese o comentário sobre a possibilidade do titular da marca sofrer dano moral, o STJ já decidiu que atos desleais podem causar danos às empresas no que tange à sua reputação junto aos consumidores, concorrentes e por que não, perante a sociedade.

${ }^{14}$ A partir daqui, tentar-se-á chamar a reputação relacionada às marcas, de integridade moral, mas não se almeja com o presente estudo afirmar que a marca pode sofrer dano moral ou ser abalada em sua reputação. O que se afirma é que, a marca, enquanto bem intangível, possui características e história perante o mercado e seus consumidores. Independentemente do que pode se ouvir da jurisprudência, a marca não possui distintividade intrínseca, mas extrínseca.

${ }^{15}$ SCHECHTER, Frank I. The rational basis of trademark protection. In: Harvard Law Review, $n^{\circ} 40.1927$, p. 831. Tradução livre do original: "The preservation of the uniqueness of a trademark should constitute the only rational basis for its protection". 
competidores como por não concorrentes, e por consequência, a teoria anti-diluição tenha angariado tanta força naquele país.

\section{Justificativa da escolha do tema}

A integridade material de uma marca e a integridade moral de seu titular consistem em tutelas jurídicas relevantes ao estudo do uso. O artigo 130, inciso III da LPI é arcabouço jurídico recente no ordenamento nacional, em que pese a longa história da teoria da diluição americana que, de certa forma, inspirou o legislador pátrio a incluir timidamente tal instituto no Brasil.

Referido dispositivo vem sendo pouco estudado pela doutrina e quase nada interpretado pelos tribunais nacionais, o que também contribuiu para a escolha do tema. Ademais, a integridade da marca, enquanto tutela potencial de exclusão de terceiros, é pouco aproveitada pelos titulares por ausência de um estudo mais aprofundado.

A ausência na doutrina de estudo preocupado em examinar a unicidade das marcas e suas variações instigou a condução do presente trabalho, que tentará oferecer fundamentos mais claros sobre esse importante instituto jurídico, principalmente em tempos de multiplicação de sinais que ocupam o domínio comum, por um número cada vez maior de agentes econômicos motivados a proteger suas marcas.

\section{Principais questões a serem abordadas}

O presente estudo tentará demonstrar que o uso da marca por seu titular, por seus concorrentes e/ou pela sociedade é capaz de gerar efeitos à sua integridade material e moral. Para se obter essa conclusão, será necessário estudar o fenômeno jurídico da marca, sua atual definição doutrinária e legislativa, sua natureza jurídica, o feixe de direitos que nasce com o uso e com o registro da marca, além dos fenômenos jurídico-linguísticos originados como efeitos positivos e negativos causados pelo uso da marca no mercado. 


\section{Capítulo I \\ NOTAS SOBRE DIREITOS REAIS E MARCA}

É importante contextualizar os direitos reais para o presente estudo, tendo em vista que, apesar de distantes, o Direito Civil e os direitos sobre as marcas possuem paralelos interessantes que suscitam questionamentos jurídicos ainda sem pacificação. Um exemplo clássico refere-se à possibilidade de aquisição de propriedade intelectual através do usucapião. Não há pretensão de esgotar os institutos, mas sem dúvida, algumas linhas são interessantes para dirimir dúvidas sobre o direito de uso de marca e suas consequências.

Muitos criticam a ideia de fundamentar os direitos de propriedade sobre bens intelectuais ${ }^{16}$ paralelamente aos direitos de propriedade sobre bens materiais. Mas, como deixar de lado conceitos tão arraigados na doutrina comercial e civil capazes de ajudar a entender o que são, de fato e de direito, esses bens para a Economia do século XXI? Como não analisar institutos como a posse, a propriedade, o uso na concorrência, se são eles os exercidos quando da ocupação dos bens intelectuais? ${ }^{17}$

\section{Considerações introdutórias sobre posse}

De acordo com Clóvis BEVILÁQUA, o direito subjetivamente considerado é um poder de ação assegurado pela ordem jurídica. Anatomicamente ele compreende um sujeito, um objeto e a relação que os liga. Propriamente nesta relação é que está o direito, mas ela pressupõe os dois termos que se vinculam por sua interposição. ${ }^{18}$

A esses três elementos essenciais, BEVILAQUA citando PICARD, acrescenta o da proteção-coação, que é a tutela jurídica imanente a todo o direito. Quer isso dizer que todo o direito é provido de uma ação, que é o seu tegumento protetor, a força que dele se desprende quando o violam ou ameaçam. ${ }^{19} \mathrm{E}$ continua o autor afirmando que o interesse

\footnotetext{
${ }^{16}$ BARBOSA, Cláudio. Op. cit. p. 12: "[b]em intelectual é a fixação de uma criação intelectual legalmente protegida em um meio tangivel".

${ }^{17}$ Preferível o uso do termo "intelectual" pois está relacionado ao que nasce do intelecto, e não, "imaterial" que tem relação com o que não possui corpo. Cf. BARBOSA, Cláudio. Op. cit. p. 15.

${ }^{18}$ BEVILÁQUA, Clóvis: Teoria Geral do Direito Civil: São Paulo: Servanda, 2007. p. 73.

${ }^{19}$ BEVILÁQUA, Op. cit. p. 74.
} 
não é puramente econômico, compreende também: a personalidade, a liberdade, a honra, os laços de família. ${ }^{20} \mathrm{Na}$ linguagem filosófica, é tudo quanto corresponde à solicitação dos desejos dos homens. Neste sentido é que ULPIANO dizia "[b]ona ex eo dicuntur quod beant, hoc est beatus faciut. Para a economia política, o bem é aquilo que concorre para satisfazer uma necessidade humana. ${ }^{21}$

É necessário distinguir bem de coisa pois nem tudo que se define como bem pode ser chamado de coisa. Por exemplo, a liberdade, a honra, a vida são bens, mas não são coisas. Coisa pode ser interpretada como tudo o que pode ser objeto de direitos reais. TEIXEIRA DE FREITAS define coisa como todo o objeto material suscetível de medida de valor. Como afirma BEVILÁQUA, coisas podem ser conceituadas também como tudo o que pode ser acrescido ao patrimônio como a posse, os direitos reais, os direitos intelectuais, os direitos obrigacionais, as relações econômicas do direito da família e as ações oriundas desses direitos, as quais, em verdade, não passam de aspectos dos mesmos. $^{22}$

Sílvio VENOSA anotou que “[S]em a credibilidade da sociedade nos estados de aparência, inviável seria a convivência. A cada instante, defrontamos com situações aparentes que tomamos como verdadeiras e corretas. (...) Se a sociedade não pode prescindir da aparência para sua sobrevivência, o direito não pode furtar-se de proteger estados de aparência, sob determinadas condições, porque se busca, em síntese, a adequação social". ${ }^{23}$

A ideia apresentada pelo autor sugere que, em que pese a relação de fato e de direito envolvidos na posse, seria extenuante para a sociedade ter que decidir sempre que o direito à coisa tiver que ser manifestado. Se a cada uso de bem móvel ou imóvel, corpóreo ou incorpóreo, houvesse necessidade de se provar que o utente é, de fato e de direito, o possuidor da coisa, haveria o esgotamento do sistema sem evolução das relações. Por isso,

\footnotetext{
${ }^{20}$ BEVILÁQUA, Op. cit. p. 75.

${ }^{21}$ BEVILÁQUA, Op. cit. p.. 225. Ideia livre traduzida para o Português: "a aquisição de bens faz o homem feliz".

${ }^{22}$ BEVILÁQUA. Op. cit. p. 231/232.

${ }^{23}$ VENOSA, Sílvio de Salvo. Direito Civil. Direitos Reais. $3^{\text {a }}$ ed. São Paulo: Atlas, 2003. p. 41.
} 
o estado da aparência, aos olhos de VENOSA, é tão importante. Na visão dele, " $a$ prestação jurisdicional tardaria e instaurar-se-ia inquietação social". ${ }^{24}$

Analisando a posse com comprometimento, Savigny ${ }^{25}$ e Ihering $^{26}$ contribuíram para o aperfeiçoamento da análise dos direitos das coisas, cujos berços principais, o Direito Romano, Francês e Alemão, promoveram debates sobre seu modo e limites.

Comentando sobre Savigny e Ihering, Limongi FRANÇA anota a diferença das duas teorias defendidas pelos autores. "[P] ara o primeiro, tem-se a posse de uma coisa, quando se tem a possibilidade não somente de dispor dela fisicamente, mas ainda de a defender contra toda ação estranha. Já no entender do segundo, a posse é a exteriorização da propriedade, entendendo-se por tal o estado normal externo da coisa sobre o qual ela atinge sua destinação econômica de servir aos homens." ${ }^{27}$

VENOSA escreveu que "[P]ara o leigo que se debruça desprevenidamente sobre o problema [teorias de Savigny e Ihering], possuir é ter uma coisa em seu poder, podendo dela usar e gozar. É a compreensão daquilo que a mão toca e mantém fisicamente junto ao corpo. Essa é a noção primitiva. No entanto, quando a civilização torna-se mais complexa, surge a compreensão de posse que não requer o permanente contato físico com o objeto. Posso ser possuidor de bens sem estar presente no local. A possibilidade física não exige a detenção". ${ }^{28}$

$\mathrm{Na}$ visão de Ihering, segundo VENOSA, "[O] importante é fixar o destino econômico da coisa. O possuidor comporta-se como faria o proprietário. O animus está

\footnotetext{
${ }^{24}$ VENOSA, Sílvio de Salvo. Op. cit. p. 42.

${ }^{25}$ Friedrich Carl von Savigny publicou em 1803 seu Tratado da Posse (Das Recht des Besitzes), explicando tal instituto à base de dois elementos: o corpus (elemento material que se traduz no poder físico da pessoa sobre a coisa) e o animus (o elemento intelectual que representa a vontade de ter a coisa como própria). De acordo com o autor, um não podia existir sem o outro.

${ }^{26}$ Ihering, opositor de Savigny, é responsável pela Teoria Objetiva dos Direitos Reais, ou seja, posse e propriedade precisam ser definidas como direitos emanados do poder sobre a coisa. Diferente de Savigny, para Ihering, não importa se inexiste o animus, simplesmente existe o direito sobre a coisa. Se esse direito é esbulhado, trata-se de clássica relação entre o proprietário que não possui a coisa e possuidor que possui injustamente a coisa. Para Ihering, posse é fato e propriedade é direito. Desta feita, parece que Ihering é quem mais influenciou nosso Direito, posto que a posse é um dos feixes emanados da propriedade, tal como nosso antigo ordenamento civil dispunha (art. 485 e seguintes da Lei $n^{\circ}$ 3.071/1916) e o atual dispõe (Art. 1228 e seguintes da Lei $\mathrm{n}^{\circ}$ 10.406/2002).

${ }^{27}$ FRANÇA, R. Limongi. Instituições de Direito Civil. 5a ed. rev. e atual. São Paulo: Saraiva, 1999. p. 381.

${ }^{28}$ VENOSA, Sílvio de Salvo. Op. cit. p. 50.
} 
integrado no conceito de corpus". E finaliza afirmando que "[A] superioridade da teoria de Ihering repousa exatamente na maior facilidade de distinguir-se a posse da detenção. Em princípio, toda situação material envolvendo o titular à coisa é posse, salvo se o ordenamento a exclui, quando então se considerará a situação como de mera detenção", ${ }^{29}$

As espécies de posse são: 1) posse direta e indireta; 2) posse justa e injusta; 3) posse de boa-fé e de má-fé; 4) posse ad usucapionem e ad interdicta; 5) posse nova e velha; 6) jus possiendi e jus possessionis; 7) posse natural e civil; 8) posse, quase-posse e composse; 9) posse pro diviso e pro indiviso.

Para o presente estudo, listar todos os tipos de posse faz sentido, bem como entender o que significar a posse de boa-fé, ad usucapionem, jus possessionis, posse civil e composse. De acordo com Limongi FRANÇA, posse de boa-fé "é aquela em que o possuidor ignora o vício ou obstáculo que lhe impede a aquisição da coisa”. Posse ad usucapionem é a posse capaz de gerar propriedade, na qual "um sujeito se assenhoreia de uma res nullius, detendo-a mansa e pacificamente durante certo tempo". ${ }^{30}$ Jus possessionis é a posse fundada no fato da posse, ou seja, aquela que se procede sem justo título de propriedade sobre a coisa. Posse civil é aquela fundada na lei. "Composse é a posse comum de duas ou mais pessoas sobre o mesmo objeto. (...) a posse de cada um é apenas de uma parte ideal". 31

A questão da posse de direitos é enfrentada por VENOSA, ao explicar que o Direito Romano só aceitava a possibilidade de posse de coisas corpóreas. Na Idade Média, aceitou-se a hipótese de se proteger a posse de direitos pessoais referentes a cargos públicos ou eclesiásticos. No Brasil, o assunto também foi enfrentado por Ruy Barbosa na defesa da manutenção dos cargos de professores da Escola Politécnica do Rio de Janeiro, em $1896 .{ }^{32}$

Mais recentemente, a ideia de posse de direitos foi objeto de discussão quanto à proteção ao direito de uso de linhas telefônicas, quando as mesmas possuíam certo valor

\footnotetext{
${ }^{29}$ VENOSA, Sílvio de Salvo. Op. cit. p. 56.

${ }^{30}$ FRANÇA, R. Limongi. Op. cit. p. 383.

${ }^{31}$ FRANÇA, R. Limongi. Op. cit. p. 384.

${ }^{32}$ VENOSA, Sílvio de Salvo. Op. cit. pp. 56/57.
} 
econômico. "[N] a linha telefônica, ou outras linhas assemelhadas para transmissão de dados, reconhece-se um direito real de uso de coisa móvel; portanto, passivel de posse”." Essa orientação culminou com a edição da Súmula 193 pelo STJ: "O direito de uso de linha telefônica pode ser adquirido por usucapião”.

Seguindo essa linha, Sílvio VENOSA não descarta, por consequência, a possibilidade de posse de direitos intelectuais, posto que direitos pessoais recaem sobre coisas incorpóreas, como as linhas telefônicas. Nesse sentido, o autor cita o REsp $\mathrm{n}^{\circ}$ 7.196/RJ, no qual ficou decidido que:

CIVIL - INTERDITO PROIBITÓRIO - PATENTE DE INVENÇÃO DEVIDAMENTE REGISTRADA - DIREITO DE PROPRIEDADE. I - A DOUTRINA E A JURISPRUDENCIA ASSENTARAM ENTENDIMENTO SEGUNDO O QUAL A PROTEÇÃO DO DIREITO DE PROPRIEDADES, DECORRENTE DE PATENTE INDUSTRIAL, PORTANTO, BEM IMATERIAL, NO NOSSO DIREITO, PODE SER EXERCIDA ATRAVES DAS AÇÕES POSSESSÓRIAS.

II - O PREJUDICADO, EM CASOS TAIS, DISPÕE DE OUTRAS AÇÕES PARA COIBIR E RESSARCIR-SE DOS PREJUIZOS RESULTANTES DE CONTRAFAÇÃO DE PATENTE DE INVENÇÃO. MAS TENDO O INTERDITO PROIBITORIO INDOLE, EMINENTEMENTE, PREVENTIVA, INEQUIVOCAMENTE, E ELE MEIO PROCESSUAL MAIS EFICAZ PARA FAZER CESSAR, DE PRONTO, A VIOLAÇÃO DAQUELE DIREITO. III - RECURSO NÃO CONHECIDO ${ }^{34}$

Para VENOSA, portanto, “[S]endo passível de posse tudo o que for possível de utilização, o exercício desse poder de utilização deve ser inserido na compreensão do termo legal. Cuida-se do exercício dos direitos reais, enfim. Aplica-se tanto aos direitos corpóreos, como incorpóreos". 35

O assunto também já foi abordado por Pontes de MIRANDA, quando o autor escreveu que " $[A]$ pretensão ao interdito proibitório pode existir, seja ou não corpóreo o bem. $O$ interdito de que se fala é possessório; e objeto da posse tanto pode ser bem corpóreo quanto incorpóreo (obra intelectual, invenção, desenho de utilidade ou modelo industrial, marca de indústria e comércio, sinal de propaganda, indicação de

\footnotetext{
${ }^{33}$ VENOSA, Sílvio de Salvo. Op. cit. p. 59. Julgados nesse sentido: REsp n 41.611-6, RT 623/187, RT 476/89, 500/109 e 591/137

${ }^{34}$ VENOSA, Sílvio de Salvo. Op. cit. p. 60. REsp n 7.196/RJ. Terceira Turma. Rel. Min. Waldemar Zveiter. Julgado em 10/06/1991. Publicado no DJu de 05/08/1991.

${ }^{35}$ VENOSA, Sílvio de Salvo. Op. cit. p. 99.
} 
proveniência). Onde quer que possa ser objeto de propriedade o bem, pode haver posse. Se pode haver posse, pode haver tutela jurídica possessória”, ${ }^{36}$

Denis BARBOSA traz outro julgado sobre a possibilidade de se intentar ações de interdito proibitório em casos de uso indevido de Direitos Autorais:

"Ementa - (...) Em matéria de direitos autorais, por terem estes conteúdo dominial, a posse direta não se faz imprescindível que esteja sendo exercida pelo autor para que o possibilite ao exercício da ação de interdito proibitório, haja vista que esta ação visa impedir o uso não autorizado da propriedade intelectual". 37

Limonge FRANÇA organiza as formas de perda da posse de acordo com a participação da vontade do sujeito, de acordo com o objeto e com o sujeito. Com a participação do sujeito, a posse pode ser perdida de forma voluntária (abandonando-se a coisa, entregando-a a outrem e por constituto possessório) ou involuntária (por destruição da coisa, perda da coisa, por decisão judicial, por posse de outrem ou pela colocação da coisa fora do comércio). ${ }^{38}$

\section{Considerações introdutórias sobre propriedade}

VENOSA anota que a propriedade não existia nas sociedades primitivas e por isso, as coisas não tinham donos. "Delas apropriava-se o primeiro ocupante. O Direito Romano cristalizou a ideia de que a res nullius pertence naturalmente ao primeiro tomador. A coisa é sem dono porque nunca o teve ou porque houve abandono por parte do titular (res derelicta). Efetiva-se a propriedade pela apreensão da coisa, com a intenção do agente de tê-la como própria". 39

\footnotetext{
${ }^{36}$ MIRANDA, Pontes de: Comentários ao Código de Processo Civil, t. XIII/309-310. Apud BARBOSA, Denis Borges. Doutrina da Concorrência PI(2). Apresentação de slides disponível em http://www.denisbarbosa.addr.com\%2Farquivos\%2Fapostilas\%2Fpuc\%2FDoutrina\%2520da\%2520Concorre ncia.ppt\&ei=HD2IUN7NH4To9AS25ICoAQ\&usg=AFQjCNHwPjChTB7GIJRm-1FNUHEVwvu9kg. Slide $n^{\circ} 10$. Acessado em 15 de novembro de 2012.

${ }^{37}$ BARBOSA, Denis Borges. Doutrina... Op. Cit. Slide 07. Acessado em 15 de novembro de 2012. Agravo de instrumento n 0057541900 Comarca de Origem: Curitiba. Quinta Câmara Cível. Rel. Juiz Cícero da Silva. Decisão unânime. Data de publicação: 25.02.94.

${ }^{38}$ FRANÇA, R. Limongi. Op. cit. p. 395.

${ }^{39}$ VENOSA, Sílvio de Salvo. Op. cit. p. 214.
} 
VENOSA ainda anota que " $[A]$ propriedade, ao contrário da posse, não tem a mesma facilidade intuitiva de percepção. Assinalamos que a posse, sendo preexistente ao direito, como fato natural, converte-se em fato jurídico, e assim é protegida. O ser humano primitivo tem perfeita noção da apreensão material da coisa e a vontade de tê-la para $s i, \cdot 40$

No modo de ver de KOHLER, a propriedade é um direito, mas não se deve chamar relação de direito, porque os multíplices efeitos, que ela produz, não são mais atingidos pela ordem jurídica. ${ }^{41}$

De acordo com BEVILÁQUA, a propriedade é uma relação de direito; as regras de direito referentes à propriedade articulam-se entre si, formam um todo, que é o instituto da propriedade. ${ }^{42}$

A propriedade é o direito mais amplo e absoluto sobre as coisas. Ele constitui o ius utendi, fruendi et abutendi. O direito de usar é o de beneficiar-se com as utilidades da coisa. O de fruir é o direito de usufruir dos frutos advindos da coisa e o de dispor confere ao proprietário o direito de abandonar a coisa, aliená-la e de autolimitá-la. O direito de propriedade é perpétuo combinando com a faculdade de dispor da coisa.

Uma espécie de propriedade que merece comentário é a propriedade resolúvel, que se alinha com a característica finita da validade das marcas. Na visão de Limongi FRANÇA, “[P]ropriedade resolúvel é o mesmo que propriedade revogável. É uma exceção à regra da perpetuidade da propriedade. (...) [p]ropriedade resolúvel ou revogável é aquela que termina, em virtude de condição ou termo estabelecido por declaração de vontade ou disposição de lei, na própria causa jurídica, ou em razão de fato posterior, hábil a gerar tal efeito". 43

Conforme ensinamento de Limongi FRANÇA, “[a] coisa não se perde jamais pelo simples não uso, a menos que haja a configuração do abandono, o qual exige dois

\footnotetext{
${ }^{40}$ VENOSA, Sílvio de Salvo. Op. cit. p. 151.

${ }^{41}$ KOHLER, Joseph: Lehrbuch, §47. Apud BEVILÁQUA, Op. cit. p. 77.

${ }^{42}$ BEVILÁQUA. Op. cit. p. 90.

${ }^{43}$ FRANÇA, R. Limongi. Op. cit. p. 444.
} 
elementos, a saber, o objetivo (derrelição) e o subjetivo (a intenção de abandoná-la) ". ${ }^{44} \mathrm{O}$ autor continua afirmando que a propriedade, quando exercida em sua plenitude, não admite concorrência de uso, posto que confere exclusividade ao sujeito de direito. ${ }^{45}$ A exceção é o condomínio que oferece a possibilidade de co-propriedade e composse pro indiviso, características que se colocam em paralelo com a ubiqüidade do uso de marca.

\section{Considerações introdutórias sobre usucapião}

A posse prolongada da coisa pode conduzir à aquisição da propriedade, se presentes determinados requisitos estabelecidos em lei. "[N]o direito de Justiniano, o usucapião resulta da fusão de dois institutos de mesma índole, mas com campos diversos de atuação, a usucapio e a longi temporis praescriptio". ${ }^{46}$

A possibilidade de a posse continuada gerar a propriedade justifica-se pelo "sentido social e axiológico das coisas". É premiado aquele que utiliza o bem com utilidade, em detrimento daquele que deixa de utilizar o bem e não questiona a utilização por aquele que não é dono. ${ }^{47}$

Usucapião, portanto, é um modo originário de adquirir a propriedade, fundado na posse continuada do objeto, de acordo com os requisitos previstos em lei.

\section{Considerações introdutórias sobre o direito de uso}

O uso é o fato jurídico ${ }^{48}$ de ocupação de determinada coisa que provoca o nascimento de relações jurídicas entre o utente, a coisa e terceiros. De acordo com a doutrina mais recente, o uso é uma das formas de expressão dos direitos de posse e de propriedade que tornam visíveis os feixes de direitos oriundos dessas externalidades frente

\footnotetext{
${ }^{44}$ FRANÇA, R. Limongi. Op. cit. p. 405.

${ }^{45}$ FRANÇA, R. Limongi. Op. cit. p. 406.

${ }^{46}$ VENOSA, Sílvio de Salvo. Op. cit. p. 191.

${ }^{47}$ VENOSA, Sílvio de Salvo. Op. cit. p. 192. Continua o autor dizendo que "[O] usucapião deve ser considerado modalidade originária de aquisição, porque o usucapiente constitui direito à parte, independentemente de qualquer relação jurídica com anterior proprietário”.

${ }^{48}$ Marcos Bernardes de Melo, citando Passarelli, afirma que fatos jurídicos são os que produzem um evento jurídico que pode consistir na modificação ou extinção de uma relação jurídica ou na substituição de uma relação por uma nova. MELO, Marcos Bernardes de. Teoria do Fato Jurídico. Plano da Existência. $16^{\mathrm{a}}$ Edição. São Paulo: Saraiva, 2010. p. 112.
} 
à sociedade. E como tal, exerce verdadeiro fascínio àqueles que se debruçam a estudar seu conceito, modos e efeitos.

Conceituando uso, Limongi FRANÇA diz que "uso é o desmembramento da propriedade que atribui ao usuário o direito de fruir as utilidades da coisa, dentro dos limites das necessidades pessoais suas e de sua família". ${ }^{49}$

Já na visão de VENOSA, “[O] usus, em seu significado originário, era o direito de usar uma coisa sem receber os frutos. Era dirigido a coisas que não o produziam, não se levando em conta a possibilidade de auferir qualquer fruto civil. (...) $O$ uso representa o ius utendi por inteiro, consagrando o direito de retirar da coisa tudo que for assim suscetível, sem receber nenhum fruto. $O$ usuário poderia servir-se da coisa, porém não poderia ceder seu exercício, porque o preço do aluguel seria fruto civil". 50

\subsection{O uso como fator de concorrência}

A Constituição Federal $^{51}$ assegura o livre exercício de qualquer atividade econômica, independentemente de autorização do Poder Público, salvo nos casos previstos em lei. O exercício do princípio constitucional da livre concorrência é uma manifestação da liberdade de iniciativa econômica privada.

Na Economia, a concorrência corresponde à situação de um mercado em que os diferentes produtores/vendedores de um determinado bem ou serviço atuam simultaneamente e de forma independente numa mesma localidade, face aos compradores/consumidores, com vistas a alcançar um objetivo para o seu negócio - lucros, vendas e/ou quota de mercado - utilizando diferentes instrumentos, tais como os preços, a qualidade dos produtos, os serviços pós venda.

\footnotetext{
${ }^{49}$ FRANÇA, R. Limongi. Op. cit. p. 499.

${ }^{50}$ VENOSA, Sílvio de Salvo. Op. cit. p. 449.

${ }^{51}$ Art. 10 CF/88: “A República Federativa do Brasil, formada pela união indissolúvel dos Estados e Municípios e do Distrito Federal, constitui-se em Estado Democrático de Direito e tem como fundamentos: (...) IV - os valores sociais do trabalho e da livre iniciativa; (...)" - Art. 170 CF/88. "A ordem econômica, fundada na valorização do trabalho humano e na livre iniciativa, tem por fim assegurar a todos existência digna, conforme os ditames da justiça social, observados os seguintes princípios: (...) IV - livre concorrência; (...) Parágrafo único. É assegurado a todos o livre exercício de qualquer atividade econômica, independentemente de autorização de órgãos públicos, salvo nos casos previstos em lei”.
} 
A concorrência é própria do regime de economia de mercado. A disputa entre empresas é conseqüência natural. A concorrência constitui o motor do sistema econômico e é o elemento dinamizador do mercado que atinge o seu objetivo social, levando bens e serviços, oriundos dos agentes econômicos mais preparados, à população. É a concorrência que permite a pesquisa e o desenvolvimento de novas tecnologias, proporcionando a corrida entre os agentes econômicos, que além de investirem em seus produtos e serviços, também precisam competir em preços e fomentar o desejo de consumo na sociedade.

É um estado dinâmico de um mercado que estimula as empresas a investir e a inovar com vista à maximização dos seus ganhos e ao aproveitamento ótimo dos recursos escassos disponíveis. Um mercado concorrencial é aquele cujo funcionamento é feito de acordo com o livre jogo da oferta e da procura, sem intervenção do Estado.

Se o direito de uso exercido dentro da concorrência for "compativel $e$ razoável” com o direito de concorrência lícita, não haverá intervenção do Estado de forma a repreender a prática, mantendo-se o princípio da livre iniciativa e da livre concorrência. Outrossim, a livre iniciativa e concorrência oportunizam o desvio de clientela lícito, cujos meios utilizados pelos concorrentes devem obedecer os limites impostos pela lei e pelas regras de mercado.

Essa limitação é exatamente uma exceção às regras do jogo de mercado.

No campo da Propriedade Intelectual, mais especificamente o de marcas, o direito de uso confere limite à livre iniciativa, tendo em vista que, ao adquirir a propriedade sobre a marca, adquire-se por consequência, o seu direito de uso exclusivo em todo território nacional. ${ }^{52}$ Mesmo levando-se em consideração o limite do princípio da especialidade ${ }^{53}$, a marca, como qualquer bem intelectual, configura uma proibição ao

\footnotetext{
${ }^{52}$ Art. 129 LPI. "A propriedade da marca adquire-se pelo registro validamente expedido, conforme as disposições desta Lei, sendo assegurado ao titular seu uso exclusivo em todo o território nacional, observado quanto às marcas coletivas e de certificação o disposto nos arts. 147 e 148 ".

${ }^{53}$ Art. 124 LPI. "Não são registráveis como marca: $\boldsymbol{X I X}$ - reprodução ou imitação, no todo ou em parte, ainda que com acréscimo, de marca alheia registrada, para distinguir ou certificar produto ou serviço idêntico, semelhante ou afim, suscetível de causar confusão ou associação com marca alheia;",
} 
direito de concorrer pois elimina a possibilidade do concorrente em utilizar a marca do outro, salvo alguns limites. ${ }^{54}$

Denis Borges BARBOSA anota que uma marca tem efeito na concorrência, especialmente como meio de viabilizar o investimento em criação de imagem relativa ao produto ou serviço. Continua o autor afirmando que as pessoas falam marcas, usam delas para distinguir bens e serviços, e as empresas usam-nas para afirmar e ampliar imagem. ${ }^{55}$

Em sentido menos econômico e mais consumerista, Tullio ASCARELLI anota que “[p] roteção da marca não é nem um prêmio o esforço de criação intelectual, que pode ser protegido em si mesmo, ou uma recompensa para os investimentos em publicidade, é uma ferramenta de diferenciação para a concorrência (...)". ${ }^{56}$

Denis BARBOSA ainda faz uma análise sistêmica sobre a concorrência e a Propriedade Intelectual, ao afirmar que " $[o]$ direito de competir a que se refere o art. $1^{o}$ da nossa Carta é o direito de livre cópia das criações técnicas e estéticas. A chave da propriedade intelectual é que está fora dos limites muito estritos da proteção concedida, o público tem direito livre de copiar". 57 E continua o autor ensinando que "[N] um sistema jurídico em que haja liberdade de iniciativa, ou seja, acesso juridicamente livre à atividade econômica, e livre concorrência, ou seja, autolimitação do Estado em face da prática privada desta mesma atividade, surge um espaço de proliferação de interesses econômicos sem condicionamento primário de Direito". 58

\footnotetext{
${ }^{54}$ Art. 132 LPI. “O titular da marca não poderá: I - impedir que comerciantes ou distribuidores utilizem sinais distintivos que lhes são próprios, juntamente com a marca do produto, na sua promoção $e$ comercialização; II - impedir que fabricantes de acessórios utilizem a marca para indicar a destinação do produto, desde que obedecidas as práticas leais de concorrência; III - impedir a livre circulação de produto colocado no mercado interno, por si ou por outrem com seu consentimento, ressalvado o disposto nos $\$ \$ 3^{\circ}$ e $4^{\circ}$ do art. 68; e IV - impedir a citação da marca em discurso, obra científica ou literária ou qualquer outra publicação, desde que sem conotação comercial e sem prejuizo para seu caráter distintivo”.

${ }^{55}$ BARBOSA, Denis. Proteção das marcas... Op. cit. p. 129. No mesmo sentido, BITTAR, Carlos Alberto e BITTAR FILHO, Carlos Alberto. Tutela dos direitos da personalidade e dos Direitos Autorais nas Atividades Empresariais. São Paulo: RT, 1993. p. 97.

${ }^{56}$ ASCARELLI, Tullio. Teoria della concorrenza e dei beni imateriali. Milão: Giuffrè, 1956. p. 482. Tradução livre de: “[p]rotezione del marchio non è né un premio ad un sforzò di creazione intellettuale, che può essere protetto da se stesso, o un premio per gli investimenti in pubblicità, è uno strumento di differenziazione par competizione (...)".

${ }^{57}$ BARBOSA, Denis Borges. Doutrina... Op. Cit. Slide 22. Acessado em 15 de novembro de 2012.

${ }^{58}$ BARBOSA, Denis Borges. Doutrina... Op. Cit. Slide 27. Acessado em 15 de novembro de 2012.
} 
A função social é alcançada com a manutenção de um fluxo de criação e circulação de informação, criando-se um valor econômico e social. Quando a proteção é excessiva, perde-se a função de incentivo, estanca-se a criação e a circulação da informação, e consequentemente, constata-se que a proteção gera externalidades negativas, acarretando um custo social. ${ }^{59}$

Assim, o direito de uso exercido na concorrência sofre repressão quando houver ilicitude na atividade econômica. No caso das marcas, o direito à tutela não é da marca em si, mas da sua integridade material e a integridade moral do agente econômico, reprimindo o desvio de clientela ilícito por confusão ou associação e o denegrimento do titular da marca ilicitamente reproduzida ou copiada.

\section{Natureza jurídica da marca}

Há intenso debate doutrinário e jurisprudencial a respeito da natureza jurídica dos bens intelectuais. Historicamente, o termo "propriedade" tem sido utilizado pela maioria das legislações nacional e estrangeira. Entretanto, críticas a essa denominação também têm sido desferidas, principalmente quando a comparação com a propriedade material comum encontra distinções jurídicas.

Na visão de Cláudio BARBOSA, a origem e a aceitação da nomenclatura "propriedade intelectual", como geralmente ocorre nas discussões jurídicas, não foi simples. De acordo com o autor, Clovis Beviláqua há muito mencionava no século XIX o termo direitos intellectuaes, um nome semelhante ao atual, todavia, mesmo nos dias de hoje, a matéria ainda não está totalmente pacífica. ${ }^{60}$

O mencionado autor também comenta com eloquência e acuidade que a utilização do termo "intelectual" é preferível ao termo "imaterial” porque em sua acepção comum, o "imaterial" não está necessariamente vinculado a uma atividade criativa, sendo, muitas vezes, associado a tudo aquilo que não tem matéria. Por isso, convém-se privilegiar a interação com o intelecto, dando preferência ao termo "intelectual". ${ }^{6}$

\footnotetext{
${ }^{59}$ BARBOSA, Cláudio, Op. cit. p. 53.

${ }^{60}$ BARBOSA, Cláudio, Op. cit. p. 08.

${ }^{61}$ BARBOSA, Cláudio, Op. cit. p. 15.
} 
Como a relação jurídica é complexa, muito se discutiu sobre a diferenciação dos aspectos pessoais da propriedade intelectual, quando comparados a outros aspectos privados. Isso é observado, de acordo com Cláudio BARBOSA, na diferenciação dos direitos pessoais e patrimoniais privados regulares de um titular de direito da propriedade intelectual, distinção proposta por José de Oliveira ASCENSÃO: “[q]uanto aos direitos intelectuais, têm em vista comportamentos funcionalmente dirigidos a reservar ao sujeito formas de desfrute desse bem intelectual. Mais em geral, os direitos de exclusivo ou de monopólio tendem à reserva de um exclusivo de actuação do sujeito restringindo-se nessa medida a normal liberdade dos restantes sujeitos". ${ }^{6}$

A Propriedade Intelectual, como os demais direitos de clientela, só se exerce sobre um objeto intelectual específico, o bem econômico, que assume natureza potencial de uma propriedade, quando satisfaz o requisito essencial de escassez e disponibilidade. ${ }^{63}$

Não se pode perder de vista que a proteção jurídica da marca não recai somente a ela, mas à possibilidade de utilização da mesma em um determinado segmento de mercado limitado aos produtos e serviços designados pela mesma. Nesse sentido, PÉROTMOREL afirma que " $[o]$ direito é aqui essencialmente relativo, neste senso de que não recai sobre o signo em si mesmo mas somente sobre a possibilidade de sua utilização dentro de um certo domínio". ${ }^{64}$ Com o mesmo entendimento, mas expressado de forma distinta, Paul MATHÉLY comenta que "não se pode confundir o objeto do direito e o alcance da proteção conferida ao direito sobre a marca", ${ }^{65}$

Na mesma linha, SCHECHTER, cita o caso Dunnachie \& Co. v. Young \& Sons, 4 Ct. Sess. Cas. (4th series) 874, 885 (1883), para dizer que “[m]onopólio não é o bem pelo que os autores contendem, e que os réus resistem. Ao contrário, concorrer

\footnotetext{
${ }^{62}$ ASCENSÃO, José de Oliveira. Direitos reais. $2^{\mathrm{a}}$ ed. Lisboa: Faculdade de Direito da Universidade de Lisboa, 1973. pp. 77/78.

${ }^{63}$ BARBOSA, Denis. Proteção das marcas... Op. cit. pp. 208/209.

${ }^{64}$ PÉROT-MOREL, Marie-Angèle. L'opposabilité dês antériorités em matière de marque de fabrique, de commerce ou de service. In Revue Trimestrielle de Droit Commercial, ano 24, v. 2, abr/jun 1971, p. 248. ${ }^{65}$ MATHÉLY, Paul: Le Noveau Droit Français des Marques. Vélizy Cedex: J.N.A., 1994:- Tradução livre do original: "Il ne faut pas confondre l'objet du droit, et l'étendue de la protection confere au droit sur la marque [...] La marque est protégée contre une usurpation, non seulment pour dês objets identifiques à ceux designes dans le depôt, mais encore pour des objets similaires".
} 
lealmente é toda proteção na qual a lei é invocada" ${ }^{66}$ Com essa passagem, pode-se notar que SCHECHTER também entende que a proteção não recai sobre o bem em si, mas sobre o direito de uso do bem sobre um produto ou serviço.

\subsection{O direito de propriedade sobre a marca}

A expressão Propriedade Intelectual surgiu no século XVIII com o objetivo de fortalecer o direito do indivíduo sobre um bem intelectual, direito esse tido anteriormente como privilégios dos soberanos. O mundo ainda não estava acostumado a experimentar os direitos sobre bens intelectuais e por isso, era necessário que houvesse um direito muito bem demarcado e forte, de modo que os monarcas da época não tivessem chance de reaver tais direitos, diminuindo os riscos de perda dessa conquista dos indivíduos.

Sobre esse assunto, GAMA CERQUEIRA ${ }^{67}$ escreveu que somente depois de abolidos esses privilégios, quando na França se promulgou a primeira lei sobre patentes de invenção (1793), cogitou-se saber qual é a natureza dos direitos de autor e de inventor, que as leis passaram a reconhecer, outorgando-lhes os respectivos estatutos jurídicos. E os primeiros jurisconsultos que se ocuparam desses estudos qualificaram-nos como direito de propriedade, ou entre os direitos de propriedade.

O uso da expressão propriedade foi considerado estratégico por esses motivos e historicamente, a mesma foi utilizada em quase todos os documentos internacionais ${ }^{68}$ sobre a matéria. A terminologia foi caracterizada pelo aspecto pragmático de sua definição, funções e efeitos, a fim de situar os bens intelectuais protegidos no rol das propriedades, alcançando alto grau de proteção enquanto bem jurídico tutelado legalmente.

Propriedade, na visão de Rachel SZTAJN, é relação jurídica entre pessoas, sujeitos de direito e bens que se caracteriza como poder para excluir da apropriação ou

\footnotetext{
${ }^{66}$ SCHECHTER. Op. cit. p. 833. Tradução livre do original: "[m]onopoly is not the thing for which the complainers contend, and which the respondents resist. On the contrary, fair trading is all for the protection of which the law is invoked".

${ }^{67}$ GAMA CERQUEIRA, Op. cit. Vol. I, p. 54.

${ }^{68}$ Convenção da União de Paris, Convenção da OMPI, Tratado de Madri, Protocolo de Madri, TRIPs, entre outros.
} 
apreensão por quaisquer terceiros. A tutela jurídica garante o proprietário contra a expropriação injustificada de seus bens. ${ }^{69}$

Newton SILVEIRA ${ }^{70}$ anotou que o direito real mais característico é o da propriedade, que pode ser definido como o direito mais amplo que um sujeito de direito tem sobre um bem externo a ele. O Direito romano o definia como ius utendi, fruendi et abutendi, que pode ser traduzido como o direito de usar a coisa, obter rendimento dela e dela dispor.

Revendo o ordenamento nacional, GAMA CERQUEIRA ${ }^{71}$ foi aquele que mais dispôs das noções legislativas nacionais, denotando que a nomenclatura propriedade vem sendo utilizada em quase todas as leis brasileiras, desde a primeira lei sobre marcas de $1875^{72}$, passando pela Constituição de $1891^{73}$, e à época de seu Tratado da Propriedade Industrial, o Código da Propriedade Industrial de $1945 .{ }^{74} \mathrm{O}$ uso do termo propriedade seguiria incólume após a exposição do comentado autor, pela Lei da Propriedade Industrial de $1971^{75}$, a Constituição Federal de $1988^{76}$ e finalmente, a atual Lei da Propriedade Intelectual de $1996 .^{77}$

${ }^{69}$ SZTAJN, Rachel. Teoria jurídica da empresa. Atividade empresária e mercados. São Paulo: Atlas,
2004. p. 30.
${ }^{70}$ SILVEIRA, Newton. Propriedade Intelectual. Propriedade Industrial. Direito de Autor. Software, Cultivares, Nome Empresarial. $4^{a}$ Edição revisada e ampliada. São Paulo: Manole, 2010. p. 83. No mesmo sentido, BARBOSA, Denis. Proteção das marcas... Op. cit. p. 264: “À luz dos artigos 129 e 130 da LPI, e fazendo incidir sobre tais dispositivos a iluminação do artigo 1196 do Código Civil, pareceria razoável distinguir posse quando o titular de marca tem de fato o exercício, pleno ou não, dos poderes ou de usus, fructus, abusus ou do jus persequendi, inerentes à propriedade - e de regra o titular da marca os têm todos". ${ }^{71}$ GAMA CERQUEIRA, Op. cit. vol. I, p. 49-53. No mesmo sentido, JHERING. Actio injuriaarum, p. 161. e PIPIA. Diritto industriale, p. 200. Apud BEVILÁQUA. Op. cit. 85.

${ }^{72}$ GAMA CERQUEIRA, Op. cit. vol. I, p. 50: “A primeira lei sobre marcas, de 1875, reconhecia aos negociantes e fabricantes o direito de marcarem seus produtos, declarando, entretanto, que ninguém poderia reivindicar a propriedade exclusiva da marca sem lhe ter feito previamente o registro".

${ }^{73}$ Art. 72 Constituição de 1891: “A Constituição assegura a brasileiros e a estrangeiros residentes no País a inviolabilidade dos direitos concernentes à liberdade, à segurança individual e à propriedade, nos termos seguintes: parag. 27: A lei assegurará também a propriedade das marcas de fábrica".

${ }^{74}$ Art. 143 Código da Propriedade Industrial de 1945: Cabe comentar que o Decreto foi consubstanciado à época de um governo transitório entre a democracia e a ditadura militar. Mesmo assim, resquício da histórica utilização do termo propriedade se encontra nesse artigo onde estabelece que a "propriedade da marca" poderia ser transferida a terceiros.

${ }^{75}$ Art. 59 CPI: "Será garantida no território Nacional a propriedade da marca e o seu uso exclusivo àquele que obtiver o registro de acôrdo com o presente Código, para distinguir seus produtos, mercadorias ou serviços, de outros idênticos ou semelhantes, na classe correspondente à sua atividade”.

${ }^{76}$ Art. $5^{\circ}$ CF/88. "Todos são iguais perante a lei, sem distinção de qualquer natureza, garantindo-se aos brasileiros e aos estrangeiros residentes no País a inviolabilidade do direito à vida, à liberdade, à igualdade, à segurança e à propriedade, nos termos seguintes: $\mathbf{X X I X ~ - ~ a ~ l e i ~ a s s e g u r a r a ́ ~ a o s ~ a u t o r e s ~ d e ~}$ inventos industriais privilégio temporário para sua utilização, bem como proteção às criações industriais, à 
Mas a tradição tem reservado a palavra propriedade ${ }^{78}$ ao controle sobre bens tangíveis por uma extensão relativamente moderna. A construção do instituto da propriedade em nosso ordenamento possui raízes civil-constitucionais ${ }^{79}$, transbordando as definições para outros campos do Direito como a Propriedade Intelectual. ${ }^{80}$

Inevitável, a esse ponto, traçar um plano civil-constitucional de modo a tentar interpretar se a terminologia propriedade pode ser aplicada às relações jurídicas envolvendo bens de Propriedade Intelectual. Principalmente, pelo que se vê das críticas à fria análise perpetuada pelos defensores dos direitos sui generis sobre bens intelectuais.

A Constituição Federal de 1988 garante que a lei outorgará o direito de propriedade $^{81}$, que precisará atender à sua função social ${ }^{82}$, e a propriedade das marcas ${ }^{83}$, tendo-se como base o interesse social e o desenvolvimento tecnológico e econômico do País. Como se vê, o Constituinte expressou sua preocupação com os efeitos do uso da propriedade, e condicionou sua exploração ao alcance de fins menos privatistas. Alguns economistas criticam a idéia da função social da propriedade, pois, em tese, ela já alcança esse fim por si só, ao estabelecer possibilidades contratuais, trabalhistas e tributárias.

propriedade das marcas, aos nomes de empresas e a outros signos distintivos, tendo em vista o interesse social e o desenvolvimento tecnológico e econômico do País";

${ }^{77}$ Art. 129 LPI. Vide nota 52.

${ }^{78}$ BARBOSA, Denis Borges: O conceito de Propriedade Industrial. Texto disponível no link http://www.uj.com.br/publicacoes/doutrinas/2827/O_CONCEITO_DE_PROPRIEDADE_INTELECTUAL. Acessado em 30/06/2011.

${ }^{79}$ TEPEDINO, Gustavo e SCHREIBER, Anderson apud BARBOSA, Denis Borges. Proteção as Marcas... Op. cit. p. 221.

${ }^{80}$ BARBOSA, Denis Borges: Nota sobre a categoria constitucional da "propriedade das marcas".

Disponível em http://denisbarbosa.addr.com/notamarca2.pdf. Acessado em 02 de abril de 2011. "No entanto, não está menos correta a apreensão de outro eminente jurista brasileiro: “...no proprio Art. 72, $\S . \S 26$ e 27, da Constituição Nacional, (...) temos expressamente contempladas outras excepções ao principio da liberdade industrial, que ambas as Constituições limitam, já garantindo as marcas de fabrica em propriedades dos fabricantes, já reservando aos escriptores e artistas "o direito exclusivo" á reproducção das suas obras. Por essas disposições os manufactores exercem sobre suas obras, tanto quanto os inventores sobre os seus inventos, direitos exclusivos, mantidos pela Constituição, isto é, monopolios constitucionaes. A noção de Ruy Barbosa não nega à marca a natureza de propriedade, mas apenas a sujeita a mais um feixe de tensões constitucionais, além da simples função social. O que Ruy aqui expressa é que essa posição exclusiva em relação a uma marca se constrói num contexto necessariamente concorrencial, que implica que essa exclusividade tenha natureza de um monopólio; além do dever de se usar essa propriedade de acordo com sua função social, essa função presume um uso concorrencial socialmente adequado".

${ }^{81}$ Art. $5^{\circ}$, XXII CF/88. "é garantido o direito de propriedade;"

${ }^{82}$ Art. 5', XXIII CF/88. "a propriedade atenderá a sua função social”,

${ }^{83}$ Art. $5^{\circ}$, XXIX CF/88. 
Denis BARBOSA é claro ao comentar que o preceito constitucional da propriedade sobre a marca se dirige ao legislador, determinando a este tanto o conteúdo da Propriedade Industrial (“a lei assegurará...”), quanto à finalidade do mecanismo jurídico a ser criado ("tendo em vista..."). A cláusula final da Constituição torna claro que os direitos relativos à Propriedade Industrial não derivam diretamente da Constituição, mas da lei ordinária. $^{84}$

A lei civil ${ }^{85}$ estabelece que o proprietário possui a faculdade de usar, gozar e dispor da coisa, e o direito de reavê-la do poder de quem quer que injustamente a possua ou detenha. Na mesma linha da Constituição Federal, o Código Civil também dispõe de cláusula finalística para a propriedade ao estabelecer que o direito de propriedade deve ser exercido em consonância com as suas finalidades econômicas e sociais.

Por sua vez, a LPI $^{86}$ em vigor deixa claro que a propriedade da marca se adquire pelo registro validamente expedido pelo órgão competente, que nesse caso, é o INPI, autarquia federal criada em $1970^{87}$, e que possui sede histórica na cidade do Rio de Janeiro, apesar da disposição legislativa que aponta para sua sede em Brasília-DF.

Note-se que o dispositivo especial da LPI não condiciona a exploração da marca espelhando-se no interesse social e no desenvolvimento tecnológico e econômico do país. No fundo, tal cláusula não se faz necessária nos limites da Propriedade Intelectual vez que, tal bem intelectual já é per se um impulsionador natural do desenvolvimento da humanidade.

\footnotetext{
${ }^{84}$ BARBOSA, Denis. Proteção das marcas... Op. cit. p. 220.

${ }^{85}$ Art. 1228 CC. "O proprietário tem a faculdade de usar, gozar e dispor da coisa, e o direito de reavê-la do poder de quem quer que injustamente a possua ou detenha. $\$ 1$ lo $O$ direito de propriedade deve ser exercido em consonância com as suas finalidades econômicas e sociais e de modo que sejam preservados, de conformidade com o estabelecido em lei especial, a flora, a fauna, as belezas naturais, o equilíbrio ecológico e o patrimônio histórico e artístico, bem como evitada a poluição do ar e das águas. $\$ 2 o$ São defesos os atos que não trazem ao proprietário qualquer comodidade, ou utilidade, e sejam animados pela intenção de prejudicar outrem. §3o O proprietário pode ser privado da coisa, nos casos de desapropriação, por necessidade ou utilidade pública ou interesse social, bem como no de requisição, em caso de perigo público iminente. $\S 40$ O proprietário também pode ser privado da coisa se o imóvel reivindicado consistir em extensa área, na posse ininterrupta e de boa-fé, por mais de cinco anos, de considerável número de pessoas, e estas nela houverem realizado, em conjunto ou separadamente, obras e serviços considerados pelo juiz de interesse social e econômico relevante. §5o No caso do parágrafo antecedente, o juiz fixará a justa indenização devida ao proprietário; pago o preço, valerá a sentença como título para o registro do imóvel em nome dos possuidores".

${ }^{86}$ Art. 129 da LPI. Vide nota 52.

${ }^{87}$ Lei ${ }^{\circ}{ }^{5} .648$, de 11 de dezembro de 1970.
} 
Mesmo assim, é de se expressar a vontade legislativa nacional de estabelecer que a marca garante direitos de propriedade ao seu titular, sendo possível, assim, explorá-la (ou não), defendê-la da usurpação de terceiros, e transferi-la a interessados.

Sob o ponto de vista legislativo internacional, os tratados mais importantes não resolvem a natureza da proteção sobre a marca, mas simplesmente afirmam o desejo de reduzir distorções e obstáculos que a Propriedade Intelectual possa vir a sofrer, levando em consideração a necessidade de promover uma proteção eficaz e adequada desses direitos. Isso é o que diz o TRIPs ${ }^{88}$ que visa organizar a proteção à Propriedade Intelectual em um mundo comercial globalizado.

A propriedade, muitas vezes, exerce importante influência na busca pela eficiência econômica, na medida em que ela pode resultar na imposição de direitos perante terceiros, que dela tentem se apoderar injustamente. Assim, o direito de exclusão no campo das marcas é essencial para a proteção de sua distinção perante os concorrentes e os consumidores. Garantir sua eficiência e integridade são deveres dos titulares, que se envolvem em conflitos durante o processo concorrencial.

Mas, o registro de marca confere direito de propriedade a um titular?

Em que pese haver discussão sobre o direito de propriedade sobre o bem físico e seus limites sob a ótica de sua função social, compreende-se que este constitui instituto amplamente analisado e criticado. Entretanto, é necessário visualizar a propriedade sobre bem físico para entender melhor a propriedade sobre o bem intangível.

A propriedade, portanto, consiste em um instituto jurídico de suma importância para o Direito e para a sociedade, e por isso defende-se a imposição de direitos de propriedade aos bens intangíveis por oferecerem direitos mais seguros ${ }^{89}$ para os titulares, ocasionando menos custos de transação e mais eficiência econômica.

\footnotetext{
${ }^{88}$ Decreto $^{\circ} 1.355$, de 30 de dezembro de 1994.

${ }^{89}$ MUELLER, Bernardo, ZYLBERSZTAJN, Decio e SZTAJN, Rachel. Economia dos direitos de propriedade. ZYLBERSZTAJN, Decio e SZTAJN, Rachel, (Orgs). In: Direito \& Economia. Análise Econômica do Direito e das Organizações. $2^{a}$ Tiragem. São Paulo: Campus, 2005. pp. 94/95. O texto traz excelente gráfico explicativo do surgimento dos direitos de propriedade, tomando o exemplo da propriedade
} 
Para o presente estudo, suficiente se faz apresentar diferentes teorias da propriedade, visto que tal instituto definirá o direito de agir dos titulares perante terceiros, seja através da apresentação de pedidos de registro de marca ao INPI ou por uso considerado infrator de direitos.

(a) A teoria do direito natural, perpetuada por $\mathrm{LOCKE}^{90}$, estabelece que o indivíduo possui direito natural à propriedade. "[S]eguindo a argumentação do filósofo inglês, o reconhecimento de um direito absoluto de exploração econômica da criação intelectual seria uma consequência do próprio ato de criação e, neste sentido, um direito natural". 91 Aplicando-se à Propriedade Intelectual, o direito de propriedade das ideias como mero veículo à obtenção de bens de Propriedade Intelectual ${ }^{92}$ geraria o ônus à sociedade de reconhecer e respeitar moralmente tais direitos.

(b) A teoria da remuneração é baseada no direito natural e recebe a adição do elemento econômico. A ideia, se protegida e disponibilizada ao público por meio da publicação, deve gerar direito natural do inventor/autor à remuneração.

(c) A teoria do encorajamento dá origem à tríade incentivo-monopólio-lucro. Revertendo a teoria da remuneração, deve haver incentivo ao desenvolvimento da propriedade para que haja progresso da sociedade. Assim, deve haver criação do incentivo à invenção, partindo dos pressupostos de que o progresso industrial é importante e que as invenções e sua exploração industrial contribuem para esse progresso.

Cláudio BARBOSA, utilizando-se de artigo de Newton SILVEIRA ${ }^{93}$, citou passagem de Marquês de São Vicente a respeito do merecimento dos criadores/titulares em relação à propriedade alcançada por seu esforço e trabalho: "A descoberta ou invenção de

material rural. O gráfico oferece meios para compreensão de que o direito de propriedade seguro nasce da sua própria escassez. É clara a possibilidade de aplicação do presente gráfico à leitura da segurança que a distintividade de uma marca poderá oferecer ao seu titular.

${ }^{90}$ LOCKE, John. Two Treatises of Government. London, 1689.

${ }^{91}$ GRAU-KUNTZ, Karin: Jusnaturalismo e Propriedade Intelectual. In RABPI no 100 . p. 7.

92 Patentes, desenhos industriais, marcas, indicações geográficas, obras intelectuais protegidas por Direito de Autor, incluindo o software, os circuitos integrados e os novos cultivares. A lista não é numerus clausus e não se permite a se estagnar frente ao avanço da sociedade.

${ }^{93}$ SILVEIRA, Newton. Natureza e fundamento do direito do inventor. In Tecnologia, importação e exportação. Série Comércio Exterior vol. 3. São Paulo: CTE, (s.d.). p. 43. 
uma indústria útil ou de seu melhoramento é feito da inteligência e trabalho do inventor, é criação sua e consequentemente sua propriedade. É, pois, justo que a lei segure seus direitos e reprima a violação deles; esse ato, além de ser de justiça, é também de grande vantagem e incentivo econômico; é o meio mais seguro de enriquecer a sociedade de novos descobrimentos, processos, aumento e perfeição de forças industriais". ${ }^{94}$

(d) A teoria do contrato, seguindo ROUSSEAU ${ }^{95}$, considera que a sociedade firma contrato com o indivíduo, que passa a ter o direito exclusivo de explorar a res durante um período determinado. Este por sua vez, a divulga (publica), tornando-a pública possibilitando o acesso à informação por todos. Após a extinção de sua vigência, a res é devolvida à sociedade e se transforma em res communis omnium.

Independentemente da teoria, o instituto da propriedade foi o resultado da análise econômica da escassez, visto que em não havendo delimitação dos direitos de propriedade, haveria tendência natural ao sobre-uso dos bens pelos indivíduos que visam maximizar seu bem estar, levando-os à perda da propriedade pela exaustão da mesma. Garrett HARDIN ${ }^{96}$ chamou o fenômeno de tragédia dos comuns e Fernando ARAÚJO ${ }^{97}$, de tragédia dos baldios.

Ao contrário, em não havendo escassez dos recursos, possível verificar a desnecessidade de delimitação dos direitos de propriedade. Nessa linha, há interessante pesquisa conduzida por Harold DEMSETZ ${ }^{98}$ na análise de tribos canadenses na Península de Labrador, que ocupavam duas regiões com características diferentes. De um lado, a

\footnotetext{
${ }^{94}$ BARBOSA, Cláudio, Op. cit. p. 40.

${ }^{95}$ ROUSSEAU, Jean Jacques. Du Contrat Social: ou Príncipes du Droit Politique. França, 1762.

${ }^{96}$ HARDIN, Garrett. The Tragedy of the Commons. In: Science Magazine, vol. 162, $\mathrm{n}^{\circ} 3859$, pp. 1243/1248, 1968.
}

${ }^{97}$ ARAÚJO, Fernando. A Tragédia dos Baldios e dos Anti-Baldios - O Problema Econômico do Nível Óptimo de Apropriação. Editora Almedina, 2008.

${ }^{98}$ DEMSETZ, Harold. Toward a Theory of Property Rights. In: The American Economic Review, vol.57, $\mathrm{n}^{\circ} 2$, Papers and Proceedings of the Seventy-ninth Annual Meeting of the American Economic Association. pp. 347/359, 1967. “A questão da propriedade privada da terra entre indígenas constituiu um fascínio para os antropólogos. Ele tem sido um dos campos de batalha intelectual na tentativa de avaliar a "verdadeira natureza" do homem sem restrições pelos "artifícios" da civilização. No processo de realização deste debate, a informação foi descoberta que se relaciona diretamente com a tese com a qual estamos agora em causa. $O$ que parece ser aceito como um tratamento clássico e um ponto alto deste debate é livro de memórias de Eleanor Leacock sobre O território de caça Montagnes e o comércio de peles. A pesquisa de Leacock seguiu a de Speck, que tinha descoberto que os índios da Península do Labrador tinham uma longa tradição da propriedade da terra. Este achado estava em desacordo com o que se sabe sobre os índios do sudoeste americano e estudo solicitado à Leacock sobre os Montagnes que habitavam grandes regiões ao redor de Quebec”. Tradução livre do original. 
região, capaz de gerar recursos limitados aos seus ocupantes, passou a ser objeto de divisão de propriedades devido à incerteza do fornecimento de recursos e compelia os indivíduos a se garantirem com espaços próprios de modo a que o fornecimento desses recursos fosse percebido pelo seu próprio esforço. Não seria improvável que, após a delimitação dessas propriedades, o fenômeno da troca começasse a ocorrer. Do outro lado, da região capaz de oferecer recursos suficientes aos indivíduos, sem se preocuparem com a escassez, verificou-se que a delimitação de propriedades não era vista como uma necessidade entre os indivíduos.

LANDES e POSNER ${ }^{99}$ são claros ao dizer que é preciso haver incentivo para que o titular de um bem intangível se assegure que sua exploração seja suficiente para que o trade off valha a pena.

Na medida em que os direitos de Propriedade Intelectual são freqüentemente infringidos por terceiros que não investiram na criação da propriedade (free riders), existe o receio de que, em não havendo segurança jurídica contra a infração, o incentivo à criação estará enterrado. Ao mesmo tempo que a proteção legal contra a infração permite ao criador da propriedade intelectual a cobrança pela disponibilização do bem por um preço

\footnotetext{
${ }^{99}$ LANDES, William M. e POSNER, Richard A. The Economic Structure of Intellectual Property Law. Harvard University Press, 2003. p. 11. "O perigo é exagerado por uma tendência entre análise econômica da propriedade intelectual troca dos direitos entre "incentivo" e "acesso". Pelo fato da propriedade intelectual ser muitas vezes copiável pelos concorrentes que não tenham qualquer obrigação do custo de criar a propriedade, existe o medo de que, sem proteção legal contra a cópia o incentivo à criação de propriedade intelectual será prejudicada. Ao mesmo tempo, a proteção legal contra a cópia, permitindo que o criador da propriedade intelectual para cobrar um preço sobre as cópias (de que seu direito de propriedade faz dele um monopolista) acima de seu custo marginal, impede o acesso a (o uso de) a propriedade intelectual por pessoas que valorizam o que o acesso a mais do que o custo marginal, mas menos do que o preço. Vamos argumentar que para reduzir o problema da propriedade intelectual para esta troca é simplificar muito, ignorar corpos inteiros de leis da propriedade intelectual, nomeadamente o direito da marca e, de pertinência particular a este capítulo, para obscurecer a continuidade jurídica e econômica entre o físico e propriedade intelectual. Não que a troca do incentivo é inexistente ou mesmo sem importância, mas o é muito mais a considerar em uma análise econômica do direito de propriedade intelectual". Tradução livre do original: "The danger is exarcerbated by a tendency among economic analysis of intellectual property rights toa tradeoff between "incentive" and "access". Because intellectual property is often copiable by competitors who have not borne any of the cost of creating the property, there is fear that without legal protection against copying the incentive to create intellectual property will be undermined. At the same time, legal protection against copying, by enabling the creator of intellectual property to charge a price for copies (of which his property right makes him a monopolist) in excess of his marginal cost, prevents access to (use of) the intellectual property by persons who value that access at more than the marginal cost but less than the price. We shall argue that to reduce the problem of intellectual property to this tradeoff is to oversimplify greatly; to ignore entire bodies of intellectual property law, notably trademark law; and, of particular pertinence to this chapter, to obscure the legal and economic continuity between physical and intellectual property. Not that the incentive access tradeoff is nonexistent or even unimportant; but there is much else to consider in an economic analysis of intellectual property law".
} 
superior ao seu custo marginal, impedindo o acesso por indivíduos que dão valor ao bem a mais que o custo marginal, mas inferior ao preço.

PONTES DE MIRANDA ${ }^{100}$, em seu tratado, já criticava aqueles que não aceitavam a idéia de propriedade sobre bens incorpóreos, desde que, "em textos claros, o sistema jurídico recebeu o conceito e a técnica dos direitos reais sobre res incorporales".

GAMA CERQUEIRA afirma que deveria ser considerada como propriedade, não apenas para utilizar uma construção jurídica já conhecida e pronta, mas porque efetivamente as características de domínio da propriedade deveriam ser atribuídas aos bens intelectuais, independentemente dos aspectos típicos da intangibilidade desses bens. ${ }^{101}$

Em julgado pertinente sobre a matéria o $\mathrm{STF}^{102}$ estabeleceu que o direito sobre a marca é de natureza real e que portanto, o direito de propriedade é melhor jungido às marcas. Naquele julgado, o então Ministro Célio Borja decretou que “(...) a garantia constitucional da propriedade das marcas de indústria e comércio e da exclusividade do nome comercial compreende o uso das marcas e do nome. Já porque o direito de usar insere-se no de propriedade., como é de sabença comum, juntamente com o fruir e dispor (...)".

Segundo Denis BARBOSA ${ }^{103}$, que utilizou tal julgado para esposar sua opinião sobre o direito de propriedade sobre a marca, o Ministro Célio Borja assimila o direito de usar ao exercício de uma liberdade de iniciativa. Ou seja, o direito de propriedade de uma marca fundado na concorrência. E continua afirmando que alguns distinguem, além de um monopólio em tensão de concorrência, um direito à marca fundado na própria liberdade de concorrência.

\footnotetext{
${ }^{100}$ MIRANDA, Pontes de. Tratado... § 2018.

${ }^{101}$ CERQUEIRA, João da Gama. Privilégios de invenção e marcas de fabrica e de commercio.

Commentario ao Decreto n. 16.294, de 19 de dezembro de 1923. São Paulo: Revista dos Tribunaes, 1931. p. 59.

${ }^{102}$ STF. Rp 1397 - Julgamento 11/05/1988, DJ de 10/06/88, p. 14401 Ementário do STF - vol-01505.01 p. 00069. RTJ - vol 00125.03 p. 00969 : “Bolsas e sacolas fornecidas a clientela por supermercados. $O$ parágrafo 24 do artigo 153 da Constituição assegura a disciplina do direito concorrencial, pois, a proteção à propriedade das marcas de indústria e comércio e a exclusividade do nome comercial, na qual se incluem as insígnias e os sinais de propaganda, compreende a garantia de seu uso".

${ }^{103}$ BARBOSA, Denis Borges. O Direito Constitucional dos Sinais Distintivos. In: SANTOS, Manoel J. Pereira dos e JABUR, Wilson Pinheiro (Orgs.). Sinais Distintivos e Tutela Judicial e Administrativa. Série GVLaw. São Paulo: Saraiva, 2007. p. 03/28.
} 
A marca quando confere ao seu titular o direito erga omnes de exclusão de terceiros, também oferece a oportunidade de exclusão de parte da concorrência, conferindo monopólio concorrencial sem fazer surgir questionamentos antitrust.

Nessa seara, LANDES e POSNER ${ }^{104}$ afirmam que a maioria dos direitos autorais, marcas e segredos comerciais conferem pouco poder de monopólio. A situação é menos clara sobre patentes, e assim não é de estranhar que os tribunais confundam patente como monopólios legais com os monopólios que têm conseqüências econômicas graves o suficiente para justificar a invocação de proibições antitruste. Esta confusão serve para supor que existe uma tensão inerente entre as leis de Propriedade Intelectual, porque conferem monopólios, e a lei antitruste, que é dedicada a evitar os monopólios.

Para POULLAND-DULIAN, "[o] registro confere ao seu titular direito de propriedade incorpórea, que consiste em um direito exclusivo de exploração ou monopólio de exploração, oponível a todos, mas limitado ao escopo da especialidade". ${ }^{105}$

Cláudio BARBOSA sintetiza que a orientação doutrinária com o respaldo normativo e jurisprudencial é de que natureza jurídica da propriedade intelectual é de propriedade de natureza especial. A natureza jurídica, na visão do autor, é equiparada à propriedade, mas obedece a parâmetros normativos próprios. ${ }^{106}$

Já Elisabeth FEKETE é enfática ao afirmar que a natureza jurídica dos direitos industriais é hoje pacífica na maioria dos países, bem como no Direito brasileiro, como configurando um direito de propriedade. Entre nós, qualifica-se o jus sobre os bens de propriedade industrial como patrimonial, de caráter geral, erga omnes, constituindo propriedade temporária e resolúvel, cujo objeto é imaterial, indivisível, considerado pela lei como bem móvel (art. $5^{\circ}$ da LPI), integrante de estabelecimento. ${ }^{107}$

\footnotetext{
${ }^{104}$ LANDES e POSNER. Op. cit. p. 374.

${ }^{105}$ POULLAND-DULIAN, Fréderic. Droit de La Propriété Industrielle. Paris: Montchrestien, 1999. p. 601. Traduzido livremente de: "[l']enregistrement confere au titulaire um droit de propriété incorporel, qui consiste em um droit exclusif d'exploitation ou monopole d'expoloitation, opposable à tous, mais limite au cadre de la spécialité".

${ }^{106}$ BARBOSA, Cláudio, Op. cit. p. 46.

${ }^{107}$ FEKETE, Elisabeth Kasznar. O regime jurídico do segredo de indústria e comércio no Direito brasileiro. Rio de Janeiro: Forense, 2003, p. 130.
} 
Acrescenta a autora que as únicas diferenças sobre a propriedade comum, o caráter incorpóreo do bem e a temporalidade do direito não são peculiaridades que descaracterizam a essência do direito. ${ }^{108}$

E Newton SILVEIRA decreta que "o conteúdo é o da propriedade e uso exclusivo do sinal para assinalar as mercadorias, produtos ou serviços do titular distinguindo-os de outros idênticos". ${ }^{109}$

Dessa forma, passados os pressupostos legais, resume-se que a propriedade sobre uma marca nasce com a decisão de concessão do registro pelo INPI após o devido processo administrativo. Em que pesem os comentários sobre a ocupação de um sinal préexistente, tal ato não gera direitos de propriedade sobre a marca, tal como ocorre na propriedade mobiliária comum, através do usucapião. Ademais, o direito de propriedade sobre um signo distintivo recai sobre o direito de uso do mesmo em uma atividade empresária, diferentemente da propriedade comum do Código Civil.

Por fim, anota-se que o direito sobre a marca é precário até completarem-se 05 (cinco) anos após a decisão do INPI de conceder o registro para a mesma, conforme preceituam os artigos 169 e 174 da LPI. Findo esse prazo prescricional, a propriedade sobre a marca se aproxima da propriedade comum. ${ }^{110}$

Passadas essas páginas, parece assente para alguns autores nacionais de peso ${ }^{111}$ que, apesar da discussão sem fim sobre a natureza jurídica da marca, a alcunha de propriedade lhe cai muito bem.

\subsection{Críticas à natureza de propriedade}

Há críticas bastante eloqüentes sobre a natureza jurídica das marcas, sobretudo quando da análise da relação jurídica personna - res incorporale. Historicamente, desde o

\footnotetext{
${ }^{108}$ FEKETE. Op. cit. p. 133. Cita Luiz Leonardos em A natureza jurídica sobre a invenção patenteada. Dissertação de mestrado. Rio de Janeiro: Universidade Gama Filho, 1983. p. 102/103.

${ }^{109}$ SILVEIRA, Newton. Licença... Op. cit. p. 36.

${ }^{110}$ BARBOSA, Denis. Proteção das marcas... Op. cit. p. 258.

${ }^{111}$ Ruy Barbosa, J. X. Carvalho de Mendonça, Pontes de Miranda, João da Gama Cerqueira.
} 
final do século XVIII, mais precisamente durante a revolução burguesa, reinou a hipótese de que os direitos sobre os bens incorpóreos seriam direitos de propriedade.

A construção histórica legislativa, aliás, fortalece tal conceito ao dispor dos direitos de Propriedade Intelectual como propriedade. Tanto a Constituição Federal de $1988^{112}$ como a Lei da Propriedade Industrial vigente ${ }^{113}$, categorizam o direito sobre a marca como propriedade.

Todavia, diversas críticas a essa caracterização vêm sendo postadas pelos juristas desde o século XIX como o senador belga Edmond PICARD, passando por Clóvis BEVILAQUA $^{114}$, e até mais recentemente por José de Oliveira ASCENSÃO ${ }^{115}$, Carlos Alberto BITTAR ${ }^{116}$ e Silmara CHINELLATO ${ }^{117}$. Praticamente todos afirmam que nossa matéria teria melhor alcunha com a expressão "direitos intelectuais".

Tal expressão foi originalmente cunhada por PICARD ${ }^{118}$ em 1877, quando propôs a nova divisão dos elementos fundamentais dos direitos subjetivos, ao propor essa quarta categoria. A análise de Picard foi motivada pela divisão imposta pelo Direito Romano $^{119}$, que apesar de compreenderem o conceito de res incorporea, para eles não

\footnotetext{
${ }^{112}$ Artigo $5^{\circ}$ inciso XXIX da CF/88.

${ }^{113}$ Art. 129 da LPI. Vide nota 52.

${ }^{114}$ BEVILÁQUA. Op. cit. p. 80.

${ }^{115}$ ASCENSÃO, José de Oliveira. Direito intelectual, exclusivo e liberdade. In: RABPI v. 59, pp. 40-49. Rio de Janeiro: ABPI, jul/ago 2002.

${ }^{116}$ BITTAR, Carlos Alberto. Direito de Autor na Obra Publicitária. 1ª ed. São Paulo: RT, 1981.

${ }^{117}$ CHINELlato, Silmara: Direitos de Autor e de Personalidade: Reflexões à luz do Código Civil. Tese de Titularidade para a cadeira de Direito Civil da Faculdade de Direito da Universidade de São Paulo. São Paulo: USP, 2008.

${ }^{118}$ PICARD, Edmond. O Direito Puro. $2^{\mathrm{a}}$ Ed. Progresso: Salvador, 1954. § 45, pp. 99/100. “É por instintivamente haver tido o sentimnto destas verdades sociais, - ou por não haver sabido compreender que certos direitos podem ter por objeto concepções do intelecto, - ou, ainda, porque esta segunda razão apenas tem servido apra disfarçar a primeira sob uma forma secundária (como acontece muitas vezes com a efermidade humana) que os romanos não incluíram no seu Direito (quão monumental apesar disso!) o que cada vez mais se costuma chamar os Direitos Intelectuais, e que persistiu, durante tão largo espaço, esta manfeira de ve? Só quasi de há século e meio a esta parte é que se viu depontar e insensivelmente precisarse a noção de que as invenções e descobertas industriais, as obras de arte e de literatura, os modelos e desenhos de fábrica, as marcas de comércio e as denominações, os planos, as cartas missivas, - tudo o que tem uma existência puramente intelectual, própria e original, antes da sua expressão e da sua realização em corpos materiais, máquinas, quadros, estátuas, livros, móveis, estofos, papel, - podia, sob essa forma psíquica, contanto que dotados de novidade, tornar-se objetos de direitos de uma natureza especial".

${ }^{119}$ MARKY, Thomas. Curso elementar de Direito Romano. São Paulo: Saraiva, 6 a ed. 1992, p. 41: "Por razões de ordem profana, eram consideradas fora do comércio (res extra commercium humani iuris) as coisas comuns a todos (res communis omnium), isto é, as indispensáveis à vida coletiva ou a ela úteis, como o ar, a água corrente, o mar e as praias".
} 
existia o conceito da separação entre ideia, elemento originado pela criação, e o objeto que substancia a mesma criação; tampouco havia uma valoração específica do bem incorpóreo. Os "bens imateriais" eram definidos simplesmente pela negação da tangibilidade, enquanto os outros bens eram tangíveis, tinham corpo. No conceito romano de "imaterial" não existe qualquer componente de criativiadde ou ação, apenas existe (ou não) um corpo. ${ }^{120}$

Uma das críticas comuns à caracterização da tutela sobre bens intelectuais como propriedade consiste na manutenção da integridade da propriedade material comum mesmo que a mesma seja utilizada ou não para fins privados ou públicos, comerciais ou não. Como a propriedade da marca é uma exclusividade do uso do signo no mercado, e mais, num mercado designado, não existe propriedade sobre o signo em si mesmo e, especialmente, não se veda o uso de terceiros do mesmo signo num contexto diverso, desde que tal uso não eroda ou elimine o uso regular da propriedade no seu campo próprio. ${ }^{121}$

Outra crítica pertinente à caracterização do direito de propriedade sobre a marca, consiste nas regras impostas pela LPI para adquirir registros a terceiros. É que o cessionário precisa cumprir com requisitos específicos do artigo 128 da referida lei para que possa intitular o registro da marca. O requisito do artigo 135 da LPI $^{122}$ também é específico, tendo em vista que impõe que a cessão deva ocorrer em relação a todas as marcas idênticas ou semelhantes que designem produtos ou serviços idênticos ou semelhantes. Tal regra serve para proteção do consumidor e para resguardo da unicidade da titularidade. Na propriedade comum, apesar da possibilidade de imposição de requisitos contratuais, não ocorre tais especificações legais.

Como dito acima, mesmo que a propriedade material não seja utilizada, a propriedade se mantém. Já na propriedade sobre a marca, caso esta não seja utilizada a partir de 05 (cinco) anos contados da sua concessão pelo INPI, estará sujeita a processo de caducidade por terceiros interessados. A caducidade versa sobre a possibilidade de extinção de um registro de marca por falta de uso, de acordo com o artigo 142 da LPI.

\footnotetext{
${ }^{120}$ BARBOSA, Cláudio. Op. cit. p. 22/23.

${ }^{121}$ BARBOSA, Denis. Proteção das marcas... Op. cit. p. 256.

${ }^{122}$ Art. 135 LPI. “A cessão deverá compreender todos os registros ou pedidos, em nome do cedente, de marcas iguais ou semelhantes, relativas a produto ou serviço idêntico, semelhante ou afim, sob pena de cancelamento dos registros ou arquivamento dos pedidos não cedidos".
} 
Esse caráter finito da extensão do direito sobre os bens intelectuais é atribuído por todos os países do mundo. É bem verdade que a imposição de prazos na chamada Propriedade Intelectual faz parte do exercício do próprio sistema embasado precipuamente no princípio da recompensa, na qual estabelece que o titular/criador do bem incorpóreo recebe o privilégio do direito de uso exclusivo temporário e em troca, devolve a informação à sociedade para que possa continuar a se desenvolver. ${ }^{123}$

Essa característica finita da Propriedade Intelectual inaugura os comentários do artigo 142 pela colocação da faculdade ofertada ao titular do bem de Propriedade Intelectual de abrir mão de sua informação exclusiva em prol do domínio público, seja pelo abandono do direito de uso exclusivo (inciso I) como pela renúncia expressa que deve ser manifestada ao INPI através de petição própria. ${ }^{124}$

Outra crítica ao direito de propriedade repousa na relação entre sujeito e criação intelectual, cujo ato criativo é pessoal ${ }^{125}$ e por isso, rejeita-se a hipótese de se conceder direito real sobre a coisa incorpórea, nascida de processo criativo pessoal do autor.

Mais uma crítica da doutrina é a imposição de limite relativo à atividade comercial do bem incorpóreo tido como propriedade. Veja-se que a proteção às marcas se dá de acordo com a atividade comercial designada como o signo e dentro desses limites e das áreas de relação ou afinidade com essa atividade, o titular da marca terá o direito de fazer valer seus direitos perante terceiros, incluindo o poder de excluí-lo do uso.

No sentir de KOHLER, existem pontos de interseção entre a propriedade comum e a intelectual, porém "ainda que se pudesse encontrar uma semelhança jurídica,

\footnotetext{
${ }^{123}$ A questão do desenvolvimento social e tecnológico pode ser encarado, a um modo de ver particular, ao propósito da função social da propriedade intelectual instituída pela Constituição Federal de 1988 em seu artigo $5^{\circ}$ XXIX.

${ }^{124}$ Se tal petição for apresentada por procurador, o mandato deve conter poderes especiais de renúncia de registros em nome do mandante, conforme preceituado no Manual do Usuário do INPI instituído pelo Ato Normativo $n^{\circ} 160 / 2001$.

${ }^{125}$ GAMA CERQUEIRA. Op. cit. vol. I, p. 78: “Clóvis Beviláqua, que mais profundamente estudou este assunto seguiu a princípio a mesma doutrina que Tobias Barreto: 'Em vista da face dupla do direito autoral, alguns pensadores não só lhe recusam o nome de propriedade, como o afastam, na classificação, do grupo dos direitos reais, porque acham que a relação é preponderante nesse direito, que é primitiva e a mais intima”.
} 
não é lícito agrupar os dois pontos sob o mesmo conceito, pois caso contrário, o que a lei positiva estabelece para um seria simplesmente aplicado também para o outro". ${ }^{26}$

A propriedade das marcas se exerce na concorrência, mas com as características peculiares que decorrem do fato de essa concorrência se encontrar mediada, ou ampliada, por um fluxo simbólico que ultrapassa o produto ou serviço assinalado. ${ }^{127} \mathrm{Em}$ uma propriedade plena, tal limite não lhe é imposto, sendo que o bem poderá ser explorado da melhor forma que convier ao seu possuidor legal.

${ }^{126}$ KOHLER, Joseph. Manualle delle Privative Industriali. Milão: Societá Editrica Libraria, 1914. pp. 15/16.

${ }^{127}$ BARBOSA, Denis. Proteção das marcas... Op. cit. p. 197. 


\section{Capítulo II \\ AS NOÇÕES DE INTEGRIDADE}

\section{O verbete}

Integridade, do latim integritate, significa a qualidade de alguém ou algo de ser íntegro, de conduta reta, honroso, ético, educado, imparcial (visto que está sendo íntegro a algo ou alguém. O que é íntegro mostra-se inocente e puro na presença dos mal intencionados. $^{128}$

São exemplos de integridade moral e corporal: a vida íntegra, a integridade física dos bens sociais e individuais, integridade da honra e da fama, a integridade da intimidade pessoal, do nome, da imagem e dos sentimentos. É indiscutível a admissão da existência de determinados bens da personalidade e sua integridade, portanto, esta coaduna com o respeito, e este com a moral, e, quem tem moral, é íntegro.

Assim, Aurélio Buarque de Hollanda FERREIRA define o verbete integridade como "1. Qualidade de íntegro. 2. Caráter. daquilo a que não falta nenhuma das suas partes. 3. Estado são, de inalterável. 4. Fig. Retidão. , honradez; pureza intacta”. ${ }^{129}$

Já Antônio HOUASSIS expõe que a palavra integridade também pode ser chamada de "[i]nteireza, plenitude, totalidade, unidade" no sentido material das coisas. Sob o ponto de vista da honestidade, a palavra integridade também é colocada como "[d]ignidade, honradez, imparcialidade, lhaneza, lisura, probidade, retidão, virtude". No caso do campo da inocência, HOUASSIS define integridade como "[c]andura, castidade, ingenuidade, pudor, pureza, virgindade". $\mathrm{Na}$ ideia de intangibilidade, integridade é analisada como "[i]natingibilidade, incolumidade, inta(c)tilidade". E por fim, na esfera da sanidade, integridade é também comentada como "[b]em-estar, salubridade". ${ }^{130}$

\footnotetext{
${ }^{128}$ Wikipedia (http://pt.wikipedia.org/wiki/Integridade). Acessado em 05/01/2011.

${ }^{129}$ FERREIRA, Aurélio Buarque de Hollanda. Novo Dicionário Aurélio da Língua Portuguesa. $2^{\mathrm{a}}$ ed. Rio de Janeiro: Nova Fronteira, 1997. p. 955.

${ }^{130}$ HOUASSIS, Antônio. Dicionário de Sinônimos e Antônimos Houassis, 2 a edição. São Paulo:

Publifolha, 2008. p. 423.
} 
Luiz Antônio SACCONI anota que integridade é "[Q]ualidade, condição ou estado do que é íntegro, inteiro ou completo; inteireza" ou "[C]ondição perfeita de uma coisa; inteireza". E ainda SACCONI ensina que integridade significa "[A]titude íntegra, honrada e digna de respeito; retidão ou inteireza moral; honestidade absoluta". ${ }^{131}$

Outras definições de integridade podem ser encontradas em outros idiomas oferecendo, sob outras perspectivas do verbete, outras chances de interpretação à luz do objeto do presente estudo. Por exemplo, o Diccionario Esencial de la Lengua Española ensina que integridad é o "[E] stado que está completa ou tem todas as suas partes". 132

Nota-se por essa pequena demonstração linguística, que a palavra integridade possui conotações material e moral e que no presente estudo, pretende-se evoluir com essas definições objetivando demonstrar que a marca, um bem intelectual, é composta por tais características de completude, unidade, lisura e probidade que os dicionários trazem.

Como expressado por BITTAR no que tange às características de um bem, “[D]efluem (...) diferentes e múltiplos direitos, de cunho moral ou patrimonial, relacionados ao liame pessoal do criador à obra (direito de paternidade; de integridade da obra; direito de nominação e outros), ou à sua exploração econômica (direitos de representação e de reprodução da obra, donde o autor retira os respectivos proventos)". 133

Apesar da conotação autoral de suas palavras, os ensinamentos de BITTAR podem ser aplicados em outros cenários da Propriedade Intelectual. E especificamente sobre a marca, pretende-se demonstrar que tal bem intelectual comporta tanto aspectos morais (reputação do seu titular) como materiais (distintividade e distinção).

\footnotetext{
${ }^{131}$ SACCONI, Luiz Antônio. Grande Dicionário Sacconi da Língua Portugesa Comentado, Crítico e Enciclopédico. São Paulo: Nova geração, 2010. p. 1186. Do original: “[E]stado de lo que está completo o tiene todas sus partes". "[H] onradez y reclitud en la conducta".

${ }^{132}$ Diccionario Esencial de la Lengua Española. São Paulo: WMF Martins Fontes, 2010. p. 422.

${ }^{133}$ BITTAR, Carlos Alberto e BITTAR FILHO, Carlos Alberto. Op. cit. p. 97.
} 


\section{A integridade enquanto bem moral e ético.}

Como bem demonstrado pelos dicionários, a integridade possui forte conotação moral, sendo que tal conceito constitui elemento balizador das relações comerciais entre concorrentes. Não à toa que as regras de concorrência primam pela lisura dos atos comerciais entre os agentes econômicos.

Antonio COSTELLA anota que "[A] boa reputação, construída ao longo de inumeráveis anos de comportamento honesto, é necessária para a vida social profícua de uma pessoa, que, na estima dos membros da coletividade, encontra apoio para levar avante suas iniciativas. Por isso, é óbvio que a redução dessa estima social, por causa de contumélias assacadas injustamente e derruidoras do bom nome, será entrave ao êxito pessoal, com reflexos sensíveis, inclusive, na vida econômica do atingido". ${ }^{134}$

No sentido do presente estudo, a integridade moral é analisada como uma característica essencial de sobrevida da marca e dos efeitos emanados pelo seu uso. A integridade material de uma marca afeta a reputação do seu titular ou utente, o qual sofre com as informações falsas e outras vezes, decorrentes das intenções legítimas da sociedade, que são divulgadas a respeito dos seus produtos ou serviços.

Natural, portanto, é a divulgação autêntica de informações a respeito dos produtos ou serviços circulantes no mercado. Aliás, nada pode fazer o titular ou utente de uma marca que, ao disponibilizar um produto de baixa ou discutível qualidade, vê seu signo distintivo em comparações com outros, ou em resenhas analíticas conduzidas por profissionais de boa-fé e promovidas por veículos de comunicação.

Não há, dessa forma, como disfarçar ou esconder as verdades do mercado. Todavia, apesar da necessidade de circulação das informações, e mesmo levando em consideração a verdadeira função do princípio da veracidade, essas marcas amarguram queda de reputação e por consequência, diminuição de vendas e insatisfação dos consumidores. Em que pese a reputação do fabricante ser verdadeira e o mercado resolver espontaneamente tal situação, a integridade moral do agente econômico resta abalada.

${ }^{134}$ COSTELLA, Antônio. Direito das Comunicações. São Paulo: RT, 1976. p. 258. 
Carlos Alberto BITTAR traz à vida moderna a noção da honra, que pode ser aplicada à vida comercial das empresas por analogia, afirmando que "[p]or força dessa multifariedade da vida, sob vários aspectos pode ser enfocada a reputação da pessoa, falando-se, então, em: honra civil; honra comercial; honra científica; honra profissional; honra política; honra artística e outras, todas protegíveis no plano do direito em questão". 135 Os comentários de BITTAR se inclinam ao Direito de Autor, porém acaso utilizasse os dizeres do autor para aplicação dos conceitos à empresa, talvez alcançar-seiam alguns pontos de interseção entre esses dois campos do Direito.

Tanto é possível que BITTAR reconhece que tais princípios podem ser aplicados a pessoas jurídicas anotando que "[O] relevo do reconhecimento quanto a pessoas jurídicas reside na necessidade de amparar-se a empresa, em função de atentados injustos de concorrentes". ${ }^{136}$ Refere-se o autor aos atos de concorrência desleal insculpidos pela Propriedade Industrial e fulcrados pelos incisos do artigo 195 da LPI.

Note-se que, atualmente, a atividade empresarial possui diversos campos de atuação simultâneos e que, a todo momento, a atividade pode sofrer revés em áreas antes somente analisadas sob o prisma dos direitos da personalidade. É o caso, por exemplo, da honra comercial (e.g. deslealdade comercial por informação falsa sobre produtos/serviços), científica (e.g. sabotagem industrial alterando resultados de pesquisas científicas), política (e.g. atividade empresarial que resulta em dano ao meio ambiente) e artística (e.g. plágio praticado por artista contratado a exercer função criativa).

Abalos como esses ocasionam desequilíbrio quanto à integridade moral das empresas que, cada vez mais precisam cumprir com funções plurais em suas atividades, devolvendo benefícios em contrapartida à sociedade, como num contrato tácito.

\footnotetext{
${ }^{135}$ BITTAR, Carlos Alberto. Os Direitos da Personalidade. Rio de Janeiro: Forense Univesitária, 1989. p. 126/127).

${ }^{136}$ BITTAR. Op. cit. p. 129.
} 


\section{A integridade, Schechter e a marca}

As definições linguísticas emprestam seus ensinamentos à interpretação da integridade da marca que é mais do que a simples proteção contra a diluição de marcas famosas. Por isso, faz-se necessário examinar o conceito amplo de integridade de modo a compreender o quê e como tal conceito pode influenciar as consequências do uso da marca pelo titular e por terceiros.

O conceito de unicidade ${ }^{137}$ da marca é o ponto de partida para o estudo da integridade que pretende-se no presente estudo. E tal conceito foi bem colocado por SCHECHTER quando da apresentação de seu trabalho à Harvard Law Review em 1927. O seu trabalho é de suma importância para a amplitude de entendimento de integridade, pois critica o conceito primário da função da marca que é distinguir produtos ou serviços de outros da mesma atividade comercial.

Por unicidade, SCHECHTER define que a marca precisa ser única e se deixar de sê-lo corre-se o risco da mesma tender ao uso comum da língua. Ele expressa tal entendimento com clareza ao explicar que "[S] uperficialmente, pode parecer ser um divisor de águas dizer que enquanto o consumidor não sabe a fonte específica de um produto de marca registrada, ele, no entanto, sabe que os dois produtos, tendo a mesma marca, emanam de uma única fonte". ${ }^{138}$ Percebe-se, então, que se o consumidor não souber a diferença entre duas fontes com a mesma marca, poderá levar o que não quer originalmente. Essa é a verdadeira noção do risco de confusão.

O autor utiliza em seu artigo palavras e expressões como "dispersão", "perda do poder de venda", "distintiva", "individualidade", "única", "singularidade" para explicar que o ponto central da proteção à marca é a sua integridade e não a designação de uma origem.

\footnotetext{
${ }^{137}$ No Brasil, o termo uniqueness é traduzido comumente pelos autores nacionais como unicidade, que como característica conquistada pela marca, ditará o seu caráter de integridade material.

${ }^{138}$ SCHECHTER. Op. cit. p. 817. Tradução livre do original: "Superficially it may appear to be very fine hair-splitting to say that while the consumer does not know the specific source of a trademarked article, he nevertheless knows that two articles, bearing the same mark, emanate from a single source".
} 
Décadas depois, SCHECHTER continua atual e seus ensinamentos reverberam tanto nos Estados Unidos como no Brasil.

Jane C. GINSBURG, Jessica LITMAN e Mary L. KEVLIN escreveram que "[A] teoria de Schechter... decorre de uma premissa simples, se não dita: os titulares de marcas sofrem prejuízo sempre que outros usem suas marcas sem permissão. Para Schechter, esta premissa não só resolveu o problema dos 'produtos não-concorrentes', mas também compensou empresas por fazerem investimentos em palavras transmutadas, frases e símbolos em agentes de "poder de venda,", ${ }^{139}$ As autoras continuam interpretando SCHECHTER dizendo que "[U]ma leitura próxima da Base Racional [parte do título do artigo 'Rational Basis of Trademark Protection'] indica que unicidade... consiste na clássica distintividade da marca mais alguma outra coisa". ${ }^{140}$

Seguindo os ensinamentos de SCHECHTER, Denis Borges BARBOSA conclui que "[U]nicidade" vem a ser aqui a inexistência de qualquer outro signo contrastante, sem se apurar a especialidade, ou seja, as lindes da concorrência" "141. Seguindo o mesmo entendimento, unicidade, no entender de DANNEMANN, "[g]arante que o consumidor terá somente a imagem desta marca na mente, pois não existe nenhuma outra marca que se assemelhe." ${ }^{142}$

Liliane RORIZ também analisa a unicidade preocupada com a experiência do consumidor quanto à identificação de uma determinada marca. Ela aplica a definição de

\footnotetext{
${ }^{139}$ GINSBURG, Jane C.; LITMAN, Jessica; KEVLIN, Mary L. Trademark and unfair Compettion Law. Cases and materials. 4th Edition. Foundation Press. New York, 2007. p. 614. Tradução livre do original: "Schechter ['s] ... theory would rest on a simple, if unspoken, premise: owners of qualifying trademarks suffered injury whenever others used those marks without permission. For Schechter, this premise not only solved the 'non-competing goods' problem, but it also compensated companies for making the investments that transformed words, phrases, and symbols into agents of 'selling power'".

${ }^{140}$ GINSBURG, Jane C.; LITMAN, Jessica; KEVLIN, Mary L. Op. cit. p. 614. Tradução livre do original:

"A close reading of Rational Basis indicates that the uniqueness... consisted of classic trademark 'distinctiveness' plus something more".

${ }^{141}$ BARBOSA, Denis Borges. Da aplicação da regra da especialidade aos nomes de empresa. Disponível em http://www.denisbarbosa.addr.com/arquivos/novidades/especialidadeaosnomes.pdf. Acessado em 10/08/2012. p. 1.

${ }^{142}$ DANNEMAN, Siemensen Bigler \& MOREIRA, Ipanema. Comentários à lei de propriedade industrial e correlatos. Rio de Janeiro, São Paulo: Renovar, 2005. p. 260.
} 
unicidade como "[q]uanto menos marcas semelhantes existirem no mercado, mais o consumidor se lembrará daquela marca". 143

SCHECHTER demonstra sua preocupação com o consumidor nas mesmas linhas dos autores acima quando escreve que "[Q] uanto mais distintiva e única a marca, mais profunda é a sua impressão na consciência do público, e maior é a necessidade de sua proteção contra usurpação ou dissociação do produto em particular em relação com o qual ele tem sido usado". 144

Assim é que uma marca quando munida de todos os requisitos de validade merece ser revestida de um caráter formador de direitos e consequentemente, capaz de se impor perante terceiros: a integridade.

A integridade/unicidade é, assim, o "corpo" da marca que a protege de usurpações comerciais e atitudes reprováveis no sentido moral. Metaforicamente, o "corpo" que protege a marca pode se deteriorar e enfraquecer. Esse "corpo" sofre variações de acordo com a sua utilização tanto por seu titular como por terceiros, incluindo competidores, consumidores e veículos de comunicação.

A integridade de uma marca denota todas as capacidades de proteção que uma marca pode utilizar perante terceiros. Dessa forma, quanto maior a integridade material, maior a possibilidade da marca ser considerada única ${ }^{145}$ e assim, fazer valer seu direito de uso exclusivo contra outras que visam a diminuir ou desgastar essa integridade.

\footnotetext{
${ }^{143}$ ALMEIDA, Liliane do Espírito Santo Roriz. A distintividade como uma função dinâmica da marca: o registro marcário, a degenerescência e o significado secundário". In Anais do XXVI Seminário Nacional da Propriedade Intelectual da ABPI 2006.

${ }^{144}$ SCHECHTER. Op. cit. p. 825. Tradução livre do original: "The more distinctive or unique the mark, the deeper is its impress upon the public consciousness, and the greater its need for protection against vitiation or dissociation from the particular product in connection with which it has been used".

${ }^{145}$ Jane C. GINSBURG, Jessica LITMAN e Mary L. KEVLIN escreveram no mesmo sentido: "Para ter certeza, uma marca (e, portanto, diluível) única não possui apenas uma associação a um produto. Marcas únicas são altamente distintivas também, o que as torna capazes de identificar uma única fonte, se anônima". Tradução livre do original: "To be sure, a unique (and therefore dilutible) trademark does not possess only a product association. Unique trademarks are highly distinctive as well, which makes them able to identify a single, if anonymous, source”. In GINSBURG, Jane C.; LITMAN, Jessica; KEVLIN, Mary L. Op. cit. p. 617.
} 


\section{Capítulo III}

\section{A MARCA}

\section{Evolução histórica nas sociedades.}

A designação anglo-saxônica brand tem a sua origem no antigo escandinavo brandr. O seu significado era literalmente associado ao ato de queimar e foi nesse contexto que os saxões adotaram esse termo. A utilização da designação "marca" (brand) passou a estar associada ao ato ou efeito de marcar. Eram desta forma "marcadas" as cabeças e peças de gado com o objetivo essencial de identificar a propriedade e posse de bens materiais, permitindo aos criadores de gado distinguirem os seus animais. Uma vantagem que valorizava os criadores mais conhecidos pela qualidade do seu gado que começavam a ter a sua marca mais reconhecida e, consequentemente, mais procurada nas trocas comerciais.

Newton SILVEIRA comenta que as marcas de fogo do gado, utilizadas no Egito há 2 mil anos a.C., tinham por função tão somente estabelecer a propriedade dessas coisas. Do mesmo modo, as marcas em pedras destinadas às edificações e às pirâmides do Egito de 6 mil anos atrás tinham a função de identificar as pedreiras de origem desses materiais. Assim, também os artífices apunham suas marcas às pedras para certificar o cumprimento de suas quotas de produção. Tais marcas de pedras também foram encontradas no Peru, nas culturas pré-incas e incas. ${ }^{146}$

A história da marca tem origem ainda mais distante, como nas civilizações da Grécia e Roma antiga. Nesse tempo, era hábito deixar impressões na base das peças de olaria e cerâmica. Estas marcas podiam ser impressões digitais ou pequenos símbolos básicos como estrelas ou cruzes.

Uma curiosidade do passado das marcas refere à Bakers Marking Law publicada no ano de 1266 que exigia a todos os padeiros a colocação da sua marca

\footnotetext{
${ }^{146}$ SILVEIRA, Newton. A Propriedade Intelectual e a nova Lei da Propriedade Industrial (Lei $\mathbf{n}^{\mathbf{0}}$ 9.279/1996). São Paulo: Saraiva, 1996. p. 103.
} 
específica em todo o pão que vendiam, com a finalidade de identificar aqueles que maliciosamente tentassem vender pão com um peso inferior ao que a lei permitia.

Newton SILVEIRA ${ }^{147}$ conta que certos sinais distintivos eram utilizados pelos comerciantes desde que existe o comércio. Com a formação do Direito Comercial, no fim da Idade Média, alguns sinais já eram protegidos sem necessidade de lei especial: os nomes dos comerciantes e das sociedades comerciais, os títulos de estabelecimento e as insígnias comerciais.

Cláudio BARBOSA, citando FRANCESCHELLI, comenta que os sinais distintivos sempre estiveram presentes nas sociedades antigas dada a necessidade de identificação da produção artesanal ou bens pessoais, todavia as características dos institutos jurídicos relativos aos sinais distintivos como conhecemos somente começaram a se desenvolver com as corporações de ofício. ${ }^{148}$

Ao longo dos séculos XVII e XVIII, o volume de produção de fina porcelana, mobiliário e tapeçaria que essencialmente era produzido nas oficinas e indústrias artesanais, francesas e belgas, veio a ampliar a utilização das marcas como uma forma de marcar a origem e a qualidade dos produtos. Entretanto, sob os auspícios dos feudos e depois, das monarquias, os detentores do direito de uso das marcas não eram titulares de uma propriedade.

Até o final do século XVIII, o direito sobre as inovações pertencia aos monarcas que consentiam com seu uso, mantendo a titularidade desses direitos. Eram os chamados privilégios. Com a queda da monarquia, um novo modelo surgia e agora, os direitos sobre as inovações eram garantidos aos antigos súditos, hoje artesãos ou comerciantes. Mais do que privilégios, as inovações passaram a criar um poder de exclusão daqueles que não pertenciam às corporações. Estas passaram a comandar as invenções possibilitando o controle dos meios de produção, estoque, demanda e preço.

Cláudio BARBOSA, citando SCHECHTER, conclui que, com o passar do tempo, o que era uma garantia do artesão passou a ser atrativo, um diferencial do produto,

\footnotetext{
${ }^{147}$ SILVEIRA, Newton. A Propriedade Intelectual... Op. cit. p. 88.

${ }^{148}$ BARBOSA, Cláudio, Op. cit. p. 27.
} 
adicionando uma função mercadológica de ligação entre produto e clientela. ${ }^{149}$ Continua o autor informando que com a crescente facilidade de comunicação e comércio, paralelamente ao poder conquistado pelas invenções, e com a circulação de livros, torna-se ainda mais importante a identificação dos fabricantes e dos artesãos que pertenciam às corporações de ofício. Particularmente, com o fim das limitações das atividades empresariais, a importância dessas identificações crescia, pois assegurava que o melhor artesão poderia vender e cobrar mais por seu produto. ${ }^{150}$

Newton SILVEIRA comenta que praticamente inexistia competição industrial antes da Revolução Francesa, sendo que o regime de corporações de ofícios e de monopólios garantidos por decretos reais vigente na Europa, cerceava quase completamente a possibilidade de concorrência. ${ }^{151}$

O resultado jurídico final dos bens intelectuais antes da Revolução Francesa era equivalente a uma concessão governamental, não a uma propriedade, pois o Estado concedia o "privilégio", enquanto após a Revolução Francesa, especialmente, a concessão passou a ser um direito.

No fim do século XVIII, as marcas passam a outro patamar de importância, quando a propriedade intelectual se consolidou - como resultado da Revolução Francesa e da extinção das corporações de ofícios, duas espécies de criadores foram contempladas pelas primeiras leis: o autor no campo das artes (direito de autor) e o autor no campo da indústria (direito de inventor). ${ }^{152}$

Não há dúvidas de que a marca passou a ser almejada quando os direitos sobre ela passaram a ser oferecidos aos industriais e comerciantes como estímulo ao desenvolvimento. É certo que a sociedade passou por diversas mudanças e aprimoramentos nos últimos 200 anos, sendo a Revolução Francesa o principal fato histórico responsável pela transformação da sociedade da produção para a sociedade da informação.

\footnotetext{
${ }^{149}$ BARBOSA, Cláudio, Op. cit. p. 28.

${ }^{150}$ BARBOSA, Cláudio, Op. cit. p. 27.

${ }^{151}$ SILVEIRA, Newton. Curso de Propriedade Industrial. $2^{\mathrm{a}}$ edição revista e ampliada. São Paulo: RT, 1987. p. 14.

${ }^{152}$ SILVEIRA. A Propriedade Intelectual... Op. cit. p. 85.
} 
Todavia, é essencialmente a partir do século XIX (com a revolução industrial) que a utilização das marcas passa a fazer parte do cotidiano das indústrias e do comércio. Sobretudo com o advento da Convenção da União de Paris ${ }^{153}$, em 1883, as marcas deixam de ser meros sinais individualizadores de artesãos e passam a constituir verdadeiros signos distintivos de corporações internacionais quando a produção e comercialização em massa assim começavam a se impor. Ainda hoje existem marcas datadas do século XIX, como COCA-COLA, QUAKER, GILLETTE e HEINZ.

É curioso notar que a conceituação ideológica da propriedade intelectual foi alicerçada pelos juristas e economistas do século XIX, pois nessa época a denominação e o conceito de privilégio, que identificavam até então tais direitos, passaram a ser considerados propriedade, com todas as conotações positivas e negativas que o termo, já naquele momento, acarretava. ${ }^{154}$ Newton SILVEIRA ${ }^{155}$ arremata dizendo que a marca evoluiu da assinatura do produtor a um sinal que vai atuar diante dos consumidores para identificar uma procedência, aposta em um produto oferecido em concorrência.

Nesse sentido, Cláudio BARBOSA comenta que, em meados do século passado e nas décadas seguintes à Segunda Gerra Mundial os parques industriais refletiam o poderio de um Estado: quanto maior o número de siderúrgicas, indústrias e instalações industriais, maior a capacidade de gerar riqueza. A tecnologia foi paulatinamente modificada de tal forma que, se ainda são importantes as instalações industriais, muito mais o são a tecnologia e a informação agregada às mesmas ${ }^{156}$.

Ao longo do século XX, o que se vê é a consolidação da internacionalização tanto das legislações quanto da própria expansão de fronteiras comerciais, tornando o mundo cada vez menor. Marcos importantes dessa nova realidade são o estabelecimento da Liga das Nações, em 1919, e sua substituição pela ONU em 1945. Pensada como um sucedâneo da Liga das Nações, a ONU foi criada com os objetivos principais de salvaguardar a paz mundial, proteger os direitos humanos, fomentar direitos iguais para todos os povos e melhorar os padrões de vida no mundo.

\footnotetext{
${ }^{153}$ Em vigor no Brasil através do Decreto Legislativo no $75.572 / 75$ (Revisão de Estocolmo).

${ }^{154}$ BARBOSA, Cláudio. Op. cit. p. 30.

${ }^{155}$ SILVEIRA, Newton. Licença... Op. cit. p. 16.

${ }^{156}$ BARBOSA, Cláudio. Op. cit. p. 09.
} 
Não menos importante, o GATT ${ }^{157}$ e sua sucessora, a OMC ${ }^{158}$, exercem papel relevante para o desenvolvimento da marca em âmbito internacional. Hoje, um dos principais tratados-contratos administrados pela OMC, o TRIPs ${ }^{159}$, gerencia os aspectos comerciais da Propriedade Intelectual e goza de grande aceitação entre os Estados contratantes.

Continuando sob a interpretação de desenvolvimento internacional, a Propriedade Intelectual foi incluída nas discussões internacionais e através da Convenção de Estocolmo, a ONU, em 1967, cria a OMPI, que, com sede em Genebra, passa a ter como objetivo a proteção da Propriedade Intelecual internacionalmente, de acordo com o artigo $3^{\circ}$ da Convenção de Estocolmo.

Com seu papel definido, a OMPI tenta harmonizar os princípios trazidos inicialmente pela Convenção da União de Paris, de modo a aumentar o entrosamento técnico e jurídico entre as nações, viabilizando a execução de seu objetivo. Ao longo dos seus quase 50 anos, a OMPI conseguiu internacionalizar a Propriedade Intelectual, levando a mensagem de que essa área do conhecimento impulsiona o desenvolvimento dos países e consequentemente, de seus povos.

Sob o ponto de vista prático, a marca, como conhecemos hoje, surgiu com mais veemência a partir do final da Segunda Guerra Mundial. Desde então, com a internacionalização dos mercados, a marca consolidou-se como bem de Propriedade Intelectual dos mais importantes, simbolizando a vitrine do mundo, como o elo de

\footnotetext{
${ }^{157}$ O Acordo Geral sobre Pautas Aduaneiras e Comércio ou Acordo Geral sobre Tarifas e Comércio (em inglês: General Agreement on Tariffs and Trade, GATT) foi estabelecido em 1947, tendo em vista harmonizar as políticas aduaneiras dos Estados signatários. Foi um conjunto de normas e concessões tarifárias, criado com a função de impulsionar a liberalização comercial e combater práticas protecionistas, regular, provisoriamente, as relações comerciais internacionais.

${ }^{158}$ A Organização Mundial do Comércio (OMC) ou em Inglês, World Trade Organization (WTO), é uma organização internacional que trata das relações comerciais entre os 153 Estados membros. É responsável pela discussão e estabelecimento das regras internacionais de comércio.

${ }^{159}$ O Decreto no 1.355/94 internalizou o TRIPs, sigla em Inglês para Acordo sobre Aspectos dos Direitos de Propriedade Intelectual relacionados ao Comércio, tratado internacional negociado no âmbito da Rodada Uruguai de Negociações do GATT, sigla em Inglês para Acordo Geral sobre Pautas Aduaneiras e Comércio ou Acordo Geral sobre Tarifas e Comércio, e que origem à OMC (Organização Mundial do Comércio). O TRIPs gerou obrigações para os Estados-Partes no sentido de adequarem suas legislações referentes à Propriedade Intelectual, oferecendo padrões mínimos de proteção aos bens intangíveis e garantindo harmonização internacional de conceitos técnicos relacionados.
} 
comunicação entre consumidores e produtos. Politicamente, a marca pode ser considerada como o cartão de visita do capitalismo, pois representa a competição entre concorrentes, o poder do consumismo e a necessidade de desenvolvimento dos produtos e da tecnologia.

\section{Definições legislativa e doutrinária}

No dizer de Maitê MORO, os conceitos se caracterizam pela abstração. ${ }^{160} \mathrm{Na}$ ciência jurídica, os conceitos são úteis para a compreensão dos institutos e para determinar a extensão destes. Com esse intuito, devem facilitar uma visão de conjunto e real do objeto conceituado.

Sinal distintivo, portanto, designa qualquer combinação de palavras ou figuras empregadas para identificar um produto ou serviço, empresa ou estabelecimento, de modo a diferenciá-lo dos demais congêneres existentes no mercado. Os sinais distintivos exercem, pois, função individualizante, objetivando atribuir uma identidade própria a seu objeto.

\subsection{Definição legislativa}

O artigo 64 do CPI de 1971 estipulava que "são registráveis como marca os nomes, palavras, denominações, monogramas, emblemas, símbolos, figuras e quaisquer outros sinais distintivos que não apresentem anterioridades ou colidências com registros já existentes e que não estejam compreendidos nas proibições legais”.

O artigo 122 da LPI estabelece que é registrável como marca "os sinais distintivos visualmente perceptíveis e não compreendidos nas proibições legais”.

Percebe-se que o legislador atual não mudou a linha de interpretação sobre o que pode e não pode ser registrado como marca. ${ }^{161}$ Apesar da listagem não exaustiva das

\footnotetext{
${ }^{160}$ MORO, Maitê Cecília Fabbri. Marcas Tridimensionais. São Paulo: Saraiva, 2009. p. 8.

${ }^{161}$ Legislativa e doutrinariamente, houve pouca evolução sobre a definição e natureza jurídica da marca. Desde a Convenção da União de Paris (1883) até o TRIPs (1994), a marca vem sendo definida por qualquer sinal distintivo capaz de distinguir uma origem de outra diversa. Por outro lado, em virtude da evolução da sociedade e de suas relações comerciais, o que vimos é a ampliação do que pode ser considerado sinal distintivo. Além da marca, sinal distintivo clássico, os nomes de domínio na Internet, no início dos anos 90, e ainda os elementos diferenciadores de usuários em redes comunitárias virtuais como Orkut, Facebook e
} 
espécies de sinais a serem registrados, a antiga Lei continuava a estipular os mesmos limites da distintividade, da disponibilidade e das proibições que a lei atual traria. Ausente na lei anterior, o requisito da percepção visual de um sinal distintivo para ser interpretado como marca é encontrado na atual lei, em seu artigo 122, mas não se coaduna com o mundo da sociedade da informação. O TRIPs já condicionava tal requisito aos seus Estados-Membros, de acordo com o já mencionado artigo $15.1 .^{162} \mathrm{O}$ legislador brasileiro deixou de recepcionar as hipóteses de sinais não visuais, mas plenamente capazes de distinguir uma origem da outra.

Um aposto: A lei não trata da possibilidade da marca ser registrável diante do processo de aquisição de distintividade pelo uso. O secondary meaning ${ }^{163}$ não consta expressamente da nossa legislação, mas deveria constar como exceção à regra da distintividade, seguindo a mesma linha do TRIPs, em seu artigo 15.1. Tal ausência tem levado titulares a buscarem o Poder Judiciário ${ }^{164}$ para a proteção cabível a esses sinais considerados intrinsecamente sem distintividade. ${ }^{165}$

As marcas, de acordo com a Diretiva Européia, "[p]odem constituir marcas todos os sinais suscetíveis de representação gráfica, nomeadamente as palavras, incluindo os nomes de pessoas, desenhos, letras, números, a forma do produto ou da respectiva

Twitter, também são considerados signos distintivos e dependendo de sua constituição, capazes de serem protegidos como marcas.

${ }^{162}$ Artigo 15.1. Qualquer sinal, ou combinação de sinais, capaz de distinguir bens e serviços de um empreendimento daqueles de outro empreendimento, poderá constituir uma marca. Estes sinais, em particular palavras, inclusive nomes próprios, letras, numerais, elementos figurativos e combinação de cores, bem como qualquer combinação desses sinais, serão registráveis como marcas. Quando os sinais não forem intrinsecamente capazes de distinguir os bens e serviços pertinentes, os Membros poderão condicionar a possibilidade do registro ao caráter distintivo que tenham adquirido pelo seu uso. Os Membros poderão exigir, como condição para registro, que os sinais sejam visualmente perceptíveis. ${ }^{163}$ SCHMIDT, Lélio Denicoli. Marcas em Semiótica: secondary meaning, vulgarização e teoria da distância. Dissertação de Mestrado em Direito Comercial para PUC-SP, 2010. p. 91: "Secondary meaning é um fenômeno que faz com que um signo comum, originalmente desprovido de distintividade, adquira pelo uso empresarial a capacidade de identificar um produto ou serviço de outro, tornando-se passível de proteção como marca".

${ }^{164}$ Caso Cultura Inglesa: TRF 2 ${ }^{a}$ Região. Apelação Cível 356.235/08 - Rio de Janeiro (2001.51.01.524645-2)

$2^{\mathrm{a}}$ Turma Especializada - Rel. Des. André Fontes. Caso Polvilho Antisséptico: TFR. Apelação Cível 102.635/85 - Rio de Janeiro - (5.796.156) - $5^{\text {a }}$ Turma - Rel. Min. Pedro Acioli. Caso Ultragaz: TFR.

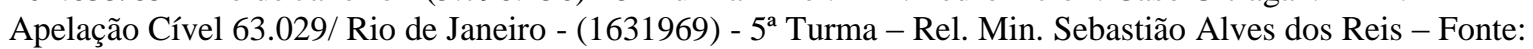
Diário de Justiça, p. 12878, 17 dez. 1981. Caso Kitchens: TRF 2 Região. Apelação Cível 2007.51.01.803363-9. Primeira Turma Especializada. Rel. Juíza Federal Convocada Márcia Helena Nunes. Julgado em 10/09/2009.

${ }^{165} \mathrm{O}$ requisito da distintividade será avaliado com cuidado no presente estudo. 
embalagem, na condição de que tais sinais sejam adequados a distinguir os produtos ou serviços de uma empresa dos de outras empresas". ${ }^{166}$

Já o Lanham Act norte-americano, define marca como "[q]ualquer palavra, nome, símbolo ou dispositivo, ou qualquer combinação destes utilizado por uma pessoa, ou que uma pessoa tem a intenção de boa fé em usá-la no comércio e solicite o registro ao órgão estabelecido pelo presente capítulo, para identificar e distinguir os seus bens, incluindo um produto único, daqueles fabricados ou vendidos por outros e para indicar a origem das mercadorias, mesmo que a origem seja desconhecida". ${ }^{167}$

Vê-se que as legislações estrangeiras não distinguem se a marca deve ou não ser visualmente perceptível para serem consideradas registráveis. As que não são visuais são chamadas de marcas não-tradicionais e são interpretadas pelo consumidor através do olfato, tato, audição, ou pelo conjunto de todos os sentidos. Já não é nova a idéia de que a capacidade distintiva de um sinal não se limita ao que se vê. Como exemplo, conjectura-se a possibilidade de um consumidor identificar o estabelecimento onde está mesmo que com uma venda nos olhos, diante das características não-visuais que o mesmo possui. Melhor exemplo pode ser ilustrado com o tal consumidor, assistindo a um canal de televisão, e ao ouvir o sinal sonoro PLIN-PLIN, imediatamente responde qual canal se trata.

Com isso, o artigo 122 deixou de oferecer proteção positiva ao chamado tradedress, que consiste na reunião de características de um estabelecimento capaz de oferecer informações suficientes ao interpretante sobre a origem dessas informações. Protegido pelo Lanham Act ${ }^{168}$ desde 1946, o instituto do trade dress configura-se na proteção da imagem total e aparência geral de um produto ${ }^{169}$. Ou, como consta com melhor clareza da decisão do 7 th Circuit da Justiça americana ${ }^{170}$, o trade dress constitui-se "na imagem total de um

\footnotetext{
${ }^{166}$ Diretiva $\mathrm{n}^{\circ}$ 2008/95/EC, art. 2. Tradução livre do original: “A trade mark may consist of any signs capable of being represented graphically, particularly words, including personal names, designs, letters, numerals, the shape of goods or of their packaging, provided that such signs are capable of distinguishing the goods or services of one undertaking from those of other undertaking.

${ }^{167}$ Lanham Act $\S 45$ (15 U.S.C. $\left.§ 1127\right)$. Tradução livre do original: "The term "trademark” includes any word, name, symbol, or device, or any combination thereof used by a person, or which a person has a bona fide intention to use in commerce and applies to register on the principal register established by this chapter, to identify and distinguish his or her goods, including a unique product, from those manufactured or sold by others and to indicate the source of the goods, even if that source is unknown".

${ }^{168}$ Lanham Act, Section 43(a) de 1946, 15 U.S.C. $§ 1125$ (a).

${ }^{169}$ Caso Two Pesos, Inc. e Taco Cabana Inc. 112 S.Ct. 2753 (1992).

${ }^{170}$ Caso Kohler Co. vs. Moen Incorporated. 12 F.3d 632 (1993).
} 
produto ou serviço, incluindo aspectos como tamanho, forma, cor ou combinações de cores, texturas, gráficos e até mesmo técnicas particulares de vendas".

O caso brasileiro mais célebre é o da loja de calçados Mr. Cat ${ }^{171}$ já amplamente divulgado e debatido. Veja-se que as marcas não-tradicionais encontram segurança jurídica na legislação comentada, mas sob os domínios da Concorrência Desleal.

Atualmente, visando a aplicação do requisito da percepção visual, o INPI tem permitido a apresentação de marcas nominativas, mistas, figurativas e tridimensionais. Em resumo, as marcas nominativas são representadas por letras e números do alfabeto romano; as mistas são formadas pelo conjunto de elementos nominativos e figuras ou estilização das letras do elemento nominativo; as figurativas são representadas somente por figuras ou letras isoladas com suficiente cunho distintivo; e as marcas tridimensionais, como o próprio substantivo já entrega, são representadas por sua tridimensionalidade, independentemente da presença de elementos nominativos ou figurativos. ${ }^{172}$

O terceiro requisito imposto pelo artigo 122 da LPI alude-se à expressão "não compreendidas nas proibições legais". Tais proibições são encontradas nos 23 (vinte e três) incisos do artigo 124 que tentam consolidar todas as hipóteses de proibições absolutas

\footnotetext{
${ }^{171}$ Poder Judiciário do Estado de Goiás. Quarta Vara Cível de Goiânia. Autos 1101/1997. Ação de indenização. Proferida em 17.set.2001: “As duas grifes decoram suas lojas com os mesmos recursos arquitetônicos onde utilizam madeira na mesma tonalidade de cor nas fachadas, prateleiras, escaninhos e balcões... Outra forte semelhança também está na porta da entrada das lojas, em estilo porta de boutique, por onde passa apenas uma pessoa de cada vez... A loja Mister que estiver mais próxima do consumidor é a loja que virá a vender, porque os produtos são parecidos... a semelhança é indisfarçável... De acordo com o que consta dos pareceres dos especialistas, nas lojas tradicionais os saquinhos que protegem os calçados ficam dentro das caixas dos sapatos, enquanto que nas lojas em questão estes saquinhos ficam a vista dos clientes, em expostos em colméias, provocando uma caracterização exclusiva dessas lojas. Segundo o que consta dos pareceres dos especialistas, os estabelecimentos se confundem pela característica da decoração feita com mobiliário em madeira, saquinhos em algodão ou malha, com logotipo impresso e expostas no interior das lojas, prateleiras em arquibancadas, balcões abertos, caixas recuados ao fundo das lojas e as portas de acesso em estilo boutique, com passagem individual para clientes. Ante aos pareceres dos publicitários que estão sendo juntados aos autos, e a tudo que vimos e analisamos, não restam dúvidas de que, mesmo de maneira sutil em algum ponto, houve a indisfarçável intenção de assemelhar-se”.

${ }^{172}$ Existem inúmeras nuances que permeiam as apresentações visuais das marcas, como por exemplo a regra instituída pelo INPI de que os elementos nominativos tidos como especiais, como @, \&, ®, quando colocados de forma a denotar função das letras a, e e r, respectivamente, serão considerados elementos nominativos. Do contrário, se revestidos de suficiente forma distintiva, serão considerados elementos figurativos. Apesar da lógica, não cogita-se exaurir tais nuances sobre esse tema, mas tão somente analisá-lo como fator influenciador da integridade das marcas, de acordo com o uso das mesmas por seus titulares ou terceiros.
} 
- contrárias à ordem pública e quando as marcas são nulas em si mesmas - e relativas contrárias a direitos privativos de terceiros. ${ }^{173}$

\subsection{Definição doutrinária}

Ao possibilitar a identificação de produtos, serviços ou estabelecimentos dentro do mercado, o signo distintivo, concomitantemente, possibilita a distinção entre concorrentes e o reconhecimento destes pelo público consumidor. ${ }^{174}$ Nesse sentido, CHAVANNE e BURST expressaram que as marcas consistem em "[m]eios fonéticos ou visuais que permitem aos clientes a reconhecer produtos, serviços ou estabelecimentos que se destinam e para distingui-los dos produtos, serviços ou estabelecimentos similares". ${ }^{175}$ Continuam os autores ensinando que "[o] sinal é um signo sensível aposto em um produto ou acompanhando um produto ou serviço e destinado a distinguir os produtos semelhantes de concorrentes ou de serviços prestados para outros". ${ }^{176}$

Em relação às marcas, a imaterialidade as torna suscetíveis de reprodução ilimitada e simultânea. FERNANDEZ-NOVOA, destacando justamente essas características, aduz que a marca é " $[u] m$ bem que não possui existência sensível, mas, pelo contrário, exige materializar em coisas tangíveis (corpus mechanicum) para serem percebidas pelos sentidos, sendo também suscetíveis de serem reproduzidas, simultaneamente, e ilimitadamente em vários mercados". 177

\footnotetext{
${ }^{173}$ Da mesma forma que a apresentação visual das marcas, as proibições listadas pelo artigo 124 da LPI só serão analisadas no presente estudo se forem relevantes para o estudo da variação da integridade das marcas mediante o seu uso pelos titulares ou terceiros.

${ }^{174}$ Interessante notar que o Dicionário De Plácido e Silva define marca sob o mesmo prisma, pois "serve de terminologia jurídica para indicar o sentido, a significação, a interpretação, que se tem a respeito das coisas, dos fatos, das palavras. Cf. SILVA, De Plácido e. Vocabulário Jurídico. 12 $2^{\text {a }}$ Ed. Rio de Janeiro: Forense, 1993. v. 1, p. 484.

${ }^{175}$ CHAVANNE, Albert e BURST Jean-Jacques. Droit de La propriété industrielle. $5^{\mathrm{a}}$ ed. Paris: Dalloz, 1998, p. 471. Tradução livre de: "ce sont les moyens phonétiques ou visuels qui permettent à la clientèle de reconnaître les produits, les services ou les établissements qu'elle recherche et de les distinguer dês produits, des services ou des établissements similaires". No mesmo sentido, GUSMÃO, José Roberto. Painel Mudanças introduzidas pelo INPI na análise dos pedidos de registro de marcas e no processamento delas. In: XIV Seminário Nacional da Propriedade Intelectual. Anais 1994. ABPI: Rio de Janeiro, 2003: “a marca é o elemento da reunião da clientela de seu titular, e é a ele destinada a primeira e principal proteção jurídica".

${ }^{176}$ CHAVANNE e BURST. Op. cit. p. 479: Tradução livre de "la marquee est un signe sensible appose sur un produit ou accompagnant un produit ou service et destiné à le distinguer des produits similaires des concurrents ou des services rendus par d'autres".

${ }^{177}$ FERNANDEZ-NOVOA, Carlos. Fundamentos del derecho de marcas, Madri: Montecorvo, 1984, p.

21. Tradução livre de: “[u]m bien qe no tiene existência sensible, sino que, por el contrario, necesita
} 
Por sua vez, MAILLARD DE MARAFY se aproxima da distintividade, elemento importante para que um signo seja considerado marca. Diz o autor que "[s] ão considerados como marcas registradas ou comerciais: os nomes em uma forma distinta, as denominações, se elas não forem necessárias, etiquetas, envelopes, formas características, carimbos, selos, ourelas, bordas, combinações de cores, desenhos, relevos, letras, números, moedas, pseudônimos, nomes fantasiosos, assinaturas, e em geral, todos os recursos materiais utilizados para distinguir os produtos de uma fábrica, uma fazenda, floresta ou extrativa e objetos de um comércio". ${ }^{178}$

POULLIET, por sua vez, prefere se aproximar da função distintiva da marca, ao defini-la como "[t]odos os sinais de qualquer tipo, usados para distinguir a individualidade de uma mercadoria produzida por um fabricante, ou simplesmente vendida por comerciante". ${ }^{179}$

A doutrina nacional vem, há muito, expressando seus comentários acerca da definição da marca. GAMA CERQUEIRA define-a como "[t]odo sinal distintivo aposto facultativamente aos produtos e artigos das indústrias em geral para identificá-los e diferenciá-los de outros idênticos ou semelhantes de origem diversa". ${ }^{180}$ Curioso notar que a noção de marca oferecida por GAMA CERQUEIRA espelhava a preocupação encontrada na Convenção da União Paris de $1883^{181}$ quanto ao caráter distintivo da marca.

materializarse em cosas tangibles (corpus mechanicum) para ser percebido por los sentidos, siendo, además suceptible de ser reproducido ilimitadamente y de modo simultáneo em diversos mercados".

${ }^{178}$ MAILLARD DE MARAFY, Le Cte d. Grand dictionnaire international de la propriété industrielle au point de vue du nom commercial des marques de fabrique et de commerce et de la concurrence déloyale. Paris: Chevalier-Marescq et Cie, 1891. v. 4 e 5. Tradução livre do original:"sont consideres comme constituant des marques de fabrique ou de commerce: les noms sous une forme distinctive, les dénominations, si elles ne sont pás nécessaires, étiquettes, enveloppes, formes caractéristiques, timbres, cachets, vignettes, lisières, liserés, combinaisons des coulers, dessins, reliefs, lettres, chiffres, devises, pseudonymes, noms imaginaires, signatures, et em general, tous moyens matériels servant à distinguer les produits dúne fabrique, d'une exploitation agricole, forestière ou extrative, et les objets d'um commerce".

${ }^{179}$ POUILLET, Eugène. Traité des marques de fabrique et de la concurrence déloyale em tous genres. Paris: Marchal et Billard, 1898, p. 14. Tradução livre de: “toute signe, quel qu'il soit, servant à distinguer l'individualité d'une marchandise, soit manufacturée par um fabricant, soit simplement vendue par um commerçant".

${ }^{180}$ CERQUEIRA, João da Gama: Tratado da Propriedade Industrial. $4^{\mathrm{a}}$ Ed. revista e atualizada por Newton Silveira e Denis Borges Barbosa. Vol. I, p. 253. Rio de Janeiro: Lumen Juris, 2010.

${ }^{181}$ Artigos $5^{\circ} \mathrm{C}, 6^{\circ}$ ter, $6^{\circ}$ quinquies B e $6^{\circ}$ quinquies $\mathrm{C}$ da Convenção da União de Paris de 1883 , revisão de Estocolmo (1967) internalizada pelo Decreto $\mathrm{n}^{\circ} 75.572$, de 08 de abril de 1975. 
Além disso, ele também dava ciência da conotação industrial e comercial de aposição da marca em um produto de modo a distinguir as mercadorias. ${ }^{182}$

PONTES DE MIRANDA ${ }^{183}$ preferiu tecer comentário introdutório aos sinais distintivos objetivando demonstrar que estes são gênero e que marca é sua espécie. Mais adiante, ele demonstra sua preocupação em anotar que a "[m]arca tem de distinguir. Se não distingue, não é sinal distintivo, não assinala o produto (Decreto-Lei $n^{\circ} 7.903$, art. 89, parágrafo único), não se lhe podem mencionar 'elementos característicos' (art. 126, IV)".

Newton SILVEIRA ${ }^{184}$ afirma que marca é “[t]odo nome ou sinal hábil para ser aposto a uma mercadoria ou produto ou indicar determinada prestação de serviços $e$ estabelecer entre consumidor ou usuário e a mercadoria, produto ou serviço uma identificação, constitui marca". Vê-se que a doutrina mais recente continuou a exigir distintividade das marcas quando sutilmente colocou que o sinal tem que ser hábil para ser aposto a uma mercadoria. A habilidade, nesse entendimento particular, tem de ver com a distintividade objeto do inciso VI do artigo 124 da LPI e com a disponibilidade tratada pelo inciso XIX do mesmo artigo 124 da mesma lei.

Continua o autor comentando sobre a necessária suficiência distintiva dos signos que não podem ser registrados como marca "o nome próprio do produto ou outros nomes ou sinais que genérica e usualmente são empregados em relação ao produto sem com isso implicar em distinção entre uns e outros da mesma espécie e gênero". ${ }^{185}$

Denis Borges BARBOSA registra que "[a] marca serve, tradicionalmente, para assinalar a sua origem e, em face de outras marcas para itens competitivos, indicar a diferença. Mas, usada como propaganda, além de poder também identificar a origem e as diferenças relativas em face de competidores, deve primordialmente incitar ao consumo ou valorizar a atividade empresarial do titular". ${ }^{186}$ Apesar da visão científica de formação das

\footnotetext{
${ }^{182}$ CERQUEIRA. Op. cit... p. 253.

${ }^{183}$ MIRANDA, Pontes de: Tratado de Direito Privado. $4^{\text {a }}$ Ed. Tomo XVII, págs. 3-6. São Paulo: Revista dos Tribunais, 1977.

${ }^{184}$ SILVEIRA, Newton. Curso... Op. cit. p. 19.

${ }^{185}$ SILVEIRA, Newton. Curso... Op. cit. p. 20.

${ }^{186}$ BARBOSA, Denis. Proteção das Marcas... Op. cit. p. 5. No mesmo sentido, SCHECHTER: Marca é “o agente mais eficiente de boa-fé, imprimindo sobre a opinião pública uma garantia anônima e impessoal de satisfação, criando o desejo por mais satisfações”. Tradução livre do original: “(...) [t]he most effective
} 
marcas e ainda econômica por sua função, o autor não deixou de comentar sobre a necessidade de uma marca ter de distinguir sua origem de outrem e de ser capaz de distinguir o produto ou serviço assinalado pela mesma. ${ }^{187}$

Lélio SCHMIDT estabelece que sinais distintivos que designam qualquer combinação de palavras ou figuras empregadas para identificar um produto ou serviço, empresa ou estabelecimento, de modo a diferenciá-lo dos demais congêneres existentes no mercado podem ser considerados marcas, as quais exercem função individualizante, objetivando atribuir uma identidade própria a seu objeto. ${ }^{188}$

Sob o ponto de vista informacional, Cláudio BARBOSA ${ }^{189}$ leciona que a marca consiste em um feixe de informações capaz de distinguir uma fonte da outra. Muito mais do que simplesmente apontar um comerciante específico, a marca organiza a sinergia entre o emissor dessas informações, tradicionalmente chamado de titular, e o receptor, chamado de público.

Sob o ponto de vista da disponibilidade, à coisa sem dono (res nullius ${ }^{190}$ ), resta esperar por um interessado que requererá sua exclusividade para si, através de procedimento administrativo organizado pelo Poder Público ${ }^{191}$, tornando-a sua (res alii $^{192}$ ),

agent of goodwill, imprinting upon the public mind an anonymous and impersonal guaranty of satisfaction, creating a desire for further satisfactions". SCHECHTER. Op. cit. p. 819.

${ }^{187}$ BARBOSA, Denis. Proteção das Marcas... Op. cit. p. 69: “Assim, uma marca não será registrada (tornando-se, assim, exclusiva) se não for distintiva em suas duas modalidades, ou seja, capaz de distinguir o produto assinalado dentre todos os concorrentes e, ao mesmo tempo, fixando-se na percepção do público de forma a apontar o produto em questão"

${ }^{188}$ SCHMIDT, Lélio Denícoli. Princípios Aplicáveis aos Sinais Distintivos. In: SANTOS, Manoel J. Pereira dos e JABUR, Wilson Pinheiro (Orgs.). Sinais Distintivos e Tutela Judicial e Administrativa. Série GVLaw. São Paulo: Saraiva, 2007. p. 31.

${ }^{189}$ Para uma ampla análise sobre a Propriedade Intelectual como informação, ver BARBOSA, Cláudio Roberto. Introdução à propriedade intelectual como informação. São Paulo: Campus Jurídico, 2007.

${ }^{190}$ DE PLÁCIDO E SILVA. Vocabulário jurídico. Rio de Janeiro: Forense, 2004: “Abarca lato sensu, tanto as coisas extra commercium (fora de comércio) quanto as res derelictae (coisas abandonadas). É importante destacar que há res nullius inapropriável por ser res publicae e apropriável, enquanto coisa sem dono".

${ }^{191} \mathrm{O}$ sistema adotado pelo Brasil para o alcance do direito de uso exclusivo de marca no Brasil é o atributivo de direito. Ou seja, o Poder Público atribuiu a uma autarquia (INPI) o poder de conceder tais direitos a entes privados mediante um procedimento administrativo obrigatório (art. 129 LPI).

${ }^{192}$ BARBOSA, Denis. Proteção das marcas... Op. cit. p. 326: "A marca de terceiros, que vedará um novo registro ou causará o conflito no caso de uso, é a protegida pelo direito exclusivo, isto é, a marca registrada; no costumo administrativo do INPI, tal registro diz-se uma anterioridade". 
e evitará que a mesma reverta ao domínio público (res communis omnium ${ }^{193}$ ), ou a outrem, retornando a mesma ao status de res nullius. ${ }^{194}$

\section{Funções de uma marca}

\subsection{Considerações gerais}

Lélio SCHMIDT, citando HILTON, afirma que o capitalismo não pode funcionar sem uma sociedade de consumo e é impossível uma sociedade de consumo sem marcas ${ }^{195}$. As marcas permitem a existência da concorrência, viabilizando a competição entre os anunciantes pela atenção dos consumidores. Sem dúvida que a marca exerce papel fundamental na sociedade capitalista pois representa o direito de escolha do consumidor, o sinal de sua individualização perante o mercado e ainda, o veículo que economiza tempo e despesas para a sua escolha.

Sob esse prisma, a marca pode ser interpretada como um redutor dos custos de transação, pois permite ao interpretante (consumidor) avaliar, antes de sair de casa, as características do produto escolhido, a história do fabricante e do vendedor, de modo a evitar que, como antigamente, os consumidores vaguem entre os estabelecimentos comerciais atrás do menor preço. Atualmente, as ferramentas de pesquisa são mais ágeis, permitindo uma reunião de informações sem grande esforço do consumidor.

Segundo Nicholas ECONOMIDES, “[A]s razões primárias para a existência e proteção das marcas são que 1) elas facilitam e estimulam as decisões dos consumidores e 2) criam incentivos para as empresas produzirem produtos de qualidades desejáveis mesmo quando estas não sejam observáveis antes da compra”. 196

\footnotetext{
${ }^{193}$ A res communis omnium é a coisa comum a todos, impassível de apropriação exclusiva por quem quer que seja. $\mathrm{O}$ fenômeno da degenerescência de marca significa a perda de uma marca plenamente distintiva para o domínio público, tendo em vista a transformação de seu caráter distintivo em de uso comum.

${ }^{194}$ A extinção do registro de marca por falta de uso e o disponibilização da mesma como res nullius: processo de caducidade de acordo com o artigos 142 e seguintes da Lei no 9.279/96.

${ }^{195}$ SCHMIDT. Marcas em semiótica... Op. cit. . p. 17.

${ }^{196}$ ECONOMIDES, Nicholas S. The economics of trademarks. In: The Trademark Reporter v. 78, Nova Iorque: INTA, 1988. p.p. 523-539. Em sentido parecido, COASE, Ronald H: The problem of social costs. In: Journal of Law and Economics, 3, $\mathrm{n}^{\circ}$ 1:1-44, 1960: “O argumento procedeu-se a este ponto no pressuposto de que não há custos envolvidos na realização de operações de mercado. Isto é, evidentemente, uma hipótese não muito realista. A fim de levar a cabo uma operação de mercado é necessário para descobrir quem éo que se deseja tratar, para informar as pessoas do que se deseja tratar e em que termos, para conduzir as
} 
Todavia, mais do que um elemento econômico do mercado, a marca representa o direito de propriedade e o direito de uso exclusivo em todo território nacional, como nota SCHMIDT $^{197}$. Então, apesar do foco econômico, não há como dissociar o objetivo jurídico que a marca exerce, ou seja, a de estabelecer limites de direitos entre os concorrentes a fim de se evitar prejuízos do titular da marca e dos consumidores. $\mathrm{Na}$ verdade, a função jurídica da marca será aquela que esteja protegida pelo ordenamento jurídico de cada Estado. ${ }^{198}$

A função da marca, como instituto jurídico, é a realização do ato de distinguir, com vistas a diferenciar produtos e serviços de outros idênticos, semelhantes ou afins, de origem diversa. ${ }^{199}$ Complementando, Denis BARBOSA entende que a marca também deve garantir ao consumidor a capacidade de discernir o bom e o mau produto. $\mathrm{O}$ exercício equilibrado e compatível com a função social dessa propriedade levaria a que o investimento em qualidade fosse reconhecido. ${ }^{200}$

Contudo, a marca não garante qualidade, mas somente uma reunião de informações capaz de informar ao consumidor e ao mercado sobre suas características que podem ou não fazer repetir o consumo. De acordo com SAINT-GAL, "[s]e a marca pode constituir uma presunção de qualidade sob o ponto de vista econômico, ela não oferece garantia de qualidade sob o ponto de vista jurídico, exceto certas formas de marcas coletivas ou de certificação". ${ }^{201}$

negociações que levaram a um negócio, para redigir o contrato, para realizar a inspeção necessária para garantir que os termos do contrato estão sendo observados, e assim por diante. Essas operações são muitas vezes extremamente caras, tão caras de qualquer forma que evitam que muitas operações sejam realizadas em um mundo em que o sistema de preços funcionou sem custo".

${ }^{197}$ SCHMIDT. Marcas em semiótica... Op. cit. p. 18.

${ }^{198}$ MORO. Op. cit. p. 62.

${ }^{199}$ MORO. Op. cit. p. 62.

${ }^{200}$ BARBOSA, Denis. Proteção das marcas... Op. cit. p. 13.

${ }^{201}$ SAINT-GAL, Yves. Protection et défense des marques de fabrique et concurrence déloyale: droit français et droits étrangers. $5^{\mathrm{a}}$ Ed. Paris: J. Delmas et Cie., 1982. p. A-11 e A-12. Tradução do original: "[s]i la marque peut constituer une présomption de qualité sur le plan économique, elle n'offre pás de garantie de qualité sur le plan juridique, sauf certaines formes de marques collectives ou de certification". No mesmo sentido, ASCENSÃO, José de Oliveira. As funções das marcas e os descritores meta-tags. In RABPI v. 61, nov./dez. 2002, p. 17. "A marca não dá nenhuma garantia jurídica de qualidade. A qualidade do produto ou serviço pode aumentar ou diminuir sem que isso tenha reflexos jurídicos; só terá reflexos mercadológicos. Não há pois também uma função de garantia. (...) Assim, se alguém adquirir marca de renome e fizer o cálculo de a aplicar a produtos ruins, escoando-os rapidamente graças ao apelo da marca e amortizando o investimento feito, não violou nenhum preceito jurídico". E SILVEIRA, Newton. Licença... 


\subsection{Função de determinação da origem}

$\mathrm{Na}$ Antiguidade, tem-se o início do uso de marcas pelas próprias pessoas. A função da marca nessa época era restrita à indicação da propriedade do objeto. ${ }^{202}$ Além dessa função, GAMA CERQUEIRA ressalta a utilização de marcas nesse período como denotação de autoria. Entretanto, alguns autores admitem o uso excepcional na Idade Antiga de signos postos sobre produtos, que tinham por finalidade garantir a origem ou a qualidade do produto. ${ }^{203}$

SCHECHTER também ensina no mesmo sentido quanto à função da marca em identificar um produtor quando escreve que “(...) [a] marca proprietária que era opcional, mas geralmente aposta em produtos pelo proprietário, ou para o benefício de funcionários analfabetos ou de forma que em caso de naufrágio ou pirataria, os produtos poderiam ser identificados e recuperados pelo proprietário". 204

Na Idade Média, as marcas passaram a ser utilizadas pelas corporações de ofício em um contexto comercial, quando foram reconhecidas no âmbito jurídico. Nesse momento, verificou-se, ainda, uma modificação do uso e, portanto, da função da marca, que, de sinal de indicação de autoria ou propriedade de um objeto, passou a indicar uma origem comercial, a corporação de ofício da qual provinha o produto. ${ }^{205}$

Em resumo, a função de indicação de origem das marcas está esvaziada pelas práticas empresariais globalizadas. Diferentemente da Antiguidade e da Idade Média, a função de distinguir a origem através das marcas já não serve como parâmetro de distinção.

Op. cit... p. 16: A marca não garante qualidade “(...) senão na medida em que o empresário deseje manter o padrão de qualidade de seus produtos por ela assinalados, a fim de que não caiam em descrédito".

${ }^{202}$ No mesmo sentido, SCHECHTER. Op. cit. p. 814: “A origem ou propriedade assim designados por uma marca deve ser a origem pessoal ou de propriedade”. Tradução livre do original: "The origin or ownership so designated by a trademark must be the personal origin or ownership".

${ }^{203}$ MORO. Op. cit. p. 63.

${ }^{204}$ SCHECHTER. Op. cit. p. 814. Tradução livre do original: “(...) the proprietary mark, which was optionally but usually affixed to goods by the owner, either for the benefit of illiterate clerks or in order that in case of shipwreck or piracy the goods might be identified and reclaimed by the owner".

${ }^{205}$ MORO. Op. cit. pp. 63/64. 
Após a Revolução Francesa, o movimento de proteção às criações intelectuais nasceu e com ele, a necessidade de se proteger a função de determinação de origem dos produtos para evitar que os mais afoitos se servissem do conceito dos produtos alheios. ${ }^{206}$

A marca constitui verdadeiro símbolo de identificação de um determinado agente econômico frente aos seus concorrentes e consumidores. ${ }^{207}$ De acordo com Newton SILVEIRA ${ }^{208}$, “[A] proteção aos sinais distintivos utilizados pelo empresário no exercício da empresa decorre de seu direito a individualizar-se em uma situação de concorrência".

Nesse sentido é que o autor entende que não se pode mais falar em indicação de origem executada pela marca já que a mesma "[é] sinal de origem no sentido de que o proprietário do sinal é o responsável pela fabricação do produto (quando se tratar de marca de indústria), determinando quem e como o fará”. E continua seu entendimento comentando que " $[\mathrm{O}]$ crédito ou descrédito resultantes incidirão sobre o proprietário da marca, inferindo de forma positiva ou negativa sobre o aviamento do estabelecimento". ${ }^{209}$

José de Oliveira ASCENSÃO igualmente opõe-se à função de indicação de origem da marca, asseverando que o entendimento de que os produtos apostos com uma marca asseguram a mesma origem de fabricação é insustentável. Cita, inclusive, sobre a possibilidade de um negócio ser transferido independentemente das marcas que o compõem, o que deixa de servir como indicação de origem dos produtos apostos pela marca transferida ou não. ${ }^{210}$ Adicionalmente, o autor coloca a possibilidade de uma marca servir de objeto para contratos de licença de uso a terceiros, levantando a hipótese de que bons e maus produtos circulam com a mesma marca.

\footnotetext{
${ }^{206}$ SILVEIRA, Newton. Curso... Op. cit. p. 14.

${ }^{207}$ Nesse sentido, SCHECHTER estende a percepção individualizadora da marca para a noção econômica da mesma ao escrever que " $[A]$ s verdadeiras funções da marca são, então, identificar um produto como satisfatório e assim estimular futuras compras pelo público consumidor". Tradução livre do original: "The true functions of the trademark are, then, to identify a product as satisfactory and thereby to stimulate further purchases by the consuming public". SCHECTHER. Op. cit. p. 818.

${ }^{208}$ SILVEIRA, Newton. Licença... Op. cit. p. 15.

${ }^{209}$ SILVEIRA, Newton. A propriedade intelectual e as novas leis autorais. $2^{a}$ ed. rev. ampl. São Paulo: Saraiva, 1996. p. 24-25. O mesmo autor expressa a opinião em outra de suas obras: SILVEIRA, Newton. Licença. Op. cit. p. 2: "o consumidor ignora quem seja o fabricante do produto assinalado pela marca". No mesmo sentido, OTAMENDI, Jorge. Derecho de marcas. $5^{\text {a }}$ ed. Buenos Aires: Abeledo-Perrot, 2003. p. 8. $\mathrm{O}$ autor considera a função de indicação de origem ultrapassada e que a grande maioria do público ignora quem é o fabricante dos produtos que adquire, definindo tal função como secundária.

${ }^{210}$ ASCENSÃO, José de Oliveira. As funções da marca e os descritores (metatags) na internet. In: RABPI. v. 61. pp. 44-52. Rio de Janeiro: ABPI, 2002.
} 
De certa forma, ASCENSÃO concorda com SCHECHTER, pois este também critica a função de identificação de origem da marca. SCHECHTER entende que mais do que identificar uma origem a marca “(...) [i]ndica, não que o produto em questão provê de uma fonte determinada ou particular, as características ligadas que são especificamente conhecidas pelo consumidor, mas apenas que os produtos em questão emanam da mesma - possivelmente anônima - fonte ou chegam aos consumidores através dos mesmos canais como outras mercadorias que já deram satisfação ao consumidor, e que tinham a mesma marca". 211

Na visão econômica de Denis BARBOSA, a origem a que se refere o direito de marcas é simplesmente o valor concorrencial resultante da coesão e consistência dos produtos e serviços vinculados à marca, que, na perspectiva do consumidor, minoram seu custo de busca de alternativas, e, da perspectiva do investidor, representam a expectativa razoável de uma clientela. Esta relação fática e bilateral, que se realimenta, transcende as licenças, prescinde da garantia de qualidade, ignora a geografia e as peculiaridades de um estabelecimento fabril. $^{212}$

\subsection{Função distintiva}

A função distintiva de uma marca, para ASCARELLI, é a principal: "[a] sua função é necessária e suficiente, no entanto, para uma identificação objetiva do produto". 213

Na visão de CHAVANNE e BURST, “[a] marca deve identificar o produto ou serviço entre os produtos ou serviços do mesmo tipo oferecidos pelos concorrentes. É, portanto, necessário que uma marca apresente uma característica distintiva". ${ }^{214}$

\footnotetext{
${ }^{211}$ SCHECHTER. Op. cit. p. 816. Tradução livre do original: "It indicates, not that the article in question comes from a definite or particular source, the characteristics of which or the personalities connected with which are specifically known to the consumer, but merely that the goods in connection with which it is used emanate from the same - possibly anonymous - source or have reached the consumer through the same channels as certain other goods that have already given the consumer satisfaction, and that bore the same trademark".

${ }^{212}$ BARBOSA, Denis. Proteção das marcas... Op. cit. p. 24. No mesmo sentido, ASCENSÃO. As funções da marca... Op. cit.

${ }^{213}$ ASCARELLI, Tullio. Teoria... Op. cit. p. 301. Tradução livre de: "[l]a sua funzione necessária e sufficiente è comunque quella di uma identificazione obbiettiva del prodotto".
} 
Na mesma linha, Mario ROTONDI também expressa que a marca serve para distinguir produtos na concorrência, anotando que "[m] arca gráfica impressa ou aplicada aos produtos, a fim de distinguir-se de todos os outros produtos similares disponíveis no mercado e de outras empresas". ${ }^{215}$

Paul ROUBIER traz uma noção um pouco mais comercial quanto à função distintiva da marca ao comentar que a mesma serve para "contribuir para a conservação de clientes: liga-se alguns sinais que servem como foco de concentração e permite que eles reconheçam o produto ou estabelecimento". 216

BEEBE frisa que a função distintiva integra a própria definição do que é marca, pois esta é um signo que identifica um produto ou serviço no mercado. ${ }^{217}$

O titular de marcas enfrenta um processo contraditório, aos olhos de Cláudio BARBOSA, pois há necessidade de ampliar a informação vinculada aos sinais distintivos exponencialmente, mas não deve ser feita de forma meramente quantitativa, deve ser feita com critério a fim de ampliar e manter a função de identificação do sinal distintivo. ${ }^{218}$

$\mathrm{O}$ autor continua comentando que, a partir do momento em que os sinais distintivos ampliam sua função, demandam novas formas de proteção que não se encaixam mais no contexto previamente existente. As regras contrárias à diluição (causada por terceiros) demonstram o expansionismo dos sinais distintivos, que podem ser sentidos

\footnotetext{
${ }^{214}$ CHAVANNE e BURST. Op. cit. p. 548. Tradução livre de: "[l] a marque doit permettre d'identifier um produit ou um service parmi les produits ou les services de même nature proposés par les concurrents. Il est donc nécessarire que la marque presente um caractere distinctif".

${ }^{215}$ ROTONDI, Mario. Diritto Industriale. Pádua: Cedam, 1965. p. 107. Tradução livre do original: "[c]ontrassegno gráfico impresso od applicato ai prodotti, al fine di distringuerli da tutti gli altri prodotti simili esistenti in commercio e provenienti da altre aziende".

${ }^{216}$ ROUBIER, Paul. Le Droit de La Propriété Industrielle. Paris: Sirey, 1952. p. 461. Tradução livre do original: "[a]préciés concourent à la conservation de la clientèle: celle-ci se fixe sur certains signes qui lui servent de ralliement, et lui permettent de reconnaeître les produits ou les établissement, qu'elle apréciés". Continua o autor comentando que a marca também serve como "[m]eios materiais para garantir oo comprador de um produto que o mesmo venha realmente de um fabricante, a marca abrange produtos que circulam e com ele, o público vai encontrar o artigo que ele prefere, de acordo com a marca, que apresenta". Tradução livre do original: "[m] oyen matériel de garantir à l'acheteur d'um produit qu'il provient bien de tel fabricant; la marque couvre le produti et ciculer avec lui; le public retrouvera l'article qu'il prefere, d'après la marque qu'on lui presente". ROUBIER. Op. cit. p. 18.

${ }^{217}$ BEEBE, Barton: The semiotic analysis of Trademark Law, in UCLA Law Review, v. 51, 2004, p. 645.

${ }^{218}$ BARBOSA, Cláudio, Op. cit. p. 161.
} 
igualmente na pressão pela ampliação das indicações geográficas e outras denominações vinculadas à origem. ${ }^{219}$

De acordo com Newton SILVEIRA, a finalidade da marca é identificar o produto, ou seja, é necessário que a marca tenha características que permitam tal identificação. $\mathrm{O}$ autor resume que "[a] marca é um sinal, que se acresce ao produto para identificá-lo e que deve ser suficientemente característico para preencher tal finalidade".220

Para Denis BARBOSA, uma marca deve diferenciar-se das marcas que disputam o mesmo mercado de forma tal que lhe garanta a unicidade: o reconhecimento de que a origem indicada por uma marca se distingue da origem de outra. ${ }^{221}$

Maitê MORO é firme ao afirmar que as funções distintiva e de indicação de origem não são incompatíveis. Na visão da autora, elas estão ligadas já que a função distintiva contém a de indicação de origem. ${ }^{222}$ E prossegue afirmando que um dos enfoques possíveis para a marca no exercício da função distintiva é o da possibilidade de identificação do produto ou serviço assinalado, indicando que o aspecto da identificação pura é o ponto de crítica daqueles que entendem que a função primordial é o da indicação de origem. E por fim, decreta que não mais procede o raciocínio da marca como indicadora necessária de uma origem determinada. ${ }^{223}$

\subsection{Função econômica}

Desde a Idade Antiga, como se viu anteriormente, a marca vem evoluindo ${ }^{224} \mathrm{de}$ acordo com os avanços da sociedade, da tecnologia e dos conhecimentos dos indivíduos.

\footnotetext{
${ }^{219}$ BARBOSA, Cláudio, Op. cit. p. 161

${ }^{220}$ SILVEIRA, Newton. Curso... Op. cit. p. 19 e 65. No mesmo sentido BITTAR e BITTAR FILHO. Op. cit. p. 193: "[a] marca e seus elementos desempenham funções distintivas da empresa e de seus produtos, possibilitando aos consumidores o exercício de sua liberdade de escolha, dentro de um regime de pluralidade de oferta".

${ }^{221}$ BARBOSA, Denis. Proteção das marcas... Op. cit. p. 85.

${ }^{222}$ MORO. Op. cit. p. 89.

${ }^{223}$ MORO. Op. cit. p. 94.

${ }^{224}$ SILVEIRA. Curso... Op. cit. p. 16: “A marca evoluiu da 'assinatura' do produtor aposta ao produto, ou de um sinal de propriedade aposto às mercadorias em trânsito ou depositadas em armazéns, a um sinal que
} 
Tal evolução propugna a concepção da marca como elemento da concorrência, possibilitando o crescimento de novas origens, aumentando a competição, favorecendo ao consumidor, por seu inafastável poder de escolha.

Nesse sentido, a marca vem exercendo cada vez mais o papel de bem econômico na medida em que ela simboliza a oferta de produtos e serviços à população. Sob o ponto de vista da Economia, a marca, enquanto bem privado, demanda por esforços de seus titulares que objetivam desenvolver seus negócios. Caso não houvesse a outorga de direitos sobre o uso exclusivo desses sinais, pouco interesse surgiria na Propriedade Intelectual. Acaso inexistisse o trade-off entre os interesses público e privado na Propriedade Intelectual, dificilmente ter-se-ia agentes econômicos motivados a despender investimentos nessa área da Ciência.

Dessa forma, importante tecer alguns comentários sobre a economicidade dos sinais distintivos. O bem público (res publica) tem uma dupla acepção jurídica na visão de Cláudio BARBOSA: pode tanto designar bens de uso comum do povo, como bens pertencentes às pessoas jurídicas de direito público interno. ${ }^{225}$ Já para a Economia, bem público é o bem não-rival e não-excludente, ou seja, seu uso não rivaliza com terceiros, permitindo que o mesmo seja simultâneo por quantos indivíduos possíveis, e o uso por um indivíduo não impossibilita o uso por terceiros posto que a coisa permanece à disposição do indivíduo com sua integridade inabalada. ${ }^{226}$

Dessa forma, bens públicos acarretam um problema específico que é a falta de motivação para produzí-los, pois não é eficiente despender tempo e esforço para a produção de um bem não-rival e não-excludente.

Do outro lado, o bem privado, de acordo com a Economia, é aquele que gera rivalidade e excludência. Por rivalidade, entende-se que o consumo de um bem por uma

vai atuar diante dos consumidores para identificar uma procedência constante de determinado produto, mercadoria ou serviço, oferecidos em concorrência com outros de procedência diversa".

${ }^{225}$ BARBOSA, Cláudio, Op. cit. p. 11.

${ }^{226}$ No mesmo sentido, BARBOSA, Cláudio, Op. cit. p. 11. 
pessoa deixa menos do mesmo bem para o consumo de outra pessoa. ${ }^{227}$ E por excludência, entende-se que o consumo de um bem por uma pessoa exclui outra de consumir, ao mesmo tempo, o mesmo bem. ${ }^{228}$

Além de resultar em segurança aos criadores, que se sentem incentivados a alocar seus recursos para a obtenção de direito de uso exclusivo, a propriedade sobre os bens de Propriedade Intelectual também é capaz de gerar a diminuição de assimetrias de informação, pois presumindo-se a aplicação do princípio da veracidade - as marcas não podem ser deceptivas ${ }^{229}$ - a origem dos produtos e serviços assinalados por uma marca contribuirá para a tomada de informações necessárias para que o consumidor faça sua escolha. Sob esse ponto de vista, a existência de delimitações entre as diversas origens diminui o tempo de pesquisa do consumidor, oferecendo maior eficiência ao mercado. Sem dependência dos efeitos de rivalidade e excludência causados pelos bens privados, a propriedade pode ser considerada fator determinante para a contínua propulsão de desenvolvimento econômico.

Como bem esclarecido pelo julgado norte-americano W.T. Rogers Co. v. Keane, 778 F.2d 334, 338 (7th Cir. 1985): “O objetivo [da proteção de marcas] é reduzir o custo de informações aos consumidores, tornando mais fácil para eles para identificar os produtos ou produtores com os quais eles tiveram tanto boas experiências, de modo que eles querem continuar comprando o produto (ou comprando do produtor), ou más experiências, de modo que eles queira evitar que o produto ou o produtor no futuro". ${ }^{230}$

\footnotetext{
${ }^{227}$ Cf. BARBOSA, Denis. Proteção das marcas... Op. cit. p. 169: “O fato de alguém usar uma criação técnica ou expressiva não impossibilita outra pessoa de também fazê-lo, em toda extensão, e sem prejuízo da fruição da primeira".

${ }^{228}$ TIMM, Luciano Benetti, CAOVILLA, Renato e BRENDLER, Gustavo. As teorias rivais sobre Propriedade Intelectual no Brasil. Disponível no link http://www.escholarship.org/uc/item/3fs9d0m3\#page-1. Acessado em 29 de novembro de 2012.

${ }^{229}$ Cf anotou Haroldo Verçosa, "As marcas devem ser verdadeiras, utilizando-se este termo no sentido de “não-deceptivas". Isto porque uma marca pode apresentar um caráter de pura fantasia, não fazendo qualquer referência às características do produto ou serviço que vem a designar, e ainda assim ser verdadeira”. VERÇOSA, Haroldo Malheiros Duclerc: Curso de Direito Comercial vol. 1. Teoria Geral do Direito Comercial e das Atividades Empresariais Mercantis. Introdução à Teoria Geral da Concorrência e dos Bens imateriais. $4^{a}$ Edição atualizada e ampliada. São Paulo: Malheiros, 2011. p. 357. ${ }^{230}$ W.T. Rogers Co. v. Keane, 778 F.2d 334, 338 (7th Cir. 1985): Tradução livre do original: "The purpose [of trademark protection] is to reduce the cost of information to consumers by making it easy for them to identify the products or producers with which they have had either good experiences, so that they want to keep buying the product (or buying from the producer), or bad experiences, so that they want to avoid the product or the producer in the future.").
} 
O consumidor identifica um conjunto de características que procura, sem ter que testá-lo em cada caso, na confiança de que o agente econômico que introduziu o bem no mercado zelará sempre pela coesão e consistência de seus produtos e serviços. ${ }^{231}$ Pela divulgação dessas características, a marca também serve para diminuição da assimetria de informação, tendo em vista que em certos mercados os agentes econômicos precisam despender esforços para fazer chegar mais informação ao consumidor, o qual muitas vezes sabe menos que os próprios vendedores.

\subsection{Função informativa}

Não se pretende aqui estudar a teoria informacional da Propriedade Intelectual, mas somente trazer à baila que a matéria precisa ser revisitada para o aperfeiçoamento da melhor adequação de seus institutos a uma sociedade que vive e consome informação a uma velocidade diferente de quando a propriedade ${ }^{232}$ surge como meio econômico eficaz de se impor limites a titulares rivais.

A marca, sob os olhos da interpretação do sistema proposto por Cláudio BARBOSA, é a informação que pode sinalizar ao consumidor características determinadas de um produto ou serviço. Cada espécie de informação, com suas peculiaridades intrínsecas, pode ser atribuída a uma categoria diferente de direito de propriedade intelectual de forma não exclusiva. ${ }^{233}$

A informação nasce como um bem público, possível de ser utilizada por quem quer que seja, inclusive com fins comerciais. Todavia, na medida em que o uso desenfreado de bens públicos leva a uma tragédia ${ }^{234}$, resultando no seu esgotamento, o sistema jurídico inaugurou uma forma de controle do acesso a esses bens públicos, tornando-os passíveis de captação privada exclusiva. Com esse sistema, entes privados passam a ser capazes de garantir o uso exclusivo de informação, excluindo terceiros dessa

\footnotetext{
${ }^{231}$ BARBOSA, Denis. Proteção das marcas... Op. cit. p.p. 16/17.

${ }^{232}$ Alguns críticos da natureza jurídica de propriedade aposta aos bens intelectuais: Edmond Picard (O Direito Puro, 1877), José de Oliveira Ascensão (Direito de Autor, Ed. Renovar. São Paulo, 1997), Silmara Chinellato (Direito de Autor e Direitos da Personalidade: Reflexões à luz do Código Civil - Tese de Titularidade de Direito Civil da FDUSP - não publicada), Denis Borges Barbosa (Proteção às Marcas. Uma Perspectiva Semiológica. Ed. Lumen Juris. Rio de Janeiro, 2008).

${ }^{233}$ BARBOSA, Cláudio, Op. cit. p. 61.

${ }^{234}$ HARDIN, Garrett. The Tragedy of the Commons. In Science Magazine, vol. 162, n 3859, págs. 1243 $1248,1968$.
} 
utilização rival. ${ }^{235}$ Assim, surge a possibilidade de transformação de um bem público em um privado apto a gerar direitos ao ente ou titular, e efeitos a este e a terceiros.

Tal sistema pode delimitar direitos e deveres tanto às relações jurídicas já tradicionais e analisadas pelos Direito Civil e Comercial - p. ex. propriedade, posse, usucapião etc., como em relações jurídicas menos difundidas como os Direitos Intelectuais $^{236}$ - como vem sendo chamada a ciência das marcas, patentes, desenhos industriais, indicações geográficas - e da Concorrência Desleal.

A teoria da Propriedade Intelectual como informação não só trata os direitos intelectuais como a ciência dos bens intangíveis ${ }^{237}$, mas não deixa de analisá-los como tais, posto sua função econômica e social à luz do CC.

A proteção da informação (aqui, aplica-se o mesmo conceito às marcas e sua distintividade) variará em função de suas características intrínsecas, de características relativas ao próprio criador, e fundamentalmente, variará em função de sua relação com o mercado, pois uma informação poderá ser considerada "bem intelectual" em função dos potenciais efeitos econômicos da informação no mercado produtivo e na geração de novas informações técnicas. ${ }^{238}$

\footnotetext{
${ }^{235}$ COASE, Ronald H: The problem of social costs. In Journal of Law and Economics, 3, $\mathrm{n}^{\circ}$ 1:1-44, 1960. ${ }^{236}$ PICARD. Op. cit. p. 99.

${ }^{237}$ Em virtude da possibilidade de sofrimento de mácula à reputação e à sua integridade material, prefere-se apor a nomenclatura intelectual, advindo da criação humana seja pelo aspecto meramente da forma, como de sua funcionalidade, como é o caso das marcas.

${ }^{238}$ BARBOSA, Cláudio, Op. cit. p. 62.
} 


\section{Capítulo IV \\ OS DIREITOS SOBRE A MARCA}

\section{O sistema de proteção da marca}

De acordo com FRÓES, a marca não resulta necessariamente de uma criação intelectual, mas de uma ocupação de algo que pré-existe ${ }^{239}$. Em complementação, Denis BARBOSA afirma que as marcas estão sujeitas a registro, e completam-se como propriedade industrial a partir do mesmo, não se concebendo, no direito brasileiro vigente, direito natural de ocupação sobre a marca. ${ }^{240}$ No entanto, a partir do depósito haveria uma expectativa de direito, suscetível de proteção possessória. ${ }^{241}$

CORREA é partícipe da idéia de que sempre haverá atividade criativa na concepção de uma marca. Segundo o autor "[s]e é verdade que a doutrina vê, na maioria dos casos, o direito à marca como um direito de ocupação, verdade é, também, que, independentemente das hipóteses de pura criação intelectual (marcas inventadas pelo titular) a própria ocupação de sinal disponível para a designação de determinados bens e serviços já constitui uma inovação semiológica, um uso particular do signo, dentro do qual se derrama novo conteúdo, diverso daquele convencionado, até então, pela cultura".242

Já para Denis BARBOSA, o direito formativo gerador (o direito de postular a propriedade) nasce da ocupação do signo, afetando-lhe a uma atividade específica no âmbito de sua especialidade. Para o autor, cessada a exclusividade e o uso da marca, ela volta a ser res nullius. Denis BARBOSA concorda com CORREA ao comentar que a

\footnotetext{
${ }^{239}$ FRÓES. Op. cit. p. 85.

${ }^{240}$ BARBOSA, Denis. Proteção das marcas. Op. cit. p. 10.

${ }^{241}$ No mesmo sentido, PONTES DE MIRANDA. Tratado... Op. cit. p. 73.

${ }^{242}$ CORREA, José Antonio Faria. A dimensão plurissensorial das marcas: a proteção da marca sonora na lei brasileira. In RABPI, nº 69, mar/abr 2004, p. 19. O contraponto é feito por Newton Silveira: O autor expõe que esse entendimento é seguido por diversos autores e que outros afirmam que a criatividade é mero acidente na escolha da marca, não sendo um produto do engenho humano. O autor é de opinião que as marcas não constituem obras do espírito, mas estão em estreita ligação com a atividade de criar. In:
} SILVEIRA, Newton. Licença de uso de marca e outros sinais distintivos. São Paulo: Saraiva, 1984. pp. 1 e 
ocupação de uma marca pode se dar em face de uma criação, por exemplo, um desenho original. $^{243}$

\subsection{O sistema atributivo de direitos}

O signo é apropriável enquanto jamais tenha sido apropriado por alguém, caracterizada a res nullius. Ou seja, uma marca que nunca foi registrada, em regra, é uma marca sem proprietário, uma marca livre para ser apropriada por quem primeiro registrar, com a exceção do direito do usuário anterior de boa-fé. ${ }^{244}$

Com o intuito de demonstrar que o sistema de marcas precisa obedecer ao sistema atributivo de direitos, Wilson JABUR cita José Antonio Faria CORREA (1991, pp. 261/263), que assevera que "[o] princípio da atributividade do registro nada mais é do que expressão particular da máxima 'prior in tempore, potior in jure'. Todavia, essa máxima, para valer, depende da presença de um postulado mais alto: o postulado da boafé, de conteúdo axiológico mais alto. Quando a lei brasileira consagra a prioridade do registro, parte da premissa de que o requerente satisfaz, também, o princípio mais elevado; funda-se na presunção de que o pedido é sincero, ou seja, que o requerente, realmente, tem direito formativo gerador à aquisição do título de propriedade que a Lei exige para garantir as diferentes ações que define. É a regra de que a fraude mancha tudo: "fraus omnia corrumpit. O regime do registro atributivo não foi criado para agasalhar a fraude no comércio, para premiar a astúcia. Foi criado, isto sim, para disciplinar com clareza e segurança as relações entre os concorrentes. Efetuar registro de marca que se sabe de terceiro constitui nítido abuso de direito. Significa empregar a norma jurídica para finalidade diversa daquela pretendida pelo legislador". 245

O sistema de marcas é justificado, na visão de Denis BARBOSA, em virtude de sua finalidade de proteção ao investimento do empresário. Assim, apropriada pelo sistema jurídico em favor de seu titular, a marca se destina a assegurar o investimento no

\footnotetext{
${ }^{243}$ BARBOSA, Denis. Proteção das marcas. Op. cit. p. 229, nota 25.

${ }^{244}$ BARBOSA, Denis. Proteção da marca... Op. cit. p. 229.

245 JABUR, Wilson Pinheiro. Nomes de domínio. Novo sinal distintivo? In: SANTOS, Manoel J. Pereira dos e JABUR, Wilson Pinheiro (Orgs.). Sinais Distintivos e Tutela Judicial e Administrativa. Série GVLaw. São Paulo: Saraiva, 2007. pp. 300/301.
} 
valor concorrencial da imagem que a atuação específica da empresa, identificada pelo signo, adquire junto aos consumidores. ${ }^{246}$

De acordo com SCHMIDT, o depósito de uma marca pode configurar abuso de direitos. Como a pirataria é sempre uma ilicitude e não um direito, o abuso de que se cuida é do abstrato direito de petição aos órgãos públicos, pelo desvirtuamento de sua finalidade. Isso ocorrerá sempre que a marca pretendida constituir um instrumento para a prática de atos de concorrência desleal. Toda a atuação do INPI deve estar voltada para impedir o favorecimento à concorrência desleal. ${ }^{247}$

Há um interesse geral em que uma marca seja registrada. No entanto, é de notar-se que o segundo criador de uma mesma marca tem idêntico direito, desde que a criação seja autêntica, ou seja, de boa-fé. O princípio prior in tempore fortior in jure (primeira no tempo, mais forte em direito), por mais ecos de metadireito que possa ter, não consagraria, para sempre e incondicionalmente, o direito de quem, livre para postular "o registro para a tutela comercial e para eficácia própria da publicidade", não o fez, deixou de fazê-lo voluntariamente, ou por inércia. Ao dito romano se anteporia outro, de idêntico pedigree: dormientibus non sucurrit jus (o direito não socorre aqueles que se omitem). ${ }^{248}$

\subsubsection{O processo administrativo de registro de marca}

O procedimento administrativo de registro de marca é conduzido pelo INPI, autarquia criada pela Lei $\mathrm{n}^{\circ} 5.648 / 70$, o qual possui formalidades de trâmite, que devem ser obedecidas pelos titulares de marcas. Antes de ser apresentado o depósito do pedido de registro, deve-se classificar os produtos ou serviços a serem assinalados pela marca, de acordo com a Classificação adotada pelo INPI. ${ }^{249}$ Para tanto, os titulares de marcas precisam escolher uma lista de tais produtos e/ou serviços, os quais devem estar previstos no objeto social da empresa em cujo nome a marca será requerida, de acordo com o artigo

\footnotetext{
${ }^{246}$ BARBOSA, Denis. Proteção das marcas. Op. cit. pp. 10/12/13.

${ }^{247}$ SCHMIDT, Lélio Denícoli. Princípios Aplicáveis... Op. cit. p. 38.

${ }^{248}$ BARBOSA, Denis. Proteção das marcas... Op. cit. p. 383.

${ }^{249}$ O Brasil adotou a classificação internacional de produtos e serviços, aderindo ao Acordo de Nice em 1999, o qual, naquele momento, encontrava-se em sua $7^{a}$ edição. Em 2012, o INPI já havia implementado a $10^{\mathrm{a}}$ edição da classificação internacional de produtos e serviços.
} 
128 da LPI. ${ }^{250}$ De acordo com as normas do INPI, cada pedido de registro pode abranger produtos ou serviços de 1 (uma) única classe; caso produtos ou serviços incluídos em mais de uma classe devam ser reivindicados, serão necessários pedidos de registro adicionais. Cada pedido de registro tem um processamento independente e pode ocorrer que a marca seja deferida em uma determinada classe e indeferida em outra.

Cerca de 2 meses após o depósito, o pedido de registro de marca é publicado na RPI, abrindo-se um prazo de 60 dias durante o qual terceiros podem apresentar oposições. Findo este prazo, tenha sido ou não apresentada qualquer oposição, o pedido é minuciosamente analisado pelo INPI, levando-se em conta a distintividade da marca objeto do artigo 124, inciso VI da LPI, bem como a anterioridade de outros pedidos e/ou registros semelhantes ou idênticos, de acordo com o artigo 124, inciso XIX da LPI.

Como consequência do exame, uma decisão é publicada na RPI, que poderá ser a de deferimento, indeferimento ou suspensão do pedido. Se o exame do pedido revelar outros pedidos anteriores conflitantes com o novo, o mesmo ficará em suspenso até que uma decisão a respeito do pedido inviabilizador seja publicada na RPI. Entretanto, se o exame preliminar apontar a existência de alguma proibição legal ao seu registro ou a existência de conflito com uma marca já registrada, o pedido poderá ser indeferido. Da decisão que indefere o pedido é aberto o prazo de 60 dias para que o depositante interponha recurso. Da decisão de deferimento não cabe recurso por terceiros.

Com a decisão de deferimento, abre-se simultaneamente o prazo de 60 dias para pagamento das taxas finais que se destinam à emissão do respectivo Certificado de Registro e sua manutenção. Caso as taxas finais não sejam pagas nessa oportunidade, ainda será possível completar o processamento do pedido de registro através do pagamento de taxas suplementares, nos 30 dias subsequentes. Se as taxas finais não forem pagas nos 90

\footnotetext{
${ }^{250}$ Art. 128 LPI. "Podem requerer registro de marca as pessoas físicas ou jurídicas de direito público ou de direito privado. $\S 1^{\circ}$ As pessoas de direito privado só podem requerer registro de marca relativo à atividade que exerçam efetiva e licitamente, de modo direto ou através de empresas que controlem direta ou indiretamente, declarando, no próprio requerimento, esta condição, sob as penas da lei. $\S 2^{\circ} \mathrm{O}$ registro de marca coletiva só poderá ser requerido por pessoa jurídica representativa de coletividade, a qual poderá exercer atividade distinta da de seus membros. $\$ 3^{\circ} \mathrm{O}$ registro da marca de certificação só poderá ser requerido por pessoa sem interesse comercial ou industrial direto no produto ou serviço atestado. $\S 4^{\circ} \mathrm{A}$ reivindicação de prioridade não isenta o pedido da aplicação dos dispositivos constantes deste Título".
} 
dias subsequentes à publicação do deferimento o pedido de registro será definitivamente extinto.

Por outro lado, se o pedido de registro tiver sido indeferido e tiver havido recurso, caso a decisão no recurso (que demora cerca de outros 3 anos para ser proferida) for favorável ao depositante, estará então aberto o prazo para pagamento das taxas finais, conforme explicado acima.

Uma vez pagas as taxas finais, o registro da marca é concedido e o titular notificado, através de outra publicação na RPI. O Certificado é então emitido e entregue ao titular pelo INPI. Em 2012, o INPI levava cerca de 2 anos para cumprir o processamento acima, desde que não tivesse ocorrido incidentes como oposições de terceiros, exigências ou ainda, ocorrência de recursos contra o indeferimento do pedido.

Dentro do período de 180 dias contados a partir da data da publicação da concessão do registro, é facultado a terceiros (ou mesmo ao INPI), insurgir-se contra esta concessão e tentar cancelar o registro concedido através da instauração de um processo de nulidade administrativa da decisão que concedeu o registro. Os titulares são avisados sempre que é iniciado um processo de anulação administrativa do registro através de publicação na RPI e desta publicação corre o prazo de 60 dias para que o titular se manifeste contra este pedido de anulação, contestando os argumentos levantados no mesmo. A decisão referente ao processo de anulação é também publicada na RPI, sendo a mesma final na esfera administrativa.

\subsection{O uso como formador do direito}

O uso, em certas jurisdições, é pressuposto ou requisito da aquisição do direito exclusivo à marca; não assim no Brasil. Veja pelo direito norte-americano. O requerente nacional de marca é obrigado a utilizá-la antes de requerê-la ao USPTO ${ }^{251}$. Embasado no sistema de Common Law, os Estados Unidos exigem que haja o reconhecimento da marca pelo público, constituindo fato jurídico imantando o direito de aquisição da mesma.

${ }^{251}$ KELLY, David M. and MONDINI, Andrea V: Intend to use it or lose it. In: RABPI v. 24. Rio de Janeiro: ABPI, set/out 2006. p. 41. 
Já para o titular estrangeiro que deseje registrar sua marca nos Estados Unidos, não é exigido o mesmo requisito, mas apenas uma declaração de que irá utilizar a marca. ${ }^{252}$ Mesmo assim, a legislação americana exigirá o uso da marca do estrangeiro antes que a mesma seja definitivamente concedida pelo USPTO. Caso contrário, o órgão entenderá que houve evidência de abandono da marca pelo interessado. ${ }^{253}$

Com o intuito de impor o sistema atributivo de direito ao sistema de marcas, a legislação criou exceção de proteção, que de um lado privilegia o princípio atributivo, reputando o registro (e não o uso) como elemento constitutivo do direito de propriedade sobre a marca ${ }^{254}$, e de outro turno, introduz alguns contrapesos, reconhecendo que determinadas situações originam um direito de preferência à obtenção do registro, como pré-uso da marca por boa-fée ${ }^{255}$, sua notoriedade ${ }^{256}$, seu prévio registro como nome empresarial $^{257}$.

No que tange ao direito de preferência ao registro por uso anterior por boa-fé, há histórica discussão doutrinária e jurisprudencial quanto ao momento de se arguir tal direito. A hipótese é simples já que a lei confere ao utente de boa-fé a possibilidade de provar tal uso que tem que datar pelo menos 6 (seis) meses antes da data de apresentação do pedido junto ao INPI. A prova de uso mais antiga ganha. Entretanto, o cerne da questão se concentra em uma passagem do artigo $129 \S 1^{\circ}$ da LPI que diz: “(...) terá direito de precedência ao registro". Aos olhos de boa parte da doutrina e de examinadores do INPI, o pré-uso de boa-fé só poderá ser invocado antes do momento em que a marca de interesse seja concedida ao titular que a requereu perante a autarquia. A outra parte entende que, independentemente do momento processual, ao pré-utente é garantido o direito

\footnotetext{
${ }^{252}$ Lanham Act $\S 44(\mathrm{e}), 15$ U.S.C. $§ 1126(\mathrm{e})$ : “the applicant must sign a sworn statement confirming its bona fide intention to use the mark in commerce in the Unitd States".

${ }^{253}$ Lanham Act § 45, 15 U.S.C. § 1127.

${ }^{254}$ Art. 129 LPI. Vide nota 52.

${ }^{255}$ Art. 129, $\$ 1^{\circ}$ LPI. “ $\$ 1^{o}$ Toda pessoa que, de boa fé, na data da prioridade ou depósito, usava no País, há pelo menos 6 (seis) meses, marca idêntica ou semelhante, para distinguir ou certificar produto ou serviço idêntico, semelhante ou afim, terá direito de precedência ao registro”.

${ }^{256}$ Art. 126 LPI. "A marca notoriamente conhecida em seu ramo de atividade nos termos do art. $6^{\circ}$ bis (I), da Convenção da União de Paris para Proteção da Propriedade Industrial, goza de proteção especial, independentemente de estar previamente depositada ou registrada no Brasil. $\$ 1^{\circ}$ A proteção de que trata este artigo aplica-se também às marcas de serviço. $\$ 2^{\circ} \mathrm{O}$ INPI poderá indeferir de ofício pedido de registro de marca que reproduza ou imite, no todo ou em parte, marca notoriamente conhecida".

${ }^{257}$ Art. 124 LPI. "Não são registráveis como marca. $\boldsymbol{V}$ - reprodução ou imitação de elemento característico ou diferenciador de título de estabelecimento ou nome de empresa de terceiros, suscetível de causar confusão ou associação com estes sinais distintivos; ”.
} 
constitucional de petição e seu direito de preferência ao registro poderá ser fundamentado a qualquer tempo.

No entanto, outras importantíssimas conseqüências resultam do uso do signo distintivo: a proteção da marca não registrada pela concorrência desleal e as hipóteses possessórias de manutenção ou perda de direitos.

A precedência no ato do depósito do pedido de registro de marca é importante, mas não determinante. Na visão de Newton SILVEIRA, as marcas sem registro não deixam o utente desamparado, posto que este se socorre das normas de repressão a concorrência desleal. ${ }^{258}$ Continua o autor esclarecendo sob à luz da lição de Bonasi BENUCCI que " $[u]$ m elemento provido de eficácia distintiva e não registrado assegura ao seu titular uma tutela contra o perigo de confusão entre produtos ou atividades, tutela que deriva das normas sobre concorrência desleal e não daquelas sobre a marca". 259

\section{Direito de uso exclusivo}

Há muito se discute sobre a verdadeira natureza jurídica da proteção da marca. Desde o século XIX, o Brasil tem adotado leitura constitucional sobre o tema e tem definido a natureza de proteção das marcas como de propriedade.

Como já exposto, existem muitas críticas sobre essa análise, como a temporariedade de vigência de uma marca frente à característica atemporal que a propriedade empresta ao direito. Além de tudo, é de se salientar que, de acordo com o Código Civil, propriedade só recai sobre bens materiais, imóveis ou móveis, sendo que os bens imateriais são deixados de lado por nosso Código.

\footnotetext{
${ }^{258}$ SILVEIRA, Netwon. Curso... Op. cit. p. 36. No mesmo sentido, Luiz Leonardos comenta que "Basta-nos lembrar que, em virtude do relacionamento entre as relações jurídicas da propriedade industrial e da concorrência desleal, mesmo quando não existe registro, ainda tem o interessado a seu dispor a ação da concorrência desleal”. In: LEONARDOS, Luiz. A proteção das marcas não registradas no Brasil e no Mercosul. In: RABPI. v. 34. p. 33. Rio de Janeiro: ABPI, 1998.

${ }^{259}$ SILVEIRA, Newton. Licença... Op. cit. p. 44.
} 
Sobre a abrangência do direito de uso exclusivo assim previsto na lei, GAMA CERQUEIRA $^{260}$ escreveu que o direito de uso exclusivo, assegurado ao titular do registro, importa, em seu aspecto negativo, o de impedir que terceiros empreguem marcas idênticas ou semelhantes à sua. Como conseqüência, o titular do registro dessas marcas pode anular o registro que tenha sido feito em desacordo com a lei, bem como processar judicialmente quem força uso de marca infringente do registro.

No mesmo sentido, SCHMIDT anota que como a proteção não recai sobre a marca em si, enquanto sinal isoladamente considerado, mas sobre o seu uso para identificar determinado produto ou serviço, nada impede que a marca seja formada por palavras comuns e usuais, integrantes do vocabulário. ${ }^{261}$

Todavia, FRANCESCHELLI recomenda analisar que a proteção sobre a marca é dotada de um certo tom de elasticidade quando comenta que "[p]or este conceito de afinidade [...], o âmbito de protecção da marca é estendido e previsto de um certo elemento de elasticidade em função do critério do julgamento do mercado". ${ }^{262}$

Administrativamente, o artigo 129 da LPI cristaliza o princípio da anterioridade, o qual estabelece a preferência da análise de pedidos de registro de marca de acordo com a antecedência temporal da data do depósito do pedido junto ao órgão responsável. Dessa forma, tal princípio, no Brasil, exige que o titular de marca, desejoso de obter o direito de uso exclusivo em todo território nacional para sua marca, apresente seu pleito ao INPI, submetendo-o a um procedimento administrado pela autarquia federal.

Interessante notar que o direito de uso exclusivo não recai sobre a marca propriamente dita, mas sobre o direito de apô-la aos produtos e serviços designados pelo registro concedido pelo Estado. Nessa linha, Newton SILVEIRA afirma que "o direito

\footnotetext{
${ }^{260}$ CERQUEIRA. Tratado... Op. cit. p. 843.

${ }^{261}$ SCHMIDT. Marcas em semiótica... Op. cit. p. 48. No mesmo sentido, MATHÉLY, Paul. Op. cit.

${ }^{262}$ FRANCESCHELLI, Remo: Sui marchi di impresa. 4ª edição atual. Milão: Giuffrè, 1988: p. 347.

Traduzido livremente do original: [a] ttraverso questo concetto di affinitá [...] l'ambito della protezione del marchio viene ampliato e provisto di um certo elemento di elasticitá in funzione del critério del giudizio del merchato".
} 
sobre o sinal, decorrente do registro, corresponde à aplicação, com exclusividade, sobre determinada categoria de produtos ou artigos abstratamente considerados". ${ }^{263}$

\subsection{Os limites ao direito de uso exclusivo}

$\mathrm{O}$ registro concede ao titular direitos de propriedade sobre a marca, com a faculdade de utilizá-la em produtos/serviços e documentos referentes à sua atividade; zelar pela integridade material e reputação da marca; opor-se à concessão de registros colidentes com o seu; e coibir atos de contrafação, através de medidas judiciais pertinentes.

Com os direitos em linha, necessário se faz comentar que os mesmos não geram efeitos absolutos em termos de defesa da marca.

\subsubsection{O princípio da especialidade}

O direito de uso exclusivo de uma marca registrada não é ilimitado. Um dos limites consiste na especificação da área de atuação em que o titular escolhe para o uso de sua marca. Dessa forma, é obrigatória a designação de uma atividade empresarial definida por uma lista de produtos ou serviços, a qual precisa constar do formulário de depósito do pedido perante a autarquia.

A nossa legislação vem a muito delimitando o direito de uso exclusivo sobre as marcas nesse aspecto. O artigo 89 do Código da Propriedade Industrial de 1945 expressava que: "As marcas registradas, de acordo com este Código, terão garantido o seu uso exclusivo para distinguir produtos ou mercadorias, de outros idênticos ou semelhantes, de procedência diversa". Já o artigo 59 do CPI expressava que: "Será garantida no território nacional a propriedade da marca e o seu uso exclusivo àquele que obtiver o registro de acordo com o presente Código, para distinguir seus produtos, mercadorias ou serviços de outros idênticos ou semelhantes, na classe correspondente à sua atividade”.

\footnotetext{
${ }^{263}$ SILVEIRA, Newton. Licença... Op. cit. p. 26. No mesmo sentido, PÉROT-MOREL, Marie-Angèle: L'opposabilité dês antériorités em matière de marque de fabrique, de commerce ou de service. In: Revue Trimestrielle de Droit Commercial, ano 24, v. 2, abr/jun 1971, p. 248.
} 
Nota-se que com mais precisão jurídica, a Lei de 1945 trouxe os limites de proteção à marca dentro dos parâmetros de suas funções. Veja-se também que o Código de 1945 deixa de entrar na seara da natureza jurídica da proteção à marca, limitando-se a despejar o direito de uso exclusivo, e não propriedade conforme preceitua o Código de 1971.

Já a LPI (lei em vigor no país), dispõe o limite de proteção ao direito de uso exclusivo de uma marca de maneira negativa ${ }^{264}$ deixando para inciso XIX do artigo 124 a proibição de registro de marca "[r]eprodução ou imitação, no todo ou em parte, ainda que com acréscimo, de marca alheia registrada, para distinguir ou certificar produto ou serviço idêntico, semelhante ou afim, suscetível de causar confusão ou associação com marca alheia".

Aqui percebe-se que o conceito de especialidade torna-se mais amplo do que simplesmente "produtos idênticos ou semelhantes" como diziam as antigas leis de Propriedade Industrial, já que as noções de confusão e associação foram inseridas no ordenamento de modo a interpretar o limite da especialidade à propriedade sobre a marca sob o ponto de vista do consumidor. Parece que as legislações antigas já traziam preocupação sobre os riscos de coexistência de marcas que possibilitavam que o consumidor se confundisse. Porém, com o advento do Código de Defesa do Consumidor de 1990, a legislação de Propriedade Industrial inseriu de vez a proteção da marca sob os olhos do consumidor e o risco ao mercado.

A doutrina denominou tal limite como o princípio da especialidade, o qual é imposto pela LPI de forma negativa, como explicado por GAMA CERQUEIRA, ao proibir o registro de marca que reproduza ou imite registro de terceiro já concedido para designar produtos ou serviços idênticos, afins ou relacionados ao listado pelo novo pedido.

O campo da especialidade é definido, primariamente, pelo espaço da concorrência; remete-se diretamente à definição do mercado pertinente. No entanto, tratando-se de símbolos e não de fluxo primário da economia, há - além do efeito primário

\footnotetext{
${ }^{264}$ Tendo em vista que o artigo 129 dispõe meramente que "A propriedade da marca adquire-se pelo registro validamente expedido, conforme as disposições desta Lei, sendo assegurado ao titular seu uso exclusivo em todo o território nacional (...)".
} 
de vinculação a uma utilidade - extravasamento do efeito simbólico em face da utilidade do produto marcado. ${ }^{265}$

No entendimento de Newton SILVEIRA, a marca não precisa ser nova em absoluto, podendo a mesma ser idêntica a de terceiros, mas ela precisa se destinar a assinalar produtos que não sejam concorrentes. ${ }^{266}$

Na prática, o pedido de registro de marca é submetido ao INPI com uma lista de produtos ou serviços de uma classe ${ }^{267}$, e após pesquisa conduzida pelos Examinadores de Marcas na base de dados do órgão, o pedido novo é analisado levando-se em consideração as anterioridades em vigor.

Ademais, o princípio da especialidade é analisado de forma subjetiva pelos examinadores de marcas do INPI, pois trata-se de exercício empírico de interpretação sobre eventual relacionamento entre produtos e/ou serviços designados pelas marcas em cotejo. O que se vê das decisões do INPI, desde a adoção da classificação internacional de produtos e serviços, é a aplicação do princípio com maior flexibilidade, tendo em vista a crescente especificidade das atividades empresariais.

Antes de 1999, era comum perceber decisões de indeferimento de pedidos de registro de marca do ramo alimentício, com base em anterioridades que designavam quaisquer alimentos, independentemente da sua natureza. São exemplos fictícios de conflito aplicados pelo INPI até 1999: Tomate $v s$. farinha. Laticínios vs. temperos.

Newton SILVEIRA cita um caso interessante sobre a marca PALHINHA. O antigo TFR decidiu, em 1953, e o STF, em 1978, confirmou, que duas marcas idênticas "PALHINHA", uma para designar bebidas alcoólicas e a outra, designando vinagre, poderiam conviver. Apesar desse entendimento, como contraponto, Newton SILVEIRA transcreve o manifestado por Waldemar FERREIRA contra tal decisão: "Não tomaram

\footnotetext{
${ }^{265}$ BARBOSA, Denis. Proteção das marcas... Op. cit. p. 60. “A especialidade não é um fenômeno estático ou genérico; ao contrário, o que pode ser colidente num mercado europeu, com métodos de distribuição próprios, pode não ser no americano. O que pode ser colidente hoje, não era há dez anos".

${ }^{266}$ SILVEIRA, Newton. Curso... Op. cit. p. 20.

${ }^{267}$ As classes de produtos e serviços são administradas pelo Acordo Internacional de Nice, internalizado pelo Brasil através do Ato Normativo INPI n ${ }^{\circ} 150 / 99$. Atualmente, a classificação de produtos e serviços encontra-se em sua $9^{\text {a }}$ Edição.
} 
tento da afinidade dos produtos; e a entre vinagre e as bebidas alcoólicas é tanta que vinagre é o vinho acre ou azedo, como a própria palavra indica", 268

Tal prática interpretativa levava os usuários do sistema de marcas e estudiosos a afirmar que a classificação de produtos e serviços que vigorava à época era mais proibitiva, pois amparava os registros de forma mais alargada. O que existia, em verdade, era a proteção da marca por feudos de atividade. Hoje em dia, em virtude da descrição dos produtos e serviços, a classificação de produtos e serviços evoluiu, diminuindo os limites da aplicação do princípio da especialidade.

Como a marca se refere à origem dos produtos ou serviços, a prática de alargamento da linha de produtos ou serviços de uma mesma origem, efetuada como padrão de mercado, os limites de uma especialidade determinada podem se deslocar, inclusive por associação.

Portanto, o princípio da especialidade não legitima a prática de atos parasitários, mesmo em situações de concorrência sem concorrência. Outrossim, é interessante notar que a marca famosa constitui exceção, pois excepciona os princípios da especialidade e permite que marcas famosas sejam protegidas, ainda que em segmentos não explorados por seus titulares.

\subsubsection{A exceção ao princípio da especialidade}

Toda regra tem sua exceção e a do princípio da especialidade é a marca de alto renome, que merece proteção em todas as atividades empresariais, de acordo com o artigo 125 da LPI. $^{269}$ É a marca largamente difundida e, inescusavelmente conhecida pelo público, de fácil associação ao produto correspondente, exercendo um grande fascínio e enorme poder de atração diante de consumidor. Tal proteção visa a impedir que terceiros possam tirar proveito de marcas já consagradas, coibindo a má-fé.

\footnotetext{
${ }^{268}$ SILVEIRA, Newton. Curso... Op. cit. p. 66.

${ }^{269}$ Art. 125 LPI: “À marca registrada no Brasil considerada de alto renome será assegurada proteção especial, em todos os ramos de atividade”.
} 


\subsubsection{O princípio da territorialidade}

O princípio da territorialidade atribui proteção no país onde foi registrada a marca. A CUP estabelece, à luz desse princípio, que "[u]ma marca registrada em um país da União será considerada como independente das marcas registradas nos outros países da União inclusive o país de origem". ${ }^{270}$ Por via de conseqüência, nos países onde não tiver sido registrada, a marca não gozará de proteção e poderá ser apropriada.

Em consonância com o princípio, a LPI estabelece, de acordo com o seu artigo 129, que o registro de marca assegura "ao titular seu uso exclusivo em todo o território nacional (...)".

\subsubsection{A exceção ao princípio da territorialidade}

A exceção ao princípio da territorialidade acima descrito está prevista no artigo 6 Bis da Convenção União de Paris (CUP $)^{271}$, segundo o qual não se permitirá o uso ou registro de marca que reproduza, imite ou traduza ou possa estabelecer confusão com marca notoriamente conhecida em seu ramo de atividade. Essa proteção é acolhida pela LPI, em seu artigo $126 .{ }^{272}$

As Diretrizes de Análise de Marcas do INPI, publicada em 17 de dezembro de 2010 salienta que a CUP não definiu notoriedade e nem estabeleceu parâmetros para análise desse status e dessa forma, o INPI "considera a questão observando se a marca possui certo conhecimento, no Brasil, no segmento de mercado idêntico ou similar. A aplicação da norma citada pode dar-se de ofício ou a requerimento do interessado. Ela

\footnotetext{
${ }^{270}$ Art. 6 (3) da CUP.

${ }^{271}$ Artigo 6 bis CUP. “1) Os países da União comprometem-se a recusar ou invalidar o registro, quer administrativamente, se a lei do país o permitir, quer a pedido do interessado, e a proibir o uso de marca de fábrica ou de comércio que constitua reprodução, imitação ou tradução, suscetíveis de estabelecer confusão, de uma marca que a autoridade competente do país do registro ou do uso considere que nele é notoriamente conhecida como sendo já marca de uma pessoa amparada pela presente Convenção, e utilizada para produtos idênticos ou similares. O mesmo sucederá quando a parte essencial da marca constitui reprodução de marca notoriamente conhecida ou imitação suscetível de estabelecer confusão com esta"
}

${ }^{272}$ Artigo 126 LPI. Vide nota 251. 
poderá ocorrer de ofício quando o examinador julgar que a notoriedade é suficiente a ponto de dispensar a produção de provas". ${ }^{273}$

\subsubsection{As hipóteses de uso legítimo de marca de terceiro}

O direito de uso exclusivo de uma marca também é limitado ao que se chama de fair use, ou uso de boa-fé. O artigo 132 da LPI ${ }^{274}$ lista as possibilidades de utilização de uma marca de terceiro sem que isso signifique uso indevido, à luz do artigo 189 e seguintes da LPI. Eis algumas situações fáticas trazidas pelos incisos do referido artigo:

(i) inciso I: não há nada que impeça um comerciante ou distribuidor de colocar, ao lado da marca do produto que comercializa, sinal distintivo de seu estabelecimento;

(ii) inciso II: é assegurado ao fabricante de acessórios, por exemplo: autopeças, utilizar determinada marca para indicar para quais veículos as referidas peças são produzidas;

(iii) inciso III: o titular da marca não pode impedir que o produto com a sua marca seja revendida no mercado ${ }^{275}$;

(iv) inciso IV: a marca registrada pode ser citada em discursos, obras literárias, científicas e outras publicações, desde que tais usos não causem prejuízo ao caráter distintivo da marca, nem tenham conotação comercial.

A preocupação do legislador ao instituir estas limitações foi a de impedir que titulares de registros de marcas utilizassem os seus direitos de forma indiscriminada, sem considerar determinadas práticas lícitas de concorrentes e de terceiros em geral. A lei garante direitos aos titulares de marcas, entretanto, o registro concedido pelo INPI não lhes confere a possibilidade de adotar medidas coercitivas em toda e qualquer situação.

\footnotetext{
${ }^{273}$ http://www.inpi.gov.br/images/stories/downloads/pdf/diretrizes_de_analise_de_marcas_17-12-2010.pdf. Acessado em 03/11/2011.

${ }^{274}$ Artigo 132 LPI: $O$ titular da marca não poderá: I-impedir que comerciantes ou distribuidores utilizem sinais distintivos que lhes são próprios, juntamente com a marca do produto, na sua promoção $e$ comercialização; II - impedir que fabricantes de acessórios utilizem a marca para indicar a destinação do produto, desde que obedecidas as práticas leais de concorrência; III - impedir a livre circulação de produto colocado no mercado interno, por si ou pro outrem com seu consentimento, ressalvado o disposto nos $\$ 3^{\circ} e$ $4^{\circ}$ do artigo 68; e IV-impedir a citação da marca em discurso, obra científica ou literária ou qualquer outra publicação, desde que sem conotação comercial e sem prejuízo para seu caráter distintivo."

${ }^{275}$ Esse dispositivo legal dispara a discussão conturbada sobre o princípio da exaustão e as importações paralelas.
} 


\section{Demais direitos sobre a marca}

Seguindo as características do direito de propriedade sobre bens materiais, a marca, além do direito de usá-la de forma exclusiva pelo prazo de 10 anos prorrogáveis por períodos iguais e sucessivos, o titular da marca pode dispor dela e licenciar seu uso a terceiros de seu interesse.

\subsection{Direito de dispor da marca}

De acordo com artigo 134 da LPI $^{276}$, o titular de pedidos de registro de marca ou registros já concedidos pode cedê-los, desde que o cessionário atenda aos requisitos legais para requerer tal registro. Essa é uma regra especial em função da natureza jurídica limitadora de atuação das marcas. Seguindo o preceito do artigo 128 da LPI $^{277}$, o cessionário deve comprovar que pode exercer lícita e efetivamente a atividade designada pela marca a ser transferida à sua titularidade.

Outra regra imposta pela lei é a do artigo $135^{278}$, o qual condiciona a transferência da marca desejada a todas as outras, sejam registros ou pedidos, que estejam em nome do cedente, iguais ou semelhantes, relativas a produto ou serviço idêntico, semelhante ou afim, sob pena de cancelamento dos registros ou arquivamentos dos pedidos não cedidos. A ideia dessa regra especial é manter a consistência do impedimento do artigo 124, XIX da LPI, protegendo a concorrência ${ }^{279}$, o consumidor e o titular da marca cedida. Fosse permitida a cessão indiscriminada de marcas, aviltando a possibilidade de marcas idênticas restarem sob titularidade de agentes econômicos distintos, o consumidor seria prejudicado com a inexatidão da origem dos produtos ou serviços.

Importante notar que o dever de transparência deve permear os negócios entre cedente e cessionário. Na visão de DANNEMANN, "[O] cedente deve informar ao

\footnotetext{
${ }^{276}$ Art. 134 LPI. “O pedido de registro e o registro poderão ser cedidos, desde que o cessionário atenda aos requisitos legais para requerer tal registro”.

${ }^{277}$ Art. 128 LPI. Vide nota 249.

${ }^{278}$ Art. 135 LPI. Vide nota 122.

${ }^{279}$ BARBOSA, Denis Borges. Uma Introdução à Propriedade Intelectual, $2^{\text {a }}$ Ed., Rio de Janeiro: Lumen Júris, 2003. p. 265.
} 
cessionário, através de declaração escrita no próprio contrato, sobre todos os vícios da marca, como, por exemplo, o não uso por período superior a cinco anos elou sua penhora". ${ }^{280}$ No caso de desuso da marca pelo período de 5 anos, a mesma fica sujeita a pedidos de caducidade e tal qual qualquer transferência de propriedade, o cessionário herda todos os vícios do bem cedido.

As cessões de marcas podem ocorrer por incorporação ou fusão de duas ou mais empresas, por cisão, por sucessão legítima ou testamentária ou em decorrência de falência do cedente. ${ }^{281}$ As cessões devem ser anotadas pelo INPI $^{282}$ e só surtirão efeitos erga omnes após a sua publicação pelo INPI $^{283}$, que mantém manual com todos os requisitos e documentos necessários na internet à disposição da sociedade. ${ }^{284}$

\subsection{Direito de licenciar a marca}

Dentre seus deveres, o INPI precisa impulsionar o conhecimento sobre Propriedade Industrial e ainda promover conhecimento sobre as formas legais de se aproveitar o sistema. Dessa forma, o INPI mantém em seu website informações gerais sobre a possibilidade de se licenciar o uso de marcas, sejam registros ou pedidos. De acordo com o órgão, "[P]ara que estas transações (licenciamento) sejam seguras $e$ permitam até envio de royalties para o exterior, existem contratos que devem ser averbados/registrados no INPI. Os contratos incluem desde licenciamento de patentes, desenhos industriais e uso de marca até assistência técnica e know-how. Sem contar as franquias, cujo registro, embora seja opcional, garante um acordo seguro e confere validade perante terceiros ". ${ }^{285}$

\footnotetext{
${ }^{280}$ DANNEMANN. Op. cit. pp. 270/271.

${ }^{281}$ DANNEMANN. Op. cit. p. 273.

${ }^{282}$ Art. 136 LPI. “O INPI fará as seguintes anotações: I - da cessão, fazendo constar a qualificação completa do cessionário;(...)”.

${ }^{283}$ Art. 137 LPI. "As anotações produzirão efeitos em relação a terceiros a partir da data de sua publicação".

${ }^{284}$ Disponível no link

http://www.inpi.gov.br/images/stories/downloads/pdf/diretrizes_de_analise_de_marcas_17-12-2010.pdf. Acessado em 30 de novembro de 2012.

${ }^{285}$ Disponível no link http://www.inpi.gov.br/portal/artigo/guia_basico_contratos_de_tecnologia. Acessado em 30 de novembro de 2012.
} 
De acordo com o artigo 139 da LPI, o titular de registro ou o depositante de pedido de registro poderá licenciar uso da marca, sem prejuízo de seu direito de exercer controle efetivo sobre as especificações, natureza e qualidade dos respectivos produtos ou serviços.

De pronto, já percebe-se que, mediante o controle de qualidade dos produtos ou serviços licenciados, o titular da marca pode sofrer prejuízos quanto à integridade material da mesma, dependendo da atuação do licenciado contratado. Assim, não há como se descartar a hipótese de um contrato de licença de uso de marca gerar consequências negativas em relação à integridade material da marca e reputação do titular do registro ou depositante do pedido.

Nesse diapasão, Douglas G. DOMINGUES escreveu que "o licenciado deve obrigar-se a zelar pela integridade material da marca elou reputação da marca que usa, mas não lhe pertence, porque, na eventualidade da marca licenciada ser usada com modificação que implique alteração de seu caráter distintivo original, tal como constante do certificado de registro, caducará o registro ex vi inciso II do art. 143". ${ }^{286}$

A preocupação do autor é honrosa, mas talvez o objetivo do artigo 130 inciso III da LPI seja mais amplo do que apenas evitar a caducidade da marca utilizada, tendo em vista a alteração de sua característica distintiva. O presente estudo defende que a noção de integridade material é muito mais ampla, sendo que a mesma açambarca tanto o caráter distintivo intrínseco da marca, como o extrínseco. Logo, o licenciado deve proteger a integridade material da marca licenciada em todos os cenários possíveis de prejuízo da mesma. Por hipótese, se o licenciado tiver notícia de uso da marca como sinônimo do gênero do produto designado, o mesmo deverá informar o licenciante para que medidas corretivas sejam tomadas contra esse uso vulgarizador.

\footnotetext{
${ }^{286}$ DOMINGUES, Douglas Gabriel. Comentários à Lei da Propriedade Industrial. Rio de Janeiro: Forense, 2009. p. 475.
} 
O artigo 140 da LPI diz que "o contrato de licença deverá ser averbado no INPI para que produza efeitos em relação a terceiros". Ou seja, o contrato não averbado somente produz efeitos entre as partes que o assinaram. ${ }^{287}$

Além do efeito erga omnes, a averbação ou registro de contratos de licença de uso de marcas pelo INPI produz os seguintes efeitos: (i) legitimar os pagamentos deles decorrentes para o exterior, observadas as disposições legais vigentes (Lei $\mathrm{n}^{\circ}$ 4.131/1962, Resolução no 3.844/2010 do Banco Central do Brasil); (ii) permitir, quando for o caso, a dedutibilidade fiscal, respeitadas as normas previstas na legislação específica (Lei $\mathrm{n}^{\circ}$ 4.131/1962, Lei no 8.383/1991, Decreto no 3.000/1999 e Portaria MF no 436/1958).

Outro efeito extraído da averbação pelo INPI do contrato de licença de uso de marca é a individualização da exclusividade do uso garantida ao licenciado, quando outorgada. Mediante a apresentação de um certificado de averbação do contrato, o licenciado poderá evitar que outros usuários não autorizados explorem a marca no território nacional. ${ }^{288}$

Os contratos de licença de uso de marca deverão dispor, por obviedade, sobre registros de marcas concedidos pelo INPI ou pedidos de registro ainda não analisados pelo órgão. Espelhando-se no Direito das Obrigações, a licença de uso de marca pode ser: (i)

\footnotetext{
${ }^{287}$ STJ. Terceira Turma. REsp n ${ }^{\circ}$ 606443/SP. Rel. Min. Castro Filho. Julgado em 05 de fevereiro de 2004. "PROPRIEDADE INDUSTRIAL - LICENÇA PARA USO DE MARCA - REGISTRO NO INPI - MEDIDA CAUTELAR - LIMINAR - DEFERIMENTO. O contrato de licença para uso de marca, para valer contra terceiros, precisa estar registrado no INPI. Assim, não ofende o artigo 140, $\$ 2^{\circ}$, da Lei $.^{\circ} .9 .279 / 96$, a decisão que defere liminar em autos de ação de busca e apreensão, proposta pelo licenciado, cujo contrato está devidamente registrado, contra o antigo usuário da marca, que não o registrou. Recurso especial não conhecido". No mesmo sentido, TINOCO SOARES, José Carlos. Lei de Patentes, Marcas e Direitos Conexos: Lei 9.279 - 14.05.1996. RT. São Paulo, 1997. p. 229.

${ }^{288}$ Há uma esfera particular de utilização desse argumento em casos de violação do direito de uso da marca que vem a ser o caso das importações paralelas. Nem sempre o argumento da existência de um licenciado exclusivo no território a fim de evitar a importação por terceiro predomina. Vide STJ. Quarta Turma. REsp nº 609047/SP. Rel. Min. Luis Felipe Salomão. Julgado em 20 de outubro de 2009.
} 
gratuita ou onerosa ${ }^{289}$; (ii) exclusiva ou não-exclusiva ${ }^{290}$; (iii) com prazo determinado ou indeterminado ${ }^{291}$; (iv) com limitação de território ou não. ${ }^{292}$

Um ponto interessante de ser comentado diz respeito à possibilidade do licenciado em agir em defesa da marca, sem prejuízo dos seus direitos, tudo de acordo com a novidade trazida pelo parágrafo único do artigo 140 da LPI. No entendimento de DANNEMANN, esse dispositivo veio a dirimir "[q]uaisquer controvérsias relativas à capacidade processual do licenciado de proceder em juízo, em defesa dos direitos do licenciante, tal como defesa da marca licenciada contra violação de terceiros, desde que contratualmente autorizado pelo licenciante no contrato, que precisará estar averbado no INPI para legitimar o licenciado nesse sentido". ${ }^{293}$

A LPI trouxe uma novidade no que tange à atuação de licenciados para a defesa da marca em questionamentos quanto ao uso efetivo da marca. O artigo 140, parágrafo $2^{\circ}$ da LPI diz que "Para efeito de validade de prova de uso, o contrato de licença não precisará estar averbado no INPI”. Isso significa que, em havendo licença expressa, mas não averbada pelo INPI ou até mesmo, licença tácita, o uso da marca por licenciados poderá ser levado em consideração aos fins de evitar a caducidade da marca licenciada.

\subsection{Direito de zelar pela integridade material e moral}

Haverá dedicação sobre esse tema no Capítulo VI do presente estudo, e portanto, aqui reserva-se comentar que a proteção à integridade material da marca e a reputação do seu titular consistem no principal eixo de proteção das marcas. O já

\footnotetext{
${ }^{289}$ Os contratos de licença de uso de marca, quando onerosos, só serão averbados pelo INPI se os objetos da licença forem registros de marca devidamente concedidos. Se as marcas forem meros pedidos sem análise e as partes disporem sobre a característica onerosa do contrato, o INPI até o averbará, mas com a ressalva quanto à impossibilidade do mesmo ser oneroso.

${ }^{290}$ A exclusividade da licença pode ser negociada entre as partes. A não-exclusividade da licença de uso da marca é possibilitada pela ubiquidade dos bens intangíveis.

${ }^{291}$ Quando não houver determinação de validade do contrato, o mesmo vigorará pelo tempo de validade do registro da marca licenciada.

${ }^{292}$ Se não houver limitação expressa de território, a licença de uso de marca valerá para todo o território nacional, de acordo com o artigo 129 da LPI.

${ }^{293}$ DANNEMANN. Op. cit. p. 281.
} 
mencionado artigo 130, inciso III da LPI concede ao titular de registro de marca ou pedido sem análise pelo INPI ${ }^{294}$ o direito de zelar pela sua integridade material ou reputação.

Inclusive, SCHECHTER já referendou essa posição. Apesar do enfoque na proteção de marcas arbitrárias e fantasiosas contra o aproveitamento parasitário, alguns princípios colocados pelo autor precisam ser levados em consideração para fins de proteção da integridade material da marca:

"(1) que o valor da marca moderna reside no seu poder de venda, (2) que o poder de venda depende, para o seu domínio psicológico sobre o público, não apenas sobre o mérito dos bens sobre os quais ela é usada, mas também sobre a sua própria unicidade e singularidade, (3) que tal unicidade ou singularidade padece ou prejudicada pelo seu uso em produtos relacionados ou não-relacionados, e (4) que o seu grau de proteção depende, por sua vez, da extensão a que, por meio de esforços ou engenhosidade de seu proprietário, é na verdade é único e diferente de outras marcas". ${ }^{295}$

No caso da proteção da integridade moral, entende-se pelo presente estudo que o legislador quis relacionar essa possibilidade à proteção da reputação do titular da marca, posto que afastado está, pelo menos até o presente momento, a hipótese de qualquer bem intelectual possuir reputação per se.

\footnotetext{
${ }^{294}$ TJSP. Ap. Cív. no 0165677-35.2007.8.26.0100. $6^{\text {a }}$ Câmara de Direito Privado. Relator(a): Francisco

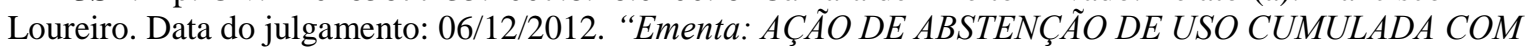
INDENIZAÇÃO. Ré que apresenta seus produtos com rótulo em imitação do rótulo do produto "H2OH!" de titularidade das autoras. Depósito do pedido de registro de marca que já á apto a ensejar a tutela do artigo 130, III da Lei $n^{\circ}$ 9.279/96. Rótulo do produto "Cachoeira" que, analisado em seu conjunto, permite concluir pela imitação da marca da autora, em exploração indevida do prestígio alheio. Perícia conclusiva no sentido da imitação. Prática de concorrência desleal da ré que, por meio da imitação da marca das autoras, promove desvio de clientela, já que atuam no mesmo mercado e comercializam o mesmo produto. Nítida remissão da embalagem da ré à marca líder de mercado, em manifesta prática de parasitismo. Vedação ao enriquecimento sem causa. Inviabilidade da indenização em face da não comprovação do dano sofrido na fase de conhecimento. Ação improcedente. Recurso parcialmente provido".

${ }^{295}$ SCHECHTER. Op. cit. pp. 830/831. Tradução livre do original: "(1) that the value of the modern trademark lies in its selling power; (2) that the selling power depends for its psycological hold upon the public, not merely upon the merit of the goods upon which it is used, but equally upon its own uniqueness and singularity; (3) that such uniqueness or singularity is vitiated or impaired by its use upon either related or non-related goods; and (4) that the degree of its protection depends in turn upon the extent to which, through the efforts or ingenuity of its owner, it is actually uniqe and different from other marks".
} 


\section{Capítulo V \\ O USO E O SISTEMA DE PROPRIEDADE INTELECTUAL}

\section{Considerações gerais}

O sistema de Propriedade Intelectual tem como uma das principais características a motivação de sua existência pelo uso dos bens intelectuais. O uso, assim, exerce papel fundamental na constante corrida desenvolvimentista das inovações, do consumo, da prevenção de doenças, das políticas públicas para o acesso a medicamentos etc., pois é esse instituto que permite às sociedades experimentarem os avanços dos mercados.

A criação é favorecida pelo incremento na facilidade de "publicação" trazida pelos meios de comunicação atuais, fazendo com que a criação, que dependia de uma “indústria cultural”, passa a aproximar-se do indivíduo que pode, com seus próprios meios, criar e tornar público (ou seja, "publicar") sua obra. ${ }^{296}$

Acaso não houvesse um sistema que regulasse os direitos sobre bens intelectuais, bem possível que o ato da cópia saísse vitorioso. De acordo com Cláudio BARBOSA, autores afirmam que copiar uma invenção de um terceiro custa consideravelmente menos do que o desenvolvimento de um novo produto, mesmo se considerado o custo de engenharia reversa inevitavelmente necessário para a cópia. Nesse sentido, existe um estímulo muito grande para a cópia e pouco incentivo para a produção. $^{297}$

A justificativa, portanto, da existência da propriedade intelectual é necessária para a consolidação de seu valor. Os argumentos clássicos para a justificação do sistema de propriedade intelectual, de acordo com Cláudio BARBOSA, são: (a) o direito pessoal que os criadores dos bens intelectuais teriam; (b) a recompensa que os criadores teriam pelos benefícios trazidos à sociedade; (c) a versão mais elaborada dos dois primeiros (ainda que

\footnotetext{
${ }^{296}$ BARBOSA, Cláudio, Op. cit. pp. 38/39.

${ }^{297}$ BARBOSA, Cláudio, Op. cit. p. 11. Nota 22. No mesmo sentido, BARBOSA, Denis. Proteção das marcas... Op. cit. p. 169: "O livre jogo de mercado é insuficiente para garantir que se crie e mantenha o fluxo de investimento em uma tecnologia ou um filme que requeira alto custo de desenvolvimento e seja sujeito a cópia fácil".
} 
não dependentes dos mesmos), na recompensa pela alocação de esforços e capital em criar um bem intelectual; e (d) a recompensa pela divulgação (publicação) da informação, permitindo que terceiros usufruam dessas obras intelectuais. ${ }^{298}$

Nota-se, apesar da necessidade de um sistema que regule os direitos de propriedade intelectual, que a intervenção estatal na concessão artificial de direitos de uso exclusivo merece cuidados, de modo a evitar injustiças na esfera privada dos direitos. Nessa linha de raciocínio, os comentários de Denis BARBOSA sobre a intervenção do INPI na diluição da distinção entre as marcas valem ser transcritos:

"A questão se resume, pois, em demonstrar que, ao dar o registro, o INPI invadiu propriedade pública, violou a res communis omnium (ou, no caso, o sermus communis, que é o mesmo no campo das palavras). A distinguibilidade é uma questão de grau, não de substância - há um ponto em que uma marca pode surgir na sensibilidade do público como distinta, separada, característica do que todo mundo já usa e pode usar em face do objeto simbolizado". ${ }^{299}$

Das muitas formas possíveis e estímulo ao investimento criativo, a história real das economias de mercado inclinou-se por um modelo específico: aquele que dá ao criador ou investidos um direito de uso exclusivo sobre a solução tecnológica, ou sobre a obra do espírito produzida. $^{300}$

Há um interesse social para que os investimentos em Propriedade Intelectual persistam, mesmo numa economia de mercado, e para isso, algum tipo de ação deve ser intentada para corrigir esta deficiência genética da criação intelectual. ${ }^{301}$ Assim é que a intervenção do Estado em contrapartida aos investimentos tecnológicos ocorre com o intuito de oferecer vantagens a particulares, como o direito exclusivo, o direito de exclusão de terceiros, percepção econômica pela exploração em contrapartida dos investimentos envidados pelos titulares. ${ }^{302}$

\footnotetext{
${ }^{298}$ BARBOSA, Cláudio, Op. cit. p. 49.

${ }^{299}$ BARBOSA, Denis Borges: Marca. A mais importante das propriedades intelectuais. Disponível em http://www.denisbarbosa.addr.com/104.doc. Acessado em 19 de julho de 2011.

${ }^{300}$ BARBOSA, Denis. Proteção das marcas. Op. cit. p. 167.

${ }^{301}$ BARBOSA, Denis. Proteção das marcas. Op. cit. p. 169/170.

${ }^{302}$ BARBOSA, Denis. Proteção das marcas. Op. cit. p. 192: “(A marca) significa, distinguindo certos valores na concorrência, diferenciando produtos e serviços, assegurando (quando registradas) um espaço de exclusão para o uso do signo, permitindo (aqui, como os demais objetos da propriedade intelectual) que o investimento na criação da imagem-de-marca retorne àquele que o promoveu, em vez de ser disperso pelo uso público, não rival e não exclusivo”. No mesmo sentido: SILVEIRA, Newton. Curso... Op. cit. p. 35: “ $O$
} 


\section{A lógica do sistema}

Um sistema é um conjunto de elementos interconectados, de modo a formar um todo organizado. ${ }^{303}$ A propriedade intelectual é um elo de uma importante corrente. Em pleno século XXI, a sociedade é interpretada como uma grande indústria de conhecimento. Outrora, em tempos de revolução industrial, a sociedade se via responsável pela produção de bens de consumo duráveis ou não, à luz das aplicações de conhecimentos alcançados por pesquisa e desenvolvimento.

No fundo, desde o século XIX, os conceitos do capitalismo não mudaram muito já que as pessoas são as mesmas, as necessidades são parecidas e os anseios aumentaram. Na verdade, o que mudou foi o conhecimento, que diante do avanço das tecnologias em todas as áreas de atividade, tem sido capaz de produzir produtos melhores e customizados aos anseios do século XXI. Segundo João Marcelo de Lima ASSAFIM, "[O] surgimento da tecnologia decorre, sempre, de uma reação sobre a natureza para adaptar o meio ao ser humano e se faz presente para suprir necessidades elementares (...)", ${ }^{304}$ Logo, o processo de geração de tecnologia consiste no motor que ajuda a unir os elementos do sistema de Propriedade Intelectual.

Com o avanço dos conceitos sobre pesquisa aplicada, inovação, P\&D, inovação tecnológica e outros ${ }^{305}$, é que " [a]s empresas estão conscientes da necessidade de agregar inteligência a seu produto investindo a longo prazo em pesquisa $e$ desenvolvimento. Por isso, os ativos intangíveis são amplamente reconhecidos como fator relevante de competitividade no mercado internacional". 306

As palavras acima de Kamil IDRIS, então diretor geral da OMPI, dão o tom sobre a importância da Propriedade Intelectual para o avanço da humanidade.

sistema de registro de marcas e concessão de patentes de invenção e modelos é um sistema formalista, que atende à necessidade de segurança e rapidez das relações comerciais”. E ainda, KUNTZ, Karin Grau. Op. cit. p. 13.

${ }^{303}$ Cf. http://pt.wikipedia.org/wiki/Sistema. Acessado em 29 de novembro de 2012.

${ }^{304}$ ASSAFIM, João Marcelo de Lima. A transferência de tecnologia no Brasil. Aspectos contratuais e concorrenciais da propriedade industrial. Rio de Janeiro: Lumen Juris, 2005. p. 17.

${ }^{305}$ ASSAFIM. Op. cit. p. 15.

${ }^{306}$ IDRIS, Kamil: A importância do uso de ativos de Propriedade Intelectual. In: RABPI v. 74, pp. 3/13, Rio de Janeiro: ABPI, jan/fev 2005. p. 3. 
Em uma visão econômica, Luciano Benetti TIMM, Renato CAOVILLA e Gustavo BRENDLER anotam que "a propriedade intelectual é considerada como o necessário incentivo para que alguém produza alguma coisa melhor ou que encontre um jeito melhor de produzir uma coisa antiga. Vale dizer, a propriedade intelectual apresenta-se como um mecanismo de incentivos para que os agentes econômicos engajemse em atividades de elevados custos e riscos de pesquisa e desenvolvimento (P\&D)", 307

É o verdadeiro estabelecimento de uma equação virtuosa composta por elementos diversos e todos muito importantes para o entendimento da lógica do sistema da Propriedade Intelectual. Nesse sentido, tem-se que:

$\mathrm{O}$ estudo gera o conhecimento $\rightarrow \mathrm{O}$ conhecimento gera a pesquisa $\rightarrow \mathrm{A}$ pesquisa gera a tecnologia $\rightarrow$ A tecnologia gera direitos temporários de uso exclusivo aos desenvolvedores $\rightarrow$ Os desenvolvedores são obrigados a descrever sua tecnologia, possibilitando que os concorrentes tenham acesso à informação $\rightarrow \mathrm{O}$ direito de uso exclusivo gera posição privilegiada ao desenvolvedor perante seus concorrentes $\rightarrow$ Os concorrentes tentam gerar produtos e serviços mais interessantes para os consumidores $\rightarrow$ Os consumidores acessam esses produtos e serviços utilizando-os em sua realidade pessoal $\rightarrow$ Esse acesso gera a competitividade entre os concorrentes $\rightarrow$ A expiração da validade do direito de uso exclusivo possibilita que a tecnologia seja revertida ao domínio público $\rightarrow$ Enquanto válido, o direito de uso exclusivo gera dividendos aos desenvolvedores de tecnologia $\rightarrow$ Os dividendos financiam estudos de novos produtos e serviços $\rightarrow$ Os estudos geram pesquisa $\rightarrow$ A pesquisa gera a tecnologia $\rightarrow$ etc.

Esse sistema é cultuado por aqueles que defendem a manutenção do sistema da Propriedade Intelectual, pois o mesmo é retroalimentado constantemente. Kamil IDRIS comenta que “(...) [a] recompensa que o titular recebe pelo seu investimento inicial em atividades de pesquisa e desenvolvimento resulta em benefícios para toda a sociedade: o investimento em atividades de pesquisa e desenvolvimento é contínuo, há intercâmbio de informações entre pesquisadores de áreas diferentes, surge uma demanda por pessoal capacitado, o que leva à disseminação de programas de treinamento. Consequentemente,

\footnotetext{
${ }^{307}$ TIMM, Luciano Benetti, CAOVILLA, Renato e BRENDLER, Gustavo. Op. cit. p. 1.
} 
percebe-se um importante crescimento de mão-de-obra especializada e de oferta de postos de trabalho". 308

Note-se que o sistema precisa manter sua sinergia ${ }^{309}$ e no caso específico da Propriedade Intelectual, o uso é o seu motor. Sem ele, as engrenagens das experiências humanas com as tecnologias emperram e pesquisa e desenvolvimento já não serão necessários. Do que adiantará o estudo e o acesso ao conhecimento sem aproveitamento dos frutos obtidos? Se a população não fizer uso dessas tecnologias, como os desenvolvedores buscarão por inovações que facilitem a solução das dificuldades deixadas pelos produtos e serviços ultrapassados?

\section{O uso da marca como obrigação do titular}

O objetivo de qualquer marca é seu efetivo uso perante o mercado e consumidores $^{310}$, cujo titular demonstra seu interesse ao ocupá-la, e pela lógica do sistema, não deve o mesmo retirá-la do mercado.

Apesar do contexto social e do enfoque materialista de estudo dos direitos reais, Orlando GOMES auxilia a sintetizar a necessidade de utilização dos bens intelectuais para a manutenção do círculo virtuoso do sistema quando traz passagem da Constituição Federal da República Federativa da Alemanha, de 1949: "[A] propriedade obriga. O uso da propriedade deve concorrer também para o bem da coletividade". 311

\footnotetext{
${ }^{308}$ IDRIS, Kamil. Op. cit. p. 5.

${ }^{309} \mathrm{Cf}$. http://pt.wikipedia.org/wiki/Sistema. "A boa integração dos elementos componentes do sistema é chamada sinergia, determinando que as transformações ocorridas em uma das partes influenciarão todas as outras. A alta sinergia de um sistema faz com que seja possível a este cumprir sua finalidade e atingir seu objetivo geral com eficiência; por outro lado se houver falta de sinergia, pode implicar em mau funcionamento do sistema, vindo a causar inclusive falha completa, morte, falência, pane, queda do sistema etc". Acessado em 29 de novembro de 2012.

${ }^{310}$ SILVEIRA, Newton. Curso... Op. cit. p. 30: "Tanto as marcas registradas quanto as patentes de qualquer categoria caducam se não exploradas pelo titular, cessionário ou legítimo licenciado". No mesmo sentido, SOARES, José Carlos Tinoco: Tratado da Propriedade Industrial. Marcas e Congêneres. Jurídica Brasileira. São Paulo, 2003. p. 1179: "É, sem quaisquer resquícios de dúvidas, a livre iniciativa. É a possibilidade legal que tem o interessado de obter para si uma marca que julga não se encontrar em uso efetivo, dentro dos limites do território nacional, cumprindo a sua finalidade de assinalar e distinguir os produtos, mercadorias ou serviços"..

${ }^{311}$ GOMES, Orlando. Direitos Reais. 18 ${ }^{\mathrm{a}}$ Edição. Forense, Rio de Janeiro, p. 111.
} 
Pelo próprio conceito jurídico de uso, a sua noção é intuitiva ${ }^{312}$ posto que usar é por em funcionamento, exercitar. Não usar é se omitir, calar-se, esconder-se. Pelo sistema, tal atitude é contrária aos seus fundamentos e deve ser evitada. Se e quando titulares intentarem registros de marca perante a repartição pública atribuída de poder de concessão de marca, deve ser utilizada por seu titular com o objetivo claro e cristalino de fazer com o sinal seja transmitido e comunicado ao público e ao mercado, fazendo nascer todas as relações jurídicas plenas de um sistema capitalista, ou seja, relações de consumo, concorrência etc.

Dentro do campo da Propriedade Intelectual, os autores afirmam que também há obrigatoriedade de uso da marca para justificar a lógica do sistema e para mantê-lo em movimento adequando-se às suas funções. GAMA CERQUEIRA afirma que "[O] princípio da obrigatoriedade do uso das marcas registradas funda-se na própria função que elas desempenham no campo da indústria e do comércio", 313

De acordo com Elisabeth FEKETE, a propriedade sobre marcas apresenta singularidade de o usus ser obrigatório e acrescenta afirmando que, se houver falta de uso, haverá abuso. ${ }^{314}$

De forma complementar, Newton SILVEIRA comenta que "[o] registro sem uso corresponde a mero monopólio garantido pelo Estado em consideração a uma expectativa de uso futuro próximo". ${ }^{315}$ Continua o autor orientando que "[E]nquanto não se inicia o uso da marca, seu proprietário pode exercer todas as ações que a lei lhe

\footnotetext{
${ }^{312}$ CORREA, José Antonio Faria: O conceito de uso de marca. In: RABPI v. 16. Rio de Janeiro, maio/junho de 1995. "Usar, no campo do direito de marcas, é projetar o sinal para o mundo, para que a marca, antes uma simples potencialidade, passe a exercer a função a que se destina".

${ }^{313}$ CERQUEIRA, Op. cit. vol. II tomo II. p. 158. No mesmo sentido, Pontes de MIRANDA comenta que "[A] obrigatoriedade do uso atende à função mesma das marcas de indústria e de comércio, que distinguem, marcando, o que se produz ou vende, ou que se produz e vende. Evita, por outro lado, a marca chamada de defensiva ou de reserva, ou de obstrução". MIRANDA, Op. cit. tomo XVII, p. 185. E BITTAR e BITTAR FILHO ensinam que "a par do pagamento da contribuição devida, cumpre ao titular usar efetivamente a marca registrada". Continua comentando que o uso da marca "[j] ustifica-se pela necessidade de evitar-se registros inúteis ou obstrutivos, que cerceiam a possibilidade de utilização por outros, dentro do regime imperante de liberdade de iniciativa e pela função que exercem as marcas na indústria e no comércio". BITTAR e BITTAR FILHO. Op. cit. p. 139.

${ }^{314}$ FEKETE. Op. cit. p. 131.

${ }^{315}$ SILVEIRA, Newton. Licença... Op. cit. p. 27.
} 
garante, mas o bem tutelado será apenas sua legítima expectativa de utilizar a marca com exclusividade". 316

De acordo com Afonso Celso, citado por GAMA CERQUEIRA ${ }^{317}$, “[a] marca é um acessório do comércio ou da indústria; e se estes não são exercidos, desaparece a sua razão de ser, pela impossibilidade da concorrência criminosa, que a lei procura impedir, por meio de garantias especiais".

Impactante é a frase de P.R. Tavares PAES quando disse que "[a] marca não é enfeite ou adorno. Deve ser usada" ${ }^{318}$. Quase um desabafo, o manifesto bem resume o porquê do nascimento das marcas no momento criativo do titular. A marca não é para ser possuída e guardada para si.

Vê-se pelo acima que o objeto a ser tutelado com a obrigatoriedade do uso da marca é o direito do consumidor de experimentar o produto ou serviço aposto com a marca, fazendo com que a marca continue se comunicando ao público e concorrentes de modo que o sistema continue a girar, como um todo. É a proteção do próprio mercado e da concorrência, no fim das contas.

Pelo até aqui exposto, o uso da marca parece ser um estorvo ou uma estratégia de exclusão ilegal e que, na prática, pouco serve para justificar sua existência. Pelo contrário, o uso da marca é dos institutos do direito sobre a res mais importantes, pois dele nascem verdadeiro feixe de direitos ao utente. A própria função social dos bens intelectuais pode ser justificada com o simples uso da marca, que no final das contas, impulsiona investimentos, empregos, consumo, fatores essenciais em uma economia de mercado.

\footnotetext{
${ }^{316}$ SILVEIRA, Newton. Licença... Op. cit. p. 38.

${ }^{317}$ CERQUEIRA. Tratado... Op. cit, vol. II tomo II, p. 158.

${ }^{318}$ PAES, P.R. Tavares: Nova Lei da Propriedade Industrial. Lei no 9.279 - 14.05.96. Anotações. Revista dos Tribunais. São Paulo, 1996. No mesmo sentido: TRF 2a Região, Apelação Cível 1999.51.01.005507-6, Segunda Turma Especializada, Rel. Des. Federal Liliane Roriz, julgado em 30/09/2008: “1. Aos direitos de propriedade e de exclusividade de uso sobre uma marca, atribuídos pelo registro no órgão marcário, corresponde um dever legal de uso da mesma, decorrente da função social da propriedade, ora estabelecida na Constituição Federal".
} 
O princípio da obrigatoriedade do uso da marca recebeu especial atenção de GAMA CERQUEIRA 319 quando anotou que "[U]ma vez que a pessoa beneficiada não se utiliza da marca registrada, a qual, por conseqüência, deixa de desempenhar a função para a qual foi criada e que justifica a proteção legal, desaparece a razão de ser das excepcionais garantias asseguradas pelo registro, o qual deve desaparecer, revertendo a marca para o domínio público". Mais adiante, o autor celebra a necessidade de uso da marca de modo a evitar as marcas defensivas ou de reserva ou de obstrução, objetivando a liberação dos sinais não utilizados para ocupação e registro por terceiros. Aqui, já nota-se a preocupação dos doutrinadores em evitar que o sistema atributivo de direito seja utilizado por titulares munidos da vontade principal de ocupar o mais extenso espaço da res nullius e evitar que concorrentes se apoderem de marcas consideradas interessantes.

Por lei, a obrigatoriedade da marca suporta-se com a consequência pelo não uso da mesma, o qual é investigado por concorrentes através do procedimento administrativo de caducidade administrado pelo INPI.

\subsection{O desuso da marca}

O artigo 143 da LPI ${ }^{320}$ estatui que o registro da marca é extinto por falta de seu uso efetivo por seu titular ou por qualquer pessoa por ele autorizado. Referido artigo concentra quase todos os institutos que devem ser estudados sobre a caducidade do registro de marca. Desde o legítimo interesse do requerente da caducidade, a intervenção do INPI na contenda pela análise da documentação comprobatória do uso ou da justificativa pelo desuso $^{321}$, e ainda o período de investigação previsto como as definições de prazo para o início e interrupção de seu uso.

\footnotetext{
${ }^{319}$ CERQUEIRA, Tratado... Op. cit., vol. II tomo II, p. 158.

${ }^{320}$ Art. 143 LPI: "Caducará o registro, a requerimento de qualquer pessoa com legítimo interesse se, decorridos 5 (cinco) anos da sua concessão, na data do requerimento: I - o uso da marca não tiver sido iniciado no Brasil; ou II - o uso da marca tiver sido interrompido por mais de 5 (cinco) anos consecutivos, ou se, no mesmo prazo, a marca tiver sido usada com modificação que implique alteração de seu caráter distintivo original, tal como constante do certificado de registro. $\$ 1^{\circ}$ Não ocorrerá caducidade se o titular justificar o desuso da marca por razões legítimas. $\S 2^{\circ}$ O titular será intimado para se manifestar no prazo de 60 (sessenta) dias, cabendo-lhe o ônus de provar o uso da marca ou justificar seu desuso por razões legítimas".

${ }^{321}$ TRF 2 2 Região. Apelação Civel 99.02.10249-2, Primeira Turma Especializada, Rel. Des. Federal Márcia Helena Nunes, Julgado em 25/01/2006: “- Conforme jurisprudência reiterada que vem desde o TFR $e$ adotada por este Tribunal, a proibição de importação de produtos que determinada marca visa a distinguir constitui motivo de suficiente força maior a evitar a caducidade do seu registro”. E ainda: TRF $2^{\mathbf{a}}$ Região, $\underline{\text { Apelação Cível n }{ }^{\circ} \text { 93.02.03064-4, Segunda Turma Especializada, Rel. Juiz Fed. Conv. França Neto, Julgado }}$
} 
O instituto da caducidade consiste em uma das formas de extinção do registro de uma marca, objetivando impedir que registros sejam mantidos em pleno vigor, embora sem uso efetivo, somente podendo ser evitada se o titular do registro provar a ocorrência de força maior. ${ }^{322}$

O que deve-se ter em mente é que a caducidade é o remédio para um sistema doente, ou seja, o registro sem utilização efetiva pode contribuir para a contaminação do sistema se e quando o questionamento da falta de uso da marca se der de forma leviana e desleal, como bem apontou TINOCO SOARES:

"Muito embora assim o seja, acreditamos que o simples preenchimento de formulário, acompanhado ou não de petição, sem a demonstração cabal do legítimo interesse, não deveria ter o menor acolhimento por parte do INPI. Não deveria porque se alguém pretende a caducidade do registro de uma marca é, sem quaisquer sombras de dúvida, porque está interessado na obtenção do registro de igual ou semelhante marca, para os mesmos ou semelhantes produtos ou serviços. (...) Muito mais salutar tem sido o procedimento do Departamento de Marcas dos Estados Unidos da América que impõe, periodicamente, a apresentação de provas concludentes de uso efetivo de uma marca. E, a despeito dessa exigência, não se pode negar que se trata do país que detém o maior número de marcas vigentes e em pleno uso". 323

O critério do legítimo interesse parece acertado já que qualquer postulação exige tal requisito como condição de validade do pleito. Sem o verdadeiro interesse demonstrado, o sistema fica a mercê de free riders que objetivam o locupletamento do sistema e indiretamente, o consumidor. É forçoso notar, inclusive, que a abertura da possibilidade de requerimento de caducidade por quaisquer pessoas traz insegurança jurídica ao sistema, que já passa por período difícil de enforcement, haja vista a proliferação do ilícito de bens intelectuais no comércio internacional, suplantando facilmente o tráfico internacional de drogas. ${ }^{324}$ Nesse sentido, é preciso assentir que a

em 26/04/2005: "2. A adoção pelo Governo brasileiro de política de comércio exterior que proíbe a importação dos produtos que a Autora, ora Apelante, pretende distinguir com a marca SPALDING, sob o registro $n^{\circ}$ 006.689.787, configura motivo de força maior impeditiva à extinção do registro marcário;"

${ }^{322}$ TRF 2 ${ }^{\mathbf{a}}$ Região. Apelação Cível 2004.51.01.534594-7, Relator Des. Federal Messod Azulay Neto. Julgado em 08/03/2010.

${ }^{323}$ TINOCO SOARES. Tratado... Op. cit. pp. 1225/1226:

${ }^{324}$ NAÍM, Moisés: Ilícito. $O$ ataque da pirataria, da lavagem de dinheiro e do tráfico à economia global. Jorge Zahar Editor. Rio de Janeiro, 2006. p. 20: “Em 1998, o então diretor do Fundo Monetário 
exigência do legítimo interesse nos requerimentos de caducidade precisa ser demonstrado para ser aceito pelo INPI.

A natureza do fato que constitui uso de marca tem sido pouco ou nada discutido no Brasil. O tribunal europeu já foi solicitado a se manifestar a respeito do uso de marca em links patrocinados em sites de buscas. O assunto em si não guarda relação com o presente estudo, mas permite-se citar os julgados europeus apenas para demonstrar que existem usos e usos de marca. O tribunal europeu definiu nas ações C-236/08, C-237/08 e C-238/08 325 , o significado de uso de marca no comércio.

Em resumo, os casos concentravam-se em saber se o uso de marcas em links patrocinados pelo GOOGLE era considerado uso no comércio ou não. De acordo com os julgados, referido uso não reunia os requisitos estabelecidos pela Diretiva Européia para configuração de uso no comércio. Nas decisões, verificou-se que o GOOGLE, por não ser concorrente do anunciante e do titular prejudicado com o link patrocinado, não alcançava o consumidor com o uso tipificado. Esse ponto foi crucial para afastar a punibilidade dos sites de buscas dessa prática na internet.

$\mathrm{Na}$ decisão mais recente a respeito da natureza do uso de marca em links patrocinados, o Google saiu vitorioso mais uma vez, pelo menos no que diz respeito à intenção do site de confundir o consumidor. Em Rosetta Stone Ltd. v. Google, Inc., 2012 WL 1155143 (4th Cir. April 9, 2012), o Tribunal de Apelação do $4^{\circ}$ Circuito dos Estados Unidos entendeu que o uso de marca da autora como palavra-chave para link patrocinado de concorrente não criou confusão junto aos usuários. Levando-se em consideração 3 (três) dos 9 (nove) fatores de "probabilidade de confusão", quais sejam: (a) A intenção do

Internacional, Michel Camdessus, estimou o fluxo global de dinheiro sujo em torno de $2 \%$ a $5 \%$ da economia global, um número que classificou como 'além da imaginação'. No entanto, estimativas mais recentes colocam os fluxos de lavagem de dinheiro próximos a $10 \%$ do PIB global".

${ }^{325}$ Casos europeus C-236/08, C-237/08 e C-238/08 podem ser encontrados em http://eurlex.europa.eu/LexUriServ/LexUriServ.do?uri=CELEX:62008J0236:EN:HTML. "Com efeito, do ponto de vista do anunciante, a seleção da palavra-chave idêntica à marca tem por objeto e por efeito a exibição de um link publicitário para o sítio no qual propõe para venda os seus produtos ou serviços. Uma vez que o sinal selecionado como palavra-chave é o meio utilizado para provocar essa exibição publicitária, é incontestável que o anunciante faz um uso desse sinal no contexto das suas atividades comerciais, e não no domínio privado. Embora resulte destes elementos que o prestador do serviço de referenciamento opera «na vida comercial» quando permite aos anunciantes selecionar sinais idênticos a marcas, como palavras-chave, armazena estes sinais e exibe os anúncios dos seus clientes a partir destes, não resulta de tais elementos, no entanto, que esse prestador faça ele próprio um «uso» destes sinais na acepção dos artigos $5 .^{\circ}$ da Diretiva 89/104 e 9. 'do Regulamento n. 40/94’”. 
Google, (b) a confusão real e (c) a sofisticação do consumidor. A corte americana entendeu que o Google, como um site de busca, não tem objetivo de confundir o usuário. Ainda, a decisão levou em consideração a sofisticação da sociedade americana, que foi considerada capaz de avaliar as diferentes origens conforme sua natureza e seu valor.

A jurisprudência brasileira tem decidido no sentido diverso. ${ }^{326}$ Sem uma análise mais detida sobre o que significa uso no comércio, o uso de marcas registradas de terceiros em links patrocinados de concorrentes tem sido interpretado como infração à marca registrada.

Uma questão interessante que não se pode deixar de comentar se refere a natureza da decisão constitutiva negativa de extinção do registro de marca. ${ }^{327}$ Diferentemente das patentes e dos desenhos industriais, a marca extinta é considerada res nullius, pois retorna ao domínio público e pode ser ocupada por quem quer que seja, inclusive o próprio titular que a abandonou. Já as patentes e desenhos industriais extintos se tornam res communis omnium e não podem ser adquiridos já que carecem de novidade, requisito essencial para o impulsão da mola do sistema de Propriedade Intelectual.

A LPI impõe que o uso da marca deve ser iniciado em até 05 (cinco) anos após a concessão, que se exija uso efetivo como exigido após o referido prazo inicial. Ou seja, basta que a marca tenha tido um primeiro uso durante o primeiro qüinqüênio de concessão para presumir a intenção do titular de ocupá-la definitivamente. Qualquer exigência maior do que esta parece descabida e rígida, se houver a interpretação de que esse período inicial seja a chance oferecida aos empresários de experimentar o mercado em que o novo registro está se inserindo.

Outro capítulo interessante a comentar é a questão do uso efetivo da marca, que consiste no uso consistente e sério de acordo com a atividade designada pelo registro

\footnotetext{
${ }^{326}$ TJSP. Ap. Cív. n ${ }^{\circ}$ 990.10.127612-7. Rel. Des. Enio Zuliani. $4^{\text {a }}$ Câmara de Direito Privado. Julgamento: 23/09/2010. TJSP - Agravo de Instrumento ${ }^{\circ}$ 597.513-4/6-00. Des Relator José Carlos Ferreira Alves. $7^{\text {a }}$ Câmara de Direito Privado. Julgamento: 04/03/2009. TJRJ. Ap. Cív.1 no 0147301-07.2004.8.19.0001 (2008.001.60797). Rel. Des. Mario Assis Goncalves. - Terceira Câmara Cível. Julgamento: 07/04/2009.

${ }^{327}$ Importante frisar que a decisão de extinção do registro de marca, seja por expiração do prazo de vigência ou por renúncia, gera efeitos ex nunc posto que se difere das decisões de nulidade de registro cujo efeito retroage à data de depósito da marca, de acordo com o artigo 167 da Lei. É que o abandono do registro da marca deixa imaculada a sua vigência, já a nulidade ceifa a proteção sobre a mesma já que nula de pleno direito, desde o momento em que foi apresentada ao INPI.
} 
caducando. Assim, não parece justo exigir de um estaleiro marítimo a montagem de 20 (vinte) navios por mês para fins de comprovação do uso da marca. Ao contrário, parece justo se exigir a venda de 20 camisetas por mês para fins de comprovação do uso de uma marca de confecção. O que se quer dizer é que a natureza do produto ou serviço influencia para a análise do uso efetivo da marca. E o examinador de marcas do INPI precisa estar atento a esse detalhe que pode influenciá-lo a manter ou extinguir uma marca por falta de uso.

A caducidade $\operatorname{parcial}^{328}$ cumpre com a destinação do princípio da especialidade $^{329}$, sendo que a determinação das classes de produtos e serviços espelhadas através da Classificação de Nice, é mera ferramenta administrativa à disposição do INPI. No passado, não foi assim. ${ }^{330} \mathrm{O}$ instituto da caducidade parcial é novidade da LPI, promulgada em 1996, e vai de encontro ao atual cenário mundial de inovação tecnológica.

Aos olhos do free rider, o depósito de marca idêntica ${ }^{331}$ ao registro caducando pode significar um meio de burlar o sistema. Todavia, a prática de dualidade de marcas é proibida no Brasil, de acordo com o artigo 124, inciso XX da LPI. A dualidade de marcas

\footnotetext{
${ }^{328}$ Art. 144 LPI. "O uso da marca deverá compreender produtos ou serviços constantes do certificado, sob pena de caducar parcialmente o registro em relação aos não semelhantes ou afins daqueles para os quais a marca foi comprovadamente usada".

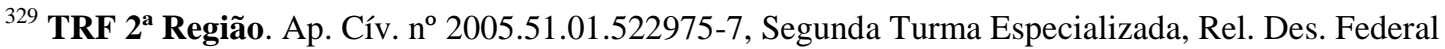
Liliana Roriz, Julgado em 17/02/2009: "3. Mediante um exame comparativo da marca em questão ("AS ANDORINHAS BRASILEIRAS”) com aquela aposta nas notas fiscais mencionadas, é possível vislumbrar que se trata efetivamente do mesmo signo. $O$ mesmo se verifica em relação aos demais documentos (Conhecimentos de Transportes Rodoviários de Cargas, Contratos de publicidade em vários veículos e comunicações em geral), nos quais se verifica a aposição da marca em tela de forma individualizada, demonstrando o uso efetivo da marca em seus empreendimentos negociais. Ocorre que, os documentos colacionados aos autos demonstram tão-somente a aplicação do signo relacionada ao segmento mercadológico de "transporte de carga, armazenagem e embalagem de mercadorias em geral" (38.20), restando não demonstrada documentalmente a utilização na classe 38.30, relacionada a "serviços de transporte de passageiros, viagem e turismo”. 4. Não estando o uso do signo compreendido em ambas as classes para a qual obteve registro, mas, tão-somente em uma delas, resta plenamente incidente sobre a hipótese a figura da caducidade parcial, prevista no art. 144 da LPI”.

${ }^{330}$ CERQUEIRA, Op. cit. Vol. II Tomo II. p. 164: "Tratando-se de marca registrada para distinguir mais de um produto ou artigo, não é necessário o seu uso em todos os produtos incluídos no registro para evitar a declaração de caducidade. Desde que a marca seja usada efetivamente para distinguir um desses produtos, o objetivo da lei fica satisfeito". No mesmo sentido: Pontes de MIRANDA, Op. cit. Tomo XVII. p. 185: “Se a marca registrada para distinguir dois ou mais produtos ou serviços, basta o uso em algum ou alguns deles. Idem, se há dois ou mais registros para produtos congêneres ou afins".

${ }^{331}$ Para haver identidade entre as marcas, é preciso que o pedido mais novo constitua uma reprodução da marca caducando e designe os mesmos produtos ou serviços do referido registro.
} 
proíbe o acúmulo de marcas idênticas, que apesar de não se destinarem ao uso efetivo, por uma cadeia de registros sucessivos, terminariam por evitar a caducidade. ${ }^{332}$

\section{O uso da marca como faculdade do titular}

Como preceitua o artigo 129 da LPI, a propriedade da marca se adquire pelo registro validamente expedido garantindo direito de uso exclusivo da marca em todo território nacional. Está bem observado que, em que pese a possibilidade de terceiros fiscalizarem o uso da marca pelo titular, este só o faz se lhe aprouver.

É bem verdade que a caducidade é a ferramenta instituída para fomentar o uso das marcas, evitando-se a formação de portfólios de marcas de reserva ${ }^{333}$ e entraves desnecessários de acesso às marcas por terceiros interessados.

Entretanto, não pode-se olvidar a esvaziar o feixe de direitos garantidos ao titular de um registro de marca. Como já exposto anteriormente, GAMA CERQUEIRA define que a marca é um sinal distintivo aposto facultativamente a produtos ou serviços. ${ }^{334}$

O artigo 143 da LPI garante ao titular o direito de começar a utilizar a marca em um prazo de 05 (cinco) anos contados da concessão do registro pelo INPI. Logo, se assim o desejar, a marca não será utilizada. E mais, se não quiser utilizá-la mesmo após esse prazo e em não havendo interessados na obtenção do registro para si, o registro restará mantido em vigor, mas o titular ficará sempre sujeito à fiscalização de terceiros interessados.

\footnotetext{
${ }^{332}$ BARBOSA, Denis. Proteção das marcas... Op. cit. p. 337.

${ }^{333}$ CERQUEIRA. Tratado... Op. cit. Vol. II Tomo II p. 159.

${ }^{334}$ CERQUEIRA, Tratado. Op. cit. Vol. I, p. 253.
} 


\section{Capítulo VI \\ O USO E A INTEGRIDADE DA MARCA}

\section{Breves linhas sobre o tema}

Com o intuito de interpretar as marcas como bens intelectuais passíveis de apropriação exclusiva e de gerarem efeitos quanto à sua integridade material e moral, é necessário analisar as definições de bens propostas pelo Direito Romano.

Como já comentado anteriormente, mas sendo importante repisar, as coisas (res) eram divididas coisas em comércio (res in commercio) e fora do comércio (res extra commercio). A res in commercio pode ser apropriada por privados, e a res extra commercio, não. As coisas fora do comércio são divididas entre as coisas de uso comum (res communis omnium), necessárias para o uso do povo e pertencentes ao domínio comum; e a res publicae pertencentes aos entens públicos, mas devotados ao domínio comum. Dentre a res in commercio, encontram-se as res nullius, que não pertencem a ninguém mas são apropriáveis por entes privados; e a res alii, coisas apropriáveis que já pertencem a entes privados.

O direito marcário considera res communis omnium os signos genéricos, os necessários, os de uso comum, assim como os signos descritivos, razão pela qual não são registráveis como marca de acordo com a $\mathrm{LPI}^{335}$, salvo se revestidos de suficiente cunho distintivo. $^{336}$

Para a questão em análise, a distintividade das marcas é ponto nevral, pois tal requisito determina se e quando um sinal nasce distintivo ou não; se no decorrer de sua

\footnotetext{
${ }^{335}$ Art. 124 LPI. Não são registráveis como marca: VI - sinal de caráter genérico, necessário, comum, vulgar ou simplesmente descritivo, quando tiver relação com o produto ou serviço a distinguir, ou aquele empregado comumente para designar uma característica do produto ou serviço, quanto à natureza, nacionalidade, peso, valor, qualidade e época de produção ou de prestação do serviço, salvo quando revestidos de suficiente forma distintiva.

${ }^{336}$ SILVEIRA. Curso... Op. cit. p. 65: O autor comenta que "[A] tutela da marca se fixa em sua eficácia distintiva, não devendo abarcar os elementos genéricos, não suscetíveis de tutela. Por isso se diz que é requisito da marca sua novidade relativa. De qualquer forma, o que importa é o elemento característico da marca e o âmbito dentro do qual se protege a função distintiva". A distintividade de uma marca é fator essencial de diferenciação no mercado. Sob o ponto de vista da informação, sinais descritivos ou necessários não comunicam e por isso, não se diferenciam dos demais.
} 
vida, alcança distintividade com o uso ou perde a distintividade deixando de ser marca para se tornar res communis omnium. Esses pensamentos se voltam ao estudo dos fenômenos lingüísticos aplicados às marcas e estudados pela Semiótica, a ciência das palavras, pois demonstram as implicações que o uso da marca impõe à sua integridade material.

A Semiótica, apesar de importante para a análise da integridade material das marcas, merece tom introdutório para o presente estudo, pois apesar de explicar os fenômenos lingüísticos dinâmicos que uma marca pode experimentar em sua vida de utilização perante o mercado e os consumidores, tal ciência se preocupa com o estudo do processo em si, e não com as consequiências emanadas através da utilização desses sinais.

Umberto ECO trouxe lições relevantes para a análise da Semiótica ao estudar os signos. Segundo o autor, "[u]m signo é a correlação de uma forma significate com uma (ou com uma hierarquia de) unidade que definimos como significado. Nesse sentido, o signo é sempre semioticamente autônomo em relação aos objetos a que se pode ser referido",337. Continua o autor explicando que "[s]ignos são sinais cujo processo comunicativo envolve um significado a ser interpretado pela mente humana", 338

Destacam-se na definição acima três elementos para sua compreensão: o significante (o próprio signo); o significado (o que se quer dizer com o signo); e a referência (objeto a que se refere o signo).

Na mesma linha, SAUSSURE ensina que "[O] signo é aquilo que une o significado (a imagem acústica da coisa designada, que se forma no cérebro quando pronunciada, ainda que silenciosamente) ao significante (a palavra ou conceito arbitrário usado para designar algo)". 339

PEIRCE traz a mesma noção da definição de Umberto ECO ao definir que a expressão Semiótica possui os mesmos três elementos, quando escreveu que "[O] signo envolve três elementos: o significante, seu significado (objeto) e o interpretante, que

\footnotetext{
${ }^{337}$ ECO, Umberto. O signo. $6^{\text {a }}$ Ed. Lisboa: Presença, s.d., p. 50.

${ }^{338}$ ECO. Op. cit. p. 13.

${ }^{339}$ SAUSSURE, Ferdinand de. Curso de lingüística geral. $4^{\text {a }}$ edição. São Paulo: Cultrix, 1972. pp. 80/81.
} 
consiste nas várias potencialidades de compreensão que o signo pode gerar na mente do destinatário da mensagem (o intérprete)". 340

Barton BEEBE ${ }^{341}$, citando Paul PERRON, afirma que Semiótica é "um domínio de investigação que explora a natureza e a função de sinais, bem como os sistemas e processos de significação subjacente, representação, expressão, $e$ comunicação".

Cláudio BARBOSA, preocupado com o estudo da Propriedade Intelectual como informação, demonstrou entendimento de que os símbolos permitem a transmissão de informações do fornecedor ou do produto ao consumidor. ${ }^{342}$

Denis BARBOSA, em sua análise semiótica sobre as marcas, ensina que o signo seria, funcionalmente, a representação de algo, em face de uma pessoa determinada; a representação presume um sistema, e o liame entre signo e objeto se define por oposição - define-se o signo pelo que ele não é, pelo encadeamento estrutural de diferenças. ${ }^{343}$

Analisando a ideia de Semiótica oferecida por PEIRCE, a distintividade que legitima ou denega o registro parte da mesma noção de motivação. Os signos que expressam, na linguagem comum, a própria coisa ou um elemento dela, não são registráveis. São registráveis, embora com restrições, os signos que mantêm uma relação icônica (descritiva ou evocativa) com a coisa; livremente protegidos, com máxima extensão, os signos arbitrários ${ }^{344}$. E continua Denis BARBOSA propondo que o instituto do valor é importante para a leitura referencial às marcas, asseverando que o valor é a relação entre signos, significante e significados, no exercício da estrutura, em delimitações recíprocas e articulações, no que se constitui na langue. ${ }^{345}$

\footnotetext{
${ }^{340}$ PEIRCE, Charles Sanders: Semiótica. $3^{\text {a }}$ edição. São Paulo: Perspectiva, 2005.

${ }^{341}$ BEEBE, Barton. A semiotic analysis of the Trademark Law. In: UCLA Law Review. Univ. of California, v. 51. Los Angeles: Univ. of California, 2004. Págs. 621 e seguintes. Tradução livre do original: “[a] domain of investigation that explores the nature and function of signs as well as the systems and processes underlying signification, expression, representation, and communication"

${ }^{342}$ BARBOSA, Cláudio, Op. cit. p. 151.

${ }^{343}$ BARBOSA, Denis. Proteção das marcas... Op. cit. p. 43.

${ }^{344}$ BARBOSA, Denis. Proteção das marcas... Op. cit. p. 45.

${ }^{345}$ BARBOSA, Denis. Proteção das marcas... Op. cit. p. 46.
} 
Lélio SCHMIDT entende que a visão proposta por PEIRCE possui o mérito de ilustrar a relevância não somente da marca em relação ao seu objeto, mas também “[à] percepção que ela desperta nos indivíduos". Continua o autor afirmando que essa percepção é muito importante para o estudo das marcas pois embasa a análise da repressão ideológica de marcas; o estudo do processo lingüístico denominado secondary meaning ${ }^{346}$; e ainda o processo lingüístico da perda da distintividade das marcas pela vulgarização, ou seja, quando o uso da marca compele a mesma a significar o gênero do produto ou serviço que ela designava. ${ }^{347}$

Numa análise semiológica aplicada à concorrência, a marca identificaria os produtos ou serviços na concorrência (referente), em face do elemento perceptível pelos sentidos, sinal ou nome (o significante), e igualmente, em face do significado a origem dos produtos ou serviços - como percebida pelo consumidor. ${ }^{348}$

Denis BARBOSA continua informando que a função de distinção também teria expressão ótima no ideal de unicidade - "a marca expressaria um intenso e inconfundível lugar na concorrência, com os atributos da bi-univocidade entre referente $e$ significante". 349

Por essas últimas linhas, vê-se que a Semiótica está diretamente relacionada à integridade material da marca, mas ela apenas estuda o relacionamento das marcas (significante), o seu significado e a sua referência perante a sociedade. Importante notar que a marca, quando utilizada, sofre as conseqüências que não são explicadas pela Semiótica. Pelo que se pôde apresentar, a Semiótica é importante para a análise da variação da integridade material da marca em seus processos lingüísticos.

\footnotetext{
${ }^{346}$ SCHMIDT. Marcas em semiótica... Op. cit. p. 08: “[q] uando o consumidor consegue identificar um produto ou serviço a despeito de sua marca consistir numa palavra comum, que em razão do contexto de seu uso se descola de seu sentido lexical e passa a desempenhar papel marcário, como ocorre com a marca GREMIO.

${ }^{347}$ SCHMIDT. Marcas em semiótica... Op. cit. pp. 7 e 8.

${ }^{348}$ BARBOSA, Denis. Proteção das marcas... Op. cit. p. 46.

${ }^{349}$ BARBOSA, Denis. Proteção das marcas... Op. cit. p. 53. Continua o autor informando que " $[a]$ marca designa não exatamente o produto, mas a origem do produto (ou serviço). As vicissitudes desta origem contaminam a marca em sua eficácia jurídica. Assim, o efeito simbólico se exerce num contexto igualmente simbólico, através de mecanismos de deslocamento metonímico ou gravitação metafórica por acavalgamento ou dispersão, etc". Op. cit. p. 60.
} 
Revela-se no presente estudo que as noções de distintividade de uma marca influenciam a capacidade da mesma de se comunicar com o público e de diferenciar os concorrentes uns dos outros. Em um processo de vulgarização, por exemplo, a marca deixa de ser distintiva e passa a ser um elemento de uso comum, possível de ser utilizada por qualquer um. No ponto de vista proposto, a integridade material da marca vulgarizada é inexistente.

Especificamente sobre a integridade material das marcas, a noção de distintividade é relevante, já que ela constitui um dos básicos requisitos que uma marca precisa cumprir para ser considerada registrável e apropriável exclusivamente por entes privados.

É relevante manter estreita relação com o instituto da distintividade pois há muito a doutrina e jurisprudência brasileiras vêm utilizando-o para demonstrar, com a mesma palavra, dois aspectos diferentes. A marca tanto precisa ser distintiva em si mesma - distintividade intrínseca ${ }^{350}$ - como deve ser distintiva quando comparada a outras marcas - distintividade extrínseca. ${ }^{351}$

Assim, com o intuito de evitar confusões entre dois institutos tão diferentes, prefere-se utilizar duas expressões distintas, alinhando-se com a percepção demonstrada por GAMA CERQUEIRA que já apontava a dupla funcionalidade do termo em relação às marcas ao afirmar que "[d]estinando-se a distinguir produtos idênticos ou semelhantes, a marca não pode deixar de ser distinta, sob duplo aspecto: ser característica em sí mesma, possuir cunho próprio e distinguir-se das outras marcas já empregadas". 352

Sob o ponto de vista legislativo, o termo distintividade encontra mais afinidade com a capacidade de uma marca distinguir seus produtos ou serviços. Ou seja, se o sinal simplesmente descreve o produto ou serviço, se significa vulgarmente o mesmo, ou tiver relação imediata com as características intrínsecas dos produtos/serviços, o mesmo não pode distinguir-se das demais marcas no mercado. Seria injusta e contraditória à própria

\footnotetext{
${ }^{350}$ Art. 124, VI LPI.

${ }^{351}$ Art. 124, XIX LPI. Vide nota 53.

${ }^{352}$ GAMA CERQUEIRA. Op. cit. Vol. I. p. 256. No mesmo sentido, BARBOSA, Denis. Proteção das marcas... Op. cit. p. 09. O autor comenta que a marca precisa cumprir o duplo requisito da distintividade. E no mesmo sentido, MORO. Op. cit. p. 114.
} 
filosofia do sistema, a aquisição de um direito de uso exclusivo de um sinal que descreve uma característica necessária ao mercado para comercializar tal produto ou serviço. Em vista dessa relação íntima com o sentido, é preferível manter-se o termo distintividade para designar a necessária distintividade intrínseca de uma marca.

GAMA CERQUEIRA acertou ao utilizar a palavra distinta na passagem acima pois é exatamente isso que a marca precisa ser em relação às demais de modo a diferenciar um fabricante ou comerciante de seus concorrentes. Daí é que o artigo 124, inciso XIX da LPI dispõe sobre a necessidade de uma marca ser distinta das outras já registradas em seu campo de atividade, com os fins de ser considerada registrável. Assim é que prefere-se a expressão distinção para caracterizar a distintividade extrínseca das marcas.

A integridade moral do titular da marca é objeto de estudo no presente capítulo sob o ponto de vista da utilização mal-intencionada por concorrentes, que com o simples objetivo de atacar a reputação da marca de terceiros, faz uso de expedientes ilícitos combatidos pela repressão à concorrência desleal, objeto dos artigos 195 e seguintes da LPI. Por outro lado, não pode-se deixar de comentar as utilizações de marcas que são permitidas a terceiros, como a publicidade comparativa, o fair use objeto do artigo 132 da LPI e àqueles que desejem expressar seus comentários a respeito de produtos marcados de acordo, ou meramente porque desejam se expressar. Tais utilizações podem ser consideradas permitidas por mais que atentem à integridade moral das marcas comentadas ou comparadas.

Portanto, ver-se-á nas linhas subseqüentes que a marca pode sofrer revés de acordo com a forma de sua utilização perante o público, tanto sobre o ponto de vista de sua integridade material, quando os fenômenos lingüísticos aplicam seus resultados, quanto sob o ponto de vista de sua integridade moral.

\section{A integridade moral do titular}

A construção do título desse item é meramente um identificador das agruras que os titulares de marca experimentam com a utilização desautorizada de seus signos. A marca, em si, não sofre, mas simboliza os resultados sentidos pelo agente econômico, titular do seu direito de exploração comercial. Nesse sentido, Newton SILVEIRA comenta 
que, presumindo que a marca não possua individualidade própria, afirmar que a mesma tenha reputação não terá sentido, e ensina que a integridade moral recai sobre o empresário ou ao estabelecimento produtor. ${ }^{353}$

No desenvolvimento da análise do artigo 130, inciso III da LPI, é interessante notar que o titular da marca ou depositante tem o direito de zelar por sua integridade material ou reputação. O pronome possessivo "sua" oferece dupla interpretação sobre o sujeito do zelo mencionado pelo referido inciso. "Sua" pode se referir ao titular da marca ou à própria marca em si. Para os efeitos do presente trabalho, quer-se crer que "sua" faz remissão à marca quando o texto remete à integridade material e no que tange à reputação, refere-se ao titular da marca.

\subsection{Denegrimento}

Não parece haver dúvida de que, em havendo uso indevido de marca por terceiros, todos perdem: o titular do direito de uso exclusivo, o consumidor e a concorrência. O titular porque perde poder de venda de sua marca e muitas vezes, vê a sua reputação manchada pelas agruras que o infrator faz o consumidor passar. O consumidor, como já introduzido, sofre porque adquire produto interpretando ser o originalmente procurado, e muitas vezes, sofre ainda mais quando adquire contrafação. E a concorrência porque perde a oportunidade de competir de igual para igual e às vezes, deixa de investir em qualidade em virtude da "comparação por baixo".

Assim é que, em havendo ilícito no uso da marca de outrem, corre-se o risco de desestruturar uma cadeia de atores importantes do sistema de Propriedade Intelectual.

SCHECHTER, citando o caso Powell v. Birmingham Vinegar Brewery Co., Ltd. 13 Rep. Cas. 235, 250 (1896), deixa claro que, independentemente do conhecimento pelo público sobre o titular da marca, se esta é usada indevidamente, seu titular sofre infração à sua reputação. No referido caso, a Côrte americana decidiu que "[P]essoas podem ser enganadas e podem confundir uma classe de produtos por outra, embora elas não saibam os nomes dos fabricantes de cada um. Uma pessoa cujo nome não é

\footnotetext{
${ }^{353}$ SILVEIRA, Newton. Licença... Op. cit. p. 3.
} 
conhecido, mas cuja marca é imitada, é tanto prejudicado em seu comércio, como se seu nome fosse conhecido, bem como a sua marca. Sua marca, como usada por ele, construiu uma reputação a seus produtos. Seu comércio depende muito de tal reputação. Sua marca vende seus produtos". 354

A pirataria ${ }^{355}$ consiste em um câncer que ilustra todos os elementos acima. Não à toa que o STJ já emitiu decisões nesse exato sentido, ao interpretar que "[P]roduto falsificado cuja qualidade, em comparação com o original, não pôde ser aferida pelo Tribunal de Justiça. Violação da marca que atinge a identidade do fornecedor. Direito de personalidade das pessoas jurídicas. Danos morais reconhecidos". ${ }^{356}$ Nesse julgado, o STJ, ao reconhecer a possibilidade de denegrimento à reputação da pessoa jurídica e por desdobramento, de sofrimento de dano moral, entendeu que "[o] consumidor é enganado $e$ vê subtraída, de forma ardil, sua faculdade de escolha. O consumidor não consegue perceber quem lhe fornece o produto e, como consequência, também o fabricante não pode ser identificado por boa parte de seu público alvo. Assim, a contrafação é verdadeira usurpação de parte da identidade do fabricante”.

Ou seja, tanto o titular do uso exclusivo de marca quanto o consumidor sofrem com a prática ilícita de infração de marca. O denegrimento sofrido pela pessoa jurídica, titular de registro de marca, é latente e assim, o crime de "pirataria" contribui negativamente para a integridade moral da empresa.

Em situação menos parecida, a prática comercial de importação paralela ${ }^{357}$ também pode contribuir para o denegrimento da reputação de empresa quando o

\footnotetext{
${ }^{354}$ SCHECHTER. Op. cit. p. 815. Tradução livre do original: "Persons may be misled and may mistake one class of goods for another, although they do not know the names of the makers of either. A person whose name is not known, but whose mark is imitated, is just as much injured in his trade as if his name was known as well as his mark. His mark, as used by him, has given a reputation to his goods. His trade depends greatly on such reputation. His mark sells his goods".

${ }^{355}$ O termo "pirataria" era aplicado principalmente a indivíduos apátridas, que tomavam posse de mercadorias transportadas em alto mar pelo Estado ou por companhias por ele garantidas. Copiar, reproduzir ou vender produtos alheios sem respeitar os direitos e a vontade dos criadores e donos originais. Essa é basicamente a definição de pirataria, prática ilegal que vem sendo muito difundida e discutida ultimamente, mas que já incomoda a sociedade há séculos. Algumas das grandes invenções da humanidade tiveram a paternidade disputada, e mesmo copiada, por várias pessoas. Todas sempre competindo para obter o reconhecimento legal, intelectual e financeiro sobre as obras.

${ }^{356}$ STJ, $3^{\text {a }}$ Turma, REsp 1032014/RS, Rel. Min. Nancy Andrighi, publ. DJe 04/06/2009.

${ }^{357}$ Há muito a ser escrito sobre o capítulo das importações paralelas e o princípio da exaustão na área de marcas, porém esse não é o objetivo do presente estudo. Em resumo, uma parte da doutrina e da
} 
importador paralelo não auxilia na manutenção do bom relacionamento da marca importada com os consumidores. É o caso, independentemente do posicionamento jurisprudencial, de importações realizadas sem o conhecimento do titular do direito de uso exclusivo e de um distribuidor exclusivo para um determinado território que venham a prejudicar a reputação do titular da marca com a possível diferença de qualidade do produto importado ou inadequação do mesmo ao mercado local. Nesse caso estrito, o titular da marca que investe no relacionamento com seus clientes oferecendo assistência técnica dos produtos vendidos e garantia de troca em casos de defeitos insolúveis, perde assim como o consumidor.

Em caso parecido, o STJ coibiu a importação paralela quando esta tenha ocorrido sem a anuência do titular da marca no exterior ${ }^{358}$, não ocorrendo portanto o consentimento que exclui a ilicitude da comercialização do produto, objeto do já citado artigo 132, inciso III da LPI. ${ }^{359}$ Nessa ação judicial, é bem verdade, que existiu um tempero auxiliar para a aplicação do princípio da exaustão nacional. $\mathrm{O}$ importador paralelo recondicionava produtos sem a anuência do titular da marca ou do seu distribuidor no Brasil. Nessa linha, o STJ entendeu que o importador paralelo causou confusão ao consumidor, que espera o mesmo padrão de qualidade do referido produto, independentemente da origem fornecedora do mesmo. ${ }^{360}$

No que tange às importações paralelas e à integridade moral dos titulares de marcas, entende-se que tal prática comercial será lícita quando não houver denegrimento das empresas titulares de direitos de uso exclusivo de marcas.

\footnotetext{
jurisprudência nacionais entende que há consentimento do titular quando da primeira venda do produto desde a sua origem, definindo o princípio da exaustão internacional. Do outro lado, estão aqueles que entendem que a primeira venda tenha que ocorrer no território nacional, com o consentimento do titular do direito de uso exclusivo no país, definindo o princípio da exaustão nacional. Muitas críticas existem para ambos os princípios e existem interpretações jurisprudenciais nos dois sentidos. Exemplos: A favor do princípio da exaustão nacional: TJRS, Sexta Câmara Cível, Agravo 70002659688, decidido em $1^{\circ}$ de agosto de 2001. A favor do princípio da exaustão internacional: TJSP, $2^{\text {a }}$ Câmara Reservada de Direito Empresarial, Apelação $\mathrm{n}^{\circ}$ 0027772-86.2010.8.26.0001, decidido em 07 de agosto de 2012.

${ }^{358}$ STJ. Quarta Turma, Recurso Especial 1207952/AM, Rel. Min. Luis Felipe Salomão, publ. DJe 01/02/2012: “As importações paralelas lícitas são contratos firmados com o titular da marca no exterior, ou com quem tem o consentimento deste para comercializar o produto. Tendo o Tribunal de origem apurado não haver autorização, pela titular da marca, para a importação dos produtos, o artigo 132, inciso III, da Lei 9.279/96, não socorre a recorrente".

359 Art. 132, inciso III da LPI. Vide nota 54.

${ }^{360}$ STJ. REsp 1207952/AM. "Tolerar que se possa recondicionar produtos, sem submissão ao controle e aos padrões adotados pelo titular da marca - que também comercializa o produto no mercado -, significaria admitir a inequívoca confusão ocasionada ao consumidor que, ao adquirir produto da marca, espera obter bem de consumo que atenda a determinado padrão de qualidade e confiabilidade que associa ao signo”.
} 


\section{A integridade da marca}

Muito se tem falado sobre a defesa da marca tanto sob o ponto de vista do contencioso administrativo quanto do judicial. Não há dúvidas de que ambos os palcos vêm evoluindo no que tange ao estudo dos princípios aplicáveis, limites de proteção, vantagens e desvantagens de certos sinais distintivos em função da área de atividade envolvida, etc.

Entretanto, após a novidade trazida pela LPI quanto à possibilidade concedida aos titulares de registros ou pedidos sem análise pelo INPI de defenderem suas marcas com vistas a zelar por sua integridade material e reputação ${ }^{361}$, um novo capítulo sobre a proteção das marcas descortinou-se, e assim novos pensamentos sobre tais institutos começaram a fluir tanto da doutrina quanto da jurisprudência.

Essa novidade tem sido interpretada pela doutrina e pela jurisprudência como a possibilidade de proteção das marcas contra diluição. Todavia, esse entendimento tem se mostrado limitado e obtuso. Pouco provável que o legislador nacional tenha tido a preocupação de proteger somente as marcas famosas, como ocorre nos Estados Unidos, contra o uso indevido por não-concorrentes, o aproveitamento parasitário. ${ }^{362}$

Logo, a visão sobre a integridade da marca que se propõe é ampla e é direcionada à análise tanto da distintividade intrínseca (distintividade stricto sensu objeto do artigo 124, inciso VI da LPI) como da distintividade extrínseca (distinção objeto do artigo 124, inciso XIX da LPI).

\footnotetext{
${ }^{361}$ Art. 130, inciso III LPI: Vide nota 12.

${ }^{362}$ SCHECHTER. Op. cit. p. 825. "Piratas de marcas estão cada vez mais sutis e refinados. Eles procedem prudentemente, por sugestão e aproximação, em vez de reprodução direta e exata de produtos de suas vítimas e marcas. A história dos litígios de marca importantes nos últimos anos mostra que o uso de marcas semelhantes em bens não-concorrentes é talvez o normal em vez de excepcional nos casos de violação". Tradução livre do original: "Trademark pirates are growing more subtle and refined. They proceed circumspectly, by suggestion and approximation, rather than by direct and exact duplication of their victims wares and marks. The history of important trademark litigation within recent years shows that the use of similar marks on non-competing goods is perhaps the normal rather than exceptional case of infringement".
} 


\subsection{A integridade material}

De acordo com o que se propõe pelo presente estudo, a integridade material de uma marca tem de ver com a inteireza das suas funções distintivas intrínseca e extrínseca: o corpo de proteção da marca. Se esse corpo for maculado, seja pelo próprio titular ou por terceiros, parte da capacidade distintiva da marca erode, fazendo com que seu poder de impedir usos indevidos também esmoreça.

Assim, separaram-se as noções de integridade moral (reputação) e integridade material das marcas. Esta, como comentado, está diretamente relacionada com a distintividade, intrínseca e extrínseca, que um signo distintivo possui.

Além disso, outro fator empreende efeitos na distintividade da marca que é o uso da mesma no mercado. Uso e distintividade estarão sempre reunidos pois um pode ser causa e consequência do outro. Por exemplo, com o uso de um elemento de uso comum por certo período de tempo e o alcance de certo renome no mercado, alcança-se proteção exclusiva sobre o mesmo. Ou seja, caso não fosse pelo processo linguístico de mutação de um sinal descritivo, necessário, vulgar ou comum em um sinal distintivo de um ente privado, não entenderíamos o processo de secondary meaning, onde a distintividade é a consequência do uso do elemento comum.

Interessante exemplificar também o caminho inverso, qual seja, o processo de vulgarização de um sinal plenamente distintivo. $\mathrm{O}$ uso da marca pelo titular ou por terceiros no sentido de designar o próprio gênero do produto pela sua marca faz com que a integridade distintiva da marca pereça, vertendo a mesma ao domínio comum. Assim, temse o uso como causa da perda da distintividade da marca. É o exemplo das ex-marcas FORMICA $^{363}$ e CELLOPHANE. ${ }^{364}$

De forma mais sutil, a integridade distintiva da marca deixa de ser singular em processos como o da diluição e do desgaste. Ambos os processos representam o esfarelamento da integridade material da marca, o que não significa o total perdimento de

\footnotetext{
${ }^{363}$ STF. 1 ${ }^{\text {a }}$ Turma, Recurso Extraordinário 107.892-8, Rel. Min. Rafael Mayer, publ. DJU 27.06.1986. ${ }^{364}$ Cour de Cassation. Julgado em 11/05/1966. In: Revue Internationale de la Propriété Industrielle et Artistique, n. 68, p. 75/79, Juin 1967. Também em LANDES e POSNER. Op.cit. p. 169.
} 
seu poder distintivo. A diluição da marca famosa se dá pelo seu uso indevido por nãoconcorrentes, seguindo a teoria americana. E o desgaste da distinção se dá com o deferimento de pedidos de marca semelhantes que guardam distância distintiva suficiente para se evitar risco de confusão pelo consumidor que pela convivência pacífica de marcas parecidas, já estaria acostumado e atento às pequenas diferenças entre os sinais distintivos.

E é nesse ambiente que se propõe o estudo dos processos linguísticos das marcas impulsionados pelo seu uso.

\subsubsection{A distintividade}

Para que uma palavra, expressão ou figura seja registrada como marca no Brasil, o artigo 122 da LPI dispõe que ela precisa ser um (i) sinal distintivo (ii) visualmente perceptível e (iii) não compreendido nas proibições legais do artigo 124 da mesma Lei.

Um princípio elementar para a análise do que pode ser apropriado como marca, na análise de Denis BARBOSA, é o duplo requisito de distintividade. Considera-se diferencialmente distintivo o signo que se distingue dos demais já apropriados por terceiros ou, mais precisamente, o que pode ser apropriado pelo titular, sem infringir direito de terceiros. Considera-se absolutamente distintivo o signo que, em relação ao nome comumente usado (em domínio comum) para o objeto designado, tenha tal autonomia que permita apropriação singular. ${ }^{365}$

A distintividade é a capacidade de uma marca em distinguir seus produtos ou serviços, sem que isso represente prejuízo a terceiros, incluindo os concorrentes, no que tange à utilização de elementos comuns, necessários, vulgares ou genéricos para o cumprimento de seus atos empresariais. Ou seja, o registro de marca composta por elemento de uso comum fere o direito dos concorrentes, já que constitui-se em res communis omnium.

\footnotetext{
${ }^{365}$ BARBOSA, Denis. Proteção das marcas... Op. cit. p. 09. No presente trabalho, como já comentado, prefere-se o uso do termo distintividade aplicado à noção da distintividade intrínseca da marca. E usa-se a expressão poder de distinção para simbolizar o caráter diferenciador da marca em relação às demais existentes no mercado.
} 
De acordo com Pontes de Miranda "[O] que não distingue não se pode considerar marca",366. No mesmo sentido, CORREA afirma que “[o]s sinais, quando genéricos ou descritivos e, portanto, sem aptidão para servirem de marca de produto ou serviço, são o que, dentro da categorização semiológica trinária de Peirce (1931) se convencionou denominar símbolos, que, diversamente do que se passa com os ícones, na visão do autor, são ontologicamente neutros, independentes do conteúdo semântico a que se ligam. Por isso, são chamados de sinais distintivos, no sentido clássico". 367

Continua CORREA ensinando que a marca é um conteúdo arbitrário, não genérico em relação a produtos ou serviços que deve denotar no mundo empresarial, apresentada sob diversos canais sensoriais e fixada em suportes físicos, visuais, traduzido sob diversos sistemas de apreensão visual. ${ }^{368}$ Em última análise, o que se ampara é o conceito, expresso em sistemas inteligíveis à sociedade.

A função, pois, da marca, é permitir ao público, em uma estrutura econômica de concorrência, distinguir os produtos ou serviços de determinado fabricante, comerciante ou prestador de serviços, de outros que com eles dividem o mercado e buscam a conquista do consumidor. Um sinal genérico, comum, vulgar, de uso comum, necessário ou simplesmente descritivo seria imprestável para essa função, pois não é apto para diferenciar um produto ou serviço de outros, sendo franqueado a todos os que competem no mercado. Admitir-lhe o registro em nome de um competidor privaria os demais de um instrumento de comunicação de domínio público, constituindo res communis omnium.

J. X. Carvalho de MENDONÇA definiu a denominação necessária como " $[a]$ que se prende à própria natureza do produto designado; é a que se acha a ele incorporada, constituindo o seu próprio nome; denominação vulgar, usual, é aquela que, não tendo sido originariamente o verdadeiro nome do produto, acabou por ser consagrada pelo uso, entrando na linguagem corrente como seu nome". 369

\footnotetext{
${ }^{366}$ MIRANDA, Pontes. Tratado... Op. cit. p. 196.

${ }^{367}$ CORREA, Jose Antônio Faria. Sinais não registráveis. In: SANTOS, Manoel J. Pereira dos e JABUR, Wilson Pinheiro (Orgs.). Sinais Distintivos e Tutela Judicial e Administrativa. Série GVLaw. São Paulo: Saraiva, 2007. p. 211.

${ }^{368}$ CORREA. Sinais não registráveis... Op. Cit. p. 216.

${ }^{369}$ MENDONÇA, J. X. Carvalho de. Tratado de Direito Commercial, v. III, T. I, Rio de Janeiro: Russel, 2003, p. 267.
} 
Continua o autor a afirmar que "[u]ma e outra se acham no domínio público; a ninguém é lícito tornar qualquer delas objeto de direito exclusivo. Apropriar-se da denominação necessária ou vulgar do produto ou da mercadoria, para compor a marca desse produto ou dessa mercadoria, importaria em monopolizar não somente a sua fabricação ou a sua venda, como a dos produtos similares e idênticos de outros fabricantes ou comerciantes", 370

Segundo Denis BARBOSA, “[é] distintivo, objetivamente considerado, o que tem características próprias, o que não significa, de forma a desempenhar a função marcária que lhe é própria", 371

SCHMIDT faz o mesmo tipo de comentário ao afirmar que "[C]omo a proteção não recai sobre a marca em si, enquanto sinal isoladamente considerado, mas sobre o seu uso para identificar determinado produto ou serviço, nada impede que a marca seja formada por palavras comuns e usuais, integrantes do vocabulário. A marca PANELA pode ser registrada para identificar serviços de autoescola. O que não se admite (ressalvado o caso de aquisição de distintividade através do uso) é seu registro para utensílios domésticos, pois o artigo 124, inciso VI, da Lei 9279/96 a tanto se opõe”. ${ }^{372}$

Maitê MORO enumera diversas nomenclaturas para a distintividade: capacidade distintiva, poder distintivo, eficácia distintiva, caráter distintivo, cunho próprio e esclarece que todas elas indicam a capacidade de distinguir do sinal utilizado em relação aos demais produtos e serviços do mesmo gênero. Completa a autora que a distintividade refere-se ao sinal em si e não ao sinal em relação aos demais. ${ }^{373} \mathrm{E}$ apoia-se em MATHÉLY, quando afirma que o sinal para ter capacidade distintiva "[o] sinal deve ser arbitrário em relação ao objeto designado."374

\footnotetext{
${ }^{370}$ MENDONÇA. Op. cit. p. 267.

${ }^{371}$ BARBOSA, Denis Borges. Uma Introdução... p. 806.

${ }^{372}$ SCHMIDT. Marcas em semiótica... Op. cit. p. 48.

${ }^{373}$ MORO. Op. cit. p. 114.

${ }^{374}$ MATHÉLY, Paul. Op. cit. p. 59. Tradução livre do original: "[l]e signe doit être arbitraire à l'érgard de l'objet designe".
} 
MORO também entende que a apreciação da distintividade no Brasil faz parte do exame do pedido de registro de marca com fins à concessão de um direito exclusivo. ${ }^{375}$ Diferentemente do que ocorre nos Estados Unidos, onde a distintividade adquirida também é capaz de constituir direito de uso exclusivo ${ }^{376}$, o sinal precisa nascer distintivo em relação aos produtos ou serviços que assinala no Brasil, sob pena de indeferimento do pleito, de acordo com o artigo 124, VI da LPI.

ASCARELLI, sobre a capacidade distintiva escreveu que "[a] marca como um sinal distintivo precisa ter, como já observado, capacidade distintiva e eficácia distintiva do produto: é nessa eficácia distintiva, nessa contribuição à individualização (a nomenclatura já dissemos em lições anteriores, sentindo que não estamos nos referindo apenas às denominações) de realidade e com referência a bens e produtos que se encontra a criação intelectual, que, então, constitui o bem imaterial protegido". 377

No mesmo sentido, MATHÉLY expressa que "[o] signo não pode constituir uma marca válida se não for distintivo". ${ }^{378}$ Já para CARNELUTTI, "[é] absurda a tutela jurídica de uma situação material quando ela é per se ineficaz a atingir o escopo que deveria, mediante a tutela, ser garantido". E continua o autor anotando que "[S]e a marca é comum... não é mais marca, porque não distingue". 379

Em uma interpretação prática da distinividade de palavras estrangeiras, CARVALHO DE MENDONÇA citou o caso da marca HISTOGENOL, composta por duas palavras gregas que significam "tecidos" e "eu produzo". Foi considerada neologismo, e o registro foi permitido. ${ }^{380}$. No mesmo sentido, pode-se citar o caso POMAROLA, a qual, apesar de significar molho de tomate em Italiano, impediu o uso de

\footnotetext{
${ }^{375}$ MORO. Op. cit. p. 122.

${ }^{376}$ Nos Estados Unidos, a marca para ser registrável precisa ser distintiva originalmente (inherently distinctive) ou possuir distintividade adquirida ao longo de seu uso (secondary meaning).

${ }^{377}$ ASCARELLI. Teoria... Op. cit. p. 311. Tradução livre do original: "quale segno distintivo il marchio deve avere, come già notato, efficacia distintiva e efficacia distintiva del prodotto: è in questa efficacia distintiva, in questo apporto allá individuazione (alla nomenclatura abbiamo detto nelle precedenti lezioni, avvertendo che non ci riferivamo esclusivamente a denominazioni) della realtà e com riferimento a merci e prodotti che risiede la creazione intellectuelle, che poi costituisce il bene imateriale tutelato".

${ }^{378}$ MATHÉLY. Op. cit. p. 59. Tradução livre do original: "[l]e signe ne peut constituer une marque valable que s'il est distinctif".

${ }^{379}$ CARNELUTTI. Op. cit. pp. 46/47.

${ }^{380}$ MENDONÇA. Op. cit. p. 256.
} 
POMARETTI, cujo uso foi considerado indevido tendo em vista possibilidade de aproveitamento. $^{381}$

De modo a aplicar os ensinamentos acima, podemos citar como exemplo a palavra LIMÃO para designar o comércio de frutas. Tal palavra é essencial para uma parcela da concorrência para a consecução de suas atividades e por isso, ela não é considerada res nullius para o comércio de frutas, e sim res communis omnium.

Do lado oposto, pode-se colocar a palavra APPLE para designar produtos de informática. Tais elementos nada têm de relacionado com essa área de atividade, garantindo distintividade à marca APPLE e pleno direito de uso exclusivo e de exclusão de terceiros ao titular que a detiver.

A doutrina majoritária tenta quantificar os graus de distintividade dos sinais que determinam a integridade distintiva das marcas e o poder de exclusão de terceiros garantido ao seus titulares.

As marcas arbitrárias são compostas por elementos que possuem significado próprio, mas nada tem a ver com a área de atividade especificada. Exemplos são as marcas ROLEX, VISA, NIKE, APPLE, MOÇA. As marcas fantasiosas são compostas por elementos criados por seus titulares e que não possuem significado próprio. Logo, nada têm a ver com a área de atividade especificada. Alguns exemplos de marcas fantasiosas/inventadas são KODAK, XEROX, LYCRA.

As marcas arbitrárias e fantasiosas são consideradas marcas fortes pela doutrina e pela jurisprudência.

\footnotetext{
${ }^{381}$ TSJP. Ap. Cív. 71.568-1, RTJESP 124/231. Vide também RJTJESP 129/219 e JTJ 161/156: POMAROLA VS. POMARETTI - Impossibilidade do uso desta - Não há como considerar, em óbice para essa solução, que possa ter havido o aproveitamento, como marca, de uma expressão alienígena, de dialeto regional italiano, como o significado de molho de tomate, se, de todo o modo, não era utilizada comumente no Brasil, com esse sentido. Não é invulgar o uso de palavras estrangeiras, mesmo quando indicativas do gênero do produto a ser designado, se não usadas ou conhecidas, com o mesmo sentido, no País. Sendo exemplo expressivo disto o emprego da expressão GELATO, como marca distintiva de sorvete, muito embora signifique exatamente sorvete, em língua italiana".
} 
Já as marcas sugestivas ou evocativas são formadas por elementos que possuem significado relacionado de alguma forma à área de atividade especificada, mas não há imediatismo na referida relação, sendo necessária formação de processo intelectual para o alcance do significado da marca. Muitas marcas sugestivas são consideradas doutrinariamente como marcas fracas. $^{382}$ Ex: JAGUAR, BOMBRIL, GAROTO, SPOLETO. ${ }^{383}$

SCHMIDT entende que as marcas MINASGAS, KAZA, FOTÓTICA, BOMBRIL e ALÔ BEBÊ são evocativas. ${ }^{384}$ Apesar desse entendimento, a justaposição de elementos de uso comum não desvia a capacidade descritiva do elemento formado. No momento da leitura das marcas acima, o interpretante consegue identificar automática e imediatamente o produto ou serviço designado pelas marcas. Dessa forma, existindo imediatismo nessa interpretação, há descrição de alguma característica do produto ou serviço.

Haveria concordância com o posicionamento de SCHMIDT se o exemplo fosse a marca KIBON, que apesar de sua notoriedade, não entrega imediatamente ao interpretante o produto ou serviço que designa.

Lélio continua comentando que as marcas CASA DO PÃO DE QUEIJO e TELEFÔNICA também são marcas evocativas. No mesmo sentido do parágrafo anterior, ambas as marcas denunciam imediatamente os produtos ou serviços designados, independentemente do fenômeno do secondary meaning, aplicado a essas marcas famosas.

\footnotetext{
${ }^{382}$ Muitos autores chamam as marcas pouco distintivas de fracas, tais como José Antonio Faria Correa (Marcas fracas ma non tropo - In RABPI v. 10, p. 32), Couto Gonçalves (Direito de Marcas, p. 75), Gérard Dassas (L'enlargissement de la protection des marques em droit français, allemand et international. Paris: Libraries Techniques, 1976, p. 171/172), Albert Chavanne e Jean-Jacques Burst (Droit de la propriété industrielle.Paris: Dalloz, 1976, \& 593 e 606, p. 270 e 278), Tullio Ascarelli (Teoria de la concorrenza e dei beni immateriali. $3^{\text {a }}$ edição. Milão: Giuffrè, 1960, p. 443), J. J. Thomas MCCARTHY. McCarthy's desk encyclopedia of intellectual property. Washington: BNA, 1991 (1a edição) e 2000 (2a edição, 4a reimpressão).

${ }^{383}$ BARBOSA, Denis. Proteção das marcas... Op. cit. p. 78: "Spoleto evoca a Itália e seu gênero gastronômico; para os apaixonados pela Úmbria, evoca um charme singular de uma cidade fora de rota de grande público, mas preciosa em sua beleza, coziness e umas trufas negras locais memoráveis. O público, ou parte dele, construirá mais facilmente a correlação, ainda que com perda de de notatividade e de biunivocidade".

${ }^{384}$ SCHMIDT. Marcas em semiótica... Op. cit. p. 76.
} 
Entretanto, o autor acerta ao afirmar que as marcas COPPERTONE (tom de cobre) e PALMOLIVE (palma de oliva) são evocativas. De fato, ambas não apresentam de forma imediata seus produtos e por isso, merecem ser tratadas como marcas sugestivas.

As marcas descritivas ${ }^{385}$, na verdade, não são marcas, pois descrevem características, qualidades, natureza, origem ou até o próprio produto ou serviço. Exemplos que podem ser citados são NATURA, AMERICAN AIRLINES e ZERO CAL.

Apesar de não serem consideradas marcas, por serem desprovidas de distintividade, marcas descritivas são escolhidas por boa parcela dos fabricantes e comerciantes pois economizam gastos publicitários já que descortinam imediatamente o próprio produto ou serviço. Por outro lado, os titulares nada podem fazer caso concorrentes escolham as mesmas palavras para designar seus produtos, incitando assim a convivência das mesmas. ${ }^{386}$

Essa construção doutrinária muito repetida em nossa jurisprudência tem sido determinante na interpretação do grau de confusão quando da comparação entre sinais de origens diferentes. Uma conclusão pode ser alcançada com o exposto até aqui: Quanto maior a distintividade, maior será o grau de proteção da marca.

Na realidade, não há diferença no registro de marcas fracas ou fortes, uma vez que todas as marcas registradas devem preencher os requisitos impostos para o registro. A diferença prática no âmbito de proteção e na maior ou menor vulnerabilidade não influencia o registro da marca, mas terá repercussão na maior ou menor exclusividade de uso de seu titular. ${ }^{387}$ Em que pese esse entendimento, a capacidade distintiva do sinal influencia sobremaneira a sua integridade e sua força para evitar a diminuição do seu poder distintivo. Dessa forma, não há que se negar que a distintividade de um sinal é fator preponderante na manutenção da integridade das marcas.

\footnotetext{
${ }^{385}$ MATHÉLY, Paul. Op. cit. p. 68. "Os signos descritivos se referem à característica essencial do produto, e não a uma ou outra particularidade efêmera, aleatória ou secundária".

${ }^{386}$ SCHMIDT. Marcas em semiótica... Op. cit. p. 76/77.

${ }^{387}$ MORO. Op. cit. p. 126.
} 


\subsubsection{As "apostilas" aplicadas pelo INPI}

A distintividade constitui um dos requisitos de registrabilidade de um sinal como marca, e significa a capacidade que um elemento nominativo, figurativo ou tridimensional ou o conjunto dos mesmos possui para designar um produto ou serviço. Nesse sentido, a marca composta por elementos capazes de cumprir com a sua principal função, ou seja, distinguir o objeto por ela marcado, individualizando-o de outros do mesmo gênero, natureza ou espécie, pode ser considerada distintiva.

O ordenamento jurídico nacional, desde o Código de Propriedade Industrial de 1945, institui limitações quanto à integridade distintiva dos sinais em relação aos produtos ou serviços a serem designados pelos mesmos. A LPI resumiu em seu artigo 124, inciso VI, as limitações previstas no antigo Código de Propriedade Industrial de 1971 (artigo 65, itens $6^{388}$ e $20^{389}$ da Lei $n^{\circ} 5.772 / 71$ ), quanto ao registro de sinais compostos por elementos genéricos, comuns, vulgares ou que guardassem relação direta com o produto ou serviço que as marcas objetivassem a distinguir.

Em que pese a existência de limites legais quanto à distintividade de um sinal, não existem procedimentos formais de análise da distintividade de um elemento a fim de amparar o exame de marcas pelo INPI. Não existindo regras instituídas, os examinadores de marcas do INPI se apóiam na subjetividade para a identificação da capacidade distintiva de um elemento, concedendo-o exclusivamente ao requerente ou não. ${ }^{390}$

Assim, caso o elemento seja considerado distintivo, o mesmo é concedido exclusivamente ao requerente. Caso contrário, o mesmo não é extraído do domínio público. Seguindo essa diretriz, segue abaixo os possíveis resultados de exames de marcas

\footnotetext{
${ }^{388}$ Artigo 65, item 6 CPI. "Não é registrável como marca: denominação genérica ou sua representação gráfica, expressão empregada comumente para designar gênero, espécie, natureza, nacionalidade, destino, peso, valor e qualidade.

${ }^{389}$ Artigo 65, item 20 CPI. Não é registrável como marca: nome, denominação, sinal, figura, sigla ou símbolo de uso necessário, comum ou vulgar, quando tiver relação com o produto, mercadoria ou serviço a distinguir, salvo quando se revestirem de suficiente forma distintiva.

${ }^{390}$ Nesse sentido, BARBOSA, Denis. Proteção das marcas... Op. cit. p. 127: “Tal apostilamento, fundado em costume administrativo do INPI, quando da concessão dos registros de marcas, mas sem autorização legal, tem como propósito restringir os novos direitos ao limite da possibilidade do domínio público baseado no princípio da proporcionalidade, ou seja, o apostilamento deve ressaltar o máximo possível a pretensão do depositante em face do domínio comum".
} 
compostas por elementos distintivos per se ou irregistráveis de acordo com o artigo 124, inciso VI da LPI:

(i) Se a marca é composta por elementos considerados distintivos per se, o registro é concedido, conferindo exclusividade temporária do sinal para designar os produtos/serviços solicitados pelo titular da marca;

(ii) Se a marca é composta por elementos considerados não-distintivos, a marca é indeferida por falta de distintividade;

(iii) Se a marca é composta por elementos distintivos e não-distintivos, a marca é deferida, mas a exclusividade é limitada aos elementos identificados como distintivos pelos Examinadores;

(iv) Se a marca é composta por elementos não-distintivos, mas a aglutinação de tais elementos confere um conjunto capaz de distinguir os produtos/serviços, a mesma é deferida com o limite de exclusividade apenas para aquele conjunto solicitado.

Com o intuito de diferenciar os sinais distintivos dos não-distintivos, nas hipóteses (iii) e (iv) acima, o INPI impõe ressalvas à exclusividade dos referidos elementos, dependendo de sua constituição. As ressalvas, também chamadas de apostilas, utilizadas pelo INPI, variam em sua concepção, mas alguns exemplos podem ser citados:
(a) "Sem direito ao uso exclusivo do(s) elemento $(s)$.........................";
(b) "Sem direito ao uso exclusivo da expressão ...............................";
(c) "Sem direito ao uso exclusivo do elemento nominativo";
(d) "Sem direito ao uso exclusivo do elemento figurativo"; e
(e) "No conjunto".

Desde a criação do INPI, em 1970, os examinadores vêm concedendo marcas compostas por elementos irregistráveis, fazendo ressalvas, isto é, especificando a não exclusividade dos mesmos. Em uma busca informal na base de dados do órgão, verificamos que na primeira década de sua existência, o INPI deferiu mais de 600 (seiscentas) marcas com essas ressalvas (apostilas). 
Inconformados com esse tipo de decisão administrativa, os titulares vêm tentando reformar as decisões do INPI junto ao Judiciário ${ }^{391}$.

O instituto da ressalva ou apostila sempre foi alvo de críticas dos usuários do sistema de marcas brasileiro, devido à subjetividade da análise da distintividade dos elementos que compõem as marcas. Em vista da falta de um regramento instituído e do entendimento difuso dos examinadores de marcas do INPI, é notória a oscilação histórica de entendimentos sobre o estabelecimento de apostilas.

O fato de que determinado registro tenha ou não sido deferido com uma apostila, não reflete necessariamente o entendimento de mérito do INPI quanto à extensão da integridade material (exclusividade) assegurada, pois entendimentos podem ter oscilado em função da mudança de formalidades (épocas com apostila e outras sem) adotadas pelo órgão.

Portanto, não é incomum encontrarmos desiguais análises para o mesmo elemento em diferentes pedidos de registro de marca examinados pelo INPI, causando uma desequilibrada jurisprudência de exames de marcas, e diminuindo a proteção conferida a sinais originalmente interpretados como distintivos frente às decisões de apostilamento do mesmo em pedidos de registro posteriores.

De fato, o titular de marca composta por elementos considerados irregistráveis não será, em tese, capaz de impedir terceiros de utilizarem os mesmos elementos para designar produtos ou serviços idênticos ou semelhantes, tendo em vista que os referidos elementos de uso comum pertencem ao domínio comum e não podem ser adquiridos exclusivamente por qualquer titular.

Todavia, ao INPI não é permitido diluir ou violar uma marca registrada, enfraquecendo sua integridade material (distintividade), valor econômico e proteção

${ }^{391}$ TFR 4a Região. Apelação Cível 79.262/1983; TRF 2a Região. Apelação Cível 99.02.23288-4/02 - Rio de Janeiro. $6^{\mathrm{a}}$ Turma; TRF 2 ${ }^{\mathrm{a}}$ Região. Apelação Cível 5.440/05 (90.02.05064-0). $2^{\mathrm{a}}$ Turma Especial. Julgado em 24/10/2005). 
jurídica, ou até mesmo lançando esta em domínio público, por meio de apostilamento desta em outros registros de marcas posteriores ${ }^{392}$.

\subsubsection{Palavras de idiomas estrangeiros}

Com a globalização, há crescente uso de palavras estrangeiras para designarem produtos ou serviços. LADAS comenta que, se a tradução da palavra estrangeira corresponder a um elemento comum, necessário, vulgar ou descritivo, então a palavra estrangeira também será considerada de uso comum com relação imediata com o produto ou serviço designado, logo irregistrável. ${ }^{393}$

Do outro lado, ASCARELLI entende que as palavras e suas traduções, se consideradas de uso comum, vulgares, genéricas ou descritivas, não podem ser apropriadas exclusivamente, mesmo que as palavras pertençam a idiomas mortos. ${ }^{394}$

Apesar do artigo 6 quinquies c-1 da CUP afirmar que a lei nacional será aplicada na análise da distintividade dos sinais propostos, tal artigo não dispõe a mesma regra sobre traduções. Tal artigo é responsável pela aplicação do Princípio do telle quelle (tal qual em Francês), que estatui que a marca, se deferida em seu país de origem, gozará do direito de ser deferida tal qual sua apresentação em seu país de origem. O INPI não tem demonstrado jurisprudência administrativa organizada em relação ao referido dispositivo legislativo.

Na verdade, a visão da CUP era a de facilitar o registro de marcas em virtude das diferenças linguísticas experimentadas pelos titulares de marcas que já eram exportadas no século XIX. Tal entendimento pode ser encontrado nas razões explicativas de BODENHAUSEN sobre o princípio do telle quelle, ao ensinar que "[o] artigo 6 quinquies se refere a uma situação excepcional (...) Com o intuito de diminuir a influência dessas diferenças sobre os registros de marca, a disposição em análise coloca o princípio de que uma marca devidamente registrada no país de origem será admitida para

\footnotetext{
${ }^{392}$ BARBOSA, Denis. Proteção das marcas... Op. cit. p. 127.

${ }^{393}$ LADAS, Steven. Patents, trademarks and related rights: national and international protection. v.2. Cambridge: Harvard University Press, 1975. § 576, p. 1008.

${ }^{394}$ ASCARELLI, Tullio. Op. cit. pp. 515/517.
} 
apresentação e ali protegidas como tal em outros países da União, sob as reservas indicadas nesse artigo". 395

A AIPPI já enfrentou esse problema e concluiu os trabalhos de resposta à Questão $135^{396}$, demonstrando ser necessário verificar se o elemento nominativo estrangeiro de uso comum, descritivo, vulgar ou genérico, é interpretado pela população como tal. Em caso positivo, o elemento estrangeiro será interpretado como irregistrável. SCHMIDT $^{397}$ cita alguns exemplos de elementos estrangeiros também considerados de uso comum em nosso país: HOT DOG, ABAT-JOUR, SOUTIEN, HAMBURGER.

Do contrário, em não havendo interpretação de que o elemento estrangeiro não penetrou a ponto de ser compreendido pelo interpretante como de uso comum, o mesmo será considerado distintivo já que não há associação direta entre o elemento e produto ou serviço designado. Nossos tribunais já ponderaram sobre esse tema, concluindo que a palavra POMODORO ${ }^{398}$, em que pese seu significado imediatamente relacionado com seus os produtos, não gera confusão entre os consumidores por não serem utilizadas pela população de modo a caracterizá-la como o sinônimo do produto ou serviço designado.

O entendimento contrário também foi expressado pelos tribunais brasileiros quando decretaram ausência de distintividade das marcas MICROSOFT ${ }^{399}$, JUST FOR $\mathrm{MEN}^{400}, \mathrm{CHARTER}^{401}$, DELICATESSEN ${ }^{402}$, os dois últimos citados por SCHMIDT ${ }^{403}$, tendo em vista seu significado imediatamente ligado aos produtos listados pelas marcas.

\footnotetext{
${ }^{395}$ BODENHAUSEN, G.H.C. Guide d'application de la Convention de Paris pour la protection de la propriété industrielle (telle que revise a Stockholm en 1967). Suíça: BIRPI, 1969. Traduzido livremente do original.

${ }^{396}$ Disponível no link https://www.aippi.org/download/commitees/135/RS135English.pdf. Acessado em 21/11/2011.

${ }^{397}$ SCHMIDT. Marcas em semiótica... Op. cit. Pág. 80.

398 TJSP. $8^{\text {a }}$ Câmara Cível, Ap. Cível 71.568-1, relator Desembargador Arthur de Godoy, publicado RT v. 647, pp. 61/62. Apud SCHMIDT. Marcas em semiótica... Op. cit. p. 80.

${ }^{399}$ TJSP. Ap. Cív. no 91.02.00482-8, $1^{\text {a }}$ Turma, Rel. Juiz Clelio Erthal. Julgado em 28/11/1994. “[S] endo a expressão MICROSOFT de uso comum, empregada na área de computadores, especificamente a dos chamados 'micros', não pode ser monopolizada por uma empresa para identificar, com exclusividade, os seus produtos, face ao impedimento ao art. 65, item 6, do Código de Propriedade Industrial”.

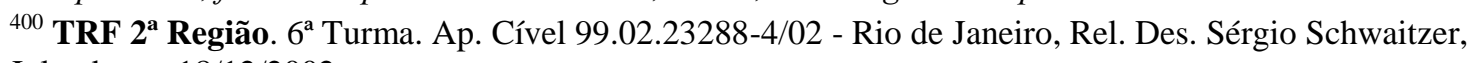
Julgado em 18/12/2002.

${ }^{401}$ STJ. $4^{\text {a }}$ Turma, REsp 9149/SP, Rel. Min. Cesar Asfor Rocha, DJU 14/04/1997.

${ }^{402}$ STJ. $3^{\text {a }}$ Turma, REsp n ${ }^{\circ}$ 62.754/SP, Rel Min. Nilson Naves, publicado RSTJ 1112/163.

${ }^{403}$ SCHMIDT. Marcas em semiótica... Op. cit. p. 80.
} 


\title{
3.1.1.3. Jurisprudência comentada
}

\author{
(a) Caso LAMAC ${ }^{404}$
}

APELAÇÃO CÍVEL - PROPRIEDADE INDUSTRIAL - REGISTRO DE MARCAS - POSSIBILIDADE - CONFUSÃO AO PUBLICO CONSUMIDOR NÃO OCORRÊNCIA - MARCAS FRACAS QUE REMETEM À EXPRESSÃO DE USO COMUM - MARCAS MISTAS DOTADAS DE SUFICIENTE DISTINTIVIDADE - CONCESSÃO DOS REGISTROS DENTRO DOS PARÂMETROS DO ARTIGO 124, VI DA LPI. 1-Recursos nos quais se discute se a anterioridade do registro do nome comercial da empresa-apelante, LAMAC LABORATÓRIO MÉDICO DE ANÁLISES CLÍNICAS LTDA., e também do depósito dos seus registros marcários, têm o condão de impedir os registros da empresa-apelada, LABORATÓRIO DE ANÁLISES CLÍNICAS DAS NAÇÕES LTDA.; 2- As marcas em cotejo são formadas pelo termo "LAMAC" (da apelante) e "LANAC" (da apelada) que são expressões cuja composição foi feita pela aglutinação das letras iniciais das expressões de uso comum que compõe as denominações sociais das empresas em litígio da seguinte forma: $L A M A C=L A$ de LABORATÓRIO + M de MÉDICO + A de ANÁLISES + C de CLÍNICAS e LANAC = L de LABORATÓRIO + ANA de ANÁLISES + C de CLÍNICAS; 3- As siglas "LAMAC" e "LANAC" dizem respeito a uma expressão de caráter geral e comum que é "Laboratório de Análises Clínicas" e que é usada por empresas que atuam na mesma área das empresas litigantes, ou seja, "serviços de laboratório e de análises clínicas". As marcas da empresa-apelada foram concedidas dentro dos parâmetros legais do artigo 124, inciso VI da LPI, uma vez que se revestiram de suficiente distintividade, na medida em que foram constituídas na forma mista; 4Empresas que utilizam sinais deste gênero, seja na composição do seu nome comercial ou de sua marca, acarretam para si a possibilidade de arcar com a convivência com outros sinais assemelhados, como no caso em tela. Assim, anterioridade do registro do nome comercial e do depósito das marcas da apelante não acarretam a nulidade dos registros marcários da apelada, tendo em vista que se tratam de marcas fracas, cujo grau de proteção é reduzido, pois remetem a termos habitualmente usados por empresas que atuam na área de "serviços de laboratório e de análises clínicas", merecendo destaque, ainda, o fato das marcas em análise serem de natureza mista e as empresas em litígio terem sede em estados diferentes; 5- Recursos conhecidos e improvidos.

Comentários: O TRF da $2^{\mathrm{a}}$ Região enfrentou o caso de possível conflito entre as marcas LAMAC e LANAC, ambas designando serviços de análises clínicas. Em que pese a similitude entre as marcas, o tribunal interpretou que ambas deveriam conviver pois "LAMAC" e "LANAC" dizem respeito a uma expressão de caráter geral e comum que é "Laboratório de Análises Clínicas" e que é usada por empresas que atuam na mesma área

\footnotetext{
${ }^{404}$ TRF 2 $^{\mathbf{a}}$ Região. Ap. Civ n ${ }^{\circ}$ 2008.51.01.813841-7 Primeira Turma Especializada - Julgado em
} 26/04/2011. Rel. Des. Fed. Abel Gomes. Julgado em 26/04/2011. 
das empresas litigantes, ou seja, "serviços de laboratório e de análises clínicas". O tribunal ainda concluiu que a integridade material de ambas as marcas não era capaz de impedir a outra de coexistir, demonstrando que marcas pouco distintivas possuem integridade distintiva reduzida. $O$ tribunal assim se manifestou expressando que "[E]mpresas que utilizam sinais deste gênero, seja na composição do seu nome comercial ou de sua marca, acarretam para si a possibilidade de arcar com a convivência com outros sinais assemelhados, como no caso em tela".

\section{(b) Caso TICKET ${ }^{405}$}

"EMENTA PROPRIEDADE INDUSTRIAL. MARCA COMERCIAL. "TICKET" TERMO DE USO COMUM. MARCA FRACA. DISTINGUIBILIDADE. A palavra TICKET é expressão de uso comum, traduzindo-se em marca dita "fraca" que, por sua natureza, para efeito de aferição de sua distinguibilidade em relação a outras que incluam o mesmo vocábulo, não exige o mesmo rigor que as marcas ditas "fortes". Não é de ser declarada nulidade de registro marcário nominativo consistente na expressão PLAYTICKET, sobretudo quando se tem em vista a existência de uma extensa lista de marcas que contêm o mesmo signo "TICKET", todas convivendo no mercado. Apelo desprovido".

Comentários: Nessa decisão do TRF da $2^{\text {a }}$ Região, apesar da intenção da titular da marca TICKET em discutir que o referido termo adquiriu distintividade pelo uso extensivo da marca, o tribunal compreendeu que o termo é de uso comum para designar cartões de recarga para uso em estabelecimentos comerciais do ramo alimentício. Diferentemente do julgado do caso LAMAC, os Desembargadores manifestaram entendimento de que a aglutinação de dois elementos, sendo um de uso comum, seria suficiente para que o mesmo fosse validado como marca. Ademais, os Desembargadores concordaram que TICKET era uma marca fraca e "para efeito de aferição de sua distinguibilidade em relação a outras que incluam o mesmo vocábulo, não exige o mesmo rigor que as marcas ditas "fortes".

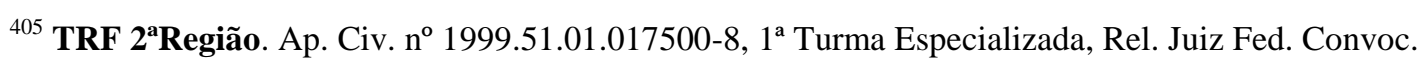
Marcello de Souza Granado. Publicado no DJ 03/04/2009. 
(c) Caso EBONY $\mathrm{E}^{406}$

"PROPRIEDADE INDUSTRIAL. PROCESSUAL CIVIL. EMBARGOS INFRINGENTES. AÇÃO DE NULIDADE DE REGISTRO MARCÁRIO. EBONY E ÉBANO. EXPRESSÕES RELACIONADAS AOS AFRODESCENDENTES. A expressão ÉBANO, em português ou EBONY, em inglês, é frequentemente empregada para identificar os afrodecesdentes, invocando, pois, no caso concreto, uma qualidade especial de um produto, merecendo, portanto, receber proteção de marca fraca, ou seja, ter de suportar o ônus da convivência pacífica. Embargos Infringentes conhecidos e improvidos".

Comentários: O TRF da $2^{\text {a }}$ Região compreendeu que os elementos EBONY e ÉBANO são intimamente relacionados a um determinado nicho de mercado, designando vulgarmente os afrodescendentes, e por isso, impôs a convivência de ambas as marcas, sendo que o elemento de uso comum não foi capaz de gerar direito de excluir o outro concorrente do uso de sua marca.

\section{(d) Caso FRUT ${ }^{407}$}

“APELAÇÕES - REMESSA NECESSÁRIA - PROPRIEDADE INDUSTRIAL COLIDENNCIA ENTRE MARCAS - EXPRESSÃO DE USO COMUM RECURSOS IMPROVIDOS I - A sistemática da lei, no que diz respeito a expressões de uso comum, não tem por escopo impedir o registro, mas vedar a concessão em caráter exclusivo, nos casos em que o significado corriqueiro da palavra possa de alguma forma invocar o produto, ou suas qualidades, ainda que remotamente - ou não teria o legislador inserido a ressalva "salvo quando revestidos de suficiente distintividade", inserto no artigo 124, VI, da LPI. II Sabe o legislador que a linguagem é instrumento imprescindivel a todas as atividades humanas, exigindo, por óbvio, que o uso de uma expressão extraída de um idioma vivo - a título de marca - importe em grande dose de criatividade do interessado, de modo a lhe conferir um novo significado, sem prejuízo daquele já empregado corriqueiramente pelos falantes da língua, sob pena de traduzir-se em título sem capacidade de impedir outros registros (com a mesma expressão) resultando no que a doutrina denomina de "marca fraca”. III - Entendimento sobejamente adotado pelo INPI no dia a dia de suas atribuições, e que pode ser conferido em seu cadastro, constituído por inúmeras marcas, como bem visto na sentença, que se utilizam das expressões FRUT E FRUIT. IV-Apelações e Remessa Necessária improvidas”.

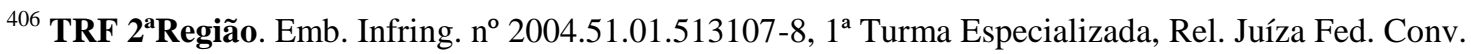
Márcia Helena Nunes, DJ 11/02/2009.

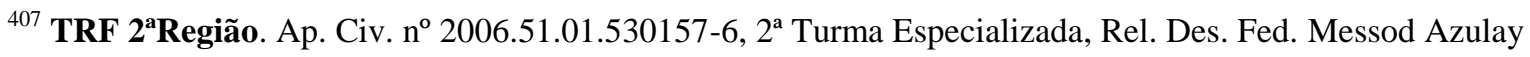
Neto, Publicado no DJ 10/07/2009.
} 
Comentários: Os elementos FRUT e FRUIT foram considerados de uso comum pelo TRF da $2^{\mathrm{a}}$ Região, mesmo designando produtos que remotamente são descritos pelas marcas. Ou seja, é de se perceber que o grau de distintividade também é objeto de análise subjetiva e sensorial por parte do interpretante, como reza a Semiótica. Logo, há de se ponderar que elementos, apesar de descreverem indiretamente características ou qualidades de um determinado produto ou serviço, podem ser interpretados como irregistráveis por falta de distintividade. Importante transcrever parte do entendimento do tribunal a respeito da sistemática da LPI sobre expressões de uso comum, quando afirma que o sistema "não tem por escopo impedir o registro, mas vedar a concessão em caráter exclusivo, nos casos em que o significado corriqueiro da palavra possa de alguma forma invocar o produto, ou suas qualidades, ainda que remotamente - ou não teria o legislador inserido a ressalva "salvo quando revestidos de suficiente distintividade", inserto no artigo 124, VI, da LPI".

\subsection{2 "Os caminhos da distintividade"}

As marcas são bens intelectuais dinâmicos que experimentam mutações linguísticas com o seu uso pelos titulares e pela sociedade. Elementos de uso comum alcançam distintividade através do uso ou sinais distintivos deixam de sê-los pelo uso desenfreado dos mesmos como gêneros dos produtos ou serviços por eles designados.

A integridade material desses signos muda de acordo com o uso. Daí, a expressão "caminhos da distinvidade", pois denota dinamismo, mudanças ou alterações.

\subsubsection{A aquisição de distintividade pelo uso}

O princípio do secondary meaning tem sua aplicação às marcas compostas por palavras ou imagens que são de uso comum, designativas de qualidade ou descritivas, ou seja, que de certo modo sugerem características inerentes aos produtos ou serviços por elas cobertos, ou mesmo descrevem-nos, ainda que indiretamente.

Segundo J. Thomas MCCARTHY, secondary meaning constitui "[U]m novo significado que é atribuído a uma palavra ou símbolo não-intrinsecamente distintivo, pelo qual clientes usam essa palavra ou símbolo como marca registrada ou marca de serviço 
para identificar e distinguir uma única fonte comercial", ${ }^{408}$ Essa segunda significação, ou significação secundária, a de marca e produtos ou de serviços, coexiste com a primeira significação, a original.

Sobre secondary meaning, Margreth BARRETT destaca que "[A] definição clássica de significado secundário vem de G\&C Merriam Co. vs. Saalfield, 198 Fed. 369, 373 (6th Cir. 1912): uma palavra ou frase originalmente incapaz de apropriação exclusiva com relação a um produto no mercado, por ser geograficamente ou de outra forma descritiva, pode no entanto ter sido usada por um tempo ou de modo tão exclusivo por um fabricante, em relação a seus produtos, que em tal mercado e para tal segmento de consumidores a palavra ou frase corresponde à noção de que o produto é daquele fabricante; em outras palavras, tornou-se para eles a marca do produto. Então diz-se que a palavra adquiriu um significado secundário". 409

SCHMIDT $^{410}$ comenta que secondary meaning é um fenômeno que faz com que um signo comum, originalmente desprovido de distintividade, adquira pelo uso empresarial a capacidade de identificar um produto ou serviço de outro, tornando-se passível de proteção como marca. Para TINOCO SOARES, secondary meaning é " $a$ aquisição do sentido secundário é uma questão de fato e uma grande variedade de provas é rotineiramente considerada pelas Cortes de Justiça para alicerçar as suas decisões". 411

Denis BARBOSA explica que o secondary meaning é "[A] terceira hipótese de efeito do conhecimento da marca pelo público é o fato de que o uso ou a divulgação de um nome tenha sido de tal intensidade ou por tanto tempo que o público tenha se habituado a associar um símbolo a uma origem de produtos ou serviços, mesmo em condições que vedariam seu registro por falta de distinguibilidade”. 412

\footnotetext{
${ }^{408}$ MCCARTHY, J. Thomas; SCHECHTER, Roger E.; FRANKLYN, David J. McCarthy's Desk Encyclopedia of Intellectual Property. Third Edition. Washington: BNA Books, 2004. p. 544. Traduzido livremente de: "[A] new meaning that attaches to a non-inherently distinctive word or symbol, by which costumers use that word or symbol as a trademark or service mark to identify and distinguish a single commercial source".

${ }^{409}$ BARRETT, Margreth. Intellectual Property: cases and materials. 2a edição. St. Paul: West Publishing, 2001. p. 624).

${ }^{410}$ SCHMIDT, Lélio Denicoli. Marcas em Semiótica... Op. cit. p. 91.

${ }^{411}$ SOARES, José Carlos Tinoco. Concorrência Desleal vs. Trade Dress e/ou Conjunto-Imagem. São Paulo: Autor, 2004, p. 75.

${ }^{412}$ BARBOSA, Denis Borges. Uma introdução... p. 891.
} 
FRÓES cita BODENHAUSEN em uma leitura sobre a regra do artigo 6 quinquies C-1 da CUP, o qual comentou que as circunstâncias de fato podiam demonstrar "[q]ue uma marca não será distintiva no longo período pelo uso de um segundo significado que o torna distintivo". ${ }^{413}$ Tal artigo excetua a regra do artigo 6 quinquies B-2 que sugere o impedimento do registro de marcas "[d]esprovidas de qualquer caráter distintivo ou então exclusivamente composta por sinais ou indicações que possam servir no comércio para designar a espécie, a qualidade, a quantidade, o destino, o valor, o lugar de origem dos produtos ou a época da produção, ou que se tenham tornado usuais na linguagem corrente ou nos hábitos leais e constantes do comércio do país em que a proteção é requerida".

O ordenamento jurídico não pode permitir que marcas enquadradas na situação acima não sejam tuteladas sem a devida proteção legal. Haverá assim tutela à marca que alcançou distintividade quando houver associação mental por parte dos consumidores, entre a palavra comum ou descritiva e a marca, de modo que ela não evoque, no contexto do seu uso em determinados produtos ou serviços, um mero termo do dicionário, mas sim um sinal distintivo e característico, e ocorrendo influência do fator temporal, qual seja, o uso prolongado dessa marca a ponto de criar por si só uma distintividade. Corroborando com essa construção, a CUP dispõe em seu artigo 6 quinquies C-1 que "[P]ara determinar se a marca é suscetível de proteção, deverão ser levadas em consideração todas as circunstâncias de fato, particularmente a duração do uso da marca,(...)”.

O tribunal americano já decidiu no mesmo sentido quando decretou que “[E]ssa distintividade adquirida é conhecida como 'secondary meaning' porque é o significado adquirido em segundo lugar no tempo em relação ao significado primário da palavra. O significado secundário necessita apenas que os consumidores associem a palavra ou símbolo com uma simples, embora anônima, origem comercial". ${ }^{414}$

\footnotetext{
${ }^{413}$ FRÓES. Op. cit. p. 87. Traduzido de: “[q] u’une marque qui n'etait pás distinctive, à la longue a acquis par l'usage um sens second qui la rend distinctive".

${ }^{414}$ MCCARTHY, J. Thomas; SCHECHTER, Roger E.; FRANKLYN, David J. Op. cit. p. 544. Traduzido de: "This acquired distinctiveness is known as "secondary meaning" because it is a meaning acquired second in time to the primary meaning of the word. Secondary meaning requires only that customers associate the word or symbol with a single, albeit anonymous, commercial source".
} 
Nos Estados Unidos, país de maior tradição na aplicação da teoria do secondary meaning, as provas admitidas para demonstrar a distintividade são o uso substancial e contínuo da marca por período igual ou superior a 5 (cinco) anos; a titularidade de registro(s) precedentemente concedido(s) para a mesma marca, para produtos ou serviços relacionados; gastos em publicidade, declarações ou pesquisas de mercado que confirmem a distintividade da marca. ${ }^{415}$

Sob o ponto de vista europeu, as Resoluções n. 89/104, de 21.12.1988, e 40/94, de 20.12.1993 destacam os requisitos para o alcance de distintividade por elementos intrinsecamente de uso comum: (a) o mercado atingido pela marca; (b) a intensidade, o âmbito geográfico e a duração do uso da marca; (c) o valor investido pelo titular na promoção da marca; (d) a proporção da classe relevante de consumidores que identificam a marca como originária de uma determinada empresa; (e) Certidões emitidas por Câmaras de Comércio e Indústria ou de associações profissionais.

Outrossim, a legislação brasileira não proíbe a possibilidade que um sinal ser considerado distintivo através de seu uso, mesmo que não se observe decisões administrativas emanadas do INPI nesse sentido. Caso o INPI admitisse o artigo 6 quinquies C-1 da CUP e o artigo 15.1 do TRIPs como arcabouços legais possíveis de equalizarem direitos no Brasil, talvez experimentar-se-ia decisões de constituição de registros de marca com base em provas de aquisição de distintividade através do uso da marca. O Poder Judiciário já se pronunciou a respeito quando anulou a decisão de indeferimento da marca SEDA para produtos de higiene pessoal como xampus e condicionadores. O acórdão foi muito enfático ao reconhecer as propriedades que a palavra SEDA denota em relação a esses tipos de produtos, mas persistiu em apontar a fama alcançada pela marca junto ao público consumidor como fator determinante para o alcance da suficiência distintiva e sua capacidade de diferenciar seu titular dos demais concorrentes. 416

Uma marca por si só tem de ser dotada de distintividade, em virtude de sua própria razão de ser. Há marcas, entretanto, que por seu maior grau de abstração em

${ }^{415}$ KINNEY \& LANGE P.A. Intellectual Property Law for Business Lawyers. St. Paul: West, 1996, p. 220,274 e 298.

${ }^{416}$ TRF 2a Região. Apelação Cível 384.930/07 - Rio de Janeiro (2003.51.01.517847-9) - 2 ${ }^{\mathbf{a}}$ Turma

Especializada - Rel. Des. Mesod Azulay Neto - Julgado em 27/02/2007. 
relação ao produto a que se referem, são revestidas de uma maior distinção. Quanto maior a distintividade de uma marca, maior será sua proteção jurídica, ou seja, premia-se a integridade material da marca genuinamente distintiva com uma tutela jurídica mais intensa a marca que mais se afasta da referência, ainda que indireta, ao produto.

A marca fraca é muito mais sujeita à presença de competidores e menos defensável num caso de contrafação, exceto nas hipóteses em que, por longo uso, o signo tenha conseguido uma "significação secundária", como por exemplo a marca CASA DO PÃO DE QUEIJO. ${ }^{417}$

Nesse sentido, há marcas que, em razão do seu uso prolongado e bem conduzido pela empresa titular, embora inicialmente fracas, passam a ser identificadas diretamente com o produto ou serviço coberto de tal forma que o seu termo nominativo adquire significado próprio distinto do original, isto é: o público em geral, no momento de ver ou ouvir a marca no seu contexto, não pensa no sentido comum da palavra, mas sim reconhece nela uma designação marcária de um produto ou serviço com características próprias, com as quais há bastante tempo se familiarizou e que sabe distinguir dos demais produtos ou serviços análogos. No Brasil, alguns exemplos são as marcas nominativas concedidas pelo INPI: POLVILHO ANTISSÉPTICO ${ }^{418}$, ULTRAGAZ ${ }^{419}$, MICRODIGITAL ${ }^{420}$, ALPARGATAS $^{421}$, SEDA $^{422}$ e KITCHENS. $^{423}$

Lendo-se os exemplos notórios acima, não fica difícil concluir que dois são os mínimos requisitos para a interpretação e aplicação desse fenômeno: (a) uso prolongado da marca e (b) associação por parte dos consumidores entre a palavra e a marca.

\footnotetext{
${ }^{417}$ BARBOSA, Denis. Proteção das marcas... Op. cit. p. 72.

${ }^{418}$ TFR. Apelação Cível 102.635/85 - Rio de Janeiro - (5.796.156) - 5 Turma - Ministro Pedro Acioli.

${ }^{419}$ TFR. Apelação Cível 63.029/ Rio de Janeiro - (1631969) - 5a Turma - Rel. Min. Sebastião Alves dos Reis - Fonte: Diário de Justiça, p. 12878, 17 dez. 1981.

${ }^{420}$ TRF $2^{\text {a }}$ Região. Apelação Cível 89.02.03964-1/90 - Rio de Janeiro - $1^{\text {a }}$ Turma - Rel. Des. Clélio Erthal - . Julgado em 04/04/1990.

${ }^{421}$ TJSP. Apelação Cível 82.301-1/87 - São Paulo - 2 a Câmara Cível - Rel. Des. Cézar Peluso - Julgado em 10/02/1987 - Jurisprudência Brasileira, v. 144, p. 179-181, 1989.

${ }^{422}$ TRF 2a Região. Apelação Cível 384.930/07 - Rio de Janeiro (2003.51.01.517847-9) - 2ª Turma Especializada - Rel. Des. Mesod Azulay Neto - Julgado em 27/02/2007.

${ }^{423}$ TRF 2 ${ }^{\text {a }}$ Região. Apelação Cível 2007.51.01.803363-9 - Primeira Turma Especializada. Rel. Juíza Fed. Conv. Márcia Helena Nunes. Julgado em 10/09/2009.
} 


\subsubsection{A vulgarização de uma marca}

O processo de degenerescência de uma marca consiste na gradual utilização da mesma pelo titular ou por terceiros como o gênero do seu produto ou serviço.

Sob o ponto de vista da sua integridade, o processo de vulgarização enfraquece a integridade material da marca de modo que o público a interprete como sendo o próprio produto, deixando de ser marca para se tornar um elemento de uso comum. Diversos são os titulares que tentaram e tentam evitar que suas marcas vertem ao domínio comum e como exemplos $^{424}$ citam-se as ex-marcas ISOPOR, CELLOPHANE, CORN FLAKES, ESCALATOR, KEROSENE e ASPIRIN, todas consideradas degeneradas de sua integridade material pelos tribunais americanos.

Em havendo vulgarização de uma marca, o seu uso agora descritivo é permitido a todos, pois a marca, antes propriedade de um titular, agora passa a ser res communis omnium.

FRÓES, para explicar o fenômeno da degenerescência de marca, cita Pasquale Cipro Neto, que interpreta tal processo sob o ponto de vista gramatical, explicando que a metonímia consiste na designação de um objeto por uma palavra que tenha com ele relação de contigüidade ou de adjacência. FRÓES transcreve algumas palavras do referido autor: "A figura da metonímia está mais do que presente em nosso cotidiano. Quando chamamos de 'gilete' qualquer lâmina de barbear, empregamos a metonímia. Na origem, 'gilete' é o sobrenome de King Champ Gillette, inventor e primeiro fabricante desta lâmina de barbear. O sobrenome do 'pai' da lâmina deu origem ao nome da fábrica. Em seguida, o produto passou a ter o nome do produtor". ${ }^{425}$

O uso da primeira pessoa do plural no trecho acima inclui o consumidor no processo de vulgarização. Se é a percepção do consumidor que torna a marca distintiva, a

\footnotetext{
${ }^{424}$ SCHMIDT. Marcas em semiótica... Op. cit. pp.146/147. De acordo com o autor, outros exemplos de marcas vulgarizadas: MARTELINHO DE OURO, COTONETE, GILLETTE, MACACÃO, ISOPOR, ZÍPER, JIPE, PICK-UP, MOTOCA, OFF ROAD, JET SKI, FÓRMICA, QUEROSENE, LANOLINA, BAQUELITE, CREOLINA, CELOFANE, SPA, GRANOLA, CATUPIRY, MAIZENA, CHICLETE, WALKMAN, LYCRA, ÍNDIGO, CASHMERE, VHS, XEROX.

${ }^{425}$ FRÓES. Op. cit. p. 93.
} 
mesma percepção, quando degenerada, pode suprimir esta qualidade. ${ }^{426}$ Logo, de forma ativa, o consumidor é elemento importante da equação, tanto no que tange ao fenômeno do secondary meaning, quanto no de degeneração de um signo distintivo, pois somados à utilização da marca como sinônimo do produto pelo titular e pela concorrência, o consumidor determina como o signo está sendo utilizado, se com seu significado marcário ou semântico. ${ }^{427}$

FRÓES continua afirmando que nem sempre o uso impróprio de uma marca, como se fosse palavra de uso comum, se deve à omissão de seu titular. Às vezes ocorre que, ao ser lançado no mercado, um produto novo e original passa a ser identificado pelo consumidor pela própria marca adotada por seu fabricante. ${ }^{428}$ Para explicar essa possibilidade, o autor cita o exemplo da marca XEROX, marca de fantasia, inspirada em palavra grega. Todavia, apesar da utilização da marca pelo público como designativa de serviços de fotocópia ${ }^{429}$, a marca não foi julgada como sinônimo do referido serviço e por isso, continua distintiva, mantendo sua integridade material e sua capacidade de gerar efeitos perante terceiros. Outros exemplos de marcas que tentam evitar sua vulgarização são a já citada GILLETTE, e ainda COTONETE, CATUPIRY e LYCRA.

ASCARELLI entende que “[p] ara que a vulgarização ocorra é necessário que o sinal distintivo de produto de um empresário, passe a indicar um gênero de produtos $e$ os produtos de empreendedores diferentes em relação à característica comum geral (art. 41 n. 1 l. marcas), podendo, agora, ser usado como um termo genérico para se referir a todos os gêneros de produtos relacionados". 430

\footnotetext{
${ }^{426}$ SCHMIDT. Marcas em semiótica... Op. cit. p. 153.

${ }^{427}$ Cf. BARBOSA, Cláudio. Op. cit. p. 156. Em outro exemplo, Claudio BARBOSA comenta que o elemento garoto é do vernáculo próprio para fazer alusão a uma criança ou adolescente do sexo masculino, todavia, ninguém assim entende quando se trata de chocolates e afins de uma das maiores marcas nacionais que ostenta a mesma palavra. $\mathrm{O}$ uso continuado de garoto para se referir aos chocolates de variados tipos gerou uma associação automática nos consumidores e o termo ganhou um segundo significado que passa a destacar-se, no caso dos chocolates, mais do que o seu original.

${ }^{428}$ FRÓES. Op. cit. p. 94.

${ }^{429}$ Com frequiência, a marca XEROX é utilizada em textos jornalísticos como sinônimo de fotocópia. Além disso, há uso corriqueiro da marca XEROX por empresas do serviço de fotocópias, como se todas as máquinas utilizadas fossem da famosa empresa The Xerox Company.

${ }^{430}$ ASCARELLI. Teoria... Op. cit. p. 323. Tradução livre do original: "Ip]erché la volgarizzazione abbia luogo è necessário che Il segno, da segno distintivo di prodotto di um imprenditore, passi ad indicare un genere di prodotti e cosi prodotti di imprenditori diversi in relazione a comuni catteristiche generiche (art. $41 \mathrm{n} .1$ l. marchi), potendo allora usato come denominazione genérica per indicare tutti i prodotti apparanti al genere".
} 
A rigor, a degeneração é um processo de perecimento de um direito adquirido que, enfraquece a integridade material da marca chegando até o perdimento total de seu poder distintivo, por não ser utilizado corretamente por seu titular, ou porque o próprio público passou a adotá-lo como designativo do produto, sem que o titular tivesse qualquer atitude a respeito.

A vulgarização de uma marca a torna imprestável para fazer cessar o uso por terceiros pelo simples fato do mesmo não constituir mais direito privado de um titular, mas sim res communis omnium, portanto pertencente a todos. Esse entendimento é compartilhado por diversos autores como POUILLET ${ }^{431}$ e ASCARELLI. ${ }^{432}$

SCHMIDT ensina que "[A]o degenerar e transformar-se num nome comum, a marca perde aquilo que lhe é mais fundamental e que explica sua própria razão de ser. A passagem de um nome próprio a um nome comum não só permite como torna desnecessário que todos o utilizem indistintamente, sempre que a ocasião semântica se apresentar". E continua o autor comentando que "[A] marca vulgarizada se torna parte das formas de expressão que compõem o idioma e não consegue mais distinguir um produto ou serviço de outro. A degeneração das funções que são próprias à marca cria um conflito entre o direito privado ao seu uso exclusivo e o direito público ao livre uso dos vocábulos integrantes do idioma". ${ }^{433}$

Para Denis BARBOSA, o fluxo simbólico interage com o econômico, mas com efeitos jurígenos. Uma marca solidamente registrada pode perder a exclusividade pelo fenômeno da generificação, ou seja, no fluxo de comunicação a marca deixa de ser daquele produto ou serviço, originário do titular, e passa a ser um descritor funcional que emigra para o domínio comum. O autor, citando José Antonio Faria CORREA, afirma que esse fenômeno é uma "patologia da notoriedade". ${ }^{434}$

\footnotetext{
${ }^{431}$ POUILLET. Op. cit. p. 68.

${ }^{432}$ ASCARELLI, Tullio. In tema di caduta del marchio in dominio publico. In Studi in tema di contrati. Milão: Giuffrè, 1952, p. 517.

${ }^{433}$ SCHMIDT. Marcas em semiótica... Op. cit. p. 149.

${ }^{434}$ BARBOSA, Denis. Proteção das marcas... Op. cit. p. 51. Apud CORREA, José Antonio Faria. O fenômeno da diluição e o conflito de marcas. In RABPI, nº 37, nov./dez. 1998, p. 31.
} 
CORREA é hábil ao aplicar uma metáfora para explicar o fenômeno da patologia da notoriedade, anotando que "[a] notoriedade, no seu sentido mais amplo, é o fenômeno pelo qual a marca, tal qual um balão de gás, se solta, desprendendo-se do ambiente em que originariamente inserida, sendo reconhecida independentemente de seu campo lógico-sensorial primitivo. A notoriedade é correlata à genericidade. A genericidade é o negativo (= imprestabilidade universal para servir como elemento de identificação de um produto ou serviço, por refletir, no plano lógico-sensorial, o próprio produto ou serviço). A notoriedade é o positivo (=idoneidade universal, absoluta para servir de elemento de identificação de um produto ou serviço). Notoriedade é magia e magia é a capacidade de se criar o efeito sem a causa, produzindo do nada. Notória a marca, e a sua utilização impregna de magia qualquer produto, tornando-o vendável. A vendabilidade do produto emerge do poder de distinguir, do poder de atrair o público". ${ }^{435}$

Assim, as marcas de sucesso em seu ramo de atividade podem passar a ser utilizadas pela sociedade consumidora, como sinônimo do próprio produto ou serviço que ela designa, causando o fenômeno da degenerescência da marca, ou seja a marca torna-se o nome genérico do produto, perdendo assim o seu poder distintivo passando à res communis omnium. Tal ocorrência constitui, sem dúvida, externalidade nociva ao agente econômico que se torna vítima do seu próprio sucesso empresarial.

A degeneração, como patologia da notoriedade, ocorre pela força exagerada de comunicação do titular visando a identificação da marca com o produto, chegando a ser utilizada como o gênero em si por consumidores e concorrentes. Indícios comerciais não existem, mas não se admiraria se a marca BRASTEMP fosse reconhecida como elemento vulgarizado para eletrodomésticos, com seu principal slogan "NÃO É UMA BRASTEMP”.

A transformação de uma marca em um elemento de uso comum não é resultado de um estampido, mas sim de uma seqüência de atitudes dos consumidores e até mesmo dos concorrentes, sem intervenções em contrário do agente econômico, detentor do direito de uso exclusivo da marca. Tal dormência pode ser explicada pelos louros do sucesso da marca e pela repercussão causada pelo alvoroço mercadológico que acabam por confundir

${ }^{435}$ CORREA. O fenômeno da diluição... Op. cit. p. 31. 
os agentes econômicos que, ao invés de deixarem sua marca "cair na boca do povo", deveriam proteger a integridade material da mesma para evitar tal tragédia.

Diante do histórico envolvendo marcas famosas em processo de degenerescência do seu poder distintivo, os agentes econômicos são obrigados a agir forçando movimento contrário. É o caso da marca LYCRA, que com o slogan "SE TEM ESSA ETIQUETA, É LYCRA. SÓ LYCRA É DA DU PONT” maciçamente repetido nos veículos de comunicação e com medidas judiciais e extrajudiciais contra free riders, conseguiu evitar que seu vocábulo se tornasse gênero de tecido com elastano.

Caso interessante ocorreu na França com a marca BIC, cujo titular, Société BIC S.A., intentou medida judicial no início dos anos 80 contra a editora Société Éditions Julliard que permitiu que a marca BIC fosse utilizada com letras em diminutivo, dando a entender que a marca, na verdade, constituía o sinônimo para caneta esferográfica (crayon à bille). A empresa Société BIC S.A. demandou e ganhou a ação impedindo a utilização indevida da marca BIC como gênero do produto, sendo indenizada, inclusive. O caso foi julgado pelo Tribunal de Grande Instance de Paris em 17/09/1980. ${ }^{436}$

Outros casos interessantes julgados na França com o mesmo resultado, foram referentes às marcas CELLOPHANE ${ }^{437}$, repetindo o resultado do tribunal americano, e BOTOX. $^{438}$

\footnotetext{
${ }^{436}$ In Revue Internationale de la Propriété Industrielle et Artistique, n. 124, p. 275-277, jun. 1981. 437 ' $O$ termo celofane é formado do radical 'cello' evocando a palavra de celulose e terminação 'phane' referindo-se à transparência do produto, foi, na época de sua criação, uma nova palavra e uma denominação de fantasia. Não se pode impedir que um inventor ou seus cessionários para proteger como uma marca registrada, mesmo após o prazo da patente, o nome dado ao novo produto que ele criou, mesmo que nenhum outro termo poderia ser dado a este produto . O uso que foi feito dessa palavra na linguagem corrente científica ou administrativa posteriormente à apresentação da marca poderia afetar os direitos da empresa requerente em sua marca, especialmente quando se tem tomado todas as precauções para evitar que ocorram abusos". Cour de Cassation. Julgado em 11/05/1966. In: Revue Internationale de la Propriété Industrielle et Artistique, n. 68, pp. 75-79, Junho de 1967. Tradução livre do original.

438 "Os juízes acreditam que a utilização deste sinal é vulgarizado para designar a toxina em si e não a origem do produto, e isso não constitui um uso como marca, porque desta natureza. Analisando-se o recurso, a Suprema Corte declarou que 'o Tribunal de Recurso tem enfatizado que a marca tornou-se, por causa de seu proprietário, o nome comum no comércio do produto em causa. $\mathrm{O}$ tribunal estima que os juizes justificaram a sua decisão substituindo a extinção da marca por degenerescência pela extinção pela falta de uso. Tradução livre do original: "Les juges du fond ont estimé que l'usage de ce signe, couramment utilisé pour désigner la toxine elle-même et non l'origine du produit, ne pouvait constituer un usage à titre de marque en raison de ce caractère. Saisie d'un pourvoi, la Cour de cassation a précisé que 'la Cour d'appel' a fait ressortir que la marque était devenue, du fait de son propriétaire, la désignation usuelle dans le commerce du produit concerné. Elle estime alors que juges du fond ont justifié leur décision tout en substituant le motif de dégénéresnce à celui de la déchéance pour défaut d'usage". Cour de Cassation, Chambre commerciale.
} 
A justiça americana já decidiu pela degenerescência de marcas famosas por terem sido absorvidas pelo uso corriqueiro e pacífico da sociedade na designação do produto. ${ }^{439} \mathrm{O}$ caso THERMOS merece comentários pois o tribunal americano concordou com a possibilidade do titular da marca de garrafas térmicas ter contribuído para que a marca deixasse de possuir cunho distintivo e assim, perder sua integridade material. De acordo com o tribunal americano "[M]esmo que o tribunal não esteja convencido de que a perda de distinção da marca foi o resultado de alguma falha por parte da demandante, ao réu deve ser permitido o uso do termo de forma descritiva, uma vez que se tornou genérico de fato. Mesmo que uma minoria do público ainda reconheça o termo "Thermos" como uma marca, isso não exige a conclusão de que ao réu deve ser negado qualquer uso da marca, simplesmente faz necessário o tipo de decreto de proteção enquadrado pelo tribunal abaixo o qual garante que o uso pelo réu será claramente descritivo e não vai causar confusão". 440

A justiça brasileira também já julgou caso semelhante pacificando que CATUPIRY tornou-se designativo de um tipo de queijo cremoso. Veja-se que diante de tal processo, até mesmo os titulares de marcas famosas se vêem obrigados a agir em defesa do poder distintivo - integridade material - das mesmas, submetidos a custos de manutenção

Julgado em 01/01/2008. Société Allergan Société Jouve \& Age. In : Revue Internationale de la Propriété Industrielle et Artistique, n. 234, p. 9-11, oct./dec. 08.

${ }^{439}$ LANDES e POSNER. Op.cit. p. 169. "Um benefício da proteção da marca deriva do incentivo que essa proteção cria para investir recursos não na manutenção de qualidade mas na invenção de novos nomes ou símbolos, ou, menos claro, designs utilizados como marcas, como um forma e a cor da garrafa de Perrier ou a forma de uma Ferrari, mas desde o momento em que confinamos nossa atenção nas palavras. Marcas evoluem a linguagem em três direções. Elas aumentam o estoque de nomes de coisas, economizam em comunicação e custos de informação na forma como sugeridas. Elas criam palavras genéricas - palavras que denotam produtos inteiros, não apenas marcas individuais. "Aspirin”, "brasserie”, “cellophone”, "escalator", "thermos", "yo-yo", "dry ice”, e um número de outros nomes de produtos comuns foram marcas em algum momento - e n] ao importa o que digam, "Kleenex”, "Xerox", "Velcro" e "Rollerblades" são largamente utilizados para denotar produtos inteiros e também marcas individuais. Marcas também enriquecem a linguagem criando palavras ou frases que as pessoas valorizam value pelo prazer intrínseco e pelo valor da informação, tais como perfume "Pheremon" e a mistura de bolo "Swan's Down". Um estudo de 1985 apontou que a frequência de uso de marcas em livros best sellers americanos estava crescendo rapidamente, com nomes genéricos alcançando uma frequência impressionante de 160 nomes genéricos a cada 10.000 palavras (1.6 por cento)".

${ }^{440}$ United States District Court for the District of Connecticut n. 27.965. King-Seeley Thermos Co. v. Aladdin Industries, Incorporated. Julgado em 11/07/1963. Tradução livre do original: "[E]ven though the court is not convinced that the trademark's loss of distinctiveness was the result of some failure on plaintiff's part, the defendant must be permitted to use the term descriptively since it has become generic in fact. Even though a minority of the public still recognizes the term "Thermos" as a trademark, this does not require the conclusion that defendant must be denied all use of the mark; it merely makes necessary the kind of protective decree framed by the court below which ensures that defendant's use will be clearly descriptive and will not cause confusion". 
os quais podem ser demasiadamente altos, obrigando os agentes, às vezes, a desistirem de suas marcas.

No ramo hoteleiro, o STF já decidiu pela vulgarização da marca PALACE HOTEL, a qual foi considerada uma qualidade superior de hotel e não possui, portanto, conotação marcaria. ${ }^{441}$ No mesmo sentido, O TRF da $2^{a}$ Região decidiu que a marca PLAZA, embasado no entendimento do INPI de que a mesma era considerada fraca com o advento da expansão da utilização do termo em shopping centers, "[p]ermitindo o registro das marcas da Autora, levando em conta o conjunto formado pelas marcas e não cada um de seus elementos isoladamente, assim, sem direito ao uso exclusiva da marca Plaza". ${ }^{42}$ Note-se que o Tribunal utilizou a palavra integridade em sua ementa, o que permite a utilização de tal termo como elemento importante da marca.

Nos casos judiciais em que se apreciou a preservação de uma marca acometida pelo uso geral e generalizante, em muito pesou a inércia do titular quanto à recuperação semiológica da marca pelo domínio comum, como documentado pela dicionarização. ${ }^{443}$ Foi o caso da palavra fórmica através do julgado pelo $\mathrm{STF}^{444}$, que extraiu seu significado de fórmica do Dicionário Barsa como "material fenólico, usado como material isolante de eletricidade, revestimento de móveis". O Superior Tribunal entendeu que a vulgarização da marca FORMICA era tão gritante que entendeu que o vocábulo era "puramente genérico e de uso comum", não dando margem a qualquer outra interpretação diversa. Atualmente, o titular da marca FORMICA tenta por intermédio dos meios de comunicação, esclarecer que a marca FORMICA designa um comerciante dos demais e que para tanto, oferece seu produto com melhor qualidade. É uma tentativa de restabelecer a integridade material de uma marca perdida e dicionarizada.

Nesse processo de recuperação da integridade material da marca vulgarizada, os titulares devem imediatamente tomar providências para evitar o uso inadequado da

${ }^{441}$ STF, $1^{\text {a }}$ Turma, Recurso Extraordinário 49778, Rel. Min. Gonçalves de Oliveira, j. 28.06.1962, publ. RTJ v. 23, pp. 414-418.

${ }^{442}$ TRF 2 ${ }^{\text {a }}$ Região. $1^{a}$ Turma Especializada. AP. Civ. 1999.02.01.053095-5/05 - Rio de Janeiro. Rel. Juíza Marcia Helena Nunes. Julgado em 27/07/2005.

${ }^{443}$ BARBOSA, Denis. Proteção das marcas... Op. cit. p. 107.

${ }^{444}$ STF. RExt 107892/PR, $1^{\text {a }}$ Turma, Rel. Ministro Rafael Mayer, julgado em 23/05/1986. 
marca $^{445}$, assim que tiverem conhecimento que suas marcas vêm sendo utilizadas pelos concorrentes de forma indevida, como se referindo à marca como sendo o próprio produto (ex: recipiente de isopor) do titular.

Dois casos curiosos citados por SCHMIDT $^{446}$ são os das outrora marcas MARTELINHO DE OURO e GIBI. Ambas criadas para designar os serviços e produtos, hoje, óbvios, em função do uso corriqueiro de seu significado marcário como gêneros. Em nenhum dos dois casos, seus titulares foram capazes de evitar a vulgarização de suas marcas. Inclusive, a vulgarização da marca GIBI foi analisada pelo TRF da $2^{\mathrm{a}}$ Região, após tentativa do titular da marca em anular decisão administrativa de indeferimento em virtude da falta de distintividade do elemento vulgarizado. ${ }^{447}$

Ao fim, as principais causas da vulgarização de uma marca podem ser listados, em resumo: (i) ação desleixada do titular ao designar a marca como o sinônimo do produto; (ii) omissão do titular durante a utilização por terceiros de seu signo como gênero do produto; (iii) a inclusão da marca como gênero do produto em dicionários; e (iv) o surgimento de sinônimos da marca.

No dia-a-dia da análise de pedidos de registro de marcas pelo INPI brasileiro, a aplicação do princípio da distintividade é conduzida de forma subjetiva, sendo que os entendimentos variam entre os examinadores de marcas, mesmo que um guia tenha sido criado pelo INPI para a melhor compreensão do sistema de marcas pelos seus usuários. Tal guia, as Diretrizes de Análises de Marcas publicada no dia 28 de dezembro de $2011^{448}$, trouxe melhorias em relação ao documento que a antecedeu. No que diz à análise de pedidos compostos por elementos degenerados em sua distintividade, a LPI não abriga a possibilidade de impedir o registro declarando que a marca tenha sofrido degenerescência. Mas, a depender do processo de perda da distintividade e da forma como os examinadores captem essa informação, pedidos de registro de marca compostas pelo termo vulgarizado podem até ser deferidos, mas com ressalvas à falta de exclusividade da marca vulgarizada.

\footnotetext{
${ }^{445}$ BARBOSA, Denis. Proteção das marcas... Op. cit. pp. 108/109.

${ }^{446}$ SCHMIDT. Marcas em semiótica... Op. cit. p. 148.

${ }^{447}$ TRF 2 ${ }^{\text {a }}$ Região, $1^{\text {a }}$ Turma Especializada, Ap. Civ. 99.02.29657-2. Rel. Juíza Conv. Márcia Helena Nunes. Julgado em 27 de julho de 2005.

${ }^{448}$ http://www.inpi.gov.br/images/stories/downloads/pdf/diretrizes de analise de marcas 17-12-2010.pdf. Acessado em 14 de fevereiro de 2012. Uma nova versão foi lançada no dia 11 de dezembro de 2012, com a adição do capítulo sobre análise dos acordos de coexistência entre titulares distintos.
} 
Assim é que, no Brasil, a interpretação da degenerescência de uma marca ocorre nos tribunais, que podem determinar a total perda da integridade distintiva de uma marca. Porém, se e quando uma marca for considerada vulgarizada seja pelo mercado ou pelo Judiciário, espaço existe para discutir que a mesma não deixa de existir enquanto registro concedido pelo órgão competente.

\subsection{Os efeitos da vulgarização}

De acordo com Sérgio FERREIRA, não há hipótese para que um registro de uma marca seja extinto porque passou a designar o gênero do produto ou serviço. Para ele, "[a] marca que foi a primeira a distinguir um tipo de produto e este se tornou tão popular que a marca virou sinônimo do produto, cumpriu de maneira irretocável o seu papel como marca, que é de divulgar o produto com o seu nome. O titular desta marca não pode ser punido por ter cumprido a função social de uma marca". 449

Concordando à sua maneira, Denis BARBOSA comenta que "[p]ara que o registro de uma marca genérica possa vir a ser anulado, seja por via administrativa ou judicial, é preciso que a marca em questão não esteja apta a exercer sua função distintiva desde a data do depósito do seu pedido de registro. Uma marca que originariamente era distintiva e, com o passar do tempo, devido à sua fama, se tornou genérica, não pode em princípio ser extinta por essa razão". ${ }^{450}$

Nossos tribunais já se debruçaram sobre a impossibilidade de anular o registro de marca vulgarizada. O caso TICKET foi pontuado pelo afastamento da vulgarização da marca em função da atividade atenta do titular ao registrar as marcas a seu tempo e mantêla íntegra desde então. Diz assim o acórdão: "[N]ão se afigura jurídico e nem justo, concluir pela perda da exclusividade de marca, quando a vulgarização de seu emprego, decorreu da criatividade empresarial e esforço das autoras, que a registraram, por

\footnotetext{
${ }^{449}$ FERREIRA, Sérgio de Andréa. Pareceres. In Revista Forense nº 371, p. 269.

${ }^{450}$ BARBOSA, Denis. Proteção das marcas... Op. cit. p. 113.
} 
primeiro, há mais de vinte anos, quando a designação não poderia ser considerada comum ou usual". 451

Em linha diferente, mas concluindo da mesma forma, o TRF da $2^{\mathrm{a}}$ Região já impediu a vulgarização da marca BRT, opinando que somente a lei pode constituir ou desconstituir registros de marca. Interpretou a turma julgadora que "[E]ntender que a vulgarização da marca, em plena vigência, poderia ter o condão de subtrair os efeitos do próprio registro, equivaleria a negar vigência à própria lei, quando confere ao registro marcário vigente a proteção de uso com exclusividade". ${ }^{4} 2$

$\mathrm{O}$ registro de marca considerada vulgarizada, ao se tornar o nome comum do produto ou serviço que é designado, torna-se ineficaz. Muito tem se discutido sobre os resultados jurídicos de uma vulgarização sobre um registro previamente constituído. Em caso emblemático decidido pelo TRF da $2^{\mathrm{a}}$ Região, os Desembargadores Federais MESSOD AZULAY, LILIANE RORIZ e ANDRÉ FONTES debateram a natureza jurídica de uma decisão de vulgarização da marca AROMATERAPIA. ${ }^{453} \mathrm{O}$ resultado final foi de que impossível a nulidade dos efeitos do registro, pois no momento de sua concessão, o mesmo era revestido de suficiente distintividade e ele não poderia deixar de existir por um fator superveniente.

A doutrina segue esse entendimento nas palavras de CHAVANNE e BURST ao comentar que " $[u] m$ termo que era suficientemente original quando de seu depósito não perde esta característica sob pretexto de que o público adquiriu o hábito de designar o produto utilizando a marca". ${ }^{454}$

Contudo, há tentativas de normatização dos efeitos de um processo de vulgarização de uma marca, as quais tentam explicar o que acontece com os registros de marca transformados em elementos de uso comum, ou seja, pertencentes ao domínio comum.

\footnotetext{
${ }^{451}$ TJSP. $5^{\text {a }}$ Câmara de Direito Privado. Ap. Civ. 105.949.4/0-00. Rel. Desembargador Marcus Andrade. Julgado em 19/10/2000.

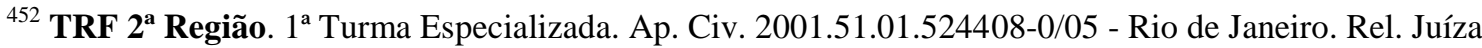
Conv. Márcia Helena Nunes. Julgado em 23/11/2005.

${ }^{453}$ TRF 2 $2^{\text {a }}$ Região. $2^{\text {a }}$ Turma Especializada. Ap. Civ. 2003.51.01.530644-5 - Rio de Janeiro. Rel. Des. Federal Messod Azulay Neto. Julgado em 31.03.2009.

${ }^{454}$ CHAVANNE e BURST. Op. cit. pp. 273/274.
} 
A teoria negativista, em resumo, defende que o registro de marca vulgarizada é mantido, mesmo que ineficaz, diante da impossibilidade de cumprir sua função distintiva. Não há dúvida, atualmente, que tal teoria não pode ser mais aplicada, pois inevitável afirmar que a vulgarização da marca causa efeitos jurídicos à proteção emanada do registro concedido ao seu titular. CHAVANNE e BURST afirmaram que a perda da propriedade por seu sucesso, independentemente da atuação do seu titular seria parodoxal e injusta. ${ }^{455}$

As teorias subjetiva e objetiva comungam da mesma opinião sobre os efeitos da vulgarização no registro de marca. Todavia, elas se separam quando a teoria subjetiva afirma que a degenerescência da marca ocorre com a omissão do titular da marca, e a teoria objetiva dispõe que a vulgarização ocorre com a evolução da linguagem e da expressão pelos povos. Críticas às duas teorias existem, sendo que a do abandono pelo titular parece a mais sensível. Como SCHMIDT bem lembrou, a renúncia ou abandono de um registro de marca não torna a marca uma res communis omnium, mas sim uma res nullius, que pode ser adquirida por qualquer um, inclusive o próprio titular. ${ }^{456} \mathrm{Ou}$ seja, esse resultado jurídico não se justifica.

A teoria mista tenta conjugar todos os cenários, colocando o signo à prova de todas as utilizações e reações do seu titular. Em síntese, a teoria defende que a marca só restará vulgarizada quando consumidores, concorrentes e titulares estiverem utilizando o signo em seu significado semântico, e não marcário. Essa teoria é defendida por boa parte da doutrina.

Diferentemente da legislação internacional $^{457}$, a lei brasileira não trata da possibilidade de perda da eficácia de um registro pela vulgarização de seu signo. Em uma leitura muito abrangente, poder-se-ia interpretar que a causa de extinção do registro pela falta de uso, objeto do artigo 142 da LPI, poderia ser também utilizada para justificar que há abandono tácito pelo titular em hipóteses em que a marca esteja sendo utilizada em seu

\footnotetext{
${ }^{455}$ CHAVANNE e BURST. Op. cit. 274.

${ }^{456}$ SCHMIDT. Marcas em semiótica... Op. cit. p. 162.

${ }^{457}$ SCHMIDT. Marcas em semiótica... Op. cit. pp. 175/178: Art. 12 da Diretiva Européia de Marcas 89/104/CEE; artigo 714-6 do Código de Propriedade Industrial francês, artigo 49, 2 do Trademark Act alemão, artigo 46 do Trade Marks Act inglês de 1994, § 1127 do Lanham Act americano, artigo 55.1 da Lei de Marcas espanhola n. 17/2001.
} 
sentido semântico e não, marcário. Entretanto, não se encontra tal interpretação em qualquer lugar da doutrina.

E em virtude dessa omissão, parte da doutrina brasileira tem expressado entendimento de que não existe possibilidade de extinção de um signo por perda de seu poder distintivo supervenientemente à concessão do registro pelo órgão competente. $\mathrm{Ou}$ seja, por essa linha de raciocínio, a vulgarização de um registro de marca no Brasil pode até ser reconhecida, mas não é capaz de extinguir ou tornar ineficaz o registro da marca.

Por outro lado, existem entendimentos entre autores brasileiros de que é possível, sim, que um registro de marca vulgarizada deixe de existir, seja por extinção ou por perda da validade de sua eficácia. SCHMIDT comenta que Antonio RICCI já se posicionou a favor da extinção do registro de marca vulgarizada por falta de uso e alocou assim tal possibilidade na caducidade, objeto dos artigos 142 e 143 da LPI. Conforme exposto por SCHMIDT ${ }^{458}$, Liliane RORIZ se manifestou a favor da perda de validade do registro por perda da sua distintividade ${ }^{459}$. Outros autores como Amanda SIERVI e Gabriel LEONARDOS entendem que o registro da marca vulgarizada é extinto por perda do objeto de acordo com o artigo 1275 , IV, do CC. ${ }^{460}$

De acordo com SCHMIDT, a perda de proteção por posterior vulgarização é compatível com a LPI que dispôs em seu artigo 180 a possibilidade de não considerar como indicação geográfica os nomes geográficos que se tornaram de uso comum, designando produto ou serviço E complementa ao analisar que a LPI precisa ser analisada em conjunto com a Lei $n^{\circ} 9.784 / 99$, a lei que regula o procedimento administrativo na Administração Pública, cujo artigo 52 dispõe que o processo pode ser extinto pelo órgão

\footnotetext{
${ }^{458}$ Cf. SCHMIDT. Marcas em semiótica... Op. cit. p. 182. apud SIERVI, Amanda Fonseca de. Efeitos da notoriedade em relação à distintividade marcária: secondary meaning e degeneração. Dissertação de Mestrado em Direito Comercial. PUC-SP: São Paulo, 2005. E LEONARDOS, Gabriel. Jurisprudência comentada: o reconhecimento incidental de nulidade de registro de marca. In: RABPI, v. 35, p. 48/51, jul/ago 1998.

${ }^{459}$ SCHMIDT. Marcas em semiótica... Op. cit. p. 181. Apud RICCI, Antonio Ferro. O significado secundário da marca. In: XXVI Seminário Nacional da Propriedade Intelectual da ABPI. Anais 2006. p. 197. E RORIZ, Liliane. A distintividade como função dinâmica da marca. In: XXVI Seminário Nacional da Propriedade Intelectual da ABPI. Anais 2006. p. 185.

${ }^{460}$ Art. 1.275 CC. "Além das causas consideradas neste Código, perde-se a propriedade: (...) IV - por perecimento da coisa”;
} 
competente quando exaurida sua finalidade ou o objeto da decisão se tornar impossível, inútil ou prejudicado por fato superveniente. ${ }^{461}$

Os comentários são pertinentes, pois não faz sentido a lei permitir que um bem, mesmo após sua integridade ter sido abalada e esvaziada e que seja incapaz de cumprir com suas funções, se mantenha intacto. Nada sustentaria um registro de marca vulgarizada já que nada justificaria a existência de um registro que não serve para nada. A marca vulgarizada não distingue, não exclui o seu uso por terceiros, não gera direitos de propriedade perante terceiros, não agrega valor ao seu titular enquanto bem intelectual, porque simplesmente deixou de ser marca para se tornar um elemento de uso comum, possível de ser utilizado por todos sem causar qualquer prejuízo ao titular do registro de marca vulgarizada.

Na visão de SCHMIDT, atribuir tutela jurídica a uma marca vulgarizada é pactuar com o abuso de um direito que já perdeu sua razão de existir. A ausência de menção expressa na LPI não é empecilho a essa solução. ${ }^{462}$ Se a integridade de um bem se esvai, como estatuído pelo CC, o bem deixa de existir por impossibilidade de cumprimento de suas funções. No caso da marca vulgarizada, sua integridade material é vazia pois a marca tendo se transformado em elemento comum, deixa de distinguir seu titular dos demais, perecendo a mais importante função de um sinal distintivo.

Um fenômeno lingüístico não muito comum e influenciado pelo uso da marca por seu titular, impulsionado pela vontade de restabelecer a integridade de seu signo, é o da regeneração de um elemento vulgarizado. SCHMIDT, citando MILLER e DAVIS, aponta para o caso americano da marca SINGER, cuja vulgarização foi determinada em decisão de 1896. Após quase 60 anos da decisão judicial, período no qual os concorrentes deixaram de utilizar o signo vulgarizado e passaram a marcar seus produtos com outros sinais distintivos, a marca SINGER voltou a ser considerada distintiva por tribunal americano. ${ }^{463}$

\footnotetext{
${ }^{461}$ SCHMIDT. Marcas em semiótica... Op. cit. pp. 184/185.

${ }^{462}$ SCHMIDT. Marcas em semiótica... Op. cit. p. 200.

${ }^{463}$ MILLER, Arthur R.; Davis, Michael H. Intellectual property: patents, trademarks and copyright in a nutshell. 2a ed. St. Paul (EUA): West Publishing, 1990, p. 170, apud SCHMIDT, Lélio Denicoli. Marcas em semiótica... Op. cit. p. 158.
} 
No Brasil, o mesmo processo de regeneração de marca vulgarizada está sendo implementado pelo titular da marca CATUPIRY, que já foi interpretada pelo Judiciário brasileiro como elemento vulgarizado em relação a requeijão cremoso, e hoje seu titular tenta recolocá-la como uma marca plenamente distintiva, utilizando-se de ferramentas de marketing, comunicação e principalmente, de conscientização de comerciantes nas principais cidades brasileiras, conforme a notícia publicada no Jornal Valor Econômico. ${ }^{464}$

\subsubsection{A distinção}

Como já explicitado anteriormente, a proposta do presente trabalho sobre a preferência de utilização da denominação distinção para explicar a necessária distância distintiva que uma marca precisa guardar em relação às demais em seu ramo de atuação, serve meramente para diferenciar as distintividades intrínseca e extrínseca de uma marca.

A distintividade intrínseca é de caráter formativo da palavra, expressão ou imagem por si só, as quais precisam distinguir produtos ou serviços, sem descrevê-los ou significar os mesmos. A distintividade, como simples denominação dessa capacidade, é objeto em nosso ordenamento pelo artigo 124, inciso VI da LPI, e não depende da comparação com outros sinais previamente registrados ou solicitados ao órgão competente, para verificar sua disponibilidade na base de dados do INPI.

A distinção, portanto, entre os dois institutos, torna-se mais clara quando afirma-se que a distintividade é a capacidade de um sinal em distinguir os produtos ou serviços. E a distinção é a capacidade de um signo guardar distância distintiva necessária em relação a outros de origem diversa e ser considerado registrável. A distintividade rege a relação entre o sinal e o produto ou serviço. E a distinção rege a relação entre o sinal e os demais de origem diversa.

\footnotetext{
${ }^{464}$ Cf. Valor Econômico de 10 de junho de 2010, página B7: Título: Catupiry aumenta capacidade em 30\%: “(...) Nas pizzarias, a Catupiry continua com a campanha para coibir o uso impróprio de sua marca. Muitos estabelecimentos colocam o nome Catupiry no cardápio, mas usam outro queijo: 'Só nos últimos oito meses, conseguimos reverter mais de 700 pizzarias, que antes usavam qualquer marca e agora adotaram a Catupiry, a maioria delas sem ação judicial", diz o executivo (Francisco Protta, gerente comercial). Agora, a companhia prepara uma página em seu site em que listará as pizzarias que realmente usam Catupiry em suas pizzas. 'Funcionará como uma espécie de programa de fidelização para o consumidor de pizzas', explica Protta”.
} 
A distinção, dessa forma, constitui elemento relevante para a determinação da integridade material da marca, pois contribui para a análise da inteireza de sua capacidade diferenciadora perante terceiros. Parece claro, a essa altura, que quanto maior a distintividade do sinal, maior será o seu poder de se distinguir de marcas de concorrentes, e consequentemente, mais íntegra materialmente, será a marca. E economicamente, a distintividade oferece maiores vantagens aos agentes econômicos na hora da comparação com sinais de terceiros. Assim, uma marca arbitrária ou fantasiosa, em princípio, é mais vantajosa no sentido de diferenciação perante o mercado do que as marcas sugestivas que evocam qualidades ou características dos produtos ou serviços designados.

Na mesma linha, a integridade material das marcas pode ser considerada menor caso hajam marcas parecidas umas com as outras em uma determinada área de atividade. $\mathrm{E}$ se essa convivência for permitida, seja por erro ou por entendimento flexível do órgão registral, menor será a capacidade dessas marcas de impedir o uso de marcas de terceiros que se aproximem.

Dessa forma, a distinção é tutelada por nosso ordenamento com carga negativa $^{465}$ já que a LPI não dispõe de dispositivo definindo o referido instituto, mas ao contrário, veda expressamente em seu art. 124, inciso XIX $^{466}$ que determinada marca seja registrada quando esta puder ensejar confusão ou associação com marca alheia.

\subsubsection{A obtenção de exclusividade}

A distinção de uma marca é alcançada quando o requisito da novidade relativa é cumprido. E a análise desse requisito se dá através do processo comparativo entre duas marcas de titulares diferentes. Alguns elementos são levados em consideração: (a) anterioridade da concessão do registro de uma das marcas; (b) similitude entre as marcas; (c) identidade ou semelhança entre os produtos ou serviços designados por ambas as marcas; (d) existência de risco de confusão ou associação perante o mercado.

\footnotetext{
${ }^{465}$ GAMA CERQUEIRA. Tratado... Op. cit. Vol. II, Tomo II. p. 123. "O direito de uso exclusivo da marca importa, como corolário, o direito de impedir que terceiros empreguem marca idêntica ou semelhante, sendo esses direitos limitados nos termos do art. 95, $n^{\circ} 17$, que visa a impedir a confusão entre os produtos, levando em conta a sua congenericidade e a semelhança das marcas que os assinalam ”.
}

${ }^{466}$ Art. 124, XIX LPI. Vide nota 53. 
A ideia de se impor tais comparações tem o condão primeiro de proteger a integridade material de uma das marcas e o investimento despendido por seu agente econômico que envidou esforços para que seu signo fosse respeitado e que o mesmo mantivesse a integridade material inabalada. Outra consequência da proteção à integridade material é a manutenção do seu brilho de modo que o consumidor não confunda ou associe a origem de sua escolha com outra diversa, e assim ocorra ato ilícito de desvio de clientela $^{467}$.

De acordo com Clóvis da Costa RODRIGUES, experimentar-se-á confusão entre duas fontes dentro de um mesmo segmento mercadológico "[q]uando não podemos reconhecer as distinções, as diferenças; quando as coisas se tomam umas pelas outras; quando se misturam umas com as outras". 468

O consumidor, ao contrário do que possa parecer, não é atento e a simples identidade de elementos distintivos pode ser suficiente para causar confusão aos consumidores, como é bem explicado por Celso DELMANTO quando afirma que "[I] sto é o que se chama capacidade de distinguir por elementos que os consumidores menos precavidos (unwary purchasers) guardam na memória, numa forma de associação mecânica de ideias". ${ }^{469}$

Sobre a possibilidade de confusão entre marcas, GAMA CERQUEIRA oferece valiosa lição ao dizer que "[O] que se deve verificar é, exclusivamente, se a marca se destina a produto idêntico ou semelhante, ou pertence ao mesmo gênero de comércio ou indústria ou gênero afim. É indiferente, indagar, também, se o pretendente ao registro age de boa ou má-fé, porque a lei, nesta parte, não trata do delito de reprodução, mas

\footnotetext{
${ }^{467}$ O desvio de clientela pela imitação ou reprodução indevida de sinais distintivos, na visão de Cláudio BARBOSA, ocorre nas situações em que o consumidor pretende realizar o ato A, mas inconscientemente realiza o ato B. A informação é apenas uma instrumentalidade adicional a ser utilizada par estabelecer a racionalidade das situações que envolvem sinais distintivos. In BARBOSA, Cláudio. Op. cit. pp. 152/153.

${ }^{468}$ RODRIGUES, Clóvis Costa. Concorrência desleal, Rio de Janeiro: Peixoto, 1945. p. 136.

${ }^{469}$ DELMANTO, Celso. Concorrência Desleal. Bushatsky, Edusp, 1975. pp. 85/86. Continua o autor lecionando que "[Q]uase nunca o desencaminhador faz uma cópia exata ou imitação servil, freqüentemente deixando, a propósito, algumas diferenças que lhe servirão para alegar, mais tarde, que não copiou. Como chama os autores italianos, é aquela riproduzione studiatamente diversa. São usados símbolos que, por sua semelhança com os do concorrente, podem facilmente ingenerare equivoco. A imitação não é feita para copiar, mas sim, especialmente para enganar - calculated to deceive. (...) O que se imita é o aspecto extrínseco, a aparência formal do artigo ou produto, ou seja, a sua característica exterior: aquilo que o comprador vê e tem na recordação".
} 
simplesmente das causas que impedem o registro. Desde que a marca reproduza outra anteriormente registrada, o registro deve ser recusado", ${ }^{470}$

Diversos são os modos de obter ilicitamente a clientela de outrem, mas nas próximas linhas, limitar-se-á a discutir a integridade material da marca sob o ponto de vista da sua distinção.

\subsubsection{A marca ordinária}

A marca registrada ordinária é resultado da análise do artigo 122 da LPI, ou seja, o sinal distintivo visualmente perceptivo e não compreendido nas proibições legais. Isso significa dizer que a marca ordinária é aquela capaz de distinguir seus produtos ou serviços e capaz de diferenciar seu agente econômico dos demais; e sua proteção é limitada à área de atuação de seu titular, e aquelas que guardem relacionamento ou afinidade com a determinada área de atividade.

Para que uma marca registrada seja considerada ordinária, a mesma precisa ter sido objeto de procedimento administrativo conduzido pelo INPI, como já explicitado, e teve que atender aos preceitos dos artigos 123, 124 e 128 da LPI. O artigo 124, inciso XIX da referida lei é o que limita o direito de uso exclusivo sobre uma marca ordinária.

Analisando-se bem o art. 124, inciso XIX da LPI, confirma-se que o requisito de novidade relativa precisa ser cumprido. Para ser considerada registrável, a marca em teste não pode constituir reprodução ou imitação, no todo ou em parte, ainda que com acréscimo, de marca alheia registrada, para distinguir ou certificar produto ou serviço idêntico, semelhante ou afim, suscetível de causar confusão ou associação com marca alheia.

A marca ordinária, portanto, é distintiva per se, distinta das que já foram registadas por concorrentes, e sua distinção é limitada à sua área de atuação e adjacentes. O princípio da especialidade já foi alvo de estudo no capítulo sobre os direitos sobre as

${ }^{470}$ GAMA CERQUEIRA. Tratado... Op. cit . vol II, pp. 910/911. 
marcas e suas limitações, mas não custa trazer mais duas passagens doutrinárias, nesse sentido.

A primeira é trazida por Denis BARBOSA, que lembra que "[u]m dos princípios básicos do sistema marcário é o da especialidade da proteção: a exclusividade de um signo se esgota nas fronteiras do gênero de atividades que ele designa. Assim se radica a marca registrada na concorrência: é nos limites que a propriedade se constrói", 471

A outra é de GAMA CERQUEIRA que ensina que as marcas podem ser idênticas ou semelhantes uma à outra, desde que "[u]sada para distinguir produtos diferentes ou empregada em outro gênero de comércio ou indústria. É neste caso que o Princípio da Especialidade das Marcas tem sua maior aplicação, abrandando a regra relativa à novidade. A marca deve ser nova, diferente das já existentes; mas, tratando-se de produtos ou indústrias diversos, não importa que ela seja idêntica ou semelhante a outra em uso". ${ }^{472}$

Conforme ensinamento da melhor doutrina, as marcas devem ser analisadas a partir de seu conjunto, sendo inaceitável a separação ou divisão de seus elementos. Clóvis da Costa RODRIGUES, citando as decisões do CPI/45., ensinava que "b) De mais a mais em se tratando de examinar se uma marca imita outra, devem as duas ser apreciadas, conforme a impressão de conjunto deixada no observador. Um ou outro elemento isolado da marca não influe, se se encontra bastantemente diferenciada a impressão do conjunto. ${ }^{473}$ c) A marca dessa recorrente $n^{\circ} 25.545$, de 1928 , cuja cópia se anexa, é complexa, formada pelos vários elementos ali descritos, constituindo um conjunto, do qual não pode sua propriedade destacar qualquer dos elementos que o constituem, e elegê-lo, a seu critério, como sendo o elemento essencial e característico de sua marca; quando, em verdade, o que a deve caracterizar é a fisionomia do conjunto, o seu aspecto geral, jamais esse ou aquele dos seus elementos componentes considerados isoladamente". ${ }^{474}$

\footnotetext{
${ }^{471}$ BARBOSA, Denis Borges. Uma Introdução... p. 835.

${ }^{472}$ CERQUEIRA. Tratado... Op. cit. Vol.I, p. 370.

${ }^{473}$ RODRIGUES, Clóvis da Costa. Op. cit. p. 201. Acórdão no 256, termo 28.755.

${ }^{474}$ RODRIGUES, Clóvis da Costa. Op. cit. p. 201. Acórdão no 872, termo 34.183.
} 
Como dizia Maurice MERLEAU-PONTY, ao interpretar a forma de análise entre dois objetos, "[N]ão percebemos de início as folhas, depois a árvore; não ouvimos inicialmente as notas, depois a melodia; é o conjunto da árvore ou de melodia que é inicialmente percebida; e é nele que aprendemos a distinguir folhas ou notas". ${ }^{475}$

\subsubsection{A marca notoriamente conhecida}

Diferentemente do já apresentado no Capítulo IV sobre a marca notoriamente conhecida como exceção ao princípio da territorialidade, o condão aqui é diferente. A notoriedade da marca em seu ramo de atividade denota-se como o primeiro passo distintivo à frente da marca ordinária, fazendo crescer a integridade material da marca, agora chamada de famosa.

A notoriedade de uma marca é atestada de acordo com as provas trazidas pelos interessados em comprovar tal status. Como bem expressado pelo INPI, a CUP não delimitou que tipo de provas precisam ser apresentadas, mas como prática, os titulares de marcas famosas colecionam documentos que demonstrem reconhecimento pelo público consumidor como peças publicitárias, pesquisas de opinião, resultados de vendas, posicionamento no mercado etc. Douglas Gabriel DOMINGUES, tentando entender as diferenças entre os institutos da marca notoriamente conhecida e a marca de alto renome, expressou que a marca notória objeto do artigo 67 do CPI, deveria “(...)[a]presentar as seguintes características: originalidade, constância, produção elevada e venda em escala nacional ou mundial", 476

Nessa mesma linha de raciocínio, nossos tribunais já decidiram que "[O] juiz não pode substituir o povo na outorga da fama de uma marca, e dizer por conhecimento próprio e pessoal que uma marca é ou não famosa, seja porque é a própria discussão integrante do thema decidendum submetido ao Judiciário mediante o devido processo legal a exigir fundamentação que não seja a vetusta "verdade sabida", seja porque a fama não é fato notório". 477

\footnotetext{
${ }^{475}$ MERLEAU- PONTY, Phénoménologie de la Perception. Paris: Gallimard, 1945. p.46.

${ }^{476}$ DOMINGUES, Douglas Gabriel. Op. cit. p. 453.

${ }^{477}$ TRF 2 $^{\mathbf{a}}$ Região. Ap. Cível n ${ }^{\circ}$ 93.02.19483-3. Rel. Des. André Fontes. Julgado em 23 de agosto de 2005. DJU de 02 de agosto de 2007.
} 
Saliente-se que a marca pode ser desconhecida do grande público. Importante é a notoriedade em seu ramo de atividade e no país onde ocorra o questionamento do referido status. Por exemplo, tome-se uma determinada marca que, embora a população geral desconheça, identifica componentes de maquinários agrícolas, detendo um terço da produção européia e largamente exportada para o Brasil. Neste caso, a marca será notoriamente conhecida aqui mesmo que não tenha sido registrada pela empresa européia no Brasil, e em princípio, não poderá ser registrada nem usada por terceiros, tudo de acordo com o artigo 6 bis da CUP e artigo 126 da LPI, ambos já citados e transcritos.

Aos olhos da doutrina, a infração à marca notoriamente conhecida "[n] ão se limita, apenas, a destruir a reputação do produto: tem conseqüências muito mais danosas quando chega, por vezes, a comprometer o prestígio e o crédito de uma indústria. Em outras palavras, objetivemos o caso: certa empresa adota para seus produtos determinada marca que se torna notória e expectável, desfrutando a preferência de larga clientela. Terceiros, seduzidos por esta circunstância e pretendendo ocultar-se à sombra desse prestígio para dele usufruir vantagens, introduzem no mercado artigos diferentes, mas identicamente marcados. Não tardará que a freguesia, conhecendo a marca, passe a adquirir, também, os artigos do novo concorrente na ingênua ilusão de procederem do mesmo fabricante. ... Tais manobras são comuníssimas no tráfico do comércio moderno". 478

A aplicação do artigo 6 bis da CUP já abrigou discussões e até mesmo questionamentos da sua eficácia, mesmo tendo o Brasil aderido à Convenção desde a sua fundação. Em 1991, o INPI enfrentou o assunto ao emitir o Parecer nº 091, no qual dirimiu as dúvidas da aplicação do referido dispositivo legal introduzido na legislação brasileira pelo Decreto 75.752/75, ao reconhecer que "a) não há e nem poderia haver qualquer impedimento na mesma lei interna (Código da Propriedade Industrial) para a aplicação do art.6bis da Convenção da União de Paris; b) como órgão responsável pela aplicação das normas que regulam a Propriedade Industrial e, sendo a Convenção de Paris subscrita pelo Brasil, cabe ao INPI aplicá-la imperativamente; c) as marcas de indústria e de comércio, notórias internacionalmente em um determinado segmento de mercado, têm

\footnotetext{
${ }^{478}$ RODRIGUES, Clóvis da Costa. Op. cit. p. 147.
} 
proteção especial, independente de estarem ou serem elas depositadas ou registradas no Brasil, nos termos do citado dispositivo convencional; d) o INPI está livre para, de ofício, ou por provocação da parte interessada, dentro dos trâmites regulares, recusar ou invalidar o pedido de registro de marca que reproduza ou imite marca notoriamente conhecida em determinado segmento de mercado, desde que se limite aos prazos previstos no CPI."

Com a redação do artigo 126 na LPI, qualquer dúvida sobre a aplicação do

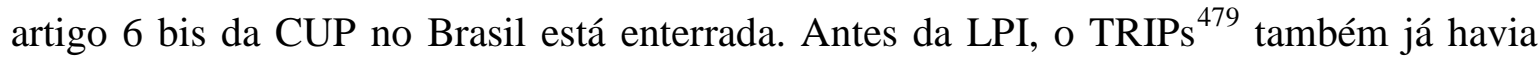
comentado sobre a aplicação do artigo 6 bis da CUP, apenas reforçando a obrigação do país em reconhecer a proteção especial que trata tal artigo. Seu fundamento é histórico, pois desde 1883, o interesse internacional era o de salvaguardar a livre circulação de mercadorias entre os países, respeitando-se a Propriedade Intelectual dos titulares.

No que diz respeito ao território de obtenção dessas provas, o INPI segue a linha de pensamento de BODENHAUSEN, então secretário geral do BIRPI, que assim se expressou: “[A] provisão sob exame, contudo, vai além disso quando prevê que, para ser protegida, a marca necessita ser considerada conhecida no País em questão (...)". 480

O entendimento contrário é manifestado por DANNEMANN ao assentir que “(...) [n] otoriedade é conhecimento. O tratado é indiferente à forma pela qual a marca se projeta e, assim, não poderia o intérprete alargá-lo para incluir uma condicionante de sérias consequências". 481

\footnotetext{
${ }^{479}$ Art. 16 TRIPs. "2 - O disposto no art.6 "bis" da Convenção de Paris (1967) aplicar-se-á, "mutatis mutandis", a serviços. Ao determinar se uma marca é notoriamente conhecida, os Membros levarão em consideração o conhecimento da marca no setor pertinente do público, inclusive o conhecimento que tenha sido obtido naquele Membro, como resultado de promoção da marca. 3 - O disposto no art.6 "bis" da Convenção de Paris (1967) aplicar-se-á, "mutatis mutandis", aos bens e serviços que não sejam similares àqueles para os quais uma marca esteja registrada, desde que o uso dessa marca, em relação àqueles bens e serviços, possa indicar uma conexão entre aqueles bens e serviços e o titular da marca registrada e desde que seja provável que esse uso prejudique os interesses do titular da marca registrada".

${ }^{480}$ BODEnhausen, G. H. C, Guide to the Application of the Paris Convention for the Protection of Industrial Property, BIRPI 1969, WIPO Reprinted 2004, p. 92. Tradução livre do original: "The provision under examination, however, goes further than that when it states that, in order to be protected, the mark must be considered well known in the country concerned (...)”. No mesmo sentido, DOMINGUES, Douglas Gabriel. Op. cit. p. 454. "O INPI (...) considera a questão observando se a marca possui certo renome ou fama, no Brasil, dentro do ramo de atividade".
}

${ }^{481}$ DANNEMANN. Op. cit. p. 243. 


\subsubsection{A marca de alto renome}

\subsection{Considerações gerais e históricas}

A marca de alto renome é protegida em todas as áreas de atividade. É preciso haver um cuidado especial com a integridade material dessas marcas, pois há risco de prejuízos graves aos titulares em virtude dos altos investimentos que fizeram e fazem em suas marcas.

Assim, o mais alto nível de distintividade extrínseca que um signo pode alcançar no Brasil é o de marca de alto renome, que é munida de alto grau de integridade material, tudo de acordo com o artigo 125 da LPI. Nota-se assim que a integridade material da marca de alto renome merece atenção especial dos julgadores e de eventuais infratores, pois é de se aplicar penas e multas sejam mais severas do que em infrações às marcas ordinárias.

Mas, o início dessa história está em 1964, quando o arcabouço jurídico brasileiro recebeu a novidade do instituto da marca notória pelas mãos de Luiz Leonardos, Julio Mello e Carlos Henrique de Carvalho Fróes, quando o projeto apresentado ao IASP foi aprovado. A intenção primeira do projeto era a de proteger as marcas famosas de serem registradas injustamente por terceiros ou de serem utilizadas indevidamente, contribuindo para confusão quanto à origem da marca notória ou prejuízo para a reputação da marca, ou ainda enfraquecimento de seu caráter distintivo ou do seu poder atrativo da marca. ${ }^{482}$

Alguns anos depois, o CPI de 1971 instituiu a marca notória em seu texto legislativo. O artigo 67 do código estatuía que marca registrada considerada notória no Brasil, teria proteção especial assegurada em todas as classes, mantido registro próprio para impedir o de outra que a reproduza ou imite, no todo ou em parte, desde que haja possibilidade de confusão quanto à origem dos produtos, mercadorias ou serviços, ou ainda prejuízo para a reputação da marca.

Mas, o que é notório?

${ }^{482}$ SOARES, José Carlos Tinoco. Marcas notoriamente conhecidas - Marcas de alto renome vs. Diluição. Rio de Janeiro: Lumen Juris, 2010. p. 199. 
Conceitualmente, notório é o fato que não precisa de prova para ser reconhecido. $\mathrm{O}$ entendimento é manifestado pelo artigo 334 do $\mathrm{CPC}{ }^{483}$ Apoiado nesse conceito, é que se explica o que vem a ser uma marca notória como era conhecida a marca de alto renome sob a égide do CPI. Desta feita, a marca notória é tão famosa que, em tese, não haveria necessidade de se compilar provas para a aceitação desse status.

Todavia, um mínimo de formalismo se faz necessário para que o sistema tivesse segurança jurídica suficiente, de modo a que as marcas candidatas ao status de marca notória pudessem ser caracterizadas como tais, diminuindo as chances de reversão das decisões sejam do INPI ou do Judiciário.

Note-se que, diante do imposto pelo artigo 67 do CPI, o registro de marca notória era próprio, ou seja, um procedimento autônomo no qual regras foram impostas pelo Ato Normativo $n^{\circ} 46 / 1980$, o qual dispôs sobre as informações que deveriam ser confirmadas para que as marcas candidatas fossem reconhecidas como marcas notórias. Alguns requisitos eram: (a) reconhecimento pelo público; (b) local e abrangência territorial do uso da marca; (c) provas de divulgação da marca; (d) pesquisa de opinião que demonstrasse a fama da marca junto ao público.

Não há dúvida de que tais requisitos trariam condições um pouco mais objetivas para a interpretação de um valor que é subjetivo por sua natureza: a fama.

Com o passar do tempo, o legislador entendeu por bem diminuir as confusões terminológicas da palavra notório, tendo em vista as interpretações históricas das expressões marcas notoriamente conhecidas e marcas notórias. Ambas são bem distintas, mas o emprego equivocado de ambas fez nascer esse propósito.

A LPI, portanto, alterou a nomenclatura das marcas famosas que merecem proteção especial em todas as áreas de atividade, para marca de alto renome. O artigo 125 da LPI traz definição básica sobre o instituto ao expor que "[Ả] marca registrada no

${ }^{483}$ Art. 334 CPC. "Não dependem de prova os fatos: I-notórios"; 
Brasil considerada de alto renome será assegurada proteção especial, em todos os ramos de atividade".

Em virtude da conceituação acima e pela inexistência de legislação definidora dos aspectos e requisitos para o reconhecimento do alto renome, os titulares das antigas marcas notórias quedaram-se órfãos pois, embasados no artigo 125 da LPI, não sabiam o que fazer para continuarem a proteger suas marcas famosas. Assim, apoiados na intenção da Ementa Substitutiva n ${ }^{\circ}$ 310/92 ao Projeto de Lei no 824-B, de 1991 (que veio a se tornar a LPI em 1996), tentava estabelecer que o alto renome seria arguído por impugnações, oposições ou recursos. Nascia assim a tentativa de reconhecimento desse status pela via incidental já que o registro próprio do CPI estaria banido.

Entre a promulgação da LPI e a criação pelo INPI de um ato administrativo que normativasse o reconhecimento do alto renome, a autarquia passou a estocar processos de pedidos de marca que sofriam ataques administrativos embasados no alto renome. Sem resposta da autarquia, os titulares passaram a procurar o Judiciário para dirimir suas controvérsias. E através de ações declaratórias, os titulares das marcas DAKOTA ${ }^{484}$, ABSOLUT $^{485}$, CASTROL $^{486}$, CONTINI $^{487}$, TIGRE $^{488}$, SANTA MARINA ${ }^{489}$ e BOM BRIL $^{490}$ tentaram obter o reconhecimento de alto renome das mesmas.

\footnotetext{
${ }^{484}$ TRF 2 ${ }^{a}$ Região. Ap. Cív. no 1999.02.01.041882-1. Quinta Turma. Rel. Des. Raldênio Bonifacio Costa. Julgado em 19/12/2001. Inicialmente, a marca DAKOTA foi reconhecida como sendo de alto renome pelo Juízo da $22^{\mathrm{a}}$ Vara Federal do Rio de Janeiro e mantida pela decisão supra. Todavia, o INPI impetrou ação rescisória para desconstituir o acórdão. Como resultado, o TRF da $2^{\mathrm{a}}$ Região entendeu que o Judiciário invadiu competência do INPI, e não poderia ter reconhecido o alto renome da marca DAKOTA.

${ }^{485}$ JFRJ. Ação $n^{\circ}$ 0530031-06.2002.4.02.5101. Número antigo: 2002.51.01.530031-1. Juízo da $25^{\text {a }}$ Vara Federal/RJ. Juiz Guilherme Bollorini Pereira. Publicado no DOE do dia 06/10/2005. Após o reconhecimento judicial do alto renome da marca ABSOLUT, o INPI impetrou a ação rescisória no 2007.02.01.013373-4, que culminou com a procedência da ação que desconstruiu o alto renome da marca.

${ }^{486}$ TRF 2 ${ }^{\mathbf{a}}$ Região. Ap. Cív. no 2002.51.01.514661-9. Primeira Turma Especializada. Rel. Juiza Conv. Marcia Helena Nunes. O tribunal decidiu que o reconhecimento de alto renome é uma questão de fato, e não poderia se dar de forma abstrata através de ação declaratória, mas através de procedimento especial administrado pelo INPI.

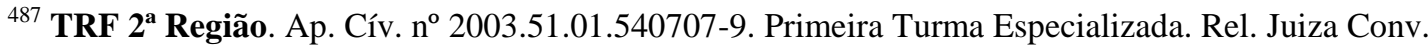
Marcia Helena Nunes. Julgado em 12/08/2008. A decisão seguiu a mesma orientação do caso CASTROL.

${ }^{488}$ TRF 2 ${ }^{\mathbf{a}}$ Região. Ap. Cív. no 2006.51.01.504829-9. Primeira Turma Especializada. Rel. Des. Fed. Aluisio Goncalves De Castro Mendes. A decisão seguiu a mesma orientação dos casos CASTROL e CONTINI.

${ }^{489}$ TRF 2 Região. Ap. Cív. no 96.02.41312-3. Segunda Turma Especializada. Rel. Des. Fed. André Fontes. Julgado em 26/06/2007. A decisão seguiu a mesma orientação dos casos CASTROL, CONTINI e TIGRE.

${ }^{490}$ TRF 2 Região. Ap. Cív. no 2003.51.01.505840-1. Segunda Turma Especializada. Rel. Des. Fed. Messod Azulay Neto. Julgado em 28/03/2007. A Turma concluiu que o Judiciário não poderia invadir a competência do Poder Executivo. " $V$ - Vê-se, pois, que a pretensão autoral não é de natureza declaratória, mas constitutiva - aquisição de um novo status para marca BOMBRIL, com base em conceito inaugural (de alto
} 
Entretanto, nem os juízes ou o INPI levaram em consideração que os efeitos de uma sentença declaratória ou a competência para o reconhecimento do alto renome. De um lado, sentenças judiciais não sofrem limites temporários e assim, mediante tais sentenças, as marcas seriam consideradas de alto renome ad eternum. Imagine-se se uma dessas titulares viesse à falência ou, se uma decisão das empresas marcas de alto renome fossem abandonadas. Seu status persistiria? Do outro lado, no desenrolar das ações declaratórias, o INPI emitiu a Resolução no 110/2004, e depois a Resolução nº 121/05.

Assim o Poder Judiciário passou a se manifestar sobre a sua incompetência tendo em vista regulamento próprio para o processo de reconhecimento de alto renome ${ }^{491}$.

Como resultado, o INPI ajuizou ações rescisórias contra as sentenças declaratórias que reconheceram as marcas acima como sendo de alto renome, saindo-se vencedor nas ações contra o reconhecimento das marcas DAKOTA e ABSOLUT. Há outras demandas decididas pelo TRF da $2^{\text {a }}$ Região e suas decisões têm se distinguido de acordo com os procedimentos administrativos do INPI. Ou seja, aquelas marcas que já foram reconhecidas como de alto renome pela autarquia tem obtido guarida judicial. E as que não foram reconhecidas, o tribunal tem se manifestado contrário ao reconhecimento em virtude do rito especial determinado pela Resolução INPI nº 121/05.

A Resolução INPI $n^{\circ}$ 121/05, portanto, trata da possibilidade de titulares de marcas famosas de reivindicar o reconhecimento do alto renome através de medidas incidentais, tais como oposições e nulidades administrativas. Mais uma vez, diferentemente do sistema anterior, o titular da marca de alto renome precisará se insurgir contra pedidos ou registros de marca que, em tese, contrariam seus interesses.

\footnotetext{
renome) - matéria que não se coaduna com a via eleita sob pena de desvirtuamento da prestação jurisdicional e confusão de competência, não podendo o judiciário se prestar à consagração de tais vícios". 491 “O alto renome de uma marca é situação de fato que decorre do amplo reconhecimento que o signo distintivo goza junto ao público consumidor, motivo pelo qual não pode o juiz substituir o povo no seu pensamento e impressão e declarar, de modo permanente e irrestrito, a sua fama. II - É tarefa da justificação (art. 861 do Código de Processo Civil) e não da declaração judicial (art. $4^{\circ}$ do Código de Processo Civil) a de documentar a existência de fato para utilização futura".
} 
A Resolução INPI n ${ }^{\circ}$ 121/2005 atribui os requisitos obrigatórios para o reconhecimento do alto renome, exigindo do requerente a apresentação de provas cabíveis, levando elementos informativos, os quais seguem abaixo:

"1. data do início do uso da marca no Brasil;

2. público usuário ou potencial usuário dos produtos ou serviços a que a marca se aplica;

3. fração do público usuário ou potencial usuário dos produtos ou serviços a que a marca se aplica, essencialmente pela sua tradição e qualificação no mercado, mediante pesquisa de opinião ou de mercado ou por qualquer outro meio hábil;

4. fração do público usuário de outros segmentos de mercado que, imediata e espontaneamente, identifica a marca com os produtos ou serviços a que ela se aplica, mediante pesquisa de opinião ou de mercado ou por qualquer outro meio hábil;

5. fração do público usuário de outros segmentos de mercado que, imediata e espontaneamente, identifica a marca essencialmente pela sua tradição $e$ qualificação no mercado, mediante pesquisa de opinião ou de mercado ou por qualquer outro meio hábil;

6. meios de comercialização da marca no Brasil;

7. amplitude geográfica da comercialização efetiva da marca no Brasil e, eventualmente, no exterior;

8. extensão temporal do uso efetivo da marca no mercado nacional e, eventualmente, no mercado internacional;

9. meios de divulgação da marca no Brasil e, eventualmente, no exterior;

10. extensão temporal da divulgação efetiva da marca no Brasil e, eventualmente, no exterior;

11. valor investido pelo titular em publicidade/propaganda da marca na mídia brasileira nos últimos 3 (três) anos;

12. volume de vendas do produto ou a receita do serviço nos últimos 3 (três) anos;

13. valor econômico da marca no ativo patrimonial da empresa”.

Uma das críticas que o INPI vem sofrendo em relação à Resolução consiste na obrigatoriedade de se arguir o alto renome, mesmo após a primeira decisão de reconhecimento. $\mathrm{Na}$ verdade, como uma constatação de fato, o alto renome precisa ser revisto de tempos em tempos e por isso, o status tem vigência de 5 anos prorrogáveis por iguais períodos desde que medidas de ataques sejam intentadas e os documentos comprobatórios do alto renome sejam reanalisados à luz do período investigado.

Há outra crítica ao procedimento de análise do alto renome, mas diz respeito ao alcance das decisões administrativas. É que, via de regra, o INPI se depara com a hipótese de deferimento da marca atacada, tendo em vista a inexistência de risco de confusão com a 
coexistência entre a marca famosa e a atacada. Não seria impossível pensar que o reconhecimento do alto renome não gera efeitos absolutos de indeferimento de pedidos de marca de terceiros. Não parece absurda a possibilidade de haver, ao mesmo tempo, fama e coexistência pacífica.

Do outro lado, DANNEMANN entende que, se não há risco de confusão é porque a marca famosa não merece o status de alto renome. No seu sentir, "[A] possibilidade de confusão ou associação é corolário da própria notoriedade (= alto renome) conquistada pela marca. Se não se verificar associação ou confusão, é que, a rigor, a marca, na verdade, notória não é", 492

Até 2010, essas são as marcas de alto renome reconhecidas pelo INPI $^{493}$ : PIRELLI, HOLLYWOOD, 3M, KIBON, NATURA, MOÇA, DIAMANTE NEGRO, PLAYBOY; VEJA, DERBY, TRAMONTINA, HAVAIANAS, BOM BRIL, ITAÚ, CHICLETS, BIC, SWOOSH DA NIKE, LAND ROVER, O BOTICÁRIO, CHANEL, SADIA e MCDONALD'S.

\subsection{Considerações doutrinárias}

Tinoco SOARES disse que "[O] grau de notoriedade de uma marca é adquirido pela apreciação do público; é o consumidor elou o usuário que fixa, pela sua aceitação, o valor da marca, posto que esta é um sinal que tem por objetivo reunir a clientela, sem a qual nada significa. Sem a aceitação pública e manifesta não existe notoriedade de marca". 494

Denis Borges BARBOSA concorda com autor, e explica seu entendimento citando BURST e CHAVANNE: "[P]ara que haja marca notória, é necessário que o público, ao ouvir o enunciado da marca, tenha o reflexo quase automático de pensar no produto ou serviço que ela representa. (...) Poder-se-ia igualmente perguntar perante que

\footnotetext{
492 DANNEMANN. Op. cit. p. 235.

${ }^{493}$ Lista disponível através do link

http://www.inpi.gov.br/images/stories/downloads/marcas/pdf/alto_renome_em_vigencia.pdf. Acessado em $12 / 12 / 2012$.

${ }^{494}$ SOARES, Tinoco. Tratado da Propriedade Industrial. Vol. I. São Paulo: Resenha Tributária, 1988. pp.388/389.
} 
tipos de consumidor se deve apreciar a notoriedade. Deve-se tratar, ao que entendemos, do grande público, e não só da parte do público que usa o produto marcado". ${ }^{495}$

$\mathrm{Na}$ visão de DANNEMANN, “[A]s marcas notórias são verdadeiros magnetos, aptos a atrair clientela pelo simples fato de sua presença, independentemente dos produtos ou serviços a que se destinavam na origem. Pelo seu valor distintivo muito mais alto, é natural que o direito lhes conceda amparo especial". 496 Tão especial que o CPI de 1971 instituiu que o uso indevido de marca que reproduza ou imite marca notória registrada, constituiria agravante de crime. ${ }^{497}$

De acordo com DANNEMANN, "[A] notoriedade é um fato do qual se irradiam consequências no plano do Direito. Como fato, escapa a toda e qualquer tentativa de fixação no tempo e no espaço (...) Há marcas que perduram, atravessando as décadas, como COCA-COLA, MERCEDES e muitos outros sinais. Outras há que se apagam em poucos anos ou meses ou vão definhando no decorrer das décadas até atingir a decrepitude e não exalar qualquer vestígio da antiga magia". 498

Denis BARBOSA se mostra preocupado com o aproveitamento ilícito de marcas notórias, pois “a ocupação, por terceiros, de uma marca cuja notoriedade foi gerada pelo titular original impede ou dificulta a eventual ampliação futura e mesmo utilização por este do valor econômico criado graças a seu investimento e esforço. Desta forma, não só existe lesão ao fundo de perda de poder evocativo, e até mesmo pela perda material da oportunidade comercial gerada". 499

Vê-se que a doutrina manifesta preocupação adicional à proteção das marcas famosas, tal como acontece no direito americano que protege suas marcas afamadas através do Trademark Anti Dilution Act. Em vista dos altos investimentos e do

\footnotetext{
${ }^{495}$ BARBOSA, Denis Borges: Uma Introdução... Tradução livre do original: "Pour qu'il y ait marque notoire, il est nécessaire que lê public, à énoncé de la marque, ait lê réfléxe quais automatique de penser au produit ou au service qu'elle represente. (...) On peut également se demander auprès de quelles sortes de consommateurs doit s'apprécier la notoriété. Il doit s'agir, à notre avis, du grand publique et non pás de la seule partie du public qui utilize lê produit marqué."

${ }^{496}$ DANNEMANN. Op. cit. p. 236.

${ }^{497}$ Art. 67, § único do CPI.

${ }^{498}$ DANNEMANN. Op. cit. p. 232.

${ }^{499}$ BARBOSA, Denis. Proteção das marcas... Op. cit. p. 138.
} 
reconhecimento notório dessas marcas pelo público, sua integridade material alcança o teto máximo e certamente, a marca de alto renome merece proteção especial.

Um exemplo do tratamento especial à integridade material máxima que a marca de alto renome faz jus é a impossibilidade de se registrar nomes de domínio no Brasil compostos por marcas já reconhecidas pelo INPI como de alto renome. De acordo com a Resolução nº 001/98 do Comitê Gestor da Internet, marcas de alto renome ficam reservadas no estoque do Registro.br a fim de se evitar a possibilidade de utilização indevida de marcas famosas. Para tanto, há dois fundamentos nessa proibição: (a) proteção à integridade material da marca de alto renome; e (b) solução administrativa de desvinculação de nomes de domínio com o princípio da especialidade.

\subsubsection{A diluição da exclusividade}

A apreciação da teoria da diluição passa necessariamente pela interpretação das forças de vontades existentes no mercado, de modo a fomentar a cópia de marcas já reconhecidas em seu nicho mercadológico, seja pela qualidade de seus produtos ou pelas atividades responsáveis da empresa em relação ao processo de produção de determinado produto. Mark BATEY resume esses comentários ao dizer que "o consumo é motivado não só pela utilidade do produto ou serviço, mas também por necessidades emocionais ou relacionadas à afirmação de uma identidade (posição social ou vinculação a grupos, valores e idéias)", 500

Na visão de J. Thomas MCCARTHY, diluição é "[U]m tipo de violação de uma marca forte em que o uso pelo réu, enquanto não causar risco de confusão, ofusca a distinção ou mancha a imagem da marca do autor". ${ }^{501}$ Complementando, o tribunal americano entendeu que “[A]penas marcas 'famosas' são protegidas contra a diluição. Para possuir o poder de venda e reconhecimento protegidos pelas regras anti-diluição, a marca deve ser relativamente forte e famosa". ${ }^{502}$

\footnotetext{
${ }^{500}$ BATEY, Mark. O significado da marca. pp. 39/40 e 201.

${ }^{501}$ MCCARTHY. Op. cit. p. 174. Traduzido livremente de: "[A] type of violation of a strong trademark in which the defendant's use, while not causing a likelihood of confusion, blurs the distinctiveness or tarnishes the image of the palintiff's mark".

${ }^{502}$ MCCARTHY. Op. cit. p. 175. Citando o caso Mead Data Cent. Inc. v. Toyota Motor Sales, Inc. 875 F.2d 1026, 1031, 10 USPQ2d 1961, 1966 (2d Circ. 1989).Traduzido livremente de: “[O]nly 'famous' marks are
} 
Tem-se que a teoria da diluição tenha surgido há mais de 80 (oitenta) anos nos Estados Unidos da América pelas mãos de SCHECHTER, o qual ajudou a refletir que a teoria da diluição servia para tutelar a reputação (reputation) ou a distintividade (distinctiveness) da marca, independentemente de concorrência entre as partes ou possibilidade de erro, dúvida ou confusão quanto à proveniência dos produtos e/ou serviços.

A doutrina separa os dois tipos de diluição em: maculação e ofuscação da marca.

A maculação (tarnishment) ou denegrimento da marca consiste em uma associação causada pela similaridade entre uma marca e uma marca famosa que prejudica, danifica a reputação da marca famosa. Sobre esta associação mental salientou J. Thomas MCCARTHY que "[u]ma forma de diluição que por vezes tem sido bem sucedida nos tribunais é a utilização ilícita por um usuário júnior de uma marca famosa em um cenário que mancha as associações positivas mentais associados com a marca famosa. Maculação pode surgir quando o efeito do uso não autorizado do réu constitui em diluir por macular ou denegrir associações positivas da marca e, assim, diluir a qualidade distintiva da marca". 503

O leading case americano sobre diluição por maculação consistiu na distribuição e comercialização de um cartaz com a expressão “Enjoy Cocaine” em grafia e cores idênticas àquelas usadas nos rótulos da bebida "COCA-COLA", 504

Conhecido também é o caso Hasbro, Inc. vs. Internet Entertainment Group, Ltd., no qual a Hasbro, titular da marca "CANDY LAND” para jogos para crianças,

protected against dilution. To possess the selling power and recognition protected by the anti-dilution statues, the mark must be relatively strong and famous".

${ }^{503}$ McCARTHY. Op. cit. p. 176. No mesmo sentido, Liliane RORIZ. Op. cit. p. 185. "por maculação ofende a reputação da marca, maculando sua integridade moral, a partir do momento em que passa a ser associada com produtos de baixa qualidade ou com um conceito moral reprovável".

${ }^{504}$ Coca-Cola Co. v. Gemini Rising, Inc., 346 F. Supp. 1183 (E.D.N.Y. 1972). 
insurgiu-se contra o uso pela ré do nome de domínio www.candyland.com para identificar sítio de conteúdo pornográfico. ${ }^{505}$

Já a ofuscação ou diminuição da distintividade (blurring) significa a perda do poder de venda de uma marca famosa através do uso não autorizado por outrem em relação a produtos, a rigor, não confundíveis. O leading case americano de ofuscação refere-se a um produtor de chocolate que usava a marca "ROLLS ROYCE" para identificar seus produtos. Outro conhecido exemplo refere-se ao signo "THE GREATEST SHOW ON EARTH" usado como expressão de propaganda de Ringling Bros. que foi ilegalmente diluído por Celozzi-Ettleson ao usar o slogan "THE GREATEST USED CAR SHOW ON EARTH".506

SCHECHTER merece ser comentado, pois segundo o autor, "[O] prejuízo real em todos estes casos só poder ser aferido à luz do que foi dito a respeito da função de uma marca. É o desgaste ou dispersão gradual da identidade da marca ou nome e de sua fixação na mente do público por seu uso sobre bens que não competem entre si. Quanto mais distinta ou única for a marca, mais profunda é a sua impressão na consciência do público, e maior a sua necessidade de proteção contra contaminação ou dissociação do produto específico em relação ao qual ela está sendo usada [...] A singularidade de uma marca deve constituir a única base racional para sua proteção". 507

Jane C. GINSBURG, Jessica LITMAN e Mary L. KEVLIN são precisas ao estabelecer que o uso de uma determinada marca por mais de um titular causa diluição do seu poder distintivo e divide sua unicidade com esses terceiros. As autoras afirmam que "[d] iluição resulta quando o uso de uma marca por terceiros gera a consciência de que a marca já não significa algo único, singular ou particular, mas sim pode (ou não) denominar várias fontes diferentes. Em resumo, quando o uso de marcas iguais ou

\footnotetext{
${ }^{505}$ Hasbro, Inc. v. Internet Entertainment Group, Ltd., 1996 WL 84853, 40 U.S.P.Q.2d (BNA) 1479 (W.D. Wash, Feb. 9, 1996).

${ }^{506} \mathrm{Na}$ mesma linha, MCCARTHY. Op. cit. p. 178: "But the dilution theory rests not on the right of buyers to be free of confusion, but upon the right of the trademark owner to maximize the value of its trademark as a piece of property. In theory, dilution and likelihood of confusion cannot coexist in the mind of a single person. In seeing the junior use, e.g. ROLLS ROYCE cosmetics, one either thinks that it is affiliated with or sponsored by the owner of the famous mark or that it is not and is from a separate entity".

${ }^{507}$ SCHECHTER. Op. cit. pp. 813/833.
} 
semelhantes por outros contribua para que uma marca se torne menos distintiva do que antes, ela diluiu-se". 508

MCCARTHY ensina sobre a diluição através do denegrimento do concorrente, escrevendo que blurring é a "[u]tilização de uma marca famosa por um usuário júnior, mesmo em um produto muito distante da do usuário sênior, 'dilui' ou reduz o link exclusivo que a marca tem com o usuário sênior, seus produtos ou serviços, ou a imagem associada a ela. Considerando que a marca famosa foi anteriormente associada com apenas uma fonte, após a entrada do usuário junior, aquela marca também já está associada a uma segunda fonte, assim, 'diluindo' o poder da marca como um símbolo". 509

Para Gabriel Martinez MEDRANO, a diluição também gera prejuízo de mercado ao titular da marca. Segundo o autor, "[O] uso do prestígio dos outros não faz mal à marca, mas gera enriquecimento injusto ao infrator por apoiar suas vendas no prestígio que outro alcançou. É decidir tomar um atalho, ficando sobre os ombros de outro para penetrar no mercado". 510

Para Denis Borges BARBOSA, diluição é o processo de perda de distintividade resultante da emergência de uma pluralidade de significados, referentes, ou ambos para um só significante ${ }^{511}$, e ocorre "quando há o uso de um mesmo sinal significante por mais de um agente econômico, simultaneamente, mas fora do âmbito de proteção da marca sênior; esse uso simultâneo - quando há extravasamento do efeito simbólico da marca junior no

\footnotetext{
${ }^{508}$ GINSBURG, Jane C.; LITMAN, Jessica; KEVLIN, Mary L. Op. cit. p. 738. Tradução livre do original: "[d] ilution results when use of a mark by others generates awareness that the Mark no longer signifies anything unique, singular or particular, but instead may (or does) denominate several varying sources. In short, when use of the same or similar marks by others has caused a mark to become less distintictive than before, it has been diluted".

${ }^{509}$ MCCARTHY. Op. cit. p. 176/177. Tradução livre do original: "That is, use of a famous mark by a junior user, even on a product far removed from that of the senior user, "dilutes" or reduces the unique link that the mark has with the senior user, its goods or services, or the image associated with it. Whereas the famous mark was previously associated with only one source, after the junior user's entry, that mark is now also associated with a second source, thereby "diluting" the power of the mark as a symbol".

${ }^{510}$ MEDRANO, Gabriel Martinez. Protección contra la dilución marcaria en el Derecho Argentino. In: RABPI v. 75. Rio de Janeiro: ABPI, mar/abr 2005. Tradução livre do original: "El aprovechamiento del prestigio ajeno no daña a la marca, pero genera un enriquecimento sin causa del infractor al asentar sus ventas en el prestigio que otro ha conseguido. Es decir tomar un atajo, pararse sobre los hombros de outro para alcanzar una implantación en el mercado".

${ }^{511}$ BARBOSA, Denis. Proteção das marcas... Op. cit. p. 150.
} 
campo da marca sênior (ou potencial disso) - pode haver perda de distintividade relativa (ou valor diferencial) em desfavor da marca sênior". 512

A diluição, segundo SCHMIDT e na mesma linha de SCHECHTER, consiste na proliferação do uso da marca famosa para identificar produtos ou serviços diversos ${ }^{513}$. Segundo o autor, quanto mais fantasiosa for a marca, maior será sua originalidade e seu grau de proteção, em contraste com as marcas evocativas. ${ }^{514}$

Sob o ponto de vista semiológico, a teoria da diluição pode caracterizar a desvinculação do significado do sinal, ou seja, o uso, por terceiros, de uma marca forte em distintividade, em outros contextos que não o de sua exclusividade legal. ${ }^{515}$

De acordo com CORREA, a diluição corresponde, no direito das marcas, à inflação no campo do direito econômico. Quanto mais moeda se emite, mais desgastada se torna a unidade monetária. ${ }^{516} \mathrm{O}$ autor, com a metáfora proposta, quis dizer que a integridade da marca e sua distintividade são afetadas com a pluralidade de uso da marca por fontes distintas, erodindo sua capacidade de distinguir-se na concorrência.

Diluição de marca é definida, no dizer de Filipe Fonteles CABRAL ${ }^{517}$, como uma ofensa à integridade de um signo distintivo, seja moral ou material, por um agente que não necessariamente compete diretamente com o titular do sinal. O efeito da diluição de marca é a diminuição do poder de venda do sinal distintivo, seja pela lesão à sua unicidade, seja pela ofensa à sua reputação.

A ocupação, por terceiros, de marcas famosas por ação do seu titular impede ou dificulta a eventual ampliação futura e mesmo utilização por este do valor econômico

\footnotetext{
${ }^{512}$ BARBOSA, Denis. Proteção das marcas... Op. cit. p. 152.

${ }^{513}$ SCHMIDT. Sinais Distintivos... Op. cit. pp. 31/79.

${ }^{514}$ Esse comentário se coaduna com estudo anterior a respeito de uma análise econômica da distintividade de marcas, onde tentou-se demonstrar que a distintividade influencia diretamente na capacidade econômica de manutenção de direitos de uso exclusivo e integridade de uma marca. Cf MACHADO, Alexandre Fragoso Machado. Uma análise econômica da distintividade de marcas. Trabalho apresentado para a FDUSP em curso de pós-graduação stricto sensu durante o curso Direito e Economia ministrado pelos Profs. Drs. Rachel Sztajn, Cristiano Carvalho, Luciano Benetti Timm e Juliana Pela Krueger. São Paulo, 2010.

${ }^{515}$ BARBOSA, Denis. Proteção das marcas... Op. cit. p; 51/52.

${ }^{516}$ CORREA, Jose Antônio Faria. O Tratamento das Marcas de Alto Renome e das Marcas Notoriamente Conhecidas na Lei 9.279/96. In RABPI v. 28, maio/junho 1997. p. 36.

${ }^{517}$ CABRAL, Filipe Fonteles. Op. cit. p. 28.
} 
criado graças a seu investimento e esforço. Desta forma, não só existe lesão ao fundo de comércio, mas também perda de poder evocativo, e até mesmo pela perda material da oportunidade comercial gerada. ${ }^{518}$

Os tribunais brasileiros ${ }^{519}$ já emitiram suas opiniões a respeito da teoria da diluição, independentemente do distanciamento experimentado em relação à teoria originada nos Estados Unidos da América.

O aproveitamento parasitário (uso da marca em segmento não explorado por seu titular) afeta esta originalidade: embora não chegue a vulgarizar a marca, tem o condão de banalizá-la, ferindo seu valor comercial.

\subsubsection{A teoria da distância}

O elevado número de titulares e de marcas tornou necessária a criação pelo INPI de regras de procedimentos para definir quais delas podem coexistir pacificamente. Outro princípio concebido com essa finalidade foi instituído pela chamada teoria da distância, desenvolvida pela doutrina alemã, amplamente reconhecida no direito de marcas de inúmeros países. Segundo esta teoria, não se pode exigir, dentro de determinado ramo de atividade, que a marca nova mantenha uma distância (entendida como grau de diferenciação) maior em relação a outras marcas pertencentes a titulares diferentes, do que estas mantêm entre si.

Não se pode perder de vista que a teoria da distância ocorre entre marcas distintivas, ou seja munidas de certa integridade material, mesmo que o grau de distintividade não seja de uma marca fantasiosa ou arbitrária. Habitualmente, encontram-se cenários de coexistência de marcas muito parecidas quando as mesmas são compostas por

\footnotetext{
${ }^{518}$ BARBOSA, Denis. Proteção das marcas... Op. cit. p. 138. O autor ainda comenta que, independentemente da qualidade do produto do copista parasitário, sem quebra da boa fama da marca famosa copiada, restaria o enfraquecimento do signo, pelo watering (diluição) de sua distintividade relativa (em face de competidores).

${ }^{519}$ TRF 2 ${ }^{\mathbf{a}}$ Região. Ap. Cível n ${ }^{\circ}$ 2002.51.01.514660-7. Segunda Turma Especializada. Rel. Des. Liliane Roriz. Julgado em 22 de agosto de 2006. DJU de 04 de setembro de 2006. “(...) A idéia principal da teoria da diluição é a de proteger o titular contra o enfraquecimento progressivo do poder distintivo de sua marca, mormente em casos de marcas que ostentam alto grau de reconhecimento ou que sejam muito criativas, sendo o paradigma para a decisão entre aplicar a teoria da distância ou a teoria da diluição a fama e a criatividade do sinal".
} 
elementos demasiadamente evocativos ou sugestivos, beirando a irregistrabilidade objeto do já citado inciso VI do artigo 124 da LPI.

GEERT E. SEELIG ${ }^{520}$, um dos autores que melhor estudou a teoria, resume o seu fundamento ao ensinar que "[F]reqüentemente, marcas idênticas ou similares são utilizadas em campos de atividades idênticas ou afins. Em geral, o público consumidor está habituado à coexistência destas marcas e presta maior atenção às diferenças existentes entre elas. Se, por sua vez, novas marcas parecidas vem se juntar às antigas, o público não as confundirá com aquelas já existentes porque já está habituado a prestar atenção às suas diferenças, mesmo que fracas, e sabe por conseqüência distinguí-las. A conseqüência desse processo é que o risco de confusão entre as marcas diminui. Se as marcas, então apresentavam um perigo real de confusão, esta possibilidade está agora excluída e o risco inicial descartado".

Tal teoria já foi objeto de crítica pelo nosso Poder Judiciário, ao julgar o caso SILASTIC vs. JILASTIC, cujas marcas foram interpretadas como suficientemente distintas entre si, sendo que a análise ortográfica do sufixo LASTIC foi determinante pois tal elemento evoca produtos de borracha e elasticidade, convertendo-se de descritividade e por isso, improvável de ser protegido exclusivamente por uma ou outra parte, as quais " $[h] \tilde{a} o$ que suportar o ônus da convivência com outras marcas". 521

Outro caso judicial interessante é o da marca ESTHETIC CENTER, no qual o STJ julgou que a expressão, sendo de uso comum e parte das marcas das empresas em confronto, passível de ser utilizada pacificamente como sinônimo de centro comercial. ${ }^{522}$

Pouco se tem ouvido da doutrina e dos nossos tribunais sobre a aplicação da teoria da distância. Tal teoria presume a prática continuada de deferimentos de marcas plenamente distintivas similares umas às outras designando produtos ou serviços de uma mesma atividade empresarial. Ou seja, critica-se aqui o motivo original de deferimento de

\footnotetext{
${ }^{520}$ SEELIG, Geert E. La Théorie de la Distance. In: Revue Internationale de la Propriété Industrielle et Artistique, nº 62, Dez. 1965, pág. 389 - Tradução Livre.

${ }^{521}$ TRF $2^{\mathbf{a}}$ Região. Ap. Cív. 90.02.22886-4, $3^{\text {a }}$ Turma. Rel. Des. Fed. Celso Passos, JSTS e TRF 52/332. No mesmo sentido, JSTS e TRF 54/480;

${ }^{522}$ STJ, REsp nº 6.416-PR, $3^{\text {a }}$ Turma. Rel. Min. Cláudio Santos, DJU 18/02/1991.
} 
um segundo pedido de marca semelhante com o anterior, causando eventual desgaste da distinção do primeiro registro.

Liliane RORIZ já se expressou sobre o tema quando defendeu proteção especial às marcas fortes ao escrever que "[N]o segundo caso, porém, como se trata de uma marca forte, a relativização de sua proteção pode debilitá-la, não por fatores intrínsecos, mas sim por fatores externos, indepente da vontade de seu titular, enfraquecendo-a, ante o crescente aumento de registros semelhantes em seu processo gradual e constante que termina por banalizar um signo originalmente distintivo em si mesmo". 523

Em tese, tal prática não deveria ocorrer já que, em havendo similitude entre o registro mais antigo e o pedido mais novo, e sendo que ambos designam produtos idênticos ou semelhantes, a decisão obrigatória do INPI seria a de indeferimento do pedido mais novo e não, o deferimento determinando uma menor distância distintiva entre um signo e outro.

Denis BARBOSA cita o exemplo de convivência entre as marcas FABLUM, CARBLUM e TIBLUM. E explica que uma marca que já convive pacificamente com outras a ela semelhantes, identificando produtos idênticos ou afins, terá, pois, fraca eficácia distintiva. ${ }^{524}$ Tal e qual o caso das marcas formadas a partir de prefixos ou sufixos tão comuns referentemente a certo tipo de produto. Na visão do autor, a presença, em um mesmo ramo de comércio, ou em atividade afim, de várias marcas semelhantes, é capaz de desenvolver uma sensibilidade mais apurada no consumidor, que virá a reconhecer a força identificadora das marcas nos detalhes característicos que de suas diferenças respectivas.

Os motivos de causa dessa prática podem ser muitos, como a falta de organização da jurisprudência administrativa da Diretoria de Marcas do INPI, ou indícios de desgaste de determinado elemento pelo uso corriqueiro no mercado, ou até mesmo a

\footnotetext{
${ }^{523}$ RORIZ, Liliane. Op. cit. p. 184.

${ }^{524}$ BARBOSA, Denis. Proteção das marcas... Op. cit. p. 92.
} 
falta de indicação da existência de um acordo de coexistência firmado entre dois titulares diferentes. $^{525}$

Exemplos práticos de aplicação da teoria da distância existem em grande número. SCHECHTER já analisava a distinção entre as marcas assinalando que "[A] regra que marcas ou nomes arbitrários, cunhados ou fantasiosos devem possuir um grau muito maior de proteção do que símbolos, palavras ou frases de uso comum parece ser inteiramente sentido. Essas marcas ou nomes comerciais como "Blue Ribbon", usado, com ou sem registro, para todos os tipos de mercadorias ou serviços, mais de 60 vezes; "Simplex" mais de 60 vezes, "Anchor", já registrada mais de 150 vezes em 1898; "Bull Dog", mais de cem vezes em 1923, "Gold Medal", 65 vezes; "3-in-1" e "2-in-1", 79 vezes; "Nox-All", 50 vezes; "Universal", mais de 30 vezes, "Lily White" mais de 20 vezes; - todas essas marcas e nomes têm, a esta altura, muito pouco caráter distintivo na mente do público, e na maioria dos casos sugerem destaque, mérito ou outras qualidades de produtos ou serviços em geral, e não o fato de o produto ou serviço, em relação ao qual a marca ou nome é usado, emana de uma fonte especifica". ${ }^{526}$

Seguindo o exercício conduzido acima, em pesquisa realizada na base de dados do INPI, verificou-se que marcas, em princípío, distintivas em relação aos seus produtos têm sua distinção desgastada pelas decisões do INPI. Abaixo, dois exemplos:

\footnotetext{
${ }^{525}$ Atualmente, o INPI tem desferido sérias críticas à aceitação de acordos de coexistência entre titulares sem qualquer relação societária ou negocial, suscitando a insegurança que a prática oferece à base de dados do INPI, mas também seu entendimento da imprecisão que as coexistências podem ocasionar no mercado, e mais importante ainda, entre os consumidores. Apesar de tais críticas ainda não terem sido transformadas em uma diretriz expressa do órgão, não podemos descartar que estamos caminhando a passos largos nesse sentido.

${ }^{526}$ SCHECHTER. Op. cit. pp. 828/829. Tradução livre do original: "The rule that arbitrary, coined or fanciful marks or names should be given a much broader degree of protection than symbols, words or phrases in common use would appear to be entirely sond. Such trademarks or tradenames as "Blue Ribbon", used, with or without registration, for all kinds of commodities or services, more than sixty times; "Simplex" more than sixty times; "Anchor", already registered over one hundred fifty times in 1898; "Bull Dog", over one hundred times by 1923; "Gold Medal", sixty-five times; "3-in-1" and "2-in-1", seventy-nine times; "Noxall", fifty times; "Universal", over thirty times; "Lily White" over twenty times; - all these marks and names have, at this late date, very little distinctiveness in the public mind, and in most cases suggest merit, prominence or other qualities of goods or services in general, rather than the fact tha the product or service, in connection with which the mark or name is used, emanates from a particular source".
} 
(a) Elemento BEIJ para vestuário: Em tese, qualquer variação a partir desse radical é plenamente distintiva em relação a esses produtos. Entretanto, há 14 (quatorze) registros de marca com o radical em nome de 11 (onze) titulares diferentes. ${ }^{527}$

(b) Elemento STAR para vestuário: Da mesma forma, encontram-se mais de 90 (noventa) registros de marca em nome de 80 (oitenta) titulares diferentes. ${ }^{528}$

Todavia, é necessário condicionar qualquer discussão nessa seara aos entendimentos manifestados historicamente pelo INPI, já que, via de regra, os tribunais brasileiros confiam na opinião da autarquia, em virtude do envolvimento técnico diário ds examinadores de marcas do INPI na análise dos milhares de pedidos de registro de marca apresentados à mesma todos os anos.

\subsection{Os limites (Fair use)}

O rol dos usos permissivos de marcas de terceiros compreende as limitações ao direito de uso exclusivo atribuído ao titular, com vistas aos interesses da concorrência, do consumidor ou da liberdade de palavra. ${ }^{529}$ A marca, além de ser um instrumento de comunicação com o público, também é um instrumento de concorrência e compromisso com o consumidor. E como expressão linguística, a marca faz parte dos direitos fundamentais de uso da língua, de forma livre e construtora dos valores humanos. Assim, nasce a tensão entre o direito constitucional à informação e exclusividade legal do titular da marca. ${ }^{530}$

Não há que se falar, por exemplo, em impedir o uso semântico das palavras enquanto as mesmas não forem utilizadas como marca. Frases como "O globo não para de girar" ou "Veja como aquela atriz é bonita" não podem ser proibidas por mais que

\footnotetext{
${ }^{527}$ Registros de marca compostos por $B E I J$ que designam produtos do vestuário, encontrados na base de dados do INPI: 816052492, 820791849, 821264559, 821940422, 822343819, 823137350, 823658341, 823816699, 825647479, 826152520, 826106382, 826684114, 826684122, 828485860 e 900802090.

${ }^{528}$ Registros de marca compostos por STAR que designam produtos do vestuário, encontrados na base de dados do INPI, concedidos apenas entre 2009 e 2010: 820626830, 820616311, 823410021, 824133773, $824603672,824691032,825290171,825638585,825745128,826987567,827713118,828440468$, $828639159,828655065,900012420,900325739,829125086,829125094,829243593,829344209$, 900803584 e 900882360.

${ }^{529}$ BARBOSA, Denis. Proteção das marcas... Op. cit. p. 347.

${ }^{530}$ BARBOSA, Denis. O Direito Constitucional dos Sinais Distintivos... pp. 17/18.
} 
GLOBO e VEJA sejam marcas registradas. De acordo com MCCARTHY, "[U]m usuário júnior possui sempre o direito de usar um termo de boa-fé em seu sentido primário, descritivo. Tal defesa é mais freqüentemente feita contra uma designação que está determinada a ser descritiva dos bens do Autor. Tal marca descritiva exige prova de significado secundário de registro e proteção. Assumindo tal prova, a palavra ou símbolo tem dois significados: (1) de seu antigo, significado 'primário' na língua, que existiu antes do uso do queixoso, (2) de seu novo, o significado 'secundário' da marca como um símbolo de identificação de bens do reclamante e serviços. A visão da maioria é de que um pode fazer um 'uso justo' descritivo e não-infrator, mesmo se o usuário sênior não estiver usando o termo em um sentido descritivo com seus produtos ou serviços". 531

Ou seja, a marca registrada não garante direito absoluto ao seu titular.

\subsubsection{Liberdade de expressão}

A Declaração Universal dos Direitos Humanos, assim estabeleceu em seu artigo 19, "[T]odos têm o direito à liberdade de opinião e de expressão; este direito inclui a liberdade de sustentar opiniões sem interferência e procurar, receber e transmitir informações e ideias mediante quaisquer meios e independentemente de fronteiras ". 532

Por mais que o uso de uma marca atente contra a integridade material da mesma ou à integridade moral do seu titular, se ele for considerado justo, o uso será permitido. É impensável negar o direito à informação e o direito à liberdade de expressão garantidos pela $\mathrm{CF} / 88$, em seus artigos $5^{\circ}$, inciso $\mathrm{IX}^{533}$ e $220 .{ }^{534}$ Independentemente do

\footnotetext{
${ }^{531}$ MCCARTHY. Op. cit. p. 232: O autor se apóia no julgado do tribunal americano Car-Fresher Corp. $v$. S.C. Johnson \& Son, Inc., 70 F.3d 267, 36 USPQ2d 1855, (2d Circ, 1995). Tradução livre do original: "[A] junior user is always entitled to use a term in good faith in its primary, descriptive sense. Such a defense is most often made as against a designation that is determined to be descriptive of the plaintiff's goods or services. Such a descriptive mark requires proof of secondary meaning for registration and protection. Assuming such proof, the word or symbol has two meanings: (1) its old, "primary" meaning in the language, which existed prior to the plaintiff's usage; (2) its new, "secondary" trademark meaning as an identifying symbol for the plaintiff's goods and services. The majority view is that one can make a non-infringing, descriptive "fair use" even if the senior user is not using the term in a descriptive sense with its goods or services".

${ }^{532}$ Disponível em http://portal.mj.gov.br/sedh/ct/legis_intern/ddh_bib_inter_universal.htm. Acessado em $05 / 12 / 2012$.

${ }^{533}$ Art. 50, IX CF/88: "é livre a expressão da atividade intelectual, artística, científica e de comunicação, independentemente de censura ou licença”.
} 
direito garantido aos titulares, o interesse do bem comum impõe limites ao direito de cessar o uso desautorizado de suas marcas.

Ainda, o artigo 215 da CF/88 garante ao cidadão o acesso livre aos direitos culturais e fontes da cultura nacional, sendo que as formas de expressão fazem parte do patrimônio cultural brasileiro de acordo com o artigo 216 da Carta Magna.

Já ficou decidido pelo STF sobre o direito constitucional de liberdade de expressão, independentemente dos resultados trazidos por essa exposição de opiniões:

"Nessa medida, gozam da plenitude de liberdade que é assegurada pela Constituição à imprensa. Dando-se que o exercício concreto dessa liberdade em plenitude assegura ao jornalista o direito de expender críticas a qualquer pessoa, ainda que em tom áspero, contundente, sarcástico, irônico ou irreverente, especialmente contra as autoridades e aparelhos de Estado. Respondendo, penal e civilmente, pelos abusos que cometer, e sujeitando-se ao direito de resposta a que se refere a Constituição em seu art. $5^{\circ}$, inciso $V$. A crítica jornalística em geral, pela sua relação de inerência com o interesse público, não é aprioristicamente suscetível de censura". 535

Na mesma linha, "[A] liberdade de expressão constitui um dos fundamentos essenciais de uma sociedade democrática e compreende não somente as informações consideradas como inofensivas, indiferentes ou favoráveis, mas também as que possam causar transtornos, resistência, inquietar pessoas, pois a Democracia somente existe baseada na consagração do pluralismo de idéias e pensamentos, da tolerância de opiniões e do espírito aberto ao diálogo". 536

Por outro lado, "[A] manifestação do pensamento não raro atinge situações jurídicas de outras pessoas que se socorrem do direito individual, também fundamental, de resposta". 537 Ou seja, em que pese a liberdade de expressão oferecida a todos, a

\footnotetext{
${ }^{534}$ Art. 220 CF/88. "A manifestação do pensamento, a criação, a expressão e a informação, sob qualquer forma, processo ou veículo não sofrerão qualquer restrição, observado o disposto nesta Constituição. $\S 1^{o}$ Nenhuma lei conterá dispositivo que possa constituir embaraço à plena liberdade de informação jornalística em qualquer veículo de comunicação social, observado o disposto no art. $5^{\circ}, I V, V, X$, XIII e XIV".

${ }_{535}^{5 T}$ STF, ADI 4451, Plenário. Rel. Min. Ayres Brito, DJ 26.08.2010.

${ }^{536}$ MORAES, Alexandre. Constituição do Brasil Interpretada e Legislação Constitucional. São Paulo: Atlas, 2002, p. 206.

${ }^{537}$ SILVA, José Afonso da. Curso de Direito Constitucional Positivo. São Paulo: Ed. Malheiros, 2003. p. 252.
} 
informação prestada pode alcançar, de forma positiva ou negativa, a reputação de alguém ou a integridade material de uma marca, dependendo da manifestação.

Note-se do texto legislativo ${ }^{538}$ que o uso da marca de terceiro será lícito se não houver conotação comercial e não prejudique seu caráter distintivo. No que tange a esse último requisito, queria o legislador evitar o uso, inicialmente lícito, mas que pudesse a contribuir para a perda de integridade material da marca. Um exemplo possível é o de um veículo de comunicação, ao comunicar um fato, utilizar marca de um titular como sinônimo do gênero do produto, contribuindo para a sua vulgarização. Um título de matéria que ilustra essa hipótese seria: "Permitido o xerox de capitulos em copiadoras de faculdades". Veja que a marca XEROX foi utilizada como sinônimo de fotocópia, utilização essa que certamente a titular da marca deveria combater.

Fazendo parte do direito de liberdade de expressão, encontra-se o direito de uso livre da língua ou de imagens pertencentes ao domínio comum. Assim, não se pode singularizar ou apropriar-se de um signo que já tem curso livre na língua (ou no uso semiótico das imagens), pois, entre outras objeções, haveria uma restrição injustificável da liberdade de expressão. ${ }^{539}$ A Propriedade Intelectual não pode coibir, irrazoável e desproporcionalmente, o acesso à informação por parte de toda a sociedade, e o direito de expressão de cada um.

Isto posto, a forma de expressão, quando cristalizada em forma de marca registrada, garante o direito de uso exclusivo ao titular de uma espécie de expressão linguística. Por isso é que o direito de uso exclusivo não alcança outros contextos de utilização da forma de expressão. Até porque, "[A] propriedade intelectual é uma ilha de exclusividade num oceano de liberdades". ${ }^{540}$ Assim, caso a palavra esteja sendo utilizada em seu sentido descritivo, ou seja, o termo chave para descrever a ferramenta de abertura de uma porta ou cadeado, então não há infração. Do outro lado, se houver uso da marca

\footnotetext{
${ }^{538}$ Art. 132, inciso IV LPI: Vide nota 269.

${ }^{539}$ BARBOSA, Denis. Proteção das marcas... Op. cit. p. 229.

${ }^{540}$ GEIGER, Christophe - Trade Marks and Freedom of Expression - The Proportionality of Criticism. In International Review of Intellectual Property and Competion Law, v. 38, n.3, 2007, pp. 317/327.
} 
CHAVES que designa um suco de frutas, sendo que o uso faz remissão ao produto designado, então poderá haver infração. ${ }^{541}$

$\mathrm{Na}$ origem, todo elemento ou palavra possui seu sentido descritivo. Todavia, após ser escolhido para individualizar um titular, ele deixa de ter somente o sentido descritivo e passa a ter o sentido de sinal distintivo. Nessa linha de raciocínio, o TJPR decidiu que o uso de uma expressão em sentido genérico não infringe marca de terceiro. Foi o caso da marca PAIXÃO para perfumes. ${ }^{542}$

No mesmo sentido, BEEBE comenta que se a função distintiva não estiver sendo desempenhada nem representada não haverá marca. ${ }^{543}$ Logo, se faz necessário que o contexto do uso indique que a palavra foi usada em função marcária. Se não houver uso como marca, o signo deixará de ser analisado e compreendido como tal.

Dessa forma, há de se encontrar um equilíbrio entre o direito sobre a marca e o direito fundamental de expressão.

De acordo com Ana Carolina Cagnoni RIBEIRO, há quem diga que o conflito entre a liberdade de expressão e o direito de marcas repousa na frequente e crescente ocupação da res communis omnium, exercendo verdadeira barreira ao uso do vocábulo livremente. E essa limitação, no entender da autora, "pode tornar-se perpétua, dado que a proteção conferida às marcas é, em última instância, ilimitada diante da possibilidade infinita de sua prorrogação pelo titular", 544

Há de se comentar também que o valor da marca para a comunicação aumentou muito nas últimas décadas. Como a própria Ana Carolina RIBEIRO aponta que "[C]omo parte da nossa rotina, marcas são deliberadamente inseridas em nossas mentes e, quase que inconscientemente, inseridas em nosso vocabulário". ${ }^{545} \mathrm{O}$ que existe, na

${ }^{541}$ STF, $1^{a}$ Turma, Recurso Extraordinário 49778, Rel. Min. Gonçalves de Oliveira, j. 28.06.1962, publ. RTJ v. 23, pp. 414/418. O Supremo Tribunal decidiu que o uso da expressão Palace Hotel não tem conotação marcária, mas sim de uma qualidade superior de hotel.

${ }^{542}$ TJPR, $10^{\text {a }}$ Câmara Cível, AC 265.340-1, Rel. Des. Fagundes Cunha, j. 20.10.2006.

${ }^{543}$ BEEBE. Op. cit. pp. 645/646.

${ }^{544}$ RIBEIRO, Ana Carolina Cagnoni. Marcas registradas e liberdade de expressão: o posicionamento americano e o recente dilema europeu. In RABPI v. 110, jan/fev 2011. Rio de Janeiro: ABPI, 2002. p. 62. ${ }^{545}$ RIBEIRO, Ana Carolina Cagnoni. Op. cit. p. 62. 
verdade, é uma apropriação da linguagem, antes comum a todos, através da obtenção de registros de marca.

A autora ainda cita um importante julgado norte-americano que relativizou a noção das marcas famosas, populares na linguagem, ao permitir o uso da personagem BARBIE em uma música de sucesso que satirizava o life style americano. Citando uma parte da decisão americana, ficou decretado que "[a] propriedade sob uma marca não dá a seu detentor o direito de impedir uso não autorizado por terceiro que está comunicando suas ideias ou expressando seus pontos de vista". 546

Há que se ressalvar, todavia, que a liberdade de expressão e o direito de informação não podem ser violados pelos atos de concorrência desleal, os quais são passíveis de punição pela LPI e encontram resguardo na CUP, que tem a melhor definição para os atos de concorrência desleal em seu art 10 bis (2): “[C]onstitui ato de concorrência desleal qualquer ato de concorrência contrário aos usos honestos em matéria industrial ou comercial'.

O texto simples da CUP traz a difícil missão de se identificar o significado de honestidade no comércio, pois apesar de designar um modelo, a definição de concorrência desleal da CUP não encerra os limites de análise desse importante instituto da Propriedade Intelectual.

No mesmo sentido, manifestou o STF, ao dispor da irrestrita liberdade de concorrência protegida constitucionalmente, ao decidir que "[A] livre concorrência, como toda a liberdade, não é irrestrita. O seu direito encontra limites nos preceitos legais que a regulam e nos direitos dos outros concorrentes, pressupondo um exercício legal e honesto do direito próprio, expressivo da probidade profissional, excedidos esses limites surge a concorrência desleal... procura-se no âmbito da concorrência desleal combater os atos de concorrência fraudulenta ou desonesta, que atentam contra o que se tem como correto ou normal no mundo dos negócios, ainda que não infrinjam diretamente patentes ou sinais registrados". 547

\footnotetext{
${ }^{546}$ RIBEIRO, Ana Carolina Cagnoni. Op. cit. p. 64. A autora comenta o caso Mattel, Inc v. MCA Records, Inc., 296 F. 3d. 894, Court of Appeals, 9th Circuit 2002.

${ }^{547}$ STF. Rext no $5532.2^{\text {a }}$ Turma. DJU 11/10/1949, In RT 184/914
} 
Na doutrina, BITTAR e BITTAR FILHO ${ }^{548}$ ensinam que a utilização de sinais distintivos precisa respeitar os princípios e as regras que regem a atividade empresarial, os quais são inspirados nos ditames morais que procuram conduzir o exercício comercial por um caminho reto, evitando conflitos ou invasões da esfera alheia, respeitando-se a livre concorrência, instituto assegurado pela $\mathrm{CF} / 88 .^{549}$

DI FRANCO afirma que “[o] conceito jurídico de concorrência desleal é por pressuposto o fato econômico da competição e mais precisamente da livre concorrência, que constitui-se o desvio humano perturbador do senso moral que deve preceder as relações de comércio e indústria, e o não cumprimento torna-se a fonte de ilícito". 550

\subsubsection{Direito à crítica}

Já o direito à crítica é consagrado na Lei de Imprensa (Lei ${ }^{\circ} 5.250$, de 09 de fevereiro de 1967), cujo artigo 27, inciso I preconiza que "Não constituem abusos no exercício da liberdade de manifestação do pensamento e de informação: I - a opinião desfavorável da crítica, literária, artística, científica ou desportiva, salvo quando inequívoca a intenção de injuriar ou difamar;(...)”. É preciso reconhecer que o ser humano possui natureza de discordância. É o direito ao conflito de ideias, de posições, sejam elas de qualquer natureza.

O direito de crítica caracteriza-se como o direito subjetivo público de formação e expressão de juízos críticos sobre pessoas, idéias, ações ou omissões cujas circunstâncias em que se apresentem permitam inferir sobre o caráter público ou evidência social das mesmas.

\footnotetext{
${ }^{548}$ BITTAR e BITTAR FILHO. Op. cit. p. 100.

${ }^{549}$ Artigo 170 da CF/88.

${ }^{550}$ DI FRANCO, Luigi. Proprietà Industriale, Letteraria ed Artistica. Milão: SEL, 1928. p. 435. Traduzido de: "[i]l concetto giuridico di concorrenza sleale è per pressuposto il fatto econômico della concorrenza e più precisamente della libera concorrenza, della quale constituise uma devianzione turbatrice del senso morale Che deve precedere ai rapporti dell'industria e del commercio, e la cui inosservanza assurge a fonte di illecito".
} 
De acordo com Claudio de GODOY ${ }^{551}$, que utiliza lição de René Ariel DOTTI, a crítica "[é] entendida como os juízos valorativos propostos pelo homem, 'a partir da análise sobre o conteúdo e veracidade dos acontecimentos que lhe são transmitidos". 552

Conclui GODOY que "[o] direito de crítica, concebido como expressão da liberdade de opinião, constitucionalmente garantido, de per si, mesmo exercido de modo veemente, com conteúdo de boa ou má qualidade, e quando não animado por sentimento pessoal, subjetivo, de antagonismo a pessoa certa, não é causa de abuso da liberdade de imprensa". 553

\subsubsection{Publicidade comparativa}

Outro limite imposto ao direito de uso exclusivo de marcas registradas é a propaganda comparativa. Por mais que o uso de marcas de terceiros com conotação comercial seja proibida pela $\mathrm{LPI}^{554}$, a publicidade comparativa é permitida em nosso ordenamento. Interesses em conflito: direito de informação ao consumidor e direito de impedir uso desautorizado com conotação comercial.

A publicidade é definida por BITTAR como "[m]ola propulsora do extraordinário avanço empresarial de nosso tempo" que provoca "reações de consumo em cadeia, como instrumento imprenscindível à expansão negocial"555. Continua o autor, em outra de suas obras, denotando que "[n] ascida por exigências da Revolução Industrial, que possibilitou a produção em massa, requerendo portanto novos mercados para o seu

${ }^{551}$ GODOY, Claudio Luiz Bueno de. A liberdade de imprensa e os direitos da personalidade. São Paulo: Atlas, 2001. p. 100.

${ }_{552}$ DOTTI, René Ariel. Proteção da vida privada e liberdade de informação. São Paulo: RT, 1980. p. 216.

${ }^{553}$ GODOY. Op. cit. p. 128. No mesmo sentido, Darcy Arruda Miranda comenta que a crítica precisa estar imotivada de mera animosidade pessoal. In Comentários à Lei de Imprensa. $3^{a}$ ed. São Paulo: RT, 1995. p. 478/479.

${ }^{554}$ A publicidade comparativa não trata da exceção do artigo 132 IV da LPI, pois este permite o uso de marcas de terceiros sem fins comerciais. No mesmo sentido, Lélio SCHMIDT entende que a diluição ou denegrimento da marca são inerentes à publicidade comparativa. Sua prática estaria fora do permitido pelo artigo 132, IV da LPI, que trata da possibilidade de uso de marca de terceiro sem conotação comercial, já que qualquer publicidade tem cunho empresarial. Anota o autor: "A publicidade, portanto, há de ficar restrita ao enfoque das eventuais qualidades e características do produto do anunciante, não podendo abarcar aspectos diversos, ainda que verídicos, relacionados à marca do concorrente". In: SCHMIDT, Lélio. A publicidade comparativa à luz da lei de propriedade industrial. In: RABPI v. 52. Rio de Janeiro: ABPI, mai/jun 2001. pp. $6 / 7$.

${ }^{555}$ BITTAR, Carlos Alberto e BITTAR FILHO, Carlos Alberto. Op. cit. p. 45. 
escoamento, de tal forma a publicidade se conjugou à atividade empresarial que esta hoje depende substancialmente de sua atuação". 556

A atividade publicitária é livre enquanto meio de realização do princípio da livre concorrência e, na mesma linha, pode ser entendida como livre enquanto meio de expressão. Contudo, ela não se dá de modo irrestrito. ${ }^{557}$

De acordo com o regramento do CONAR, a publicidade comparativa é permitida, obedecendo-se os limites do artigo 32 do seu Código Brasileiro de AutoRegulamentação Publicitária:

Artigo 32. Tendo em vista as modernas tendências mundiais - e atendidas as normas pertinentes do Código da Propriedade Industrial (Lei $n^{o}$ 5.772, de 21 de dezembro de 1971) - a publicidade comparativa será aceita, contanto que respeite os seguintes princípios e limites:

a. seu objetivo maior seja o esclarecimento, se não mesmo a defesa do consumidor;

b. tenha por princípio básico a objetividade na comparação, posto que dados subjetivos, de fundo psicológico ou emocional não constituem uma base válida de comparação perante o Consumidor;

c. a comparação alegada ou realizada seja passível de comprovação;

d. em se tratando de bens de consumo a comparação seja feita com modelos fabricados no mesmo ano, sendo condenável o confronto entre produtos de épocas diferentes, a menos que se trate de referência para demonstrar evolução, o que, nesse caso, deve ser caracterizado;

e. não se estabeleça confusão entre produtos e marcas concorrentes;

f. não se caracterize concorrência desleal, denegrimento à imagem do produto ou à marca de outra empresa;

g. não se utilize injustificadamente a imagem corporativa ou o prestígio de terceiros;

h. quando se fizer uma comparação entre produtos cujo preço não é de igual nível, tal circunstância deve ser claramente indicada pelo anúncio.

Mesmo considerando a aparente limitação da liberdade ao discurso fora do comércio (art. 132, IV da LPI), tem-se afirmado na prática constitucional a liberdade de uso das marcas mesmo no discurso comercial, no contexto da publicidade comparativa. ${ }^{558}$

\footnotetext{
${ }^{556}$ BITTAR, Carlos Alberto. Direito de Autor na Obra Publicitária. $1^{\text {a }}$ ed. São Paulo: RT, 1981. p. 17.

${ }^{557}$ MAZZONETTO, Nathalia. A publicidade comparativa e a prática de concorrência desleal por meio do denegrimento de marca e da imagem do concorrente. In RABPI v. 99. Rio de Janeiro: ABPI, , mar/abr 2009. p. 4.

${ }^{558}$ BARBOSA, Denis. Proteção das marcas... Op. cit. p. 116.
} 
Para melhor ilustrar a permissividade do ato publicitário comparativo, transcreve-se um texto de parecer do CONAR: "A propaganda comparativa é uma técnica moderna e avançada, hoje utilizada em larga escala nos Estados Unidos e outros países e ainda engatinhando no Brasil. Não vamos aqui tecer nenhuma tese sobre propaganda comparativa, mas apenas destacar alguns conceitos universalmente aceitos $e$ consagrados. [Os] produtos comparados devem ser informativos e exatos, evitando-se sofismas, ou dúbia interpretação. A propaganda comparativa é, na realidade, um instrumento do consumidor, pois através dela ele terá opções de decisão". 559

Assim, a liberdade de escolha do consumidor depende da informação clara, completa e verdadeira sobre o produto ou serviço acerca das suas qualidades e vantagens. 560

$\mathrm{Na}$ doutrina, a publicidade comparativa é definida como um "método, ou técnica, de confronto empregado por um anunciante, destinado a enaltecer as qualidades ou preço de seus produtos ou serviços em relação a produtos ou serviços de um ou mais concorrentes, explícita ou implicitamente". 561

O ponto central da questão da publicidade comparativa para o presente estudo está na utilização desautorizada da marca de concorrente com o objetivo de enaltecer seu produto ou serviço. A comparação só será buscada na publicidade se for em benefício do anunciante. Do contrário, a discussão seria inócua. Desse jeito, o anunciante utiliza marca do concorrente, e independentemente da veracidade e equilíbrio de sua peça publicitária, gerará consequência à integridade material da marca do concorrente que teve sua marca envolvida.

Para Hermano DUVAL, a publicidade comparativa sempre criará depreciação dos produtos e serviços do concorrente, pois o anunciante enaltece seus próprios produtos em detrimento do outro. Assim, para o autor, o objetivo do anunciante é depreciar o poder

\footnotetext{
${ }^{559}$ CONAR, Representação no 013/79. Denunciante: Volkswagen do Brasil S.A. Anunciante: Fiat Automóveis S.A. Rel. Conselheiro Luiz Marcelo Dias Sales. Apud BARBOSA Denis. Proteção das marcas... Op. cit. pp. 352/353.

${ }^{560}$ DANNEMANN. Op. cit. p. 267.

${ }^{561}$ PEREIRA, Marco Antônio Marcondes. Concorrência desleal por meio da publicidade. São Paulo. Juarez de Oliveira, 2001. p. 89.
} 
de venda do concorrente. ${ }^{562}$ Note-se que esse resultado será alcançado se a publicidade comparativa for lícita ou ilícita.

Celso DELMANTO também entende dessa forma e adiciona que "[A] afirmação verdadeira pode ser publicada, divulgada ou prestada, mesmo em forma comparativa (comparandi causa), desde que o agente dela não se valha como arma fraudulenta para competir desonestamente,. 563

Pesam a favor da publicidade comparativa os fatores de (a) promoção à livre iniciativa, garantia constitucional; (b) oferta de informações que podem ser vantajosas ao consumidor; (c) possibilidade de evolução dos produtos e serviços.

Os tribunais brasileiros, apesar da larga aplicação do conceito nas representações do CONAR, já decidiram pela manutenção da propaganda comparativa:

Ementa: CONCORRÊNCIA DESLEAL. Arts. Io, IV e 170, IV, ambos da CF/88. Adoção do modelo econômico neoliberal pela República Federativa do Brasil. Consagração do principio da livre iniciativa, mas que a própria ordem constitucional faz temperamentos, pois, de forma explicita e implícita, a CF/88 consagrou valores, normas e princípios que devem ser respeitados $e$ harmonizados na ordem econômica, prova disso são os incisos do citado art. 170 que estabelecem princípios informadores, sendo que tal situação, retratada pelo texto constitucional, é própria das constituições classificadas como ecléticas, as quais possuem o que se denomina de caráter compromissório, ou seja, o compromisso de harmonizar as várias ideologias contidas no seu texto, portanto, especificamente, a CF/88 ao consagrar a livre iniciativa também estabelece determinadas situações que limitam o seu exercício para que não se afronte, de forma desenfreada, outros valores também consagrados pelo Poder Constituinte Originário. Caso concreto em que informes publicitários comparativos, contendo informações sobre percentual de aprovados em universidades e outras características do serviço educacional oferecido que não caracteriza deslealdade concorrencial, mormente quando não há provas acerca da falsidade das informações divulgadas. LITIGANCIA DE MÁ-FÉ. Não caracterização. Má-fé do litigante que não se presume. Não demonstração de dolo processual. Honorários advocaticios. Majoração. Valor que deve ser arbitrado, por equidade, nos

\footnotetext{
562 DUVAL, Hermano. Concorrência desleal. São Paulo: Saraiva, 1976. p. 138.

${ }^{563}$ DELMANTO, Celso. Crimes de concorrência desleal. São Paulo: Universidade de São Paulo, 1975. pp. 97/98.
} 
termos do artigo 20,, 40, CPC. Recurso da autora não provido. Recurso da ré parcialmente provido ${ }^{564}$.

Comentários: O julgado acima valeu-se da facilitação da informação para o consumidor e descaracterizou a intenção depreciativa da parte vencedora. Em sendo a informação verdadeira, a comparação publicitária é lícita.

Ementa: MARCAS Ação de obrigação de não fazer - Uso indevido de marca e concorrência desleal - Panfletos que se destinavam aos funcionários da ré e dos distribuidores dos produtos dela e, portanto, não têm natureza comercial Ausência de prova de que os dados contidos no informe não são verdadeiros, mas, de todo modo, não denigrem propriamente os produtos da autora Informativo contendo orientações a respeito do posicionamento dos produtos nas prateleiras e gôndolas que, por si só, não implica benefício de um em detrimento de outro Recurso da autora não provido. APELAÇÃO ADESIVA Interesse recursal Ação principal e reconvenção julgadas improcedentes Mútua sucumbência - Lei que não exige que a matéria objeto do adesivo esteja relacionada com a do recurso principal Preliminar afastada. RECONVENÇÃO Suposta propaganda indevida Ausência de conotação comercial - Uso da propriedade de acordo com sua função social, defesa do princípio econômico da livre concorrência e os direitos de garantia e proteção ao consumidor que devem ser considerados - Panfleto, no mais, que não é enganoso nem denegriu os produtos da concorrente - Conteúdo dos informativos a que teve acesso a autora-reconvinda que não são confidenciais Ausência, aliás, de prova de que tenham sido obtidos por meios ilícitos ou mediante fraude Recurso da ré não provido. ${ }^{565}$

Comentários: Aqui, ficou decidido que o uso da marca de concorrente em panfleto que se destinava à informação aos funcionários e distribuidores não continha conotação comercial. Note-se ainda que o julgado foi claro ao afirmar que o caráter informativo não denigre a marca do concorrente, em que pese o posicionamento de Celso DELMANTO e Hermano DUVAL.

Ementa: PUBLICIDADE. PROPAGANDA COMPARATIVA. CHUVEIRO ELETRICO. UTILIZACAO DE UM MODELO FACILMENTE IDENTIFICAVEL COM O CHUVEIRO ELETRICO PRODUZIDO PELA LORENZETTI, EM COMPARACAO COM O AQUECEDOR A GAS FABRICADO PELA RE, COM O PRO - POSITO DE DEPRECIA-LO JUNTO

\footnotetext{
${ }^{564}$ TJSP. Ap. Cív. no 0007039-47.2010.8.26.0568. : 2ª Câmara Reservada de Direito Empresarial. Rel. Des. Roberto Mac Cracken. Data do julgamento: 29/05/2012.

${ }^{565}$ TJSP. Ap. Cív. no 9113494-40.2007.8.26.0000. $1^{\text {a }}$ Câmara de Direito Privado. Rel: Des. De Santi Ribeiro. Data do julgamento: 07/02/2012.
} 


\section{AO PUBLICO CONSUMIDOR. PROPAGANDA COMPARATIVA INACEITAVEL. ${ }^{566}$}

Comentários: O Tribunal entendeu que a propaganda da ré não atendia ao disposto do artigo 32 alínea a do Código de Autorregulamentação Publicitária, que rege o direito à informação. De acordo com o julgado, também houve denegrimento da marca da concorrente (autor) por fazer menção à possível característica não comprovada do produto (o produto do concorrente, uma ducha de banho, foi taxado de pinga-pinga).

Por todo o acima, é preciso analisar com cuidado a questão da publicidade comparativa haja vista as nuances encontradas na legislação e na jurisprudência administrativa e judicial. Os valores da livre iniciativa e da liberdade de concorrência estão muito presentes na vida comercial do país, principalmente por serem garantias constitucionais. Dessa forma, provável que, em que pese o direito de uso exclusivo obtido pelos titulares de marca, a prática da publicidade comparativa lícita continue a evoluir, sedimentando seu posicionamento frente ao direito de propriedade.

${ }^{566}$ TJRS. Ap. Cív. no 591051560. Quinta Câmara Cível. Rel. Des. Ruy Rosado de Aguiar Júnior. Data do julgamento: 22/08/1991. 


\section{Conclusões}

O objetivo do presente estudo era demonstrar que o direito de uso sobre a marca, registrada ou não, é capaz de gerar consequências positivas e negativas à mesma e ao seu titular. Para isso, escolheu-se como foco a busca pelo entendimento sobre a integridade material da marca e a integridade moral do seu titular. A LPI, outorgada em 1996, trouxe como novidade o direito ao depositante da marca e ao titular do registro de zelarem pela integridade da marca ou sua reputação.

Os institutos mais importantes do Direito Real foram apresentados de modo a oferecer uma visão ampliada da constituição dos direitos reais e das interseções que existem entre esse ramo do Direito Civil com o direito das marcas. Por muito tempo e até os dias de hoje, paralelos entre os dois ramos do Direito são estudados, inclusive emprestando certos conceitos aos recentes direitos intelectuais. Nessa linha, PICARD, no fim do século XVIII, foi quem primeiro trouxe a noção inovadora de se considerar os direitos intelectuais como um quarto grupo de relações jurídicas, diferente do proposto pelo Direito Romano que não aceitava a hipótese de haver relação entre pessoa e bens intangíveis.

Muito tempo depois, os direitos sobre bens intangíveis foram alçados ao nível de direito de propriedade munido de um feixe bem determinado de direitos sobre a res incorporales. Assim é que, internacionalmente, o direito sobre a marca foi encarado como direito de propriedade. Não diferente, as legislações nacionais, desde o fim do século XIX, seguiram a mesma tendência. Ainda hoje, o direito de propriedade sobre a marca é recebido pela $\mathrm{CF} / 88$, em seu artigo $5^{\circ}$ inciso XIX. Tal interpretação abre margem a outras. Os bens intelectuais são passíveis de aquisição de propriedade pelo uso? Como se verificou no estudo, os principais doutrinadores civilistas não afastam essa possibilidade, a qual inclusive teve repercussão em nossos tribunais, tanto em interpretações análogas (direito de uso sobre linhas telefônicas) como em interpretações diretas (possibilidade de uso de interditos proibitórios para salvaguardar direitos intelectuais).

Inevitável, portanto, tentar-se alinhar os direitos reais aos direitos intelectuais. Pela característica da ubiquidade, as marcas podem estar na posse de mais de uma pessoa quando do seu uso simultâneo. O Direito Civil chama isso de composse. Hoje, também se 
discute a possibilidade de constituição de titularidade múltipla de marcas, o chamado condomínio de marcas. O INPI ainda não aceita essa ideia, mas já há discussões internas a esse respeito.

Muitas críticas são direcionadas à natureza jurídica de propriedade sobre marcas. Corroborando com elas, é necessário aceitar que as marcas, enquanto bens intelectuais, possuem peculiaridades que lhes são próprias e são impossíveis de serem aplicadas à propriedade material. Enquanto propriedade resolúvel, a marca tem validade, apesar do direito do seu titular em prorrogar essa validade por iguais e subsequentes períodos até persista o interesse em usá-la. Outrossim, o direito de uso exclusivo sobre a marca é limitado à área de atuação do seu titular. Talvez, as marcas de alto renome sejam as que mais cheguem próximo de se estabelecer uma propriedade de marca. Ainda existem críticas sobre os procedimentos instaurados pelo INPI sobre o direito de dispor da marca. Todavia, regras também são impostas para a transferência de bens materiais. Com tudo isso em vista, a doutrina mais recente tem se inclinado a retornar à proposta de PICARD, a de aceitação das particularidades sui generis que cada bem intelectual e assim, os aceitar como são: diferentes da propriedade civil e próprios em sua natureza.

Mas, da mesma forma que uma propriedade, se esbulhada e a posse, turbada parcialmente, a mesma deixa de exercer plenamente todas as suas funções. Por hipótese, imagine-se que um rio de um terreno rural seja desviado por um turbador e isso atrapalhe que os animais daquela propriedade sobrevivam por falta de água. Tem-se aqui o típico problema de ameaça à integridade funcional da referida propriedade.

Do mesmo jeito, havendo uso indevido de marca ou uso incorreto ensejador de prejuízo, causar-se-á efeitos positivos ou negativos na integridade da mesma.

A doutrina tem se concentrado a estudar a integridade da marca somente no que tange aos perigos da diluição da mesma. Tecnicamente, diluição é termo extraído da realidade americana e aplicado ao fenômeno do desgaste distintivo de marcas famosas. Inclusive, o direito americano possui legislação própria nesse sentido - o Trademark Anti Dilution Act. Só que, como ficou demonstrado no estudo aqui proposto, essa leitura apresenta-se obtusa em relação à ampla aplicação do termo integridade à capacidade de exercer em relação a um instituto como a marca. 
Como se viu, integridade está relacionada à inteireza das coisas, à plenitude, à unidade. Integridade também está relacionada ao estado inteiro das coisas; completo. Moralmente, integridade também é um valor ético para os indivíduos e para os concorrentes. Nesse esquema, alinham-se esses significados à marca no sentido de defender que a sua integridade tem de ver com a sua completude de poderes, ou sua plena capacidade de exercer suas características tanto em relação ao seu titular como também perante terceiros.

Dessa forma é que, destrinchando os principais componentes da marca - a distintividade e a distinção, precisam estar intactos para que uma marca seja chamada de íntegra. A distintividade, instituto que aplica-se à capacidade intrínseca da marca de distinguir produtos ou serviços, tem que existir para que qualquer signo seja considerado registrável como marca. Do mesmo jeito, a distinção - solução apresentada que propugna o fim dos erros de terminologia causados pelo costume de utilização de um mesmo termo para qualquer espécie de distintividade - é quem guarda a distância distintiva suficiente para que uma marca seja considerada distinta das demais já registradas ou solicitadas por concorrentes.

SCHECHTER foi o autor mais feliz ao defender a proteção da integridade da marca. Em 1927, ele já expressava preocupação pela tutela da unicidade (é como os doutrinadores têm traduzido o termo uniqueness). Na visão dele, a defesa da unicidade da marca deveria ser o único campo de proteção que um signo distintivo deveria ter. Mesmo sabendo que na primeira metade do século XX, não havia a corrida desenfreada de proteção de marcas no mundo que há hoje, a preocupação de SCHECHTER é digna de celebração.

A integridade da marca consiste na capacidade total em distinguir, de se manter única em seu mercado específico. A marca, quando íntegra, emite um único brilho ao consumidor de modo que este tenha ínfima chance de se confundir no ato da sua escolha.

Conceituou-se distintividade à luz do que rege o artigo 124, inciso VI da LPI e demonstrou-se como esse instituto é avaliado pelos examinadores de marcas do INPI, quando da aplicação das apostilas durante a decisão de deferimento de um pedido de 
registro de marca. As apostilas nada mais são do que ressalvas sobre a falta de distintividade de elementos considerados irregistráveis per se. Muito se tem errado e muitas injustiças vêm sendo cometidas.

A doutrina estuda as forças distintivas de cada marca e as separa de acordo com a sua distinvidade, e por que não, integridade. Ou seja, quanto mais distintiva a marca for, mais forte ela será. Pelo presente estudo, maior será sua integridade material, pois se e quando um terceiro quiser utilizar indevidamente uma marca arbitrária ou fantasiosa, maior probabilidade de sucesso terá o titular prejudicado em cessar o uso indevido, tendo em vista a maior distância distintiva existente entre as marcas do mesmo mercado competidor.

Quando esse brilho único; essa inteireza é erodida pelo uso da marca tanto por seu titular ou por terceiros desautorizados, a sua integridade é abalada; diminuída. De outro turno, quando o titular usa a marca e aufere resultados positivos em relação à sua integridade, percebe-se que a marca evolui em relação à sua força distintiva.

A Semiótica tem estudado esses fenômenos de perto, já que ela é responsável pela análise linguística das expressões culturais dos povos. Apesar da sua vocação distinta da do direito das marcas, a Semiótica muito contribui para o estudo das metamorfoses linguísticas que as marcas experimentam com o uso. Não à toa escolheu-se nomear um dos capítulos de "Os caminhos da distintividade", que nada mais é do que uma homenagem à Semiótica por sua colaboração ao estudo das marcas. O termo "caminhos" denota essas transformações linguísticas, positivas ou negativas, que um signo, distintivo ou não, pode enfrentar.

Quando o caminho (uso) leva a marca para a diminuição de sua integridade, dois resultados são alcançados: a vulgarização ou o desgaste de sua força distintiva. Quando o caminho leva a marca ao aumento de sua integridade, outros dois resultados são percebidos pela doutrina e jurisprudência: o secondary meaning e a notoriedade.

O processo de vulgarização ou degenerescência de marcas pode e deve ser interpretado sob a ótica da integridade. Muitas vezes, é causado pelo próprio titular, seja por omissão ou por ação indevida. Diversas marcas já foram perdidas para o domínio comum porque, por um período de tempo e sem reação contrária dos seus titulares, foram 
utilizadas como gêneros do próprio produto ou serviço designado por elas. São os casos das agora ex-marcas FORMICA, CELOPHANE, CATUPIRY, ASPIRINA entre tantas outras. Note-se que todas as marcas vulgarizadas já foram famosas.

Em caminho inverso, tem-se que palavras ou imagens descritivas, genéricas ou de uso comum são capazes de alcançar certo nível de distintividade, adquirindo integridade material mínima para serem consideradas marcas propriamente ditas. O fenômeno do secondary meaning é um processo lento de percepção pelo consumidor de que determinado elemento de uso comum passa a exercer um brilho próprio para uma palavra considerada res communis omnium. Essa experiência, na visão da clientela, faz nascer uma marca com todas as suas características e capacidades de fazer valer seus efeitos perante terceiros. São os casos das marcas POLVILHO ANTISSÉPTICO e CULTURA INGLESA. Esta, apesar de ter sido considerada de uso comum pelo Judiciário, guarda afetiva lembrança desse autor, e assim, é mantida no rol de expressões instrinsecamente irregistráveis, mas capazes de manifestar seu brilho próprio frente aos seus concorrentes. Aliás, verdade seja dita, não existem muitas marcas de cursos de idiomas que se assemelhem à marca da "CULTURA", tamanha é sua integridade material após décadas de serviços e aceitação no mercado.

Os fenômenos da vulgarização e secondary meaning possuem em comum a interpretação do coeficiente de distintividade. Já nos processos de notoriedade e de desgaste do poder de distinguir, as marcas são interpretadas sob a ótica da distinção.

Em sendo disponível e distintiva dentro da atividade empresarial desejada, a marca pode ser registrada por seus interessados, obedecendo-se o procedimento administrativo do INPI. Mesmo a marca mais ordinária possui sua integridade assim que nasce. Esta encontra proteção nos limites da atuação empresarial do seu titular. Em alguns casos, a especialidade das atividades do titular se relaciona com outras, estendendo limitadamente essa proteção.

Conforme a marca ordinária é utilizada por seu titular ou por terceiros autorizados e em um caminho virtuoso sucesso empresarial, ela avança no conhecimento pelo público consumidor e dependendo da qualidade dos produtos/serviços, possibilita a repetição da experiência do consumo. Inevitável dizer que esses fatores levam a marca à fama e com isso, ao aumento de sua integridade material. 
As marcas famosas merecem especial atenção da teoria da integridade, levando-se em consideração os investimentos realizados por seus titulares e pela presunção de qualidade instaurada no mercado. Essa fama faz da marca um signo desejado por muitos e dessa forma, sua integridade é fortalecida, seduzindo usurpadores e aproveitadores parasitários a copiá-las.

A legislação de 1883 classifica a marca famosa como marca notoriamente conhecida e de acordo com o que ficou demonstrado, a comunidade internacional desenvolveu um sistema de proteção dessas marcas famosas que circulavam internacionalmente, tutelando-as independentemente de registro. A revisão de Estocolmo da CUP estabeleceu que a notoriedade da marca objeto do artigo 6 bis precisa ser atestada no país onde a eventual usurpação ocorre, sob pena de se privilegiar marcas estrangeiras sem registro no território da discussão. Muito se debateu sobre esse ponto e não era difícil encontrar titulares que defendiam suas marcas "famosas" com documentos que atestavam certa fama fora do país.

Quando a marca notoriamente conhecida continua a evoluir no imaginário do público consumidor e passa a reinar sozinha até mesmo fora das atividades comerciais de seu titular, ela torna-se candidata ao status de alto renome, instituído pelo artigo 125 da LPI. Marcas como COCA-COLA, PIRELLI e MCDONALD'S são assim consideradas em virtude do intenso brilho manifestado dentro e fora de seus mercados originais. É forçoso concluir que a integridade material de marcas como essas é tão grande que seria necessária a implementação de meios mais eficazes de sua proteção.

O fato é que a notoriedade também traz efeitos negativos ao titular e à marca. É a "patologia da fama". Quanto mais famosa, mais atenção a marca atrai e com isso, inevitavelmente free riders tentam se aproveitar dessa fama, ou utilizando indevidamente a marca famosa ou registrando marcas fora do alcance da concorrência, ocasionando o parasitismo. Alguns doutrinadores chamam esse fenômeno de "concorrência sem concorrência". Esse parasitismo gera a perda do valor de venda da marca famosa, contribuindo para a sua diluição. A diluição ocorre quando há o uso da marca famosa por mais de um agente econômico, simultaneamente, mas fora do âmbito de proteção da 
atividade comercial original da marca famosa. Diluindo o brilho intenso da marca famosa entre outras origens distintas, há a perda da distinção.

De acordo com a doutrina americana, a diluição da marca pode ocorrer principalmente de duas maneiras: por maculação ou ofuscação. A maculação constitui uma ofensa à integridade material de uma marca. É a conduta que associa, por exemplo, uma marca famosa a um produto ou serviço de baixa qualidade, seja pela sugestão de um vínculo do sinal com um conceito moralmente reprovado pela sociedade. O leading case se refere ao uso do slogan "Enjoy cocaine” com apresentação visual da COCA-COLA. A ofuscação, por sua vez, consiste na perda do brilho distintivo de uma marca. É entendida como uma violação à unicidade do sinal, a partir do momento em que uma mesma expressão passa a identificar produtos de fontes diversas. Em ambos os casos, a diluição do poder distintivo de um signo afeta a integridade material do mesmo.

O abalo negativo da integridade da marca também ocorre quando, principalmente por força do INPI e com menos força, pela inação dos titulares de marca, a distância distintiva entre marcas distintivas per se diminui gradativamente com o deferimento de marcas semelhantes umas às outras dentro de uma mesma categoria ou em categorias afins. Apesar do peso da análise recair sobre o INPI e os titulares, a teoria da distância é interpretada precipuamente sob a perspectiva do consumidor, pois ele é quem decide quando a distância distintiva entre marcas parecidas não o afetará no momento de sua decisão de escolha. A doutrina alemã trata do assunto em um momento pos factum, ou seja aplica-se a teoria após certa convivência de marcas parecidas em um mesmo mercado. De acordo com a doutrina, uma marca sênior tem apenas a amplitude de proteção em face à marca júnior equivalente à mesma distância que aquela mantém em face das marcas similares de outros competidores.

Ainda sobre os efeitos do uso da marca em sua integridade, é preciso notar que o próprio titular pode sofrer abalo em sua confiança perante o mercado. Sua reputação pode ruir dependendo dos efeitos nefastos de utilização de sua marca por terceiros. O uso denegritório é condenável e certamente, remédios jurídicos existem para que os titulares de marca evitem que isso se perpetue, garantindo o direito de zelo de reputação. 
Contra todos os efeitos negativos gerados pelo uso, seja pelos próprios titulares ou por terceiros, é possível que os interessados intentem medidas de proteção da integridade material de suas marcas. Todavia, tais direitos não são absolutos. O direito constitucional de liberdade de expressão garante ao cidadão a livre faculdade de expor seus sentimentos, desprazeres ou experiências vividas. Logo, as marcas não estão livres de serem criticadas, desde que tais críticas tenham o cunho de exteriorização de opiniões de boa-fé. Qualquer expressão que tenha somente o interesse denegritório é desaprovada pela lei.

$\mathrm{Na}$ mesma linha, a publicidade comparativa, amparada pelo direito constitucional de livre iniciativa e pelo regulamento administrativo do CONAR, é permitida obedecendo-se uma série de requisitos. A preocupação é pelo fato da publicidade constituir uma atividade comercial e por sua natureza, qualquer uso de marca de terceiro em uma propaganda possui cunho econômico. Do contrário, para quê comparar? A ideia original da publicidade é sempre de enaltecimento do produto/serviço vendido. A LPI foi menos permissiva nesse sentido, tendo proibido qualquer uso de marca de terceiro com conotação comercial. Objetivamente, havendo comparação entre produtos de marcas concorrentes e havendo um vencedor, o perdedor sofrerá abalo em sua integridade material, pois seu poder de venda diminui.

Entretanto, não há como deixar de comentar que o consumidor pode ser o grande vitorioso com as propagandas comparativas, pois obedecendo-se os preceitos do CONAR e da boa-fé, leva-se mais informação à população gerando oportunidade para uma melhor decisão de compra. E por via de consequência, o perdedor reagirá melhorando seus produtos objetivando a reconquista da integridade material de sua marca. 


\section{REFERÊNCIAS BIBLIOGRÁFICAS}

ALMEIDA, Liliane do Espírito Santo Roriz. A distintividade como uma função dinâmica da marca: o registro marcário, a degenerescência e o significado secundário". In: XXVI Seminário Nacional da Propriedade Intelectual. Anais 2006. ABPI: Rio de Janeiro, 2007.

ARAÚJO, Fernando. A Tragédia dos Baldios e dos Anti-Baldios - O Problema Econômico do Nível Óptimo de Apropriação. Portugal: Almedina, 2008.

ASCARELLI, Tullio. Teoria della concorrenza e dei beni imateriali. Milão: Giuffrè, 1960.

In tema di caduta del marchio in dominio publico. In: Studi in tema di contrati. Milão: Giuffrè, 1952.

ASCENSÃO, José de Oliveira. Direitos reais. $2^{\text {a }}$ ed. Lisboa: Faculdade de Direito da Universidade de Lisboa, 1973.

As funções da marca e os descritores (Metatags) na Internet. In: RABPI. v. 61. pp. 44-52. Rio de Janeiro: ABPI, 2002.

Direito intelectual, exclusivo e liberdade. In: RABPI v. 59, pp. 40-49. Rio de Janeiro: ABPI, jul/ago 2002.

ASSAFIM, João Marcelo de Lima. A transferência de tecnologia no Brasil. Aspectos contratuais e concorrenciais da propriedade industrial. Rio de Janeiro: Lumen Juris, 2005.

BARBOSA, Cláudio Roberto. Propriedade Intelectual. Introdução à propriedade intelectual como informação. São Paulo: Campus Jurídicos, 2009.

BARBOSA, Denis Borges. Da aplicação da regra da especialidade aos nomes de empresa. Disponível em http://www.denisbarbosa.addr.com/arquivos/novidades/especialidadeaosnomes.pdf. Acessado em 10/08/2012. 
Doutrina da Concorrência PI(2). Disponível em http://www.denisbarbosa.addr.com\%2Farquivos \%2Fapostilas\%2Fpuc\%2FDoutrina $\% 2520$ da\%2520Concorrencia.ppt\&ei=HD2IUN7NH4To9AS25ICoAQ\&usg=AFQjCNHwPjChT B7GIJRm-1FNUHEVwvu9kg. Acesso em 15/11/2012.

Marca: a mais importante das propriedades intelectuais. Disponível em http://www.denisbarbosa.addr.com/104.doc. Acesso em 29/10/2010.

Nota sobre a categoria constitucional da "propriedade das marcas. Disponível em http://denisbarbosa.addr.com/notamarca2.pdf. Acesso em 02 de abril de 2011.

O direito constitucional dos signos distintivos. In: JABUR, Wilson Pinheiro; SANTOS, Manoel J. Pereira dos (Orgs.). Propriedade Intelectual: sinais distintivos e tutela judicial e administrativa. São Paulo: Saraiva, 2007.

. Proteção das Marcas. Uma perspectiva semiológica. Rio de Janeiro: Lumen Juris, 2008.

. Uma Introdução à Propriedade Intelectual. $2^{\mathrm{a}}$ ed. Rio de Janeiro: Lumen Juris, 2003.

BARRETT, Margreth. Intellectual Property: cases and materials. $2^{\mathrm{a}}$ ed. St. Paul: West Publishing, 2001.

BEEBE, Barton: The semiotic analysis of trademark Law. In: UCLA Law Review v. 51. 2004.

BEVILÁQUA, Clóvis. Teoria Geral do Direito Civil: São Paulo: Servanda, 2007.

BITTAR, Carlos Alberto. Direito de Autor na Obra Publicitária. $1^{\text {a }}$ ed. São Paulo: RT, 1981.

BITTAR, Carlos Alberto e BITTAR FILHO, Carlos Alberto. Tutela dos direitos da personalidade e dos Direitos Autorais nas Atividades Empresariais. São Paulo: RT, 1993. 
BODENHAUSEN, G.H.C. Guide to the application of the Paris Convention for the protection of industrial property: as revised at Stockholm in 1967. Genebra: WIPO, 1991 (reimpressão).

CABRAL, Filipe Fonteles. Diluição de marca: Uma Teoria Defensiva ou Ofensiva? In: RABPI v. 58, maio/junho 2002.

CERQUEIRA, João da Gama. Caducidade no registro de marca. São Paulo: Revista dos Tribunais, 1984.

Tratado da Propriedade Industrial. $3^{\mathrm{a}}$ ed. rev. por Denis Borges Barbosa e Newton Silveira. Rio de Janeiro: Lumen Juris, 2010.

Privilégios de invenção e marcas de fabrica e de commercio. Commentario ao Decreto n. 16.294, de 19 de dezembro de 1923. São Paulo: Revista dos Tribunaes, 1931.

CHAVANNE, Albert e BURST Jean-Jacques. Droit de La propriété industrielle. $5^{\mathrm{a}}$ ed. Paris: Dalloz, 1998.

CHINELlato, Silmara: Direitos de Autor e de Personalidade: Reflexões à luz do Código Civil. Tese de Titularidade para a cadeira de Direito Civil da Faculdade de Direito da Universidade de São Paulo. São Paulo: USP, 2008.

CORREA, José Antonio B. L. Faria. A dimensão plurissensorial das marcas: a proteção da marca sonora na lei brasileira. In RABPI, v. 69, mar/abr 2004.

Algumas reflexões sobre a teoria da distância e a teoria da diluição. In: RABPI v. 100. Rio de Janeiro: ABPI, mai/jun 2009.

A proteção da criação intelectual conforme o objeto da obra. In: RABPI v. 64. Rio de Janeiro: ABPI, mai/jun 2003.

. O conceito de uso de marca. In: RABPI v. 16. Rio de Janeiro, maio/junho de 1995.

. O fenômeno da diluição e o conflito de marcas. In: RABPI v. 37. Rio de Janeiro: ABPI, nov/dez 1998. 
. O Tratamento das Marcas de Alto Renome e das Marcas Notoriamente Conhecidas na Lei 9.279/96. In RABPI v. 28, maio/junho 1997.

. Sinais não registráveis. In: JABUR, Wilson Pinheiro Manuel e SANTOS,

Manoel J. Pereira dos (Orgs.). Propriedade Intelectual: Sinais Distintivos e Tutela Judicial e Administrativa. p. 209-266. São Paulo: Saraiva, 2007.

COASE, Ronald H. The problem of social costs. In: Journal of Law and Economics, v. 3, $\mathrm{n}^{\circ} 1: 1-44,1960$.

COSTELLA, Antônio. Direito das Comunicações. São Paulo: RT, 1976.

DANNEMANN. Comentários à Lei da Propriedade Industrial e Correlatos. Renovar: Rio de Janeiro, 2005.

DELMANTO, Celso: Crimes de Concorrência Desleal. São Paulo: Universidade de São Paulo, 1975.

DEMSETZ, Harold. Toward a Theory of Property Rights. In: The American Economic Review, vol.57, $\mathrm{n}^{\circ}$ 2, pp. 347-359. Papers and Proceedings of the Seventy-ninth Annual Meeting of the American Economic Association, 1967.

DI FRANCO, Luigi. Proprietà Industriale, Letteraria ed Artistica. Milão: SEL, 1928.

DOMINGUES, Douglas Gabriel. Comentários à Lei da Propriedade Industrial. Rio de Janeiro: Forense, 2009.

DOTTI, René Ariel. Proteção da vida privada e liberdade de informação. São Paulo: RT, 1980.

DUVAL, Hermano. Concorrência desleal. São Paulo: Saraiva, 1976.

ECO, Umberto. O signo. 6ª Ed. Editorial Presença: Bacarena-PT, 2004.

ECONOMIDES, Nicholas S. The economics of trademarks. In: The Trademark Reporter v. 78, Nova Iorque: INTA, 1988.

FEKETE, Elisabeth Kasznar. O regime jurídico do segredo de indústria e comércio no Direito brasileiro. Rio de Janeiro: Forense, 2003. 
FERNANDEZ-NOVOA, Carlos. Fundamentos del derecho de marcas, Madri: Montecorvo, 1984.

FERRAZ JUNIOR, Tércio Sampaio: Propriedade Industrial e Defesa da Concorrência. In RABPI v. 8. Rio de Janeiro, 1993.

FERREIRA, Aurélio Buarque de Hollanda. Novo Dicionário Aurélio da Língua Portuguesa. $2^{\text {a }}$ ed. Rio de Janeiro: Nova Fronteira, 1997.

FRANCESCHELLI, Remo: Sui marchi di impresa. $4^{\text {a }}$ edição atual. Milão: Giuffrè, 1988.

FRANÇA, R. Limongi. Instituições de Direito Civil. $5^{\text {a }}$ ed. rev. e atual. São Paulo: Saraiva, 1999.

FRÓES, Carlos Henrique de Carvalho: Marca. Aquisição de distintividade e degenerescência. In: JABUR, Wilson Pinheiro; SANTOS, Manoel J. Pereira dos (Orgs.). Propriedade Intelectual: sinais distintivos e tutela judicial e administrativa. São Paulo: Saraiva, 2007.

GEIGER, Christophe - Trade Marks and Freedom of Expression - The Proportionality of Criticism. In: International Review of Intellectual Property and Competion Law, v. 38, n.3, 2007, pp. 317/327.

GINSBURG, Jane C.; LITMAN, Jessica; KEVLIN, Mary L. Trademark and unfair Compettion Law. Cases and materials. $4^{\text {th }}$ Edição. Foundation Press. New York, 2007.

GODOY, Claudio Luiz Bueno de. A liberdade de imprensa e os direitos da personalidade. São Paulo: Atlas, 2001.

GOMES, Orlando. Direitos Reais. Autalizado por Humberto Theodoro Júnior. $18^{\text {a }}$ Edição. Rio de Janeiro: Forense, 2002.

GRAU-KUNTZ, Karin: Jusnaturalismo e Propriedade Intelectual. In: RABPI n 100. p. 717.

GUSMÃO, José Roberto. Painel Mudanças introduzidas pelo INPI na análise dos pedidos de registro de marcas e no processamento delas. In: XIV Seminário Nacional da Propriedade Intelectual. Anais 1994. ABPI: Rio de Janeiro, 2003. 
HARDIN, Garrett. The Tragedy of the Commons. In: Science Magazine, vol. 162, $\mathrm{n}^{\circ}$ 3859, págs. 1243-1248, 1968.

HELLER, M. A.: The tragedy of the anticommons. In: Harvard Law Review. 1998.

HOUASSIS, Antônio. Dicionário de Sinônimos e Antônimos Houassis, $2^{\mathrm{a}}$ edição. São Paulo: Publifolha, 2008.

IDRIS, Kamil: A importância do uso de ativos de Propriedade Intelectual. In: RABPI ${ }^{\circ}$ 74, pags. 3-13, Rio de Janeiro: ABPI, jan/fev 2005.

KANT, Immanuel: Doutrina do Direito. Coleção Fundamentos do Direito. Tradução

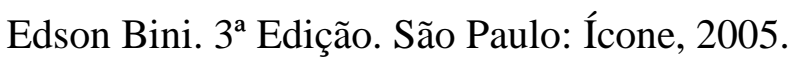

KELLY, David M. and MONDINI, Andrea V: Intend to use it or lose it. In: RABPI v. 24. Rio de Janeiro: ABPI, set/out 2006.

KINNEY \& LANGE P.A. Intellectual Property Law for Business Lawyers. St. Paul: West, 1996.

KOHLER, Joseph. Manualle delle Privative Industriali. Milão: Societá Editrica Libraria, 1914.

JABUR, Wilson Pinheiro. Nomes de domínio. Novo sinal distintivo? In: SANTOS, Manoel J. Pereira dos e JABUR, Wilson Pinheiro (Orgs.). Sinais Distintivos e Tutela Judicial e Administrativa. Série GVLaw. São Paulo: Saraiva, 2007.

LADAS, Steven. Patents, trademarks and related rights: national and international protection. v.2. Cambridge: Harvard University Press, 1975.

LANDES, William M. e POSNER, Richard A. The Economic Structure of Intellectual Property Law. Harvard University Press, 2003.

LEONARDOS, Gabriel. Jurisprudência comentada: o reconhecimento incidental de nulidade de registro de marca. In: RABPI, v. 35, p. 48/51. Rio de Janeiro: jul/ago 1998;

LEONARDOS, Luiz. A proteção das marcas não registradas no Brasil e no Mercosul. In: RABPI. v. 34. pp. 32-35. Rio de Janeiro: ABPI, 1998. 
LOCKE, John. Two Treatises of Government. London, 1689.

MACHADO, Alexandre Fragoso. Uma análise econômica da distintividade das marcas. Trabalho apresentado para a FDUSP no curso Fundamentos do Direito e Economia. Curso de pós-graduação stricto sensu. São Paulo, 2010.

MAILLARD DE MARAFY, Le Cte d. Grand dictionnaire international de la propriété industrielle au point de vue du nom commercial des marques de fabrique et de commerce et de la concurrence déloyale. v. 4 e 5. Paris: Chevalier-Marescq et Cie, 1891.

MARKY, Thomas. Curso elementar de Direito Romano. 6 ${ }^{a}$ ed. São Paulo: Saraiva, 1992.

McCARTHY, J. Thomas; SCHECHTER, Roger E.; FRANKLYN, David J. McCarthy's Desk Encyclopedia of Intellectual Property. Third Edition. Washington: BNA Books, 2004.

MATHÉLY, Paul: Le Noveau Droit Français des Marques. Vélizy Cedex: J.N.A., 1994

MAZZONETTO, Nathalia. A publicidade comparativa e a prática de concorrência desleal por meio do denegrimento de marca e da imagem do concorrente. In RABPI v. 99. Rio de Janeiro: ABPI, , mar/abr 2009. pp. 3/20.

MEDRANO, Gabriel Martinez: Protección contra la dilución marcaria en el Derecho Argentino. In: RABPI v. 75. Rio de Janeiro, mar/abr 2005.

MELlO, Marcos Bernardes de. Teoria do Fato Jurídico. Plano da Existência. $16^{\mathrm{a}}$ ed. São Paulo: Saraiva, 2010.

MENDONÇA, J.X. Carvalho de: Tratado de Direito Comercial Brasileiro, vol. V, livro III, parte I. $5^{\text {a }}$ ed. São Paulo: Freitas Bastos, 1955.

MERLEAU- PONTY, Phénoménologie de la Perception. Paris: Gallimard, 1945.

MILLER, Arthur R.; Davis, Michael H. Intellectual property: patents, trademarks and copyright in a nutshell. $2^{\mathrm{a}}$ ed. St. Paul (EUA): West Publishing, 1990.

MIRANDA, Pontes de. Tratado de Direito Privado - tomos XVI e XVII. Propriedade Intelectual. Propriedade Industrial. v. II. $4^{\text {a }}$ ed. São Paulo: Revista dos Tribunais, 1975. 
MORAES, Alexandre. Constituição do Brasil Interpretada e Legislação Constitucional. São Paulo: Atlas, 2002.

MORO, Maitê Cecília Fabbri. Marcas Tridimensionais. São Paulo: Saraiva, 2009.

MUELLER, Bernardo, ZYLBERSZTAJN, Decio e SZTAJN, Rachel. Economia dos direitos de propriedade. In: ZYLBERSZTAJN, Decio e SZTAJN, Rachel, (Orgs). Direito \& Economia. Análise Econômica do Direito e das Organizações. $2^{\mathrm{a}}$ Tiragem. São Paulo: Campus, 2005.

NAÍM, Moisés: Ilícito. $O$ ataque da pirataria, da lavagem de dinheiro e do tráfico à economia global. Jorge Zahar Editor: Rio de Janeiro, 2006.

OTAMENDI, Jorge. Derecho de marcas. 5ª ed. Buenos Aires: Abeledo-Perrot, 2003.

PAES, P.R. Tavares: Nova Lei da Propriedade Industrial. Lei $\mathbf{n}^{\mathbf{0}}$ 9.279 - 14.05.96. Anotações. Revista dos Tribunais: São Paulo, 1996.

PEIRCE, Charles Sanders. Semiótica. 3ª edição. São Paulo: Perspectiva, 2005.

PEREIRA, Marco Antônio Marcondes. Concorrência desleal por meio da publicidade. São Paulo: Juarez de Oliveira, 2001.

PÉROT-MOREL, Marie-Angèle. L'opposabilité dês antériorités em matière de marque de fabrique, de commerce ou de service. In: Revue Trimestrielle de Droit Commercial, ano 24, v. 2, abr/jun 1971.

PICARD, Edmond. O Direito Puro. 2 ${ }^{\mathrm{a}}$ ed. Progresso: Salvador, 1954.

POUILLET, Eugène. Traité des marques de fabrique et de la concurrence déloyale em tous genres. Paris: Marchal et Billard, 1898.

POULLAND-DULIAN, Fréderic. Droit de La Propriété Industrielle. Paris: Montchrestien, 1999.

RIBEIRO, Ana Carolina Cagnoni. Marcas registradas e liberdade de expressão: o posicionamento americano e o recente dilema europeu. In RABPI v. 110, jan/fev 2011. Rio de Janeiro: ABPI, 2002. pp. 61/68. 
RICCI, Antonio Ferro. O significado secundário da marca. In: XXVI Seminário Nacional da Propriedade Intelectual da ABPI. Anais 2006. Rio de Janeiro: ABPI, 2007.

RODRIGUES, Clóvis Costa. Concorrência desleal, Rio de Janeiro: Peixoto, 1945.

ROTONDI, Mario. Diritto Industriale. Pádua: Cedam, 1965.

ROUBIER, Paul: Le Droit de La Propriété industrielle, Tome I. Paris: Sirey, 1952.

ROUSSEAU, Jean Jacques. Du Contrat Social: ou Príncipes du Droit Politique. França, 1762 .

SACCONI, Luiz Antônio. Grande Dicionário Sacconi da Língua Portugesa Comentado, Crítico e Enciclopédico. São Paulo: Nova geração, 2010.

SAINT-GAL, Yves. Protection et défense des marques de fabrique et concurrence déloyale: droit français et droits étrangers. $5^{\text {a }}$ Ed. Paris: J. Delmas et Cie., 1982.

SAUSSURE, Ferdinand de: Curso de lingüística geral. $4^{\text {a }}$ edição. São Paulo: Cultrix, 1972 .

SCHECHTER, Frank: The rational basis of trademark protection. In: Harvard Law Review, v. 40, n. 6. Cambridge, 1927.

SCHMIDT, Lélio Denícoli. A ação de adjudicação e os direitos de preferência ao registro de marca. In: RABPI. v. 31. p. 03-20. Rio de Janeiro: ABPI, 1997.

A publicidade comparativa à luz da lei de propriedade industrial. In: RABPI v. 52. Rio de Janeiro: ABPI, mai/jun 2001. pp. 3/17.

Marcas em semiótica: secondary meaning, vulgarização e teoria da distância. Dissertação de Mestrado para a PUC-SP. São Paulo: PUC-SP, 2010.

Princípios Aplicáveis aos Sinais Distintivos. In: JABUR, Wilson Pinheiro; SANTOS, Manoel J. Pereira dos (Orgs.). Propriedade Intelectual: sinais distintivos e tutela judicial e administrativa. pp. 31-80. São Paulo: Saraiva, 2007.

SEELIG, Geert W. La théorie de la distance. In: Revue Internationale de la Propriété Industrielle et Artistique, RIPIA nº 62, p. 389. 1965. 
SILVA, De Plácido e. Vocabulário Jurídico. v. 1. 12ª Ed. Rio de Janeiro: Forense, 1993.

SILVA, José Afonso da. Curso de Direito Constitucional Positivo. São Paulo: Malheiros, 2003.

SILVEIRA, Newton. A Propriedade Intelectual e a nova Lei da Propriedade Industrial (Lei no 9.279/1996). São Paulo: Saraiva, 1996.

. Curso de Propriedade Industrial. São Paulo: Revista dos Tribunais, 1987.

. Licença de uso de marca e outros sinais distintivos. São Paulo: Saraiva, 1984

. O Direito de Autor no Desenho Industrial. São Paulo: Revista dos Tribunais, 1982.

. Propriedade Intelectual. Propriedade Industrial. Direito de Autor. Software, Cultivares, Nome Empresarial. $4^{\mathrm{a}}$ ed. revisada e ampliada. São Paulo: Manole, 2010 . Sinais distintivos da empresa. In RABPI v. 98. Rio de Janeiro: ABPI, jan/fev 2009.

e GRAU-KUNTZ, Karin. A exaustão do direito de marcas na União Européia e o Mercosul. In: RABPI. v. 25, pp. 06-22. Rio de Janeiro: ABPI, 1996.

SIERVI, Amanda Fonseca de. Efeitos da notoriedade em relação à distintividade marcaria: secondary meaning e degeneração. Dissertação de Mestrado em Direito Comercial. PUC-SP: São Paulo, 2005.

SOARES, José Carlos Tinoco. Caducidade do registro de marca. São Paulo: Revista dos Tribunais, 1984.

Lei de Patentes, Marcas e Direitos Conexos: Lei 9.279 - 14.05.1996. RT. São Paulo, 1997.

Marcas Notoriamente Conhecidas - Marcas de Alto Renome Vs. Diluição.

Rio de Janeiro: Lumen Juris, 2010. 
. Tratado da Propriedade Industrial. Marcas e congêneres. São Paulo: Jurídica Brasileira, 2003.

Tratado da Propriedade Industrial. Vol. I. São Paulo: Resenha Tributária, 1988.

SZTAJN, Rachel. Teoria Jurídica da Empresa. Atividade empresária e mercados. São Paulo: Atlas, 2004.

TEPEDINO, Gustavo e SCHREIBER, Anderson: A Garantia da Propriedade no Direito Brasileiro. Revista da Faculdade de Direito de Campos. Ano VI, $n^{\circ}$ 6. Rio de Janeiro: FDC, 2005.

TIMM, Luciano Benetti, CAOVILLA, Renato e BRENDLER, Gustavo. As teorias rivais sobre Propriedade Intelectual no Brasil. Disponível no link http://www.escholarship.org/uc/item/3fs9d0m3\#page-1. Acessado em 29 de novembro de 2012.

VENOSA, Sílvio de Salvo. Direito Civil. Direitos Reais. 3ª ed. São Paulo: Atlas, 2003.

VERÇOSA, Haroldo Malheiros Duclerc: Curso de Direito Comercial vol. 1. Teoria Geral do Direito Comercial e das Atividades Empresariais Mercantis. Introdução à Teoria Geral da Concorrência e dos Bens imateriais. $4^{a}$ Edição atualizada e ampliada. São Paulo: Malheiros, 2011.

ZYLBERSZTAJN, Decio e SZTAJN, Rachel (Orgs.). Direito \& Economia. Análise Econômica do Direito e das Organizações. $2^{\text {a }}$ Tiragem. São Paulo: Editora Campus, 2005 . 